63179

\title{
Industrial Change in the Bangkok Urban Region
}

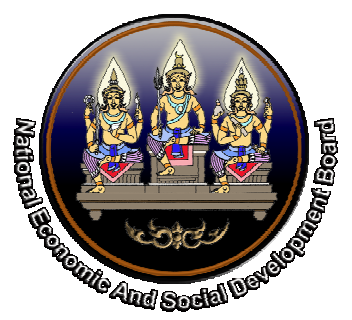

Office of the National Economic and Social Development Board (Thailand)

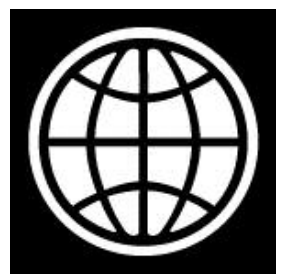

The World Bank 


\section{Table of Contents}

Preface.......................................................................

Executive Summary ............................................................

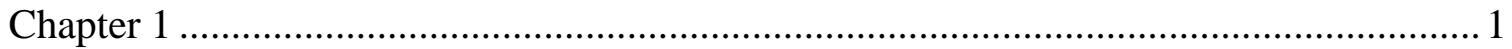

The Making of a Dynamic Urban Region ......................................................... 2

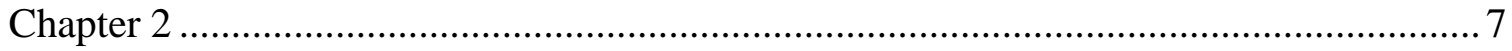

I. Varieties of Industrial Aggregation ................................................................... 8

II. Recent Performance of the Thai Economy …………………................................ 10

III. Comparative Advantage and Diversification Possibilities....................................... 14

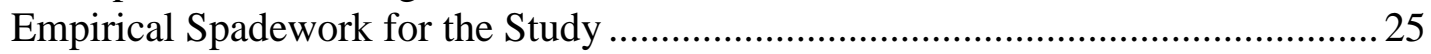

Chapter 3 The Evolution of Industrial Activities in Bangkok ......................................... 27

I. Share of Industrial activities in Bangkok and the vicinity ....................................2

Auto Parts Industry........................................................................................ 30

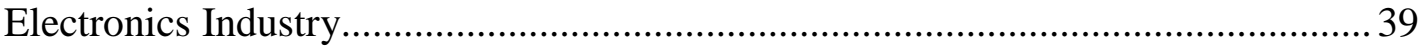

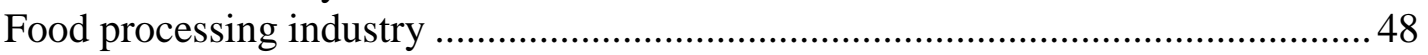

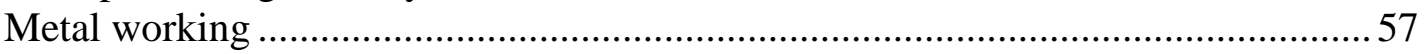

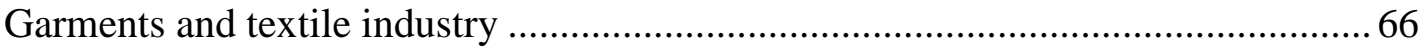

Printing and Publishing Industry ........................................................................ 75

II. Trends in industrial activities in Bangkok and the Vicinity ..................................... 84

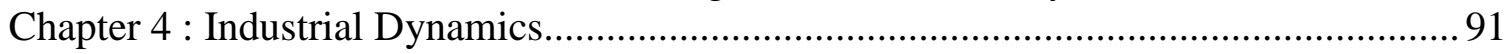

I. Location choice of firms in Bangkok................................................................ 92

II. Availability and Quality of Labor ....................................................................... 98

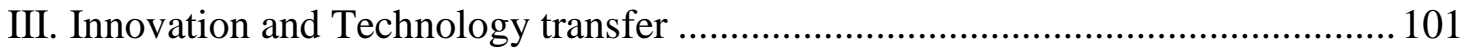

IV. The role of business services in cluster formation............................................ 112

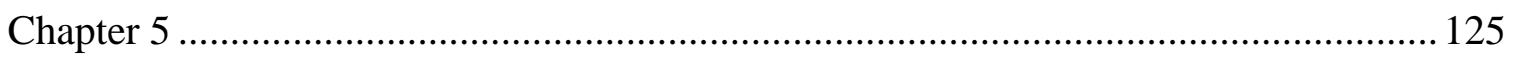

\section{List of Figures}

Figure 1.1: Thailand Real GDP Growth (Annual percent) ...............................................viii

Figure 2.1: Thailand Real GDP Growth (Annual \%) ..................................................... 11

Figure 2.3: Export Composition of Thailand, 1990-2006 ……………………….......... 15

Figure 2.5: Product Space of Thailand, 2006 .............................................................. 19

Figure 2.6: Global Share of Selected Thai Exports......................................................... 24

Figure 2.7: Foreign direct investment, net inflows (BoP, current US\$ billions) .............. 25

Figure 3.1: Number of establishments in auto sectors at province level........................... 32

Figure 3.2: Number of establishments in auto sectors at district level ............................. 33

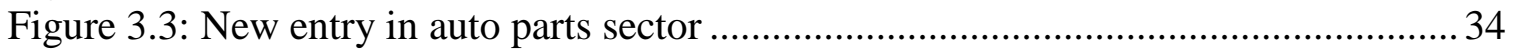

Figure 3.4: Employment in auto parts sector ……………......................................... 35

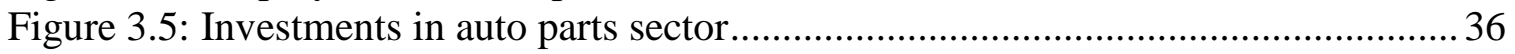

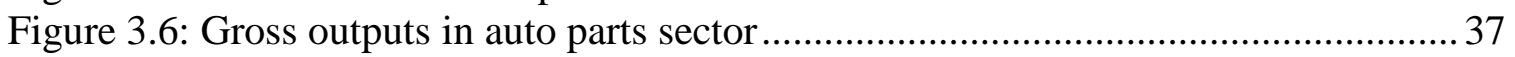

Figure 3.7: Skill composition in auto parts sector............................................................ 38

Figure 3.8: Number of firms in electronics at province level ........................................ 41

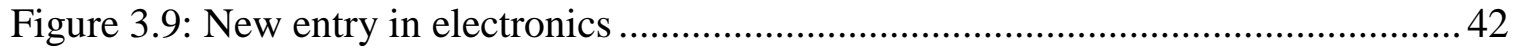

Figure 3.10: Number of firms in electronics at district level .......................................... 43

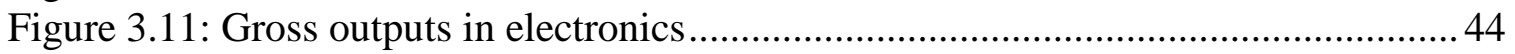

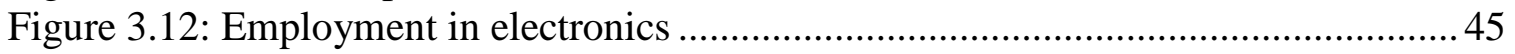

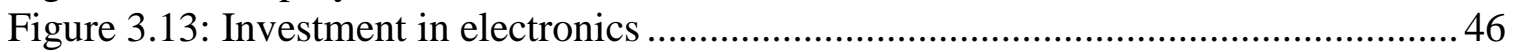




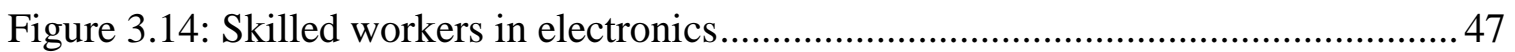

Figure 3.15: Number of firms in food processing industry at province level ...................50

Figure 3.16: Number of firms in food processing industry at district level ......................51

Figure 3.17: Net entry in food processing industry.....................................................52

Figure 3.18: Gross outputs of food processing industry ………...................................5 53

Figure 3.19: Employment in food processing industry ……………….......................... 54

Figure 3.20: Investment in food processing industry ..................................................5

Figure 3.21: Skill composition in food processing industry ……………………….......56

Figure 3.22: Number of establishments in metal working industry at province level ......59

Figure 3.23: Number of establishments in metal working industry at district level .........60

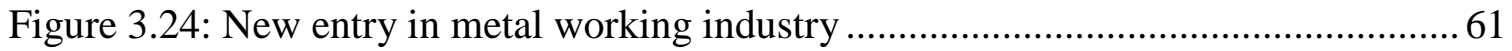

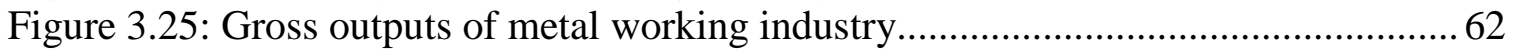

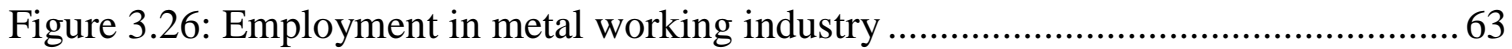

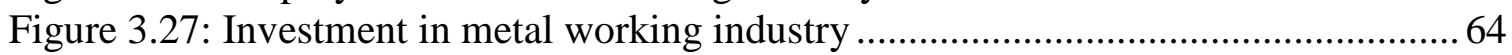

Figure 3.28: Share of skilled worker in metal working industry .....................................65

Figure 3.29: Number of establishments in textile industry at province level ...................68

Figure 3.30: Number of establishments in textile industry at district level ......................69

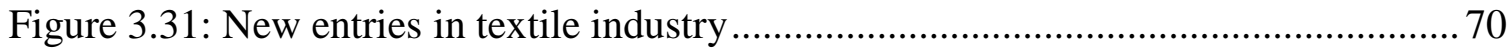

Figure 3.32: Gross outputs of textile industry .......................................................... 71

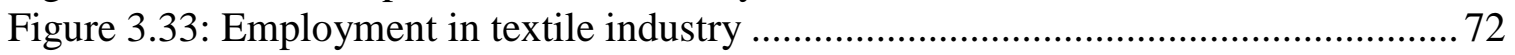

Figure 3.34: Investment in textile industry …………............................................. 73

Figure 3.35: Skill composition in textile industry.................................................... 74

Figure 3.36: Number of establishments in printing and publishing at province level ...... 77

Figure 3.37: Number of establishments in printing and publishing at district level .........78

Figure 3.38: New entries in printing and publishing industry........................................ 79

Figure 3.39: Gross outputs of printing and publishing industry ...................................... 80

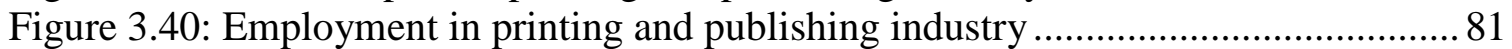

Figure 3.41: Investment in printing and publishing industry ....................................... 82

Figure 3.42: Skill composition in printing and publishing industry ................................. 83

Figure 3.43: Industrial Estates / Industrial Parks / Industrial Zones ................................. 88

Figure 4.1: Reponses to the question, "Are the cost of production, quality and speed of transport facilities to the centre of Bangkok or airports or ports suitable and

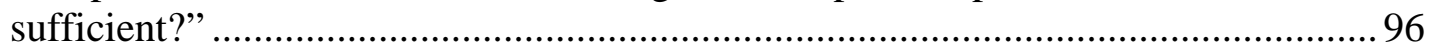

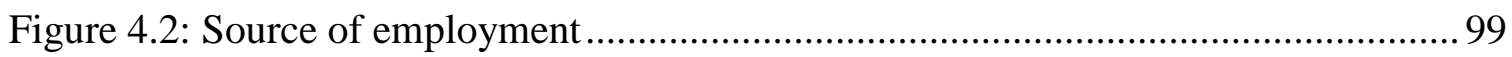

Figure 4.3: Share of innovating companies in Thailand ............................................... 102

Figure 4.4: Proportion of new product introduced in the past 2 and 5 years by industry 102 Figure 4.5: Sources of Product Designs ....................................................................... 103

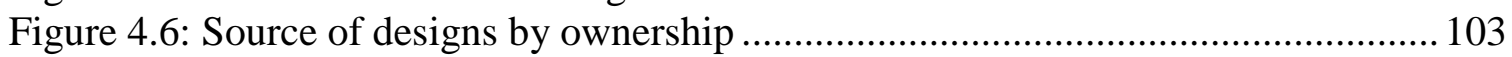

Figure 4.7: Responses by firms on the questions, "Has your company ever designed or upgraded products with customers or suppliers?"................................................... 104

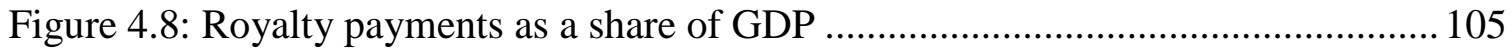

Figure 4.9: Collaboration with customers and/or suppliers by ownership....................... 105

Figure 4.10: External Collaboration for R\&D Activities for 1999-2003 ........................ 109

Figure 4.11: External Collaboration for Product Innovation for Year 1999- 2003......... 109

Figure 4.12: External Collaboration for Process Innovation for Year 1999- 20............. 110 
Figure 4.13: Share of firms seeking technical assistance or research support from universities and research institutes

Figure 4.14: Share of firms that indicated an increase in collaboration with universities and research institutes in the past five years

Figure 4.15: Firms receiving technical assistance from universities or research institutes

Figure 4.16: Number of firms that increased collaboration with universities or research institutes .....

Figure 4.17: The effects of new companies entering in the same locations.

Figure 4.18: The cost and quality of the IT infrastructure that you use for business purpose

Figure 4.19: Internet services availability (per 100 people), 2008

\section{List of Tables}

Table 1.1: Shares of GDP and Manufacturing by Region (2009)................................viii

Table 1.2: Real GDP Growth Rates by Region (percent) ............................................

Table 1.3: Thailand, Shares in GDP (percent) ..........................................................

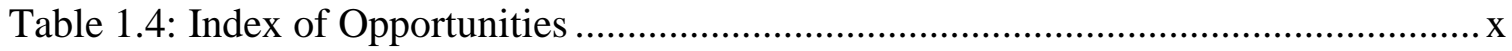

Table 2.1: Thailand, Shares in GDP (\%) .................................................................. 11

Table 2.2: Contribution to GDP Growth by Sector (Demand Side), percentage points ... 13

Table 2.3: Contribution to GDP Growth by Sector (Supply Side), percentage points ..... 13

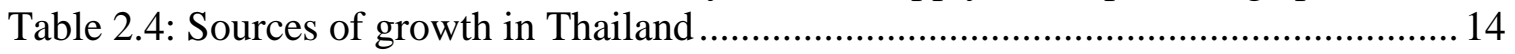

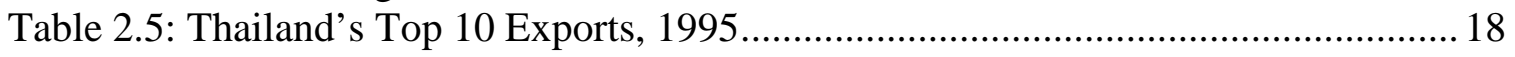

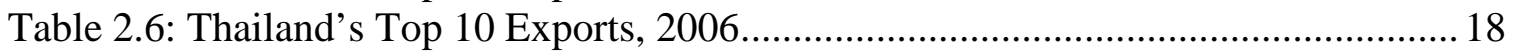

Table 2.7: Top 10 "upscale" commodities with highest density in Thailand, 1995 ......... 20

Table 2.8: Top 10 "upscale" commodities with highest density in Thailand, 2006 ......... 21

Table 2.9: Top 10 fastest growing exports from Thailand, 2000-2007.......................... 23

Table 2.10: Top 10, 4-digit level Commodities with highest RCA in Thailand (1995,

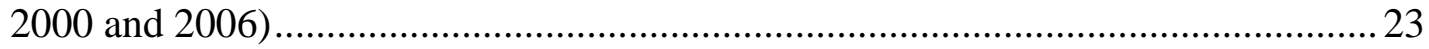

Table 3.1: Bangkok and vicinity's share of national total in manufacturing ................... 27

Table 3.2: Bangkok and vicinity's share of national total in manufacturing, by industrial

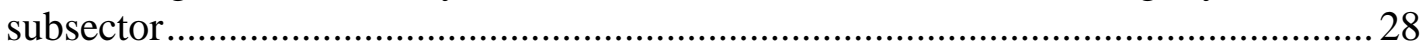

Table 3.3: Labor Productivity in Bangkok ................................................................... 29

Table 3.4: Labor Productivity in the vicinity of Bangkok ............................................ 30

Table 3.5: Changes in Auto Parts Industry, 1997-2007 (values in thousand baht).......... 31

Table 3.6: Changes in Electronics Industry, 1997-2007 (values in thousand baht)......... 40

Table 3.7: Changes in Food Processing Industry, 1997-2007 (values in thousand baht) . 49

Table 3.8: Changes in Metal Industry, 1997-2007 (values in thousand baht) ..................58

Table 3.9: Changes in Textiles Industry, 1997-2007 (values in thousand baht)..............67

Table 3.10: Bangkok and Vicinity Share of National Total in Services ......................... 76

Table 3.11: Changes in Printing and Publishing Industries, 1997-2007 ......................... 76

Table 3.12: Changes in Services Subsectors in Bangkok, 2000-2006 ............................ 85

Table 3.13: Bangkok's shares in selected services sectors, 2006 ................................. 85

Table 3.14: Changes in Services Subsectors in Vicinity, 2000-2006 ............................ 86

Table 3.15: Vicinity's shares in selected services sectors, 2006.................................. 86 


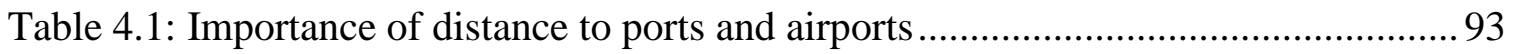

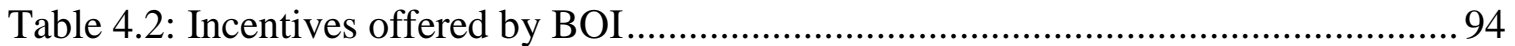

Table 4.3: Locations of companies separated by the nationalities and sizes ...................95

Table 4.4: Advantages of choosing to locate plants inside industrial estate ....................96

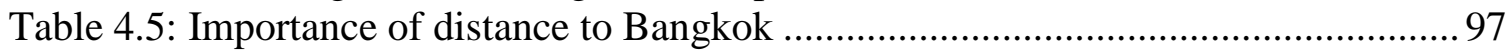

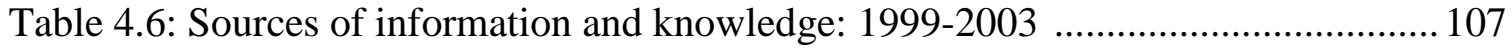

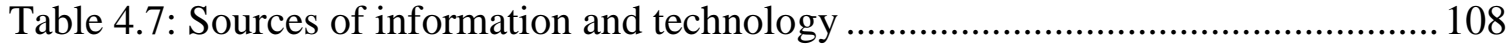

Table 4.8: Proportion of services purchased by factories, sorted by location................. 113

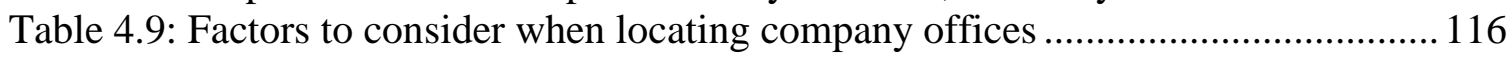

Table 4.10: Proportions of communication channels between factories and business

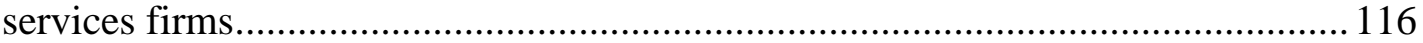

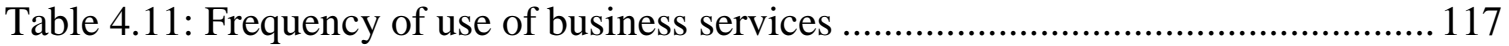

Table 4.12: The core services and new services of each service sector during the last 2

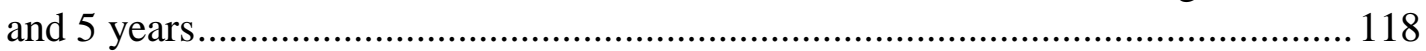

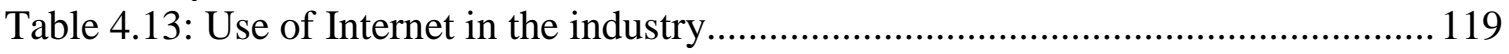

Table 4.14: Types of Internet usage in industrial factories ....................................... 121 


\section{Preface}

The 2009 WDR on economic geography aroused interest among policymakers in Thailand and led to an agreement between the Office of the National Economic and Social Development Board (NESDB) and the East Asia Poverty Reduction and Economic Management Unit of the World Bank to collaborate on a study of the Bangkok urban region which is Thailand's engine of growth.

This report is the fruit of continuous collaboration between the National Economic and Social Development Board (NESDB) and the World Bank. This report was prepared by a joint NESDB-World Bank team. The World Bank team members were Shahid Yusuf (Team Leader), Kaoru Nabeshima, and Kirida Bhaopichitr. The NESDB team comprised of Dr. Jarunun Sutiprapa and her staff at the Spatial Development Department of the NESDB. In addition to investing a substantial amount of staff time, the Spatial Development Department financed the production of the district level Geographical Information Survey based maps as well as a survey of firms and industrial developers (conducted by Dr. Deunden Nikomborirak and the staff of the Thailand Development Research Institute) that provided much of the empirical material for the study.

The teams received the support, guidance and comments from the NESDB Secretary General Arkhom Termpittayapaisith and World Bank Lead Economist, Mathew Verghis. Valuable comments from Zhi Liu, Abha Joshi-Ghani, C. Fallert Kessides, and Federico Gil Sander at the World Bank assisted in the final revision of the report. Rory Birmingham and Lopa Chakraborti processed the data and assisted with the production of multiple drafts. 


\section{Executive Summary}

For over three decades, Thailand has consistently ranked as one of the fastest growing Southeast Asian economies. This growth performance is principally the result of high levels of domestic and foreign investment that enabled Thailand to build a diversified, export oriented industrial economy and absorb technologies from more advanced countries. Much of this industrialization has been concentrated in Bangkok and five adjacent provinces that comprise the Bangkok metropolitan region ${ }^{1}$ and, in recent years, a few provinces further to the south east which are now a part of the Bangkok urban region. ${ }^{2}$ This sprawling region extending from Samut Sakhon to Chonburi and Rayong provinces along the Eastern Seaboard accounts for nearly three fourths of Thailand's GDP (see Table 0.1) and prior to the 2009 crisis the Central and Eastern provinces which include the Bangkok urban region averaged a growth rate of 7.3 per cent p.a., almost 2.5 percent p.a. higher than for the Bangkok metropolitan region (see Table 1.2). The Bangkok urban region is the engine room of the Thai economy, and future national performance is closely tied to its development (Table 0.3).

The principal economic challenge for Thailand is to enhance the industrial potential of the region so as to sustain real GDP growth at between 5 and 6 percent per annum. This is well below the growth rates of 8 and 9 percent per annum achieved during 1985-1995 (Figure 0.1). But given the significant decline in the rate of investment from an average of 30 percent per annum during 1995-2000 to less than 25 percent since, the lower figure is a realistic target (see Table 0.3).

\footnotetext{
${ }^{1}$ The five adjacent provinces are Nonthaburi, Nakhon Pratom, Pathum Thani, Samut Prakarn, and Samut Sakhon.

${ }^{2}$ Vicinity includes the provinces of Chon Buri, Chachoengsao, Nonthaburi, Pra Nakhon Si Ayudhaya, Pathum Thani, Rayong, Samut Prakarn, and Samut Sakhon. The Bangkok metropolitan region includes Samut Prakan, Pathum Thani, Samut Sakhon, Nakhon Pathom and Nonthaburi.
} 
Figure 0.1: Thailand Real GDP Growth (Annual percent)

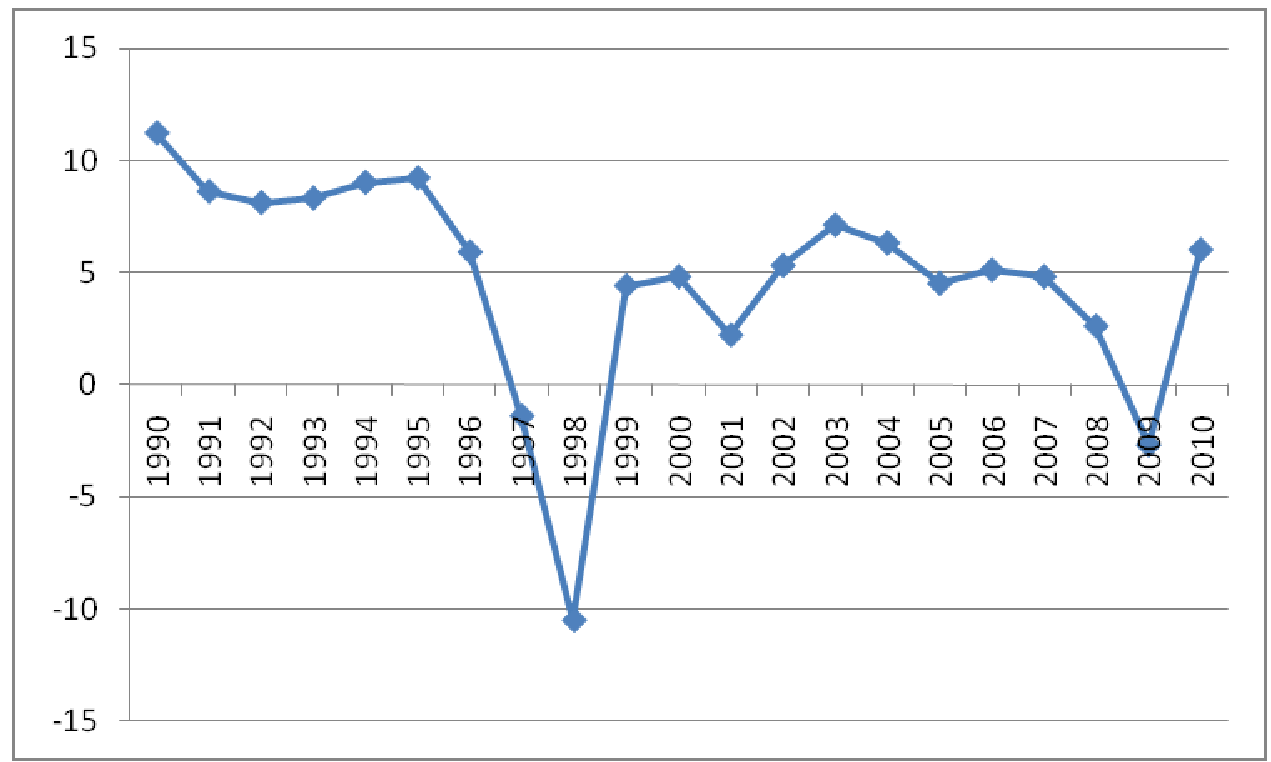

Source: World Development Indicators

Note: The figure for 2010 is a World Bank projection

Table 0.1: Shares of GDP and Manufacturing by Region (2009)

\begin{tabular}{lcc}
\hline & Millions of Baht & Share \\
\hline GDP & & \\
Whole Kingdom & $9,050,715$ & $100 \%$ \\
Bangkok & $2,352,180$ & $26 \%$ \\
Bangkok Metropolitan Region & $3,770,185$ & $42 \%$ \\
Bangkok and Vicinity & $5,246,836$ & $58 \%$ \\
& & \\
Manufacturing & & \\
Whole Kingdom & $3,084,057$ & $100 \%$ \\
Bangkok & 488,268 & $16 \%$ \\
Bangkok Metropolitan Region & $1,465,838$ & $48 \%$ \\
Bangkok and Vicinity & $2,360,546$ & $77 \%$ \\
\hline
\end{tabular}

Source: NESDB

Note: Vicinity includes the provinces of Chon Buri, Chachoengsao, Nonthaburi, Pra Nakhon Si Ayudhaya, Pathum Thani, Rayong, Samut Prakarn, and Samut Sakhon; and the Bangkok metropolitan region includes Samut Prakan, Pathum Thani, Samut Sakhon, Nakhon Pathom and Nonthaburi. 
Table 0.2: Real GDP Growth Rates by Region (percent)

\begin{tabular}{lcccccccc}
\hline & & & & & & & & $\begin{array}{c}2003- \\
2008\end{array}$ \\
& 2003 & 2004 & 2005 & 2006 & 2007 & 2008 & 2009 & Average \\
\hline Whole & & & & & & & & \\
Kingdom & 7.14 & 6.34 & 4.6 & 5.15 & 4.93 & 2.46 & -2.25 & 5.1 \\
Northeast & 7.19 & 2.5 & 1.35 & 8.04 & 5.85 & 2.03 & 2.43 & 4.5 \\
North & 8.34 & 1.34 & 2.07 & 5.46 & 4.91 & 0.84 & 1.73 & 3.8 \\
South & 5.79 & 5.93 & 3.72 & 3.9 & 1.26 & 1.46 & -1.31 & 3.7 \\
Eastern & 10.49 & 10.42 & 5.72 & 5.25 & 5.93 & 3.32 & -5.21 & 6.8 \\
Western & 5.38 & 3.04 & 3.09 & 3.95 & 3.97 & -0.59 & 1.3 & 3.1 \\
Central & 14.84 & 7.6 & 3.93 & 6.75 & 6.71 & 8.88 & -5.99 & 8.1 \\
Bangkok & & & & & & & & \\
Metropolitan & & & & & & & & \\
Region & 4.82 & 6.99 & 5.88 & 4.46 & 4.83 & 1.69 & -2.6 & 4.8 \\
Central and & & & & & & & & \\
Eastern & 12.03 & 9.39 & 5.08 & 5.78 & 6.21 & 5.31 & -5.5 & 7.3 \\
\hline
\end{tabular}

Source: NESDB

Table 0.3: Thailand, Shares in GDP (percent)

\begin{tabular}{lccrc}
\hline & Average & Average & & \\
& $1995-2000$ & 2001-2007 & 2008 & 2009 \\
\hline Gross Fixed Capital Formation & 30.2 & 26.7 & 22.1 & 20.6 \\
Exports of goods and services & 52.2 & 71.7 & 72.5 & 64.2 \\
Imports of goods and services & 47.9 & 66.95 & 57 & 47.0 \\
\hline
\end{tabular}

Source: World Development Indicators; NESDB and WB staff calculations; WB projections for 2009

The Bangkok urban region benefits from agglomeration and scale economies and the scope for further diversification inherent in a broad base of industry and services. An analysis of Thailand's exports mostly sourced from the Bangkok urban region, points to a level of sophistication (EXPY), comparable to that of countries such as China, Poland, and Mexico (see

Table 0.4). Furthermore, a composite index of industrial capability based on multiple indicators of comparative advantage and competitiveness, suggest that Thailand is fourth ranked amongst industrializing countries after China, India and Poland (see 
Table 0.4). In other words, according to these measures, Thailand or more precisely the Bangkok urban region, has gradually built up substantial capabilities in tradable products and services. In order to maintain the pace of development, these capabilities will need to be steadily augmented.

Table 0.4: Index of Opportunities

\begin{tabular}{lccc}
\hline \multirow{2}{*}{ Country } & \multicolumn{2}{c}{ Index of Opportunities } & \multirow{2}{*}{ EXPY } \\
\cline { 2 - 3 } & Rank & Index & \\
\hline China & 1 & 0.9011 & 0.8921 \\
India & 2 & 0.859 & 0.6486 \\
Poland & 3 & 0.7706 & 0.9105 \\
Thailand & 4 & 0.7637 & 0.8703 \\
Mexico & 5 & 0.746 & 0.9689 \\
\hline
\end{tabular}

Source: Felipe, Kumar and Abdon (2010)

The purpose of this study was to examine the dynamics of industrial change in the Bangkok urban region, to highlight problems, and to indicate how the region could both enlarge as well as fully harness its industrial potential. The focus of our analysis was on the formation of manufacturing and services clusters as well as the interaction among them. Our maintained hypothesis was that networked clusters of firms would promote gains in productivity, innovation, deepening of value added, and greater competitiveness overall. The presence of multiple clusters within a region is a source of resilience and can result in the emergence of new industries from a serendipitous combining of different skills and technologies. In addition, backward and forward linkages from manufacturing clusters (often located in peri-urban areas) can galvanize services in the core city and create virtuous spirals of employment and growth. For example in the U.S., manufacturing industries are the most export oriented, however the direct and indirect employment in services activities embodied in the exports of goods accounted for 39 percent of the total employment generated by manufactured exports (Istrate, Rothwell and Katz 2010; and Ferrantino, Trachtenberg and Weingarden 2010).

Have integrated clusters of firms materialized in the Bangkok urban region and are clusters of manufacturing firms linking to clusters of services providers in the Bangkok? If not, what policies could hasten such a development? These were the two questions motivating our research which drew upon the available literature on the region, GIS based district level data on firms and surveys of firms. 
Very briefly, our investigation uncovered evidence of robust investment activity and new firm formation in all of the key industrial subsectors - electronics, textiles, food processing, auto parts and assembly, and metal working - and also the major services providers - finance, publishing, research, IT, etc. We also found evidence of a shift in manufacturing activity towards the east and southeastern part of the region although many manufacturing firms remained in Bangkok and Bangkok metropolitan region and the majority of services providers concentrated in the city, as would be expected.

There are large groupings of firms throughout the region, many of which have collected in and around industrial parks, and the industrial firms utilize services offered by firms in the city. But because most firms are engaged in processing or assembly operations of standardized products using codified technologies, the integration of firms into clusters characterized by I-O relationships, coordination of activities and competition, has yet to crystallize. The Bangkok urban region has acquired the advantages of agglomeration, scale, and infrastructure but industrial clustering that would spur upgrading, innovation and significant gains in productivity, remains to be realized.

The study finds that industrial change and the formation of productivity enhancing clusters in the Bangkok urban region is being hampered by a number of constraints:

- The technical, language and soft skills of the factory labor force.

- The quality and volume of science and engineering skills.

- The physical infrastructure in and around the industrial estates. Clearly also there is room for adding to the capacity of the transport infrastructure connecting production nodes in the urban region ${ }^{3}$ to the port of Laem Chabang as well as the capacity of the intra-city network in Bangkok.

- The ICT infrastructure lags behind that of Korea, Taiwan (China) and Singapore and this could be constraining firm productivity.

- Living conditions, services and amenities in the satellite cities do not induce some white collar and skilled workers to shift from Bangkok and this inhibits the seeding of clusters in promising locations close to but outside of Bangkok.

- Research, problem solving and technology development capacity at universities needs strengthening so as to stimulate links with the business sector.

The above leads us to a number of recommendations that could contribute to the competitiveness and growth prospects of industry in the Bangkok urban region.

\footnotetext{
${ }^{3}$ Improving the roads so that they could accommodate heavier vehicles would reduce transport costs and traffic accidents.
} 
- The region should aim to build capabilities in a number of areas -In the manufacturing sector, autos, textiles and food processing ${ }^{4}$ are the most promising. In services, logistics, marketing, design and publishing could become important sources of growth and co-create value with manufacturing activities. Their prospects would be enhanced through localized clustering that boosts productivity and innovativeness.

- The future of each of these industries will depend upon technological excellence and innovation. The auto industry will have to find a niche in light trucks, motorbikes, and small cars that are increasingly fuel efficient, and the local electronics industry might be oriented to serve the needs of the auto sector. Textiles and garments need to increase competiveness through greater emphasis on new materials serving other sectors, such as automotive, construction and medical services and through better design. The food industry needs to mobilize the techniques of bioengineering and other disciplines to upgrade the entire supply chain and focus on innovations in products, packaging and marketing.

- Thailand's business climate could be improved. The weaknesses - and recent deterioration - have been documented by the World Bank's Thailand Investment Climate Assessment report and other reports on competitiveness.

- Localized clustering and innovation that would promote sustainable growth are within reach. Whether this occurs will depend upon four factors, assuming of course that the business climate encourages investment.

(1)A well articulated and strongly championed government strategy for the development of the Bangkok urban region that emphasizes the role and functions of clusters and wins the active support of other major stakeholders.

(2)Major local firms - and a pool of smaller firms augmented by start-ups with innovative products or services ${ }^{5}$ - must set the pace and with policy encouragement, make technological advances central to their competitiveness. This calls for a major shift in the strategy and objectives of managements and improved managerial skills. Ultimately it is the

\footnotetext{
${ }^{4}$ This portfolio of industries would combine the advantages of innovativeness and stable growth. They would also draw upon the accumulated comparative advantage of the region.

5 The importance of new high impact firms in boosting growth is noted by Sallet, Paisley and Masterman (2009).
} 
management of Thai firms that will determine whether the Bangkok urban region becomes a home to innovative clusters of firms.

(3)Existing and new firms will need all the help they can get from two sources. ${ }^{6}$ First, two or three universities in the Bangkok urban region must achieve levels of excellence in teaching and S\&E research comparable to the best in Asia if not the world. In particular, they must focus on engineering and bioscience departments that can cater to the needs of the leading industries and become a source of entrepreneurship as well (Audretsch 2008). Efforts by universities, when matched by a change in attitudes of management, can together accelerate the tempo of technological change and push Bangkok's industrialization to the next level. ${ }^{7}$ Second, managers and entrepreneurs will need assistance from providers of finance, of research, of design and other services. These are adequate but they must become world class.

(4)Lastly, Bangkok must ensure that public amenities, services, housing and transport infrastructures receive sustained attention and financing. The quality of life will be vital to retaining a large talent pool, attracting investment and sustaining the tourist industry.

It is not just the livability of Bangkok that is critical, but also the livability and urban attractiveness of the smaller cities in the Bangkok urban region that are likely to be the nodes for new local industrial clusters. If these cities are to play the roles expected of them, then they too must provide services, amenities and infrastructure sufficient to draw and retain a class of knowledge workers who currently are unwilling to forsake Bangkok. This transformation of secondary cities will require local leadership ${ }^{8}$ and better planning, governance, financing and effective inter-jurisdictional coordination.

It is through such a combination of initiatives that Bangkok will become an urban mega region that can sustain rapid growth and compete with other dynamic regions in Asia.

\footnotetext{
${ }^{6}$ See Gertler and Wolfe (2004) on the contribution of catalytic firms, universities and research centers. Smaller firms which cannot afford to maintain their own research staff are more likely to seek the assistance of a university if one with the expertise is nearby (Power and Lundmark 2004).

${ }^{7}$ Liefner and Schiller (2008) point to the limited capabilities and contribution of Thai universities to date and stress the advantages of greater investment in universities and restructuring of their internal organization. Sohn and Kenney (2007) draw attention to the contribution of Korean universities to technological advancement through high quality training.

${ }^{8}$ Sallet, Paisley and Masterman (2009) highlight the role of local leadership in cluster formation. Webster (2004) notes that many of the industrial estates are located not in municipalities but in Tambon Administrative Organizations which are rural oriented and are the least sophisticated forms of government in Thailand.
} 


\section{The Rise and Dominance of the Urban Region}

Globalization by introducing many new positive possibilities for and threats to urban production systems appears to be favoring the large urban regions comprised of several linked cities. ${ }^{9}$ The most dynamic among these regions enjoy the scale economies bestowed by vast markets, urbanization economies arising from industrial diversity and deep labor markets, and also localization economies arising from industrial specialization in individual cities or industrial clusters. ${ }^{10}$ Several such regions have emerged during the past century and others are coalescing in the industrializing countries of Asia and Latin America with coastal areas proving to be more attractive than inland areas for reasons of climate, water availability and ease of transportation. In the United States, for example, over one half of the population lives within 50 miles of the coast, ${ }^{11}$ and about 16 percent of all Americans, reside in one of six major urban regions. China's three main urban regions in the Pearl River Delta, the Changjiang Basin and the Bohai area account for one quarter of the population, two thirds of industrial production and 80 percent of exports. ${ }^{12}$ The belt of manufacturing stretching southwestwards from Sao Paolo is the industrial heartland of Brazil and industrial regions are emerging in India around Delhi, in the Mumbai-Pune-Nasik area, in East Punjab and in the states of Tamil Nadu and Karnataka. There are thriving large and medium sized cities in Brazil, China, India and the U.S. that do not belong to an urban region. However, it does appear that the pace of economic activity in these major economies and in others such as Germany and the U.K. is being set by industrial change, innovation and ideas generated in a few big metro regions. And there is little evidence to suggest that a reversal of this trend is in the offing: the economic dominance of urban regions is seemingly here to stay and the pressures arising from climate change and resource scarcities could promote the consolidation and densification of economic activity in existing regions rather than the multiplication of urban regions, although in highly populous industrializing countries such as China and

\footnotetext{
${ }^{9}$ See Scott (2008: p. 36). The UN Habitat report for 2010 observes that mega cities are spawning mega regions stretching over hundreds of kilometers with populations of tens of millions of people. The largest such region comprised of the cities of Hong Kong, Shenzhen and Guangzhou contains some 120 million people.(UN-HABITAT 2010). Later in this monograph we will have more to say about connected urban development which seeks to link cities together with the help of ICT.

${ }^{10}$ Allen Scott (2008: p. 32) refers to the mutual traded and untraded interdependencies that comprise the dynamic urban space giving rise to "multiple externalities, increasing returns, agglomeration economies and other social benefits (and costs) that are produced and consumed by all individual participants."

${ }^{11}$ Rappaport and Sachs (2003).

${ }^{12}$ One scenario envisages the concentration of China's urban population in 15 super cities with 25 million or more people. A similar concentration of 60 percent of India's population in 12 super cities would result in urban regions with up to 70-80 million people. In commenting on these proposals, Henderson (2010, p 531) notes that as yet we know relatively little of the efficacy of such large urban areas and it is difficult to extrapolate from the experience of Tokyo.
} 
India, a few new regions are bound to arise in strategically located inland areas with an adequate supply of water. ${ }^{13}$

The characteristics of urban regions differ depending on a country's stage of development and the stage in the life cycle of the region itself. In middle income countries, for example, manufacturing industries are invariably the drivers of growth, although services employ a higher percentage of the workforce and have tended to displace manufacturing from the core city areas (Henderson 2010). ${ }^{14}$ In the lower middle income countries, resource based processing and assembly type industries account for the largest slice of manufacturing and they produce standardized products using mature technologies. Some of the manufacturing industries might be classified as technology intensive but even these are low value adding activities relying on codified procedures to assemble products using mainly imported intermediate components and raw materials. Manufacturers tend to be far more export oriented and concentrated in a small number of urban centers. ${ }^{15}$

The composition of economic activities differs in the more mature urban regions in middle or upper middle income countries. Here the manufacturing industries are operating closer to the technological frontier and creating and producing more sophisticated and complex products. Business services bulk larger and there is likely to be significantly greater interaction between services providers and manufacturers because high tech and creative industries fostering new starts draw more extensively on the services of venture capitalists, IP lawyers, management consultants, headhunters and others. It should be noted though that individual cities within an urban region may be more or less specialized and might have distinct functional objectives that affect the composition of activities. For example, a financial center will differ significantly from one that has a concentration of high-tech manufacturing.

A relatively mature industrial-urban region may nurture more intra-industrial networking and also closer business relationships with services providers because of the nature of what is produced, because the technology is still evolving, and because the production system benefits from the adjacency of suppliers that work closely with final producers to design and develop products and ensure just-in-time delivery of parts or of services. Such input-output relationships in conjunction with other factors provide the underpinnings of cluster formation in urban regions.

\section{The Making of a Dynamic Urban Region}

\footnotetext{
${ }^{13}$ See the papers on urban regions in Scott (2001).

${ }^{14}$ UNIDO (2009).

${ }^{15}$ This is also the case in the United States (Istrate, Rothwell and Katz 2010).
} 
The competitive advantage of urban regions with multiple satellite or edge cities in the near vicinity of one or two major core cities derives from success at maximizing the gains in productivity from agglomeration, scale, and urbanization economies. ${ }^{16}$ Urban regions in the middle income countries are all in a "catch-up" phase of industrialization with plenty of scope for enhancing productivity by narrowing intra-industry differentials among firms (Syverson 2010, Bloom and Van Reenen 2010), through cluster formations that exploit synergies and internalize externalities, through a process of "open agglomeration" that more closely networks firms in the urban region with other suppliers, buyers, sources of skills and markets for technology within the country and abroad. ${ }^{17}$ The dynamic regions are quick to harvest the low hanging fruit, actively searching for the more profitable opportunities, and mapping strategies for what they want to become ten years later. No two pathways are alike, however, dynamic regions share certain attributes. Self organizing market processes can do wonders but successful urban regions are more effective at framing a strategic vision, at creating mechanisms to facilitate a coordinated approach to realizing desirable objectives and settling interjurisdictional disputes, and building the region-wide administrative capabilities to implement projects quickly and with relatively little waste. Much of this activity lies in the domain of the public sector.

The dynamic and productive region is conspicuous in five other respects:

- It contains a mix of industrial activities and by virtue of accumulated production capabilities demonstrates considerable flexibility in exiting or relocating activities subject to declining profitability, and embracing activities with more promising longer term prospects. Industrial capital and diversity is a key to flexibility, however, local entrepreneurship, sources of patient capital, space for new industries to take root, institutions facilitating exit of faltering industries, ${ }^{18}$ and incentives for attracting foreign capital and expertise are other factors that contribute to flexibility.

- The physical and economic integration of the urban region is vital. Achieving this requires at the minimum an efficient multimodal transport system and a state of the art ICT infrastructure. It entails in addition, institutional mechanism for inter-jurisdictional coordination of fiscal systems and a

\footnotetext{
${ }^{16}$ Henderson (2010, p. 524) observes that with development, "the largest cities become inefficient [and expensive] locations for standardized manufacturing...[hence] manufacturing decentralizes to periurban and suburban locations where rents and wages are cheaper but firms still have access to the infrastructure of the largest cities and often government offices to deal with red tape."

${ }^{17}$ Gertler and Wolfe (2004: p. 1078) observe that "a greater proportion of the production of complex technologies ranging from IT to automotive assembly occurs in these modular production networks with activities dispersed across a wide range of global locations."

${ }^{18}$ Exit is often linked with local labor laws that determine the cost and ease of lay-offs.
} 
meshing of rules and statutes among the municipal entities in the region. Connectivity with other cities and the global economy is a function also of the transport and telecoms infrastructure.

- Urban regions that plan strategically commit to steady incremental improvements in the quality of life for the vast majority through environmental gains, affordable housing, better amenities, improved services, less inequality and little crime (see Glaeser and Gottlieb 2009).

- The dynamic and flexible region gives due attention to the volume and quality of human capital of all sorts: technical, scientific, vocational and managerial. Two factors are decisive in this regard: one is the excellence of schools and tertiary level institutions of all sorts and how effectively they interact with and cater to the needs of local employers. The second is the region's ability to retain homegrown talent and bring in talent from elsewhere because of the quality of life and job opportunities associated with industrial growth, diversification and profitability of local firms.

- No urban region is an island unto itself. The ultimate test is economic competitiveness which is a function of national policies promoting openness to trade, to ideas, to capital and to visitors. The national government also defines the legal parameters for city authorities and these legal frameworks delineate the scope for initiatives by a city. Furthermore, center-local fiscal arrangements determine the resource envelopes for cities affecting how much revenue they can raise, how much they can keep and how much they can expect to receive from higher level authorities (see Frug and Barron 2008).

Southeast Asia is home to a number of large urban regions. Cross country experience, recent developments, migrant flows, and anticipated global changes all point to the increasing prominence of these regions in their respective countries and their importance as drivers of growth. It is therefore, becoming vital to assess how effectively key urban regions are tackling the challenges they face: of sustaining industrial dynamism and competitiveness, of maximizing the growth of productivity and of laying the foundations of flexible and innovative economies that will be resilient in the face of shocks.

The purpose of this study is: to examine the evolving composition and spatial distribution of manufacturing industries and business services in the Bangkok urban region; to assess the nature of the agglomeration process and any emergent clustering of firms; to determine whether the ground work is being laid for an upgrading of industrial activity; 
and to explore how Thailand could capitalize more fully on the industrial capabilities inherent in the Bangkok urban region.

This region is a construct of our creation and it is comprised of Bangkok, the Bangkok metropolitan region (comprised of Bangkok and the provinces of Nonthaburi, Samut Prakan, Pathum Thani Samut Sakhon and Nakhon Pathom), plus the provinces of Chachoengsao, Chonburi, Rayong and Phra Nakhon Si Ayutthaya. The provinces added to those already in the metro area are ones that have absorbed the new industrialization oriented towards and integrated with the economy of the core metro region. All references in the text to Bangkok are to the city alone, those to the vicinity refer to eight provinces (all the ones listed above except Nakhon Pathom) and the Bangkok urban region represents Bangkok and eight provinces.

A point we want to underline at the outset is that a viable recipe does not specify fixed ingredients or a given sequence, but arriving at desired outcomes requires choosing among ingredients and skillful cooking. Experience teaches us that ingredients are not immutable - there are substitutes; certain steps can be skipped, but broadly speaking urban regions must cook with variants of the ingredients listed above. We also need to underscore that an urban region is a part - an important one - of a national economy and its fortunes are affected by national policies and by other factors influencing the performance of the national economy. 


\section{The Bangkok Urban Region in the National Economic Context}

The Bangkok urban region is Thailand's economic engine. If it speeds up, the economy grows faster; if it falters, Thailand is in trouble. Currently over a third of GDP is generated in the metro region alone (i.e. Bangkok and its five adjacent provinces). The total area is 7,761.5 sq km and the population is almost 12 million. The urban region is of course much larger and it accounts for an even greater share of the GDP, possibly closer to 50 percent. A large part of Thailand's industry is located in the Bangkok urban region and the bulk of business services as well. Industrialization took root in the core metro area starting in the 1960s and although with encouragement from the government, some industry has migrated to the Eastern Seaboard area, it has not gone far. Efforts to disperse industry to other parts of the country distant from Bangkok and create additional industrial nodes, have failed to significantly dent the concentration of economic activity in Thailand's primate urban region. This is in part because Bangkok has accumulated overwhelming first-mover agglomeration economies which exert a profound gravitational pull. In part, it is because industrial development and investment in manufacturing have slackened significantly since the mid 1990s and absent a nascent manufacturing base, cities competing against Bangkok face difficulty in acquiring industrial traction. Partly also the layout of the transport infrastructure, the logistical advantages of a coastal location, and the preferences of foreign investors that have strongly influenced Thai industrial development, explain the continuing primacy of the Bangkok region.

As Deichmann and others (2008) note, Jakarta has experienced a similar outmigration of manufacturing firms to the peripheral parts of the Greater Jakarta metropolitan region. They observe that "these moves were facilitated by the construction of toll ring roads around the city which allowed firms to retain most of the agglomeration benefits of the region while avoiding the rising production costs associated with congestion and higher land rents. Aggregate transport costs per unit of sales revenue dropped, because a larger market could be accessed by a better road network" (p. 242). This development in the Greater Jakarta or Jabotek region is very similar to the spatial dispersion of industry in the Bangkok urban region.

Bangkok and its neighboring provinces are likely to dominate the urban-industrial landscape for the foreseeable future. For at least the next decade and most likely beyond, Bangkok's economic performance and that of Thailand as a whole, will be tied to the tempo of the existing industrial activities primarily manufacturing but also some producer services, through exports and increased domestic sales, supplemented over time by the diversification and technological upgrading of industry. 


\section{Varieties of Industrial Aggregation}

The economics of agglomeration ${ }^{19}$ is a burgeoning field because of the inexorable upward urbanizing trend worldwide and also because an increasing share of future economic growth will derive from gains in the productivity and innovativeness of urban activities. In this context, industrial and services clusters have attracted much research and policy attention because they can become vehicles for initiating growth spirals by inducing startups, and building flexibility into an economic region (see Yusuf, Nabeshima and Yamashita 2008). ${ }^{20}$ Clusters within which firms collaborate and compete, exchange information and induce a deepening of the market for skills can yield a number of growth promoting benefits. They give rise to technological spillovers and other externalities; they can stimulate incremental technological change; they can quicken investment and the rate of change of productivity; and they create demand for supporting activities, especially services. A thriving cluster can be a powerful force that pulls in FDI and domestic investment, deepens the pool of skills, accelerates technological advances and burnishes the image of a city - that is, it gives rise to reputational externalities. Hsinchu Park outside Taipei, the heartland of the semiconductor industry in Taiwan (China) is one such cluster (Mathews and Cho 2000); Bangalore which is India's preeminent software hub is another example of a successful cluster; the Zhongguancun technology zone in Beijing which spawned China's modern computer and software industry, is a third (Zhou 2008); the Medicon Valley biotech cluster in Denmark and Southern Sweden is a fourth (Steinfield, Scupola and Lopez-Nicolas 2010). ${ }^{21}$ Each of these have been game changers for their respective economies and helped to catapult them to the front ranks of industrializing countries.

\footnotetext{
${ }^{19}$ Proximity reduces the costs of moving goods, interaction between people and the circulation of ideas. See Glaeser and Gottlieb (2009); Glaeser (2010); Ellison, Glaeser and Kerr (2010); and Puga (2010) for recent surveys.

${ }^{20}$ The seminal paper is by Porter (1998). See also Sallet, Paisley and Masterman (2009); Cooke (2004); Humphrey and Schmitz (2002); Andersen (2006); Kenney and Patton (2006); Rodriguez-Clare (2007); Drofiak and Garnsey (2009); and OECD (2001).

${ }^{21}$ The Hsinchu cluster was born in 1973 when the Taiwanese government created the Industrial Technology Research Institute (ITRI) in response to a series of economic and political crises. ITRI was designed to serve as a collective laboratory for IT firms in Hsinchu. It merged three existing nongovernment R\&D institutions and also created the Electronics Research and Service Organization (ESRO). In 1976, ITRI initiated Taiwan's first-ever technology transfer from RCA and the U.S. accelerated the process of technology transfer and assimilation. The founding of United Microelectronics Corporation (UMC) in 1980 contributed further to the development of Hsinchu Park by inserting an axial player into the cluster to fill local market needs. Zhongguancun owes its origin to the Chinese entrepreneur Chunxian Chen, who started a business initiative in Zhonguancun in 1980 after visiting Silicon Valley. By 1984, he founded Lenovo and inspired many scientists and engineers belonging to research institutes in the area. In 1988 the government responded to the growing number of start-ups and began to create economic policies to aid the development of Zhongguancun. "Of the policies aimed to foster entrepreneurial venturing in Zhongguancun, the most influential was the National Torch Project carried out by the State Science and Technology commission in 1988. Its purpose was to construct the science and technology industry parks to incubate new start-ups in Zhongguancun in particular and China in general." (Tzeng 2010: p 116)
} 
When clusters take root and flourish they can contribute significantly to the pace and the sustainability of growth by enhancing competitiveness, by stimulating other complementary activities which can become economic drivers themselves, and in the most successful cases, by growing the innovation capabilities that can lead to the emergence of new industrial activities higher on the ladder of technology. Over the past two decades the characteristics of clusters have become more varied. At least four factors are at work: product standardization and the modularization and codification of technology in key industries; the emergence of production networks that connect producers dispersed over a wide area; the adoption of ICT and supply chain technologies supporting coordination among dispersed production units; and 'open technology' development and sharing arrangements facilitating interaction and knowledge spillovers almost irrespective of distance. As a consequence, for some industries clustering does not necessarily require the physical proximity of numerous firms engaged in supplierbuyer relationships or competitive-collaborative relationships. ${ }^{22}$ All this can happen among widely separated firms so that clustering can become a 'virtual process' and much more spatially expansive thanks to the integrative powers of ICT, of modern logistics and the effective fine-tuning of international production networking over the course of almost three decades through the midwifery of MNCs and specialized integrators. ${ }^{23}$ The mechanics of clustering have become more varied and the industrial evolution of clusters that are in part 'virtual', has become more complex.

The Bangkok urban region hosts a number of industries. Auto parts and auto assembly, electronics, food processing, textiles, metal working and jewelry industries are present in and around the metro area. Business services have concentrated in the core areas of the municipality. Strategic investments in transport infrastructure have reinforced Bangkok's locational advantages and made Bangkok one of the principal logistics hubs in the Southeast Asian region. Together this combination of industry and services has contributed to the growth of Bangkok and of Thailand as a whole over more than three decades.

The question at the heart of this study can be phrased as follows: Given that concentrations of key manufacturing industries and services are vital to Bangkok's economic health, are these coalescing spatially into conventional industrial clusters with the requisite networks, inter-firm collaboration, and associated labor markets; are these concentrations densifying through the entry of new firms; and are manufacturing clusters crowding in services providers in their immediate vicinity or are they multiplying their links with firms offering services that are grouped in the core areas of the city and

\footnotetext{
${ }^{22}$ See for example Leibovitz (2004) who comments on the dispersion of biotech firms in Scotland and the weakness of linkages among them.

${ }^{23}$ Fung, Fung and Wind (2008).
} 
elsewhere? Moreover, is the entire urban region integrating through cross hatching links among aggregations of firms which can help to magnify agglomeration economies, increase industrial flexibility and facilitate diversification? In other words, are the localization economies from industrial specialization in smaller cities spread across the urban region being compounded by urbanization economies of an industrially diverse, well articulated, polycentric urban region? Or has agglomeration and clustering in the Bangkok region been on virtual lines? If so, what is the next stage of development for the region? How might it raise the level of its game and remain the driver of Thailand's growth? Before coming to grips with these questions, we need some essential background on Thailand's economic circumstances.

\section{Recent Performance of the Thai Economy}

Thailand is at a development crossroads and Bangkok's economy will determine the way forward. To understand why this is the case, it is necessary to review a number of indicators that capture recent trends. Thailand's growth rate, which was slowing in 1996 and plunged sharply during 1997-1998, has remained below the levels reached in 199095. Growth turned negative in 2008-9 (-2.2 percent) and although it has rebounded to nearly 6 percent in 2010 assisted in part by restocking and the revival of exports, prospects over the medium term look less promising than was the case during 2002-2007 (see

Figure 0.1). Domestic investment followed growth downward after the mid 1990s, it stagnated through 2008 at about 22 percent and fell by 9 percent in 2009 (see Table 0.1). ${ }^{24}$ Recovery in 2010 is not expected to restore the absolute level reached in 2008 . A decline in foreign direct investment from $\$ 11.3$ billion in 2007 to $\$ 5.9$ billion in 2009 (UNCTAD 2010) has affected all sectors, however, the scaling back of flows has been more marked in services and real estate than in manufacturing. As a consequence, the share of services in value added which approximated 49.5 percent during 1990-2000, had slipped to 45 percent in 2007 (See

\footnotetext{
${ }^{24}$ This is consistent with research on other countries which shows that after a severe shock, GDP levels can be permanently depressed and growth rates can take time to recover, if they recover fully at all.
} 
Figure 0.2). Growth during 2000-2008 was sourced mainly from exports and domestic consumption (see Table 0.3 and

Table 0.2). The sources of growth from the supply side during 1977-2004 were capital which contributed 3.1 percent and total factor productivity which was responsible for 1 percent (See

Table 0.4). Labor accounted for the remainder. With the growth of global trade likely to be slower over the medium term as the U.S. and the EU economies running deficits attempt to rebalance their external accounts, Thai exporters will need to compete harder to maintain or enlarge their shares in OECD and Asian markets in the face of competition from firms in China and other Southeast Asian countries. And with capital investment shrinking, Thailand will be more dependent on the growth impetus from productivity gains and innovation. Thus industrial upgrading and diversification into higher technology activities and more efficient use of resources by the leading manufacturing activities take on a greater significance, as do the productivity gains from urbanization and localization economies in the Bangkok urban region.

Figure 0.1: Thailand Real GDP Growth (Annual \%)

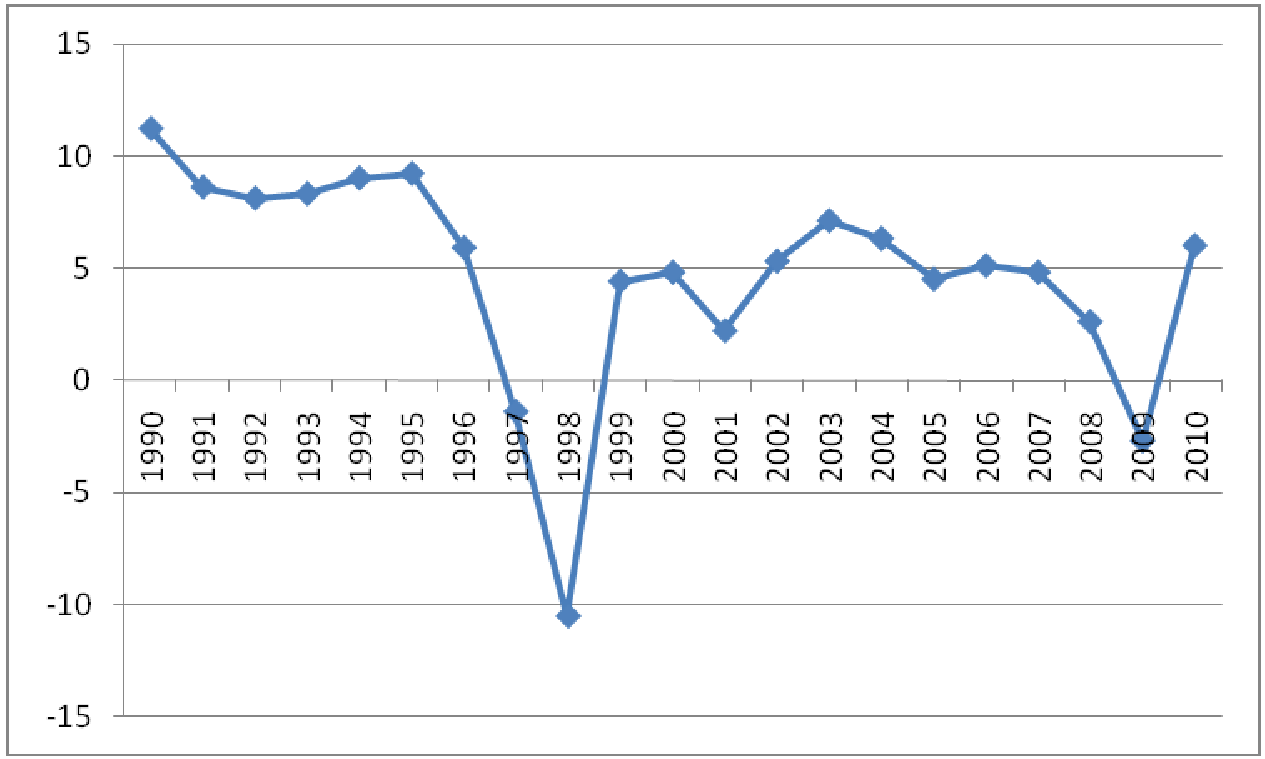

Source: World Development Indicators Note: 2010 is World Bank projection

Table 0.1: Thailand, Shares in GDP (\%)

\begin{tabular}{ccccc}
\hline Average & Average & & \\
$1995-$ & $2001-$ & & \\
2000 & 2007 & 2008 & 2009 \\
\hline
\end{tabular}




\begin{tabular}{lllrr} 
Gross Fixed Capital Formation & 30.2 & 26.7 & 22.1 & 20.6 \\
Exports of goods and services & 52.2 & 71.7 & 72.5 & 64.2 \\
Imports of goods and services & 47.9 & 66.95 & 57 & 47.0 \\
\hline
\end{tabular}

Source: World Development Indicators; NESDB and WB staff calculations; WB projections for 2009 
Figure 0.2: Thailand Composition of GDP (Supply Side)

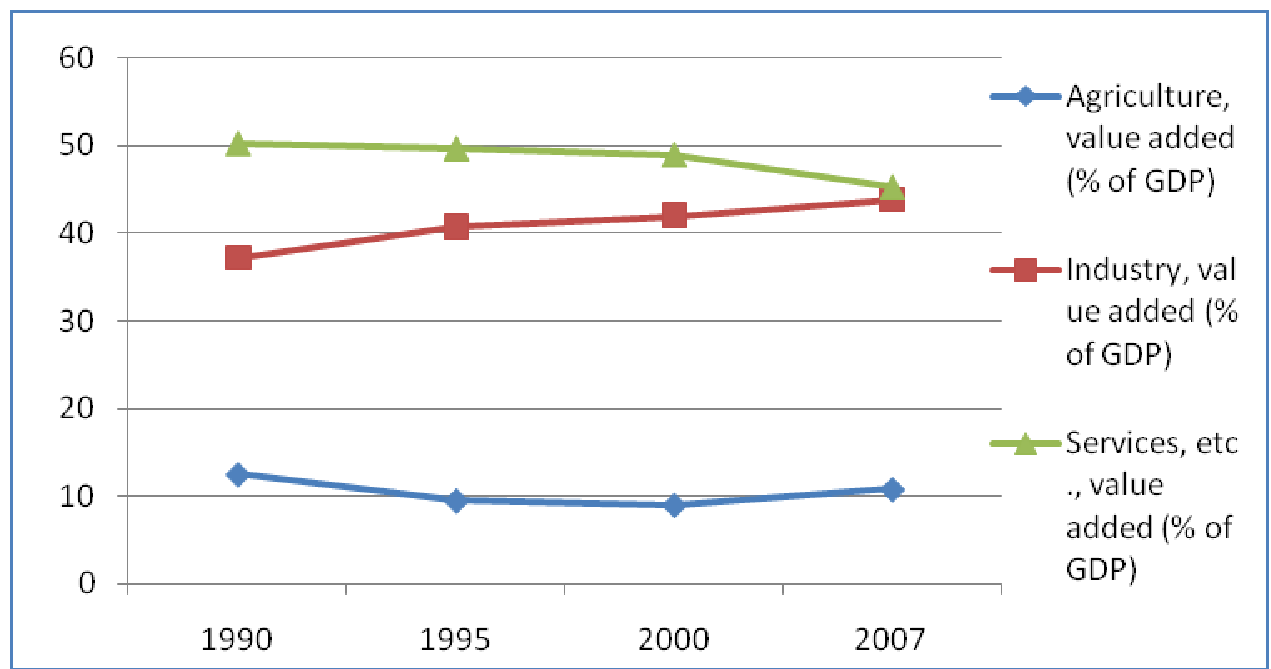

Source: World Development Indicators

Table 0.2: Contribution to GDP Growth by Sector (Demand Side), percentage points

\begin{tabular}{lrrrr}
\hline & $\mathbf{1 9 9 0}$ & $\mathbf{1 9 9 5}$ & $\mathbf{2 0 0 0}$ & $\mathbf{2 0 0 7}$ \\
\hline Household final consumption expenditure & 7.2 & 4.3 & 2.8 & 0.8 \\
General government final consumption expenditure & 0.6 & 0.4 & 0.2 & 0.9 \\
Gross fixed capital formation & 9.9 & 4.6 & 1.1 & 0.3 \\
Changes in inventories & 0.7 & 1.3 & 1.1 & -0.2 \\
Exports of goods and services & 4.8 & 6.9 & 10.1 & 4.8 \\
Imports of goods and services & -8.8 & -9.5 & -11.1 & -1.9 \\
Discrepancy in expenditure estimate of GDP & -3.3 & 1.2 & 0.5 & 0.3 \\
GDP growth & 11.2 & 9.2 & 4.8 & 4.9 \\
\hline
\end{tabular}

Source: World Development Indicators

Table 0.3: Contribution to GDP Growth by Sector (Supply Side), percentage points

\begin{tabular}{lrrrr}
\hline & $\mathbf{1 9 9 0}$ & $\mathbf{1 9 9 5}$ & $\mathbf{2 0 0 0}$ & $\mathbf{2 0 0 7}$ \\
\hline Agriculture, value added & -0.6 & 0.4 & 0.6 & 0.5 \\
Industry, value added & 6.0 & 4.4 & 2.2 & 2.5 \\
Of which Manufacturing, value added & 4.3 & 3.6 & 2.0 & 2.1 \\
Services, etc., value added & 6.4 & 4.4 & 1.8 & 2.0 \\
GDP growth & 11.2 & 9.2 & 4.8 & 4.9 \\
\hline
\end{tabular}

Source: World Development Indicators 
Table 0.4: Sources of growth in Thailand

\begin{tabular}{cccc}
\hline & & Capital & TFP \\
\hline \multirow{2}{*}{ Thailand } & $1977-2004$ & $3.1 \%$ & $1.0 \%$ \\
& $1977-1996$ & $4.0 \%$ & $1.6 \%$ \\
& $1999-2004$ & $0.9 \%$ & $2.1 \%$ \\
\hline
\end{tabular}

Source: Bosworth (2005).

\section{Comparative Advantage and Diversification Possibilities}

A useful starting point for a study of industrial evolution and prospects is the calculation of Thailand's export mix and trends, its revealed comparative advantage as evidenced by its exports, and alongside this, the computation of Thailand's product space. This latter exercise can indicate how production activities are currently distributed across the spectrum of possibilities and the degree to which the existing distribution allows for diversification to 'neighboring' activities, some of which may be technologically more advanced.

The export composition of Thailand has shifted from exports based on primary and resource-based and low-tech products towards medium- and high-tech products from 1990 to 2006. In 1990, resource-based products comprised close to 50 percent of Thailand's exports and one half of these were primary products (see

Figure 0.3). Garments and textiles accounted for $20 \%$ of the exports in 1995. By 2006, the share of primary products had decreased to just $13 \%$ of exports and the share of garments and textiles had shrunk to $7 \% .^{25}$ In contrast, the share of electronics, engineering, and automotive products increased, although that of electrical and electronics declined in 2006 compared to 2000.

\footnotetext{
${ }^{25}$ In order to boost the competitiveness of textile industry, the Thai government established a loan fund in 1997 through the ThTI (Thai Textile Institute) to encourage the purchase of new equipment. The Thai Garment Manufacturers Association and Thai Garment Development Fund also expanded its short courses and trained around 6,000 textile operators between 1997 and 2005 (Doner 2009). But Thailand among the top 15 textile exporting nations, had the lowest ratio of shuttles.
} 
Figure 0.3: Export Composition of Thailand, 1990-2006

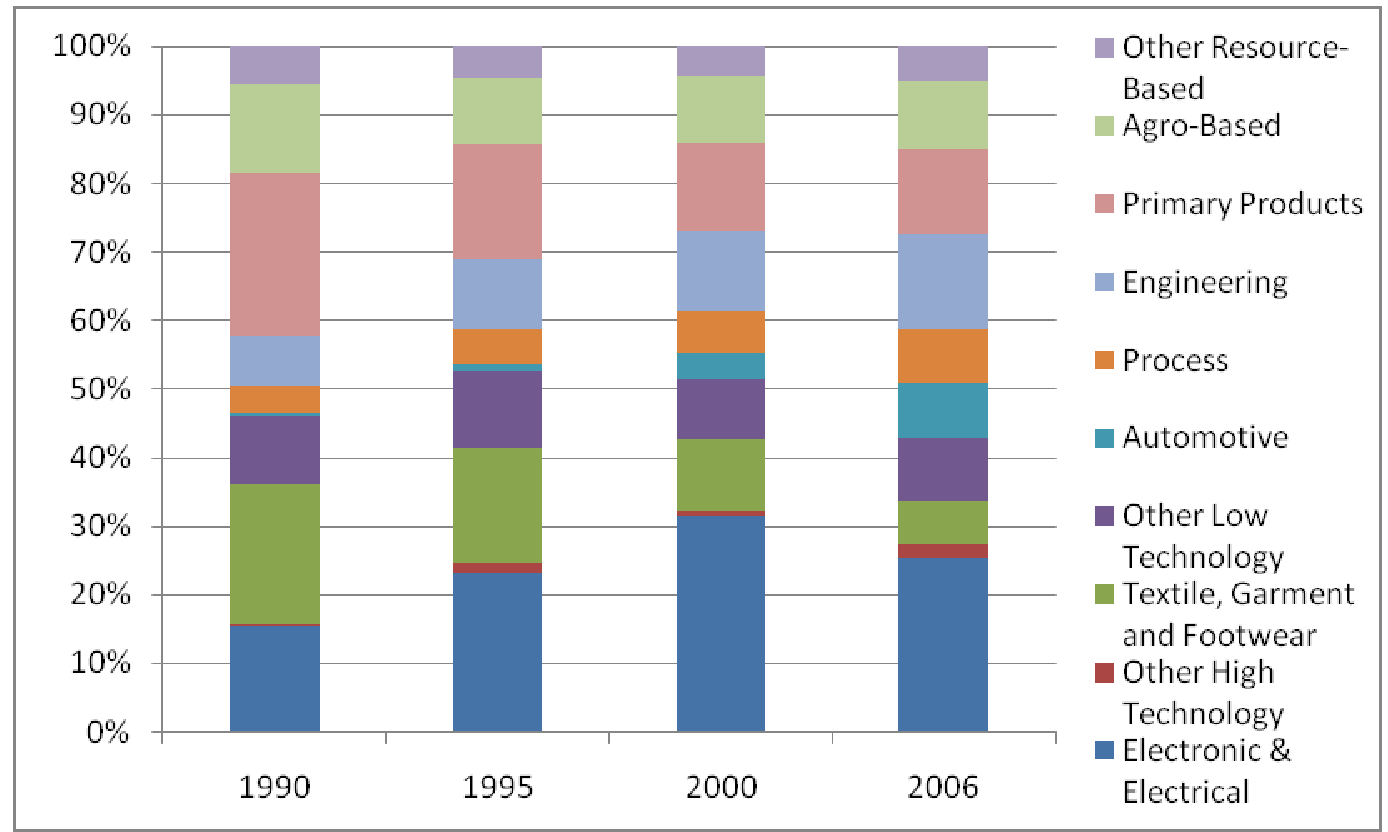

Source: UN COMTRADE

A tabulation of Thailand's ten largest exports in 1995 and 2006 also points to an increasing representation of high and medium tech electronic and automotive products (see Table 0.5 and Table 0.6). Latex products and rice remain important but others such as footwear, seafood and plastic products have been displaced by auto-parts and motor vehicles. This is a positive development and suggestive of deepening manufacturing capabilities in high tech product assembly and testing.

The product space for Thailand which points to the opportunities for diversification, is based on the current export basket (see Figure 0.4 and Figure 0.5). The underlying assumption of the product space analysis is that exporting a good requires certain capabilities, infrastructure and institutions, and such capabilities can be shared among different products. That is, if a country already exports a good, it has a higher probability of exporting similar goods. Product space analysis calculates the similarity between pairs of goods traded globally. ${ }^{26}$ Based on this similarity, density - which ranges from zero to one - can be calculated to measure the degree to which a country has accumulated the necessary capabilities. Higher density means, it is more likely that a country will export a particular good. A comparison of Table 0.7 with Table 0.8 points to a major shift in products with the highest density. This again suggests that on balance Thailand has

\footnotetext{
${ }^{26}$ For specific detail on product space analysis, see Hausmann and Klinger (2006) and Box 1 for elucidation of the concept and its extension by Felipe, Abdon and Kumar (2010).
} 
acquired technologies and is nurturing the necessary industrial capacity to diversify into higher value-added products principally auto parts and electronic products. 
The product space is derived from an application of network theory and attempts to represent all of the world's exports. The key concept is one of product proximity, that is a country is more likely to export items lying "close" to ones it exports where close is a measure of likelihood that product will be exported if a country exports a nearby product; in the product space some products are clustered together tightly in a dense region which comprises the core of the product space. These products include chemicals, machinery and metal products. The more rarefied parts of the product space includes many resource based products including petroleum and agricultural raw materials. It is relatively easy to branch out from the dense core into other products, much harder from products on the periphery. In other words, where a country is in the product space reflects acquired production capabilities and the scope for diversifying into more sophisticated products.

In assessing a country's capabilities and export dynamism, Hidalgo and Haussman rely on two indicators: EXPY which measures the sophistication of a country's exports. It is derived from PRODY which is the weighted average of the GDP per capita of countries exporting the product. EXPY is the weighted average of the income level of all the products exported, the latter being the weighted average of the PRODY.

Felipe, Kumar and Abdon (2010) have taken the product space based measures a step further by estimating a composite index of a country's production and export capabilities. The indicators combined are overall sophistication (EXPY); the sophistication of the products in the core; product diversification which is the number of products in which the country has a revealed comparative advantage (i.e. greater than 1); diversification of core products in which the country has a revealed comparative advantage; the level of capabilities arrived at by taking a ratio of commodities with an RCA greater than 1 to all commodities with a revealed comparative advantage; uniqueness measured by the number of countries exporting products similar to those of the country in question; and the "open forest" which is the expected value of the products a country could export but does not export with a revealed comparative advantage greater than one.

Felipe et al regress each of these indicators on a country's level of GDP per capita and by using the coefficient estimate and the residuals, construct an index of opportunities that a country faces. The index is scaled to lie between 0 and 1 with 1 representing the highest level of capability. Not surprisingly, China is at the top with an index of 0.90 followed by India and Poland with indices of 0.86 and 0.77 respectively. Lying in fourth place ahead of Mexico, Brazil, Malaysia and Indonesia is Thailand with an index of 0.76 . Thus according to this measure, Thailand has the industrial capability to transition to a significantly more sophisticated mix of products. 
Table 0.5: Thailand's Top 10 Exports, 1995

\begin{tabular}{lccr}
\hline Short description & $\begin{array}{c}\text { Trade Value } \\
\text { (in millions) }\end{array}$ & PRODY & $\begin{array}{r}\text { Technology } \\
\text { Class }\end{array}$ \\
\hline Peripheral units, including control and adapting units & 2,595 & 15,350 & HT1 \\
Natural rubber latex; natural rubber and gums & 2,459 & 2,081 & PP \\
Crustaceans and mollusks, fresh, chilled, frozen, salted, etc & 2,412 & 2,964 & PP \\
Parts, nes of and accessories for machines of headings & & & \\
7512 and 752 & 2,295 & 14,791 & HT1 \\
Footwear & 2,089 & 5,913 & LT1 \\
Electronic microcircuits & 1,939 & 12,645 & HT1 \\
Rice, semi-milled or wholly milled & 1,923 & 2,682 & PP \\
Miscellaneous articles of plastic & 1,153 & 10,934 & LT2 \\
Television receivers, color & 946 & 9,221 & HT1 \\
Parts, nes of and accessories for apparatus falling in & & & HT1 \\
heading 76 & 903 & 13,642 & \\
\hline
\end{tabular}

Note: PRODY is a measure of "sophistication" of a commodity, calculated as the weighted sum of per capita income of exporting countries.

Source: UN COMTRADE

Table 0.6: Thailand's Top 10 Exports, 2006

\begin{tabular}{lccr}
\hline Short description & $\begin{array}{c}\text { Trade Value (in } \\
\text { millions) }\end{array}$ & PRODY & $\begin{array}{r}\text { Technology } \\
\text { Class }\end{array}$ \\
\hline Peripheral units, including control and adapting units & 8,396 & 12,250 & HT1 \\
Electronic microcircuits & 6,309 & 16,464 & HT1 \\
Natural rubber latex; natural rubber and gums & 5,431 & 1,781 & PP \\
Parts, nes of and accessories for machines of headings & 3,730 & 17,453 & HT1 \\
7512 and 752 & 3,683 & 9,702 & MT1 \\
Motor vehicles for the transport of goods or materials & 2,922 & 14,917 & MT1 \\
Passenger motor vehicles (excluding buses) & 2,513 & 2,678 & PP \\
Rice, semi-milled or wholly milled & 2,500 & 13,505 & MT1 \\
Other parts and accessories, for vehicles of headings 722, & 2,314 & 10,719 & MT3 \\
781-783 & 1,984 & 9,868 & HT1 \\
Air conditioning machines and parts thereof, nes & & & \\
Television receivers, color & & &
\end{tabular}

Note: PRODY is a measure of "sophistication" of a commodity, calculated as the weighted sum of per capita income of exporting countries.

Source: UN COMTRADE 
Figure 0.4: Product Space of Thailand, 1987

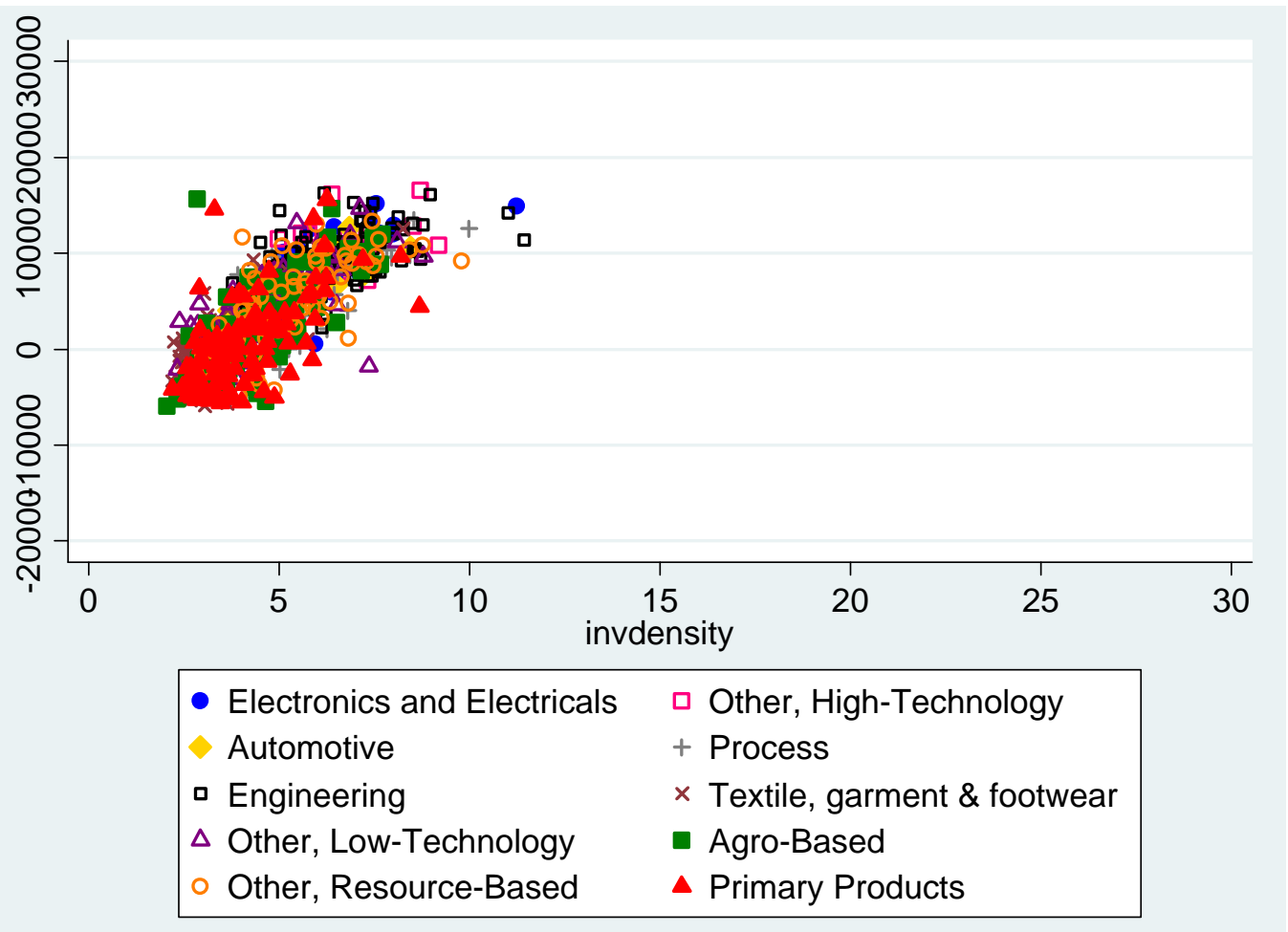

Note: The horizontal axis is the inverse of the density. The closer it is to the origin means the more likely it is that a country will export that commodity. The vertical line measures the difference between EXPY (average quality of a country's export basket) and PRODY (quality of each product). A product located above zero means that it is more sophisticated product than the average export goods.

Source: Authors' calculations based on UN Comtrade data

Figure 0.5: Product Space of Thailand, 2006 


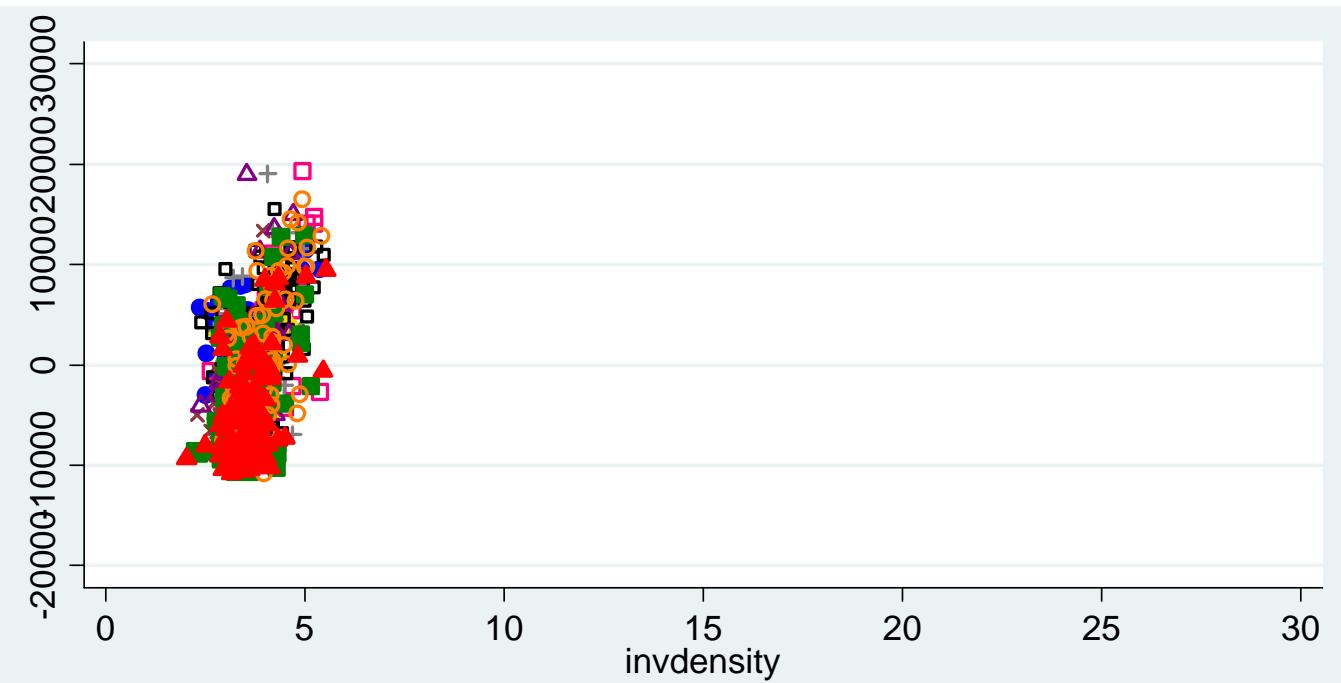

\begin{tabular}{|ll|}
\hline - Electronics and Electricals & $\square$ Other, High-Technology \\
Automotive & + Process \\
$\square$ Engineering & $\times$ Textile, garment \& footwear \\
$\Delta$ Other, Low-Technology & $\square$ Agro-Based \\
$\circ$ Other, Resource-Based & $\Delta$ Primary Products
\end{tabular}

Note: The horizontal axis is the inverse of the density. The closer it is to the origin means the more likely it is that a country will export that commodity. The vertical line measures the difference between EXPY (average quality of a country's export basket) and PRODY (quality of each product). A product located above zero means that it is more sophisticated product than the average export goods.

Source: Authors' calculations based on UN Comtrade data

Table 0.7: Top 10 "upscale" commodities with highest density in Thailand, 1995

\begin{tabular}{lccr}
\hline Short description & Density & $\begin{array}{c}\text { Technology } \\
\text { Class }\end{array}$ & PRODY-EXPY \\
\hline $\begin{array}{l}\text { Children's toys, indoor games, etc } \\
\begin{array}{l}\text { Crystals, and parts, nes of electronic components of } \\
\text { heading 776 }\end{array}\end{array}$ & 0.475303 & LT2 & 2,933 \\
$\begin{array}{l}\text { Photographic cameras, flashlight apparatus, parts, } \\
\text { accessories, nes }\end{array}$ & 0.456028 & HT1 & 2,437 \\
$\begin{array}{l}\text { Other sound recording and reproducer, nes; video } \\
\text { recorders }\end{array}$ & 0.440233 & HT2 & 4,705 \\
Clocks, clock movements and parts & 0.424881 & MT3 & 2,709 \\
Umbrellas, canes and similar articles and parts thereof & 0.396358 & MT3 & 4,109 \\
Electronic microcircuits & 0.382785 & HT1 & 1,805 \\
Portable radio receivers & 0.375738 & MT3 & 4,086 \\
Baby carriages and parts thereof, nes & 0.374736 & LT2 & 4,786 \\
Other radio receivers & 0.374579 & MT3 & 3,168 \\
\hline
\end{tabular}

Note: PRODY is a measure of "sophistication" of a commodity, calculated as the weighted sum of per capita income of exporting countries. EXPY is calculated as a weighted sum of PRODY, signifying the sophistication of export basket of a country.

Source: UN COMTRADE 
Table 0.8: Top 10 "upscale" commodities with highest density in Thailand, 2006

\begin{tabular}{lccc}
\hline Short description & Density & $\begin{array}{c}\text { Technology } \\
\text { Class }\end{array}$ & $\begin{array}{c}\text { PRODY- } \\
\text { EXPY }\end{array}$ \\
\hline Crystals, and parts, nes of electronic components of heading & & & \\
776 & 0.423955 & HT1 & 5,657 \\
Printed circuits, and parts thereof, nes & 0.417283 & MT3 & 4,218 \\
Peripheral units, including control and adapting units & 0.395574 & HT1 & 1,150 \\
Electronic microcircuits & 0.393997 & HT1 & 5,365 \\
Other sound recording and reproducer, nes; video recorders & 0.377896 & MT3 & 5,141 \\
Clocks, clock movements and parts & 0.376103 & MT3 & 3,162 \\
Pearls, not mounted, set or strung & 0.373857 & RB2 & 6,041 \\
Other electrical machinery and equipment, nes & 0.369362 & HT1 & 3,686 \\
Fabrics, woven, of continuous synthetic textile materials & 0.368156 & MT2 & 3,484 \\
Parts, nes of and accessories for machines of headings 7512 & & & \\
and 752 & 0.353374 & HT1 & 6,354 \\
\hline
\end{tabular}

Note: PRODY is a measure of "sophistication" of a commodity, calculated as the weighted sum of per capita income of exporting countries. EXPY is calculated as a weighted sum of PRODY, signifying the sophistication of export basket of a country.

Source: UN COMTRADE 
A somewhat different impression is conveyed by Table 0.9 which presents Thailand's most rapidly expanding exports between 2000 and 2007. According to this data, resource based and relatively low tech products are growing the fastest, items such as iron and steel manufactures, sugar, chemicals and tubes and pipes. The impression of an economy with a bifurcated production system - one part relatively high tech and the other resource based and relatively low tech - is reinforced by Table 0.10 on revealed comparative advantage (RCA) for 1995, 2000 and 2006. ${ }^{27}$ In the mid 1990s, Thailand's revealed comparative advantage lay in resource based and primary products - rubber, rice and vegetables being the three highest ranked. Five years later, there was little change. Rice had slipped to fourth place to be replaced by industrial diamonds, and seafood had edged out vegetables.

By 2006, the three highest ranked items were the same as in 1995 and all but one of the top ten products fell into the primary or resource based categories. What this all adds up to in terms of global shares can be seen in Figure 0.6. Thailand's share of garment exports peaked in the early 1990s and has been falling since. The share of electronics is almost flat since 1990 (with a slight upward tilt), but that of auto parts has risen strongly from about 1 percent of total world exports to 1.5 percent in 2007. The buoyancy of auto part exports has enabled Thailand to raise its share of total world exports to about 1.3 percent.

${ }^{27}$ The RCA is often used to measure the export competitiveness of a commodity (or an industry) of a country. It is a ratio of two shares: (a) the share of a commodity's export in the overall exports of a country and (b) the share of the same commodity in global exports:

$$
R C A=\frac{\text { Export }_{i j} \sum_{i} \text { Export }_{i j}}{\sum_{j} \text { Export }_{i j} / \sum_{i} \sum_{j} \text { Export }_{i j}},
$$

where $i$ denotes the commodity and $j$ denotes countries (over the set of commodities, $i=1 \ldots I$, and over the set of countries, $j=1 \ldots J$ ). An RCA greater than 1 means that the country has a revealed comparative advantage in that commodity, assuming that the numerator and the denominator are increasing. If that is not the case, greater care is needed in interpreting the results. Rearranging the equation, one can obtain

$$
R C A=\frac{\text { Export }_{i j} / \sum_{j} \text { Export }_{i j}}{\sum_{i} \text { Export }_{i j} / \sum_{i} \sum_{j} \text { Export }_{i j} .}
$$

The numerator is now country $j$ 's market share of commodity $i$ in the world export market, and the denominator is country $j$ 's share of exports in overall world exports. Thus, even if country $j$ is losing market share, if overall exports from country $j$ relative to world exports are shrinking faster, the RCA will be greater than 1 (Lall, Weiss and Zhang 2006). 
Table 0.9: Top 10 fastest growing exports from Thailand, 2000-2007

\begin{tabular}{llccr}
\hline Product & Product Name & $\begin{array}{c}\text { Trade Value } \\
\mathbf{2 0 0 7}(\mathbf{U S} \$ \\
\text { millions) }\end{array}$ & $\begin{array}{c}\text { Annual Growth } \\
\text { Rate (2000- } \\
\mathbf{2 0 0 7}\end{array}$ & $\begin{array}{r}\text { Technology } \\
\text { Class }\end{array}$ \\
\hline 720720 & Semi-fin prod, iron or non-alloy st & 19.57 & 416.3 & MT2 \\
282690 & Fluoroaluminates and other complex & 3.56 & 390.7 & RB2 \\
294000 & Sugars, pure (excl. glucose, etc); & 29.81 & 309.0 & RB2 \\
780110 & Lead refined unwrought & 1.65 & 305.3 & PP \\
290211 & Cyclohexane & 122.07 & 297.6 & RB2 \\
260200 & Manganese ores and concentrates, wi & 0.20 & 290.9 & RB2 \\
701332 & Table/kitchenware (exc drinking gls & 3.78 & 288.1 & LT2 \\
844512 & Textile combing machines & 0.23 & 283.5 & MT3 \\
730531 & Tubes \& pipe, i or s, longitudinall & 3.07 & 278.9 & MT2 \\
800300 & Tin bars, rods, profiles and wire & 17.00 & 272.7 & PP \\
\hline S015
\end{tabular}

Source: UN COMTRADE

Table 0.10: Top 10, 4-digit level Commodities with highest RCA in Thailand

(1995, 2000 and 2006)

\begin{tabular}{lccr}
\hline Short description & RCA & PRODY & $\begin{array}{r}\text { Technology } \\
\text { Class }\end{array}$ \\
\hline $\mathbf{1 9 9 5}$ & & & \\
Natural rubber latex; natural rubber and gums & 28.38 & 2,081 & PP \\
Rice, semi-milled or wholly milled & 27.03 & 2,682 & PP \\
Vegetable products roots and tubers, nes, fresh, dried & 26.88 & 3,212 & PP \\
Crustaceans and molluscs, prepared or prepared, nes & 21.34 & 20,872 & RB1 \\
Other articles of leather or of composition leather & 17.62 & 4,731 & LT1 \\
Articles of apparel, clothing accessories of plastic or rubber & 15.73 & 5,256 & LT1 \\
Vegetable textile fibres, nes, and waste & 15.01 & 3,764 & RB1 \\
Fruit, fruit-peel and parts of plants, preserved by sugar & 14.97 & 5,953 & RB1 \\
Gypsum, plasters, limestone flux and calcareous stone & 14.76 & 6,317 & PP \\
Precious and semi-precious stones, not mounted, set or strung & 13.67 & 4,601 & RB2 \\
2000 & & & \\
Natural rubber latex; natural rubber and gums & & & PP \\
Industrial diamonds & 35.92 & 1,669 & PP \\
Crustaceans and molluscs, prepared or prepared, nes & 32.78 & 1,452 & RB1 \\
Rice, semi-milled or wholly milled & 31.41 & 18,540 & PP \\
Vegetable products roots and tubers, nes, fresh, dried & 25.54 & 2,459 & PP \\
Gramophones and record players, electric & 20.55 & 1,744 & MT3 \\
Other articles of leather or of composition leather & 18.96 & 5,800 & LT1 \\
Fruit, fruit-peel and parts of plants, preserved by sugar & 14.07 & 5,922 & RB1 \\
Precious and semi-precious stones, not mounted, set or strung & 13.53 & 4,010 & RB2 \\
Starches, insulin and wheat gluten & 12.19 & 2,661 & RB2
\end{tabular}




\begin{tabular}{lccr}
\hline Short description & RCA & PRODY & $\begin{array}{r}\text { Technology } \\
\text { Class }\end{array}$ \\
& & & \\
$\mathbf{2 0 0 6}$ & & & \\
Natural rubber latex; natural rubber and gums & 32.45 & 1,781 & PP \\
Rice, semi-milled or wholly milled & 23.15 & 2,678 & PP \\
Vegetable products roots and tubers, nes, fresh, dried & 23.01 & 2,039 & PP \\
Hygienic, pharmaceutical articles of unhardened vulcanized rubber & 17.46 & 10,149 & RB1 \\
Starches, insulin and wheat gluten & 16.83 & 6,755 & RB2 \\
Crustaceans and mollusks, prepared or prepared, nes & 16.11 & 17,929 & RB1 \\
Fruit, fruit-peel and parts of plants, preserved by sugar & 16.08 & 3,218 & RB1 \\
Fish, prepared or preserved, nes & 14.91 & 5,528 & RB1 \\
Tires, pneumatic, new, for aircraft & 10.29 & 7,177 & RB1 \\
Articles of apparel, clothing accessories of plastic or rubber & 9.70 & 6,158 & LT1 \\
\hline Source UN COMTRADE
\end{tabular}

Source: UN COMTRADE

Figure 0.6: Global Share of Selected Thai Exports

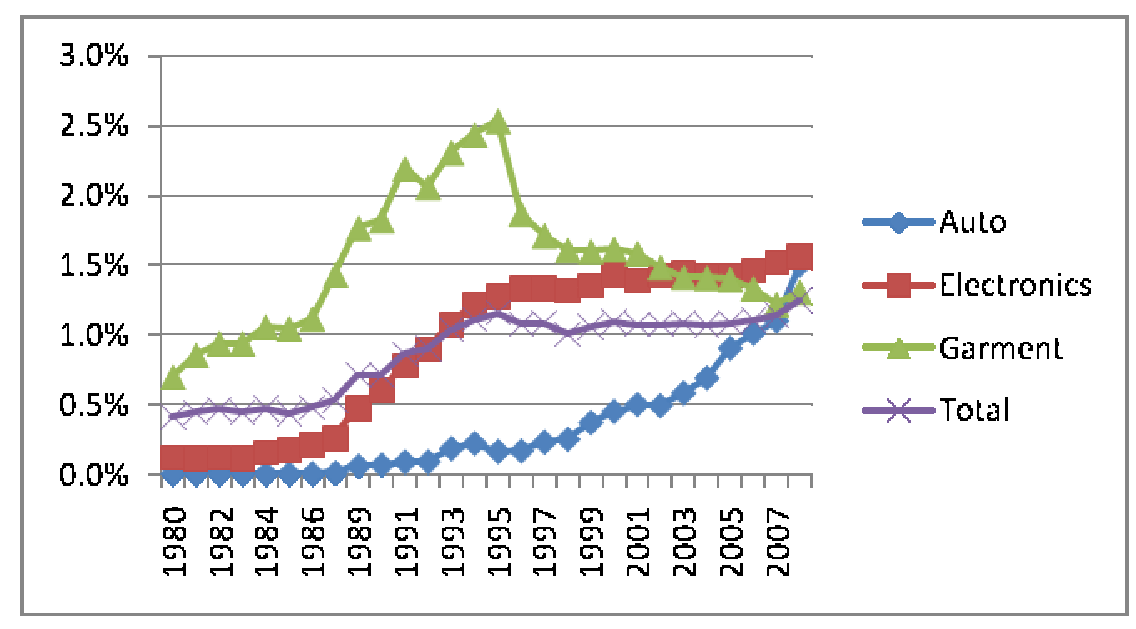

Source: Authors calculations using UNComtrade data

These statistics depict an economy with a dualistic manufacturing sector in which high tech activities, in particular transport equipment and electronics, coexist with the production of resource based manufactures, most notably foodstuffs, latex based products and gemstones and jewelry. However, a closer look at the electronics and auto industries reveals that Thailand, much like its neighbors Malaysia, Vietnam and Philippines, is mainly engaged in the labor intensive assembly, testing and packaging segments of the electronics business and the production of low value, standardized parts for the auto 
sector. The products assembled are classified as high-tech but there is little underlying technological capability. The diversification into electronics, electrical machinery and auto industries was achieved by attracting foreign direct investment (FDI) (see Figure $0.7) .^{28}$

Figure 0.7: Foreign direct investment, net inflows (BoP, current US\$ billions)

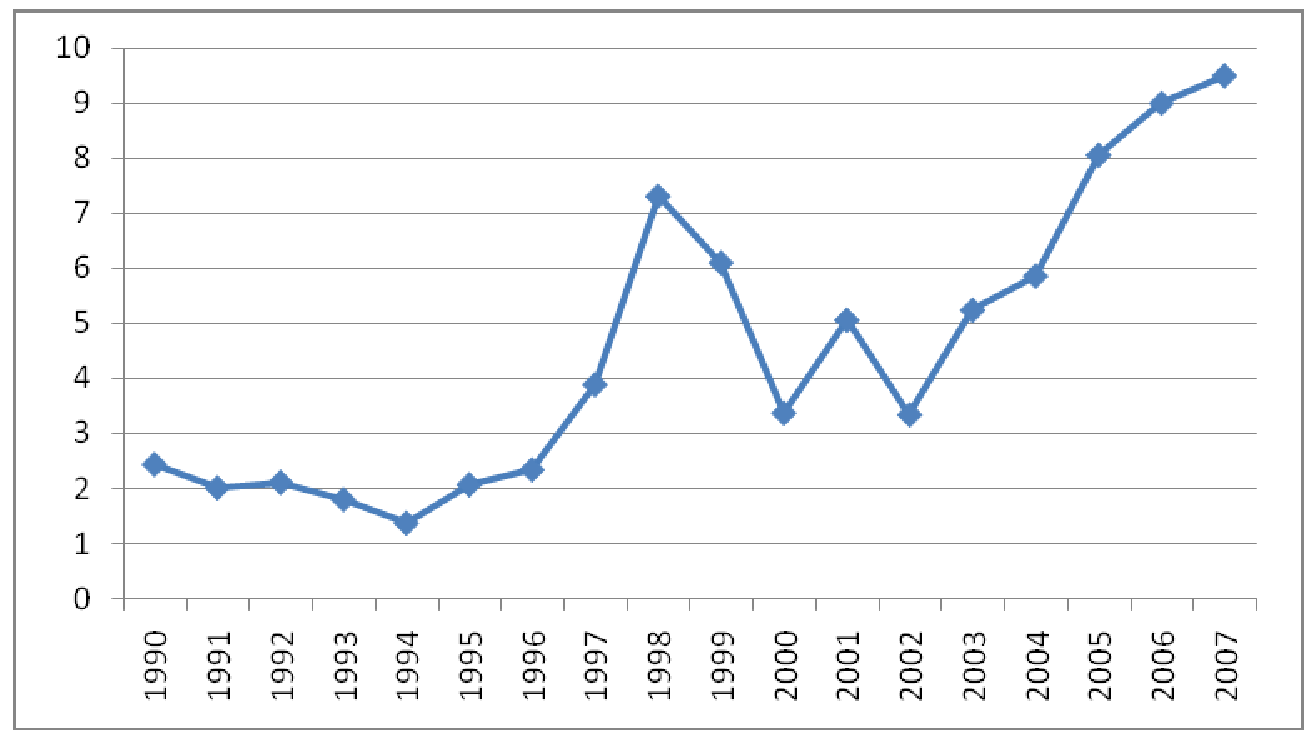

Source: World Development Indicators

Although the share of electronics and auto parts in Thailand's total exports is large, its comparative advantage based on domestic technological capabilities continues to reside in lower tech resource based products. Domestic value added in electronics and in transport industries is low and it largely unchanged since 2000. Production equipment and technology is imported and foreign companies are the dominant players. Moreover, even after two decades of electronics assembly, Thai owned companies have not significantly upgraded their product mix. Thailand's manufacturing and technological capabilities are those of a lower middle income country and although the product space analysis paints a positive picture, other evidence on investment, on RCA and on domestic technology development, suggests that technological deepening and industrial upgrading have a long way to go (see World Bank 2008 and Yusuf and Nabeshima 2009).

\section{Empirical Spadework for the Study}

There is plentiful evidence of industrial change most notably in the Bangkok region. The center of growth and manufacturing has shifted from the primary based industries to electronics and autos and these have also achieved prominence in Thailand's trade. But whether the manufacturing industry in the Bangkok region is on the road to technological

\footnotetext{
${ }^{28}$ For a detailed discussion on the industrial development and its future prospects in Malaysia, see Yusuf
} and Nabeshima (2010). 
deepening that will lead to significant gains in productivity and to innovation remains to be decided. A closer integration of industry and services throughout the metro region and clustering virtual or other, has the potential of generating the synergies that would bring about the technological and growth outcomes Thailand needs to secure its medium term development objectives.

To this end, we commissioned surveys of manufacturing firms, services providers and of developers active in the Bangkok metro area. The two groups surveyed were manufacturing firms and industrial estate developers. The group of 88 industrial producers included 27 from the food industry, 30 from the automotive industry and 31 from the electronics industry. The interviews of the first group covered questions on: choice of location, labor availability and quality, technology acquisition, purchases of business services and the use of IT. The second group comprised of 8 industrial estate developers was interviewed about their roles in urban and regional developments. The size of the firms in the surveys varied, from those earning less than 50 million Baht annually to those earning more than 2,000 million Baht. The companies in the food industry were mostly $100 \%$ Thai-owned, electronics companies were mainly owned either wholly or partially by multinational companies, and the automotive industry was split equally between Thai and foreign ownership (TDRI 2009).

From across the spectrum of industries in Bangkok and the vicinity we selected the food, garment and textiles, auto parts, and electronics subsectors because they are large, exportoriented and straddle all three levels of technology. In addition, we looked at the metal working industry, which is a backbone of manufacturing activities. For the services industry, we use printing and publishing as the main indicator of growth of services industry in Bangkok. The experience of other countries points to the significance of printing and publishing industry for large metropolitan areas (Yusuf and Nabeshima 2010).

GIS maps of establishments, number of workers, and investments were created using district level data from the industrial works department for 1997 and 2007. The output maps were created using the data from the industrial census at the provincial levels for the same two years. 


\section{The Evolution of Industrial Activities in Bangkok}

International experience indicates that as an urban economy matures, manufacturing activities move from the core of the city to the fringe areas where land is cheaper and gradually the composition of economic activities within the core city area shifts towards services $^{29}$. If clustering tendencies are strong particular types of industries can form clusters in specialized secondary cities within the urban region.

\section{Share of Industrial activities in Bangkok and the vicinity}

Bangkok and its vicinity ${ }^{30}$ accounts for almost one half of Thailand's industrial output. Its share of industrial output has decreased 9 percentage points from 1997 to 2007 (see Table 0.1). This decline affects most subsectors. Bangkok's share of the national output of food products, metal products, electronics and auto parts, are all decreasing (see Table 0.2 ). This pattern is in conformity with the industrial life cycle of major cities.

Table 0.1: Bangkok and vicinity's share of national total in manufacturing

\begin{tabular}{lcrr}
\hline & $\begin{array}{c}\text { Number of } \\
\text { Establishments }\end{array}$ & $\begin{array}{c}\text { Number of } \\
\text { Employees }\end{array}$ & $\begin{array}{c}\text { Value of Gross } \\
\text { Outputs (in } \\
\text { thousand baht) }\end{array}$ \\
\hline $\mathbf{1 9 9 7}$ & 14,098 & $1,444,610$ & $2,052,091,887.60$ \\
Bangkok and Vicinity & 23,677 & $2,413,325$ & $3,541,257,252$ \\
Whole Kingdom & $\mathbf{5 9 . 5 \%}$ & $\mathbf{5 9 . 9 \%}$ & $\mathbf{5 7 . 9 \%}$ \\
Share & & & \\
$\mathbf{2 0 0 7}$ & 67,454 & $1,974,097$ & $3,571,142,012.00$ \\
Bangkok and Vicinity & 457,968 & $3,818,955$ & $7,304,513,965.70$ \\
Whole Kingdom & $\mathbf{1 4 . 7 \%}$ & $\mathbf{5 1 . 7 \%}$ & $\mathbf{4 8 . 9 \%}$ \\
Share & & & \\
\hline
\end{tabular}

Source: National Statistics Office

\footnotetext{
${ }^{29}$ See Webster (2004) on the peri-urban development around Bangkok.

${ }^{30}$ Vicinity includes the provinces of Chon Buri, Chachoengsao, Nonthaburi, Pra Nakhon Si Ayudhaya, Pathum Thani, Rayong, Samut Prakarn, and Samut Sakhon.
} 
Table 0.2: Bangkok and vicinity's share of national total in manufacturing, by industrial subsector

\begin{tabular}{|c|c|c|c|}
\hline Industrial Subsector & $\begin{array}{c}\text { Number of } \\
\text { Establishments }\end{array}$ & $\begin{array}{l}\text { Number of } \\
\text { Employees } \\
\end{array}$ & $\begin{array}{c}\text { Value of Gross } \\
\text { Outputs }\end{array}$ \\
\hline \multicolumn{4}{|l|}{1997} \\
\hline $\begin{array}{l}\text { Manufacture of food } \\
\text { products and beverages }\end{array}$ & $29.0 \%$ & $44.2 \%$ & $45.3 \%$ \\
\hline Manufacture of textiles & $75.7 \%$ & $73.8 \%$ & $68.0 \%$ \\
\hline $\begin{array}{l}\text { Manufacture of radio, } \\
\text { television and } \\
\text { communication equipment } \\
\text { and apparatus }\end{array}$ & $60.9 \%$ & $52.6 \%$ & $39.9 \%$ \\
\hline $\begin{array}{l}\text { Manufacture of motor } \\
\text { vehicles, trailers and semi- } \\
\text { trailers }\end{array}$ & $63.8 \%$ & $71.9 \%$ & $81.4 \%$ \\
\hline \multicolumn{4}{|l|}{2007} \\
\hline $\begin{array}{l}\text { Manufacture of food } \\
\text { products and beverages }\end{array}$ & $4.2 \%$ & $43.4 \%$ & $49.4 \%$ \\
\hline Manufacture of textiles & $3.5 \%$ & $53.2 \%$ & $71.2 \%$ \\
\hline $\begin{array}{l}\text { Manufacture of radio, } \\
\text { television and } \\
\text { communication equipment } \\
\text { and apparatus }\end{array}$ & $55.5 \%$ & $38.5 \%$ & $19.5 \%$ \\
\hline $\begin{array}{l}\text { Manufacture of motor } \\
\text { vehicles, trailers and semi- } \\
\text { trailers }\end{array}$ & $58.5 \%$ & $47.0 \%$ & $60.6 \%$ \\
\hline
\end{tabular}

Source: National Statistics Office

In the majority of industrial subsectors, labor productivity increased between 1997 and 2007, with the increase being greatest in industries producing office machines and basic metals. In contrast, labor productivity in food and publishing almost halved during this period (Table 0.3). On average, there were more industrial subsectors in the Bangkok vicinity registering an increase in labor productivity compared to Bangkok (see Table 0.4). Labor productivity in Bangkok was higher in only five industrial subsectors: textiles; publishing; metal working; office machines; and telecommunication apparatus. 
Table 0.3: Labor Productivity in Bangkok

\begin{tabular}{|c|c|c|c|}
\hline & 1997 & 2007 & $\begin{array}{c}\% \text { Change of } \\
\text { Labor } \\
\text { Productivity }\end{array}$ \\
\hline Manufacture of food products and beverages & 853.8 & 364.1 & $-57.4 \%$ \\
\hline Manufacture of textiles & 248.0 & 354.5 & $42.9 \%$ \\
\hline $\begin{array}{l}\text { Manufacture of wearing apparel; dressing and dyeing of } \\
\text { fur }\end{array}$ & 154.1 & 205.7 & $33.5 \%$ \\
\hline $\begin{array}{l}\text { Tanning and dressing of leather; manufacture of } \\
\text { luggage, handbags, saddlery, harness and footwear }\end{array}$ & 212.1 & 205.2 & $-3.2 \%$ \\
\hline $\begin{array}{l}\text { Publishing, printing and reproduction of recorded } \\
\text { media }\end{array}$ & 713.9 & 324.1 & $-54.6 \%$ \\
\hline Manufacture of basic metals & 458.3 & 922.9 & $101.4 \%$ \\
\hline $\begin{array}{l}\text { Manufacture of fabricated metal products, except } \\
\text { machinery and equipment }\end{array}$ & 219.4 & 316.3 & $44.2 \%$ \\
\hline $\begin{array}{l}\text { Manufacture of office, accounting and computing } \\
\text { machinery }\end{array}$ & 296.8 & $3,914.5$ & $1218.7 \%$ \\
\hline $\begin{array}{l}\text { Manufacture of electrical machinery and apparatus } \\
\text { n.e.c. }\end{array}$ & 288.6 & 334.8 & $16.0 \%$ \\
\hline $\begin{array}{l}\text { Manufacture of radio, television and communication } \\
\text { equipment and apparatus }\end{array}$ & 563.2 & 497.4 & $-11.7 \%$ \\
\hline $\begin{array}{l}\text { Manufacture of motor vehicles, trailers and semi- } \\
\text { trailers }\end{array}$ & 615.1 & $1,134.0$ & $84.4 \%$ \\
\hline
\end{tabular}

Source: National Statistics Office 


\begin{tabular}{|c|c|c|c|}
\hline & 1997 & 2007 & $\begin{array}{r}\% \text { Change of } \\
\text { Labor } \\
\text { Productivity }\end{array}$ \\
\hline Manufacture of food products and beverages & 306.8 & 509.3 & $66.0 \%$ \\
\hline $\begin{array}{l}\text { Manufacture of textiles } \\
\text { Manufacture of wearing apparel; dressing and dyeing of } \\
\text { fur }\end{array}$ & 188.4 & 256.6 & $36.2 \%$ \\
\hline $\begin{array}{l}\text { Tanning and dressing of leather; manufacture of } \\
\text { luggage, handbags, saddlery, harness and footwear } \\
\text { Publishing, printing and reproduction of recorded } \\
\text { media }\end{array}$ & 149.2 & 324.1 & $117.2 \%$ \\
\hline Manufacture of basic metals & 331.7 & 668.0 & $101.4 \%$ \\
\hline $\begin{array}{l}\text { Manufacture of fabricated metal products, except } \\
\text { machinery and equipment }\end{array}$ & 315.5 & 406.2 & $28.7 \%$ \\
\hline $\begin{array}{l}\text { Manufacture of office, accounting and computing } \\
\text { machinery } \\
\text { Manufacture of electrical machinerv and anparatus }\end{array}$ & 702.8 & 634.8 & $-9.7 \%$ \\
\hline $\begin{array}{l}\text { Manufacture of electrical machinery and apparatus } \\
\text { n.e.c. }\end{array}$ & 507.4 & 476.5 & $-6.1 \%$ \\
\hline $\begin{array}{l}\text { Manufacture of radio, television and communication } \\
\text { equipment and apparatus }\end{array}$ & 351.8 & 353.1 & $0.4 \%$ \\
\hline $\begin{array}{l}\text { Manufacture of motor vehicles, trailers and semi- } \\
\text { trailers }\end{array}$ & 2047.3 & 2258.3 & $10.3 \%$ \\
\hline
\end{tabular}

Source: National Statistics Office

\section{Auto Parts Industry}

One way to visualize the changing distribution of industrial activities in the Bangkok area is to overlay economic activities on a map. Figure 0.1 to Figure 0.7 show changes in various indicators for the auto parts sector in the Bangkok area. In 1997, auto parts firms were mainly concentrated in Bangkok and in the province of Samut Prakarn, which lie directly south of Bangkok. By 2007, auto parts firms had dispersed along the coastal areas to the east away from Bangkok (see Figure 0.1, Figure 0.2, and Figure 0.3). In 10 years, 89 firms were established in Chonburi, while there were 134 fewer firms in Bangkok. Other provinces such as Samut Sakhon, Ayutthaya, Chachoengsao, and Rayong also saw the number of auto parts firms increase, especially in the Pluagdeang district. In all, the number of establishments belonging to this important industry in the Bangkok vicinity almost doubled over a ten year period (see Table 0.5).

In parallel with the increase in the number of establishments, investment and employment also rose outside of the Bangkok area (see Figure 0.4 and Figure 0.5), although the increase in employment was not as large as in the number of establishments (see Table 0.5). The auto sector employs a mix of skilled and semi-skilled workers, with the auto 
components manufacturing activities employing a higher percentage of skilled workers. As a result of the spatial redistribution of the auto industry, more of the larger scale but less skill intensive activities have remained in Bangkok while the newer more specialized, skill using ones on which the future of the industry rests, have transferred to the outer provinces of the urban region. Thus, $75 \%$ of the auto industry workforce in Bangkok is now classified as skilled as against $77 \%$ for the nation as a whole. However, in Chachoengsao and Rayong almost $85 \%$ of the workers are skilled. Because most of the firms exiting the industry in Bangkok were small firms, the output did not see much change (see Figure 0.6). In Samut Sakhon, Samut Prakarn, Chachoengsao, Chonburi, and Rayong, the output rose along with an increase in employment, investment, and the number of establishments. The most striking development was in Ayutthaya and Pathum Thani, where the output increased greatly as a result of the establishment of a few large production establishments. These changes are encouraging signs of the maturing of a key industry and the possible emergence of automobile clusters as this is an activity which benefits from the contiguity of suppliers and assemblers.

Table 0.5: Changes in Auto Parts Industry, 1997-2007 (values in thousand baht)

\begin{tabular}{|c|c|c|c|c|}
\hline & 1997 & 2007 & Change (\%) & $\begin{array}{l}\text { Average } \\
\text { Growth (\%) }\end{array}$ \\
\hline \multicolumn{5}{|l|}{ Bangkok } \\
\hline Number of Establishments & 459 & 325 & $-29.2 \%$ & -3.45 \\
\hline Number of Employees & 30,167 & 19,761 & $-34.5 \%$ & -4.23 \\
\hline Value of Gross Outputs & $103,644,148$ & $104,465,836$ & $0.8 \%$ & 0.08 \\
\hline Book Value of Fixed Assets & $29,215,868$ & $23,430,412$ & $-19.8 \%$ & -2.21 \\
\hline \multicolumn{5}{|l|}{ Vicinity } \\
\hline Number of Establishments & 240 & 457 & $90.4 \%$ & 6.44 \\
\hline Number of Employees & 46,956 & 54,794 & $16.7 \%$ & 1.54 \\
\hline Value of Gross Outputs & $275,908,646$ & $389,297,929$ & $41.1 \%$ & 3.44 \\
\hline Book Value of Fixed Assets & $63,239,637$ & $127,292,252$ & $101.3 \%$ & 7.00 \\
\hline \multicolumn{5}{|l|}{ National Total } \\
\hline Number of Establishments & 1,095 & 1,336 & $22.0 \%$ & 1.99 \\
\hline Number of Employees & 107,222 & 158,581 & $47.9 \%$ & 3.91 \\
\hline Value of Gross Outputs & $466,263,629$ & $815,326,993$ & $74.9 \%$ & 5.59 \\
\hline Book Value of Fixed Assets & $139,208,123$ & $331,328,270$ & $138.0 \%$ & 8.67 \\
\hline
\end{tabular}


Figure 0.1: Number of establishments in auto sectors at province level
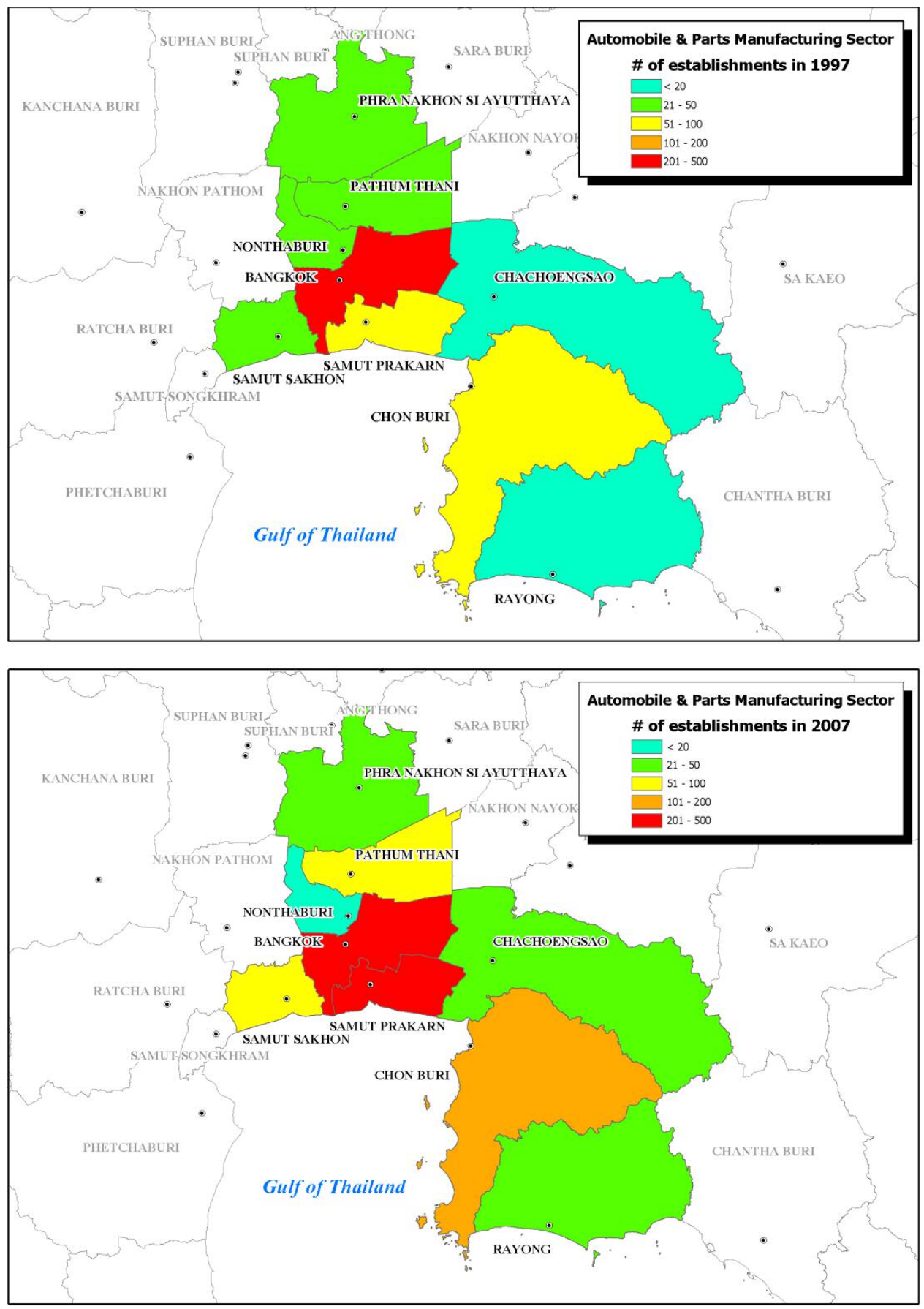
Figure 0.2: Number of establishments in auto sectors at district level
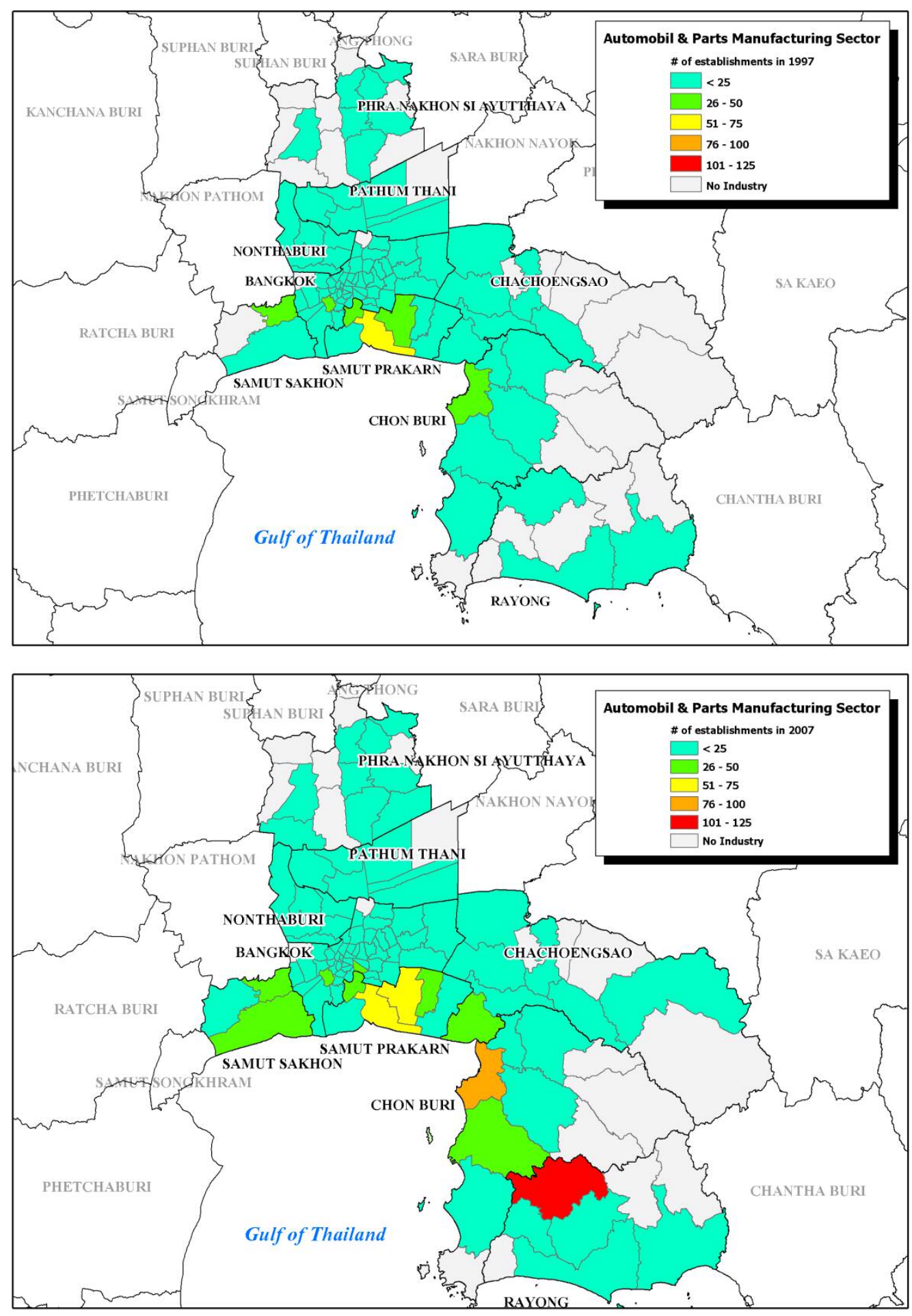
Figure 0.3: New entry in auto parts sector

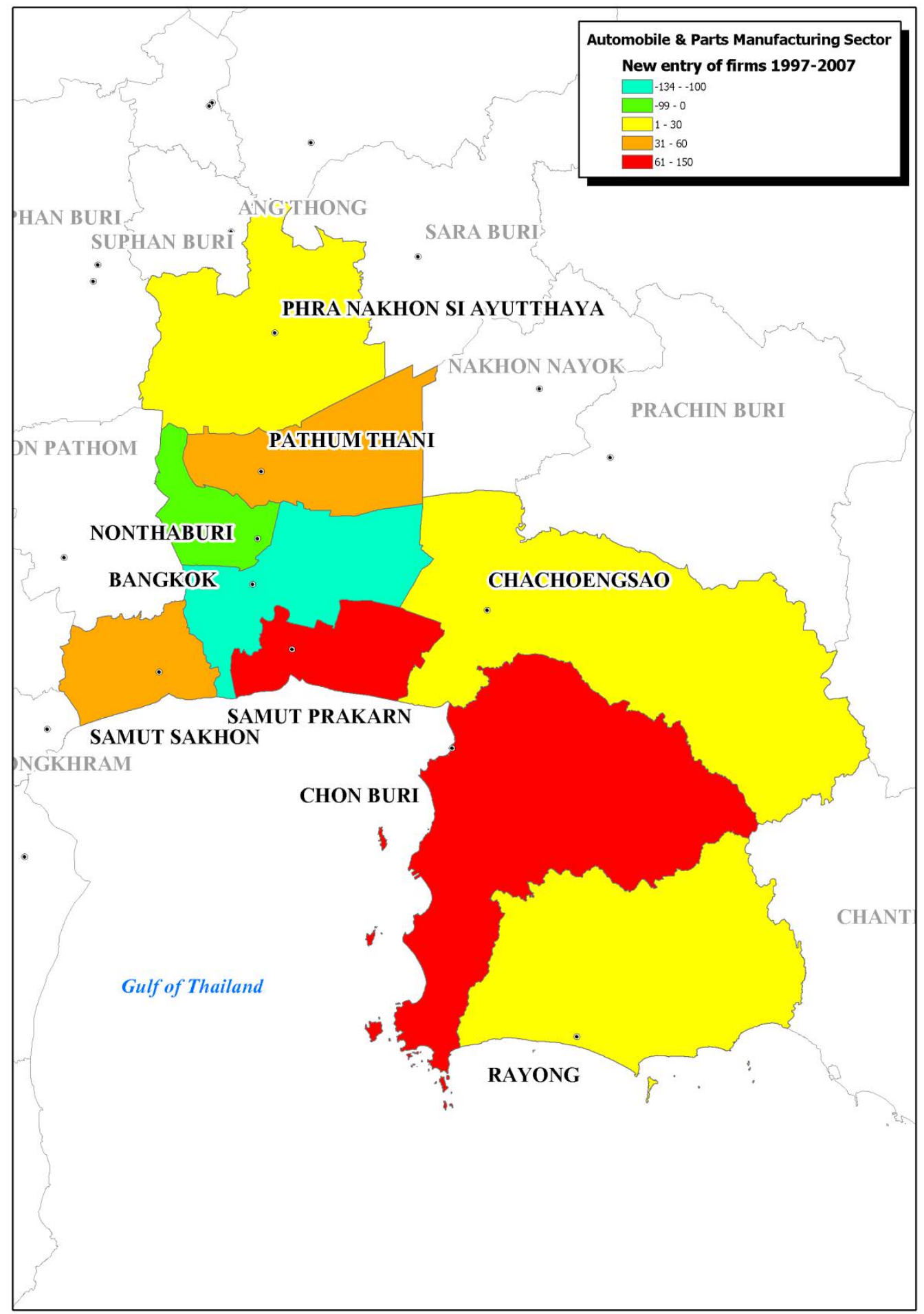


Figure 0.4: Employment in auto parts sector
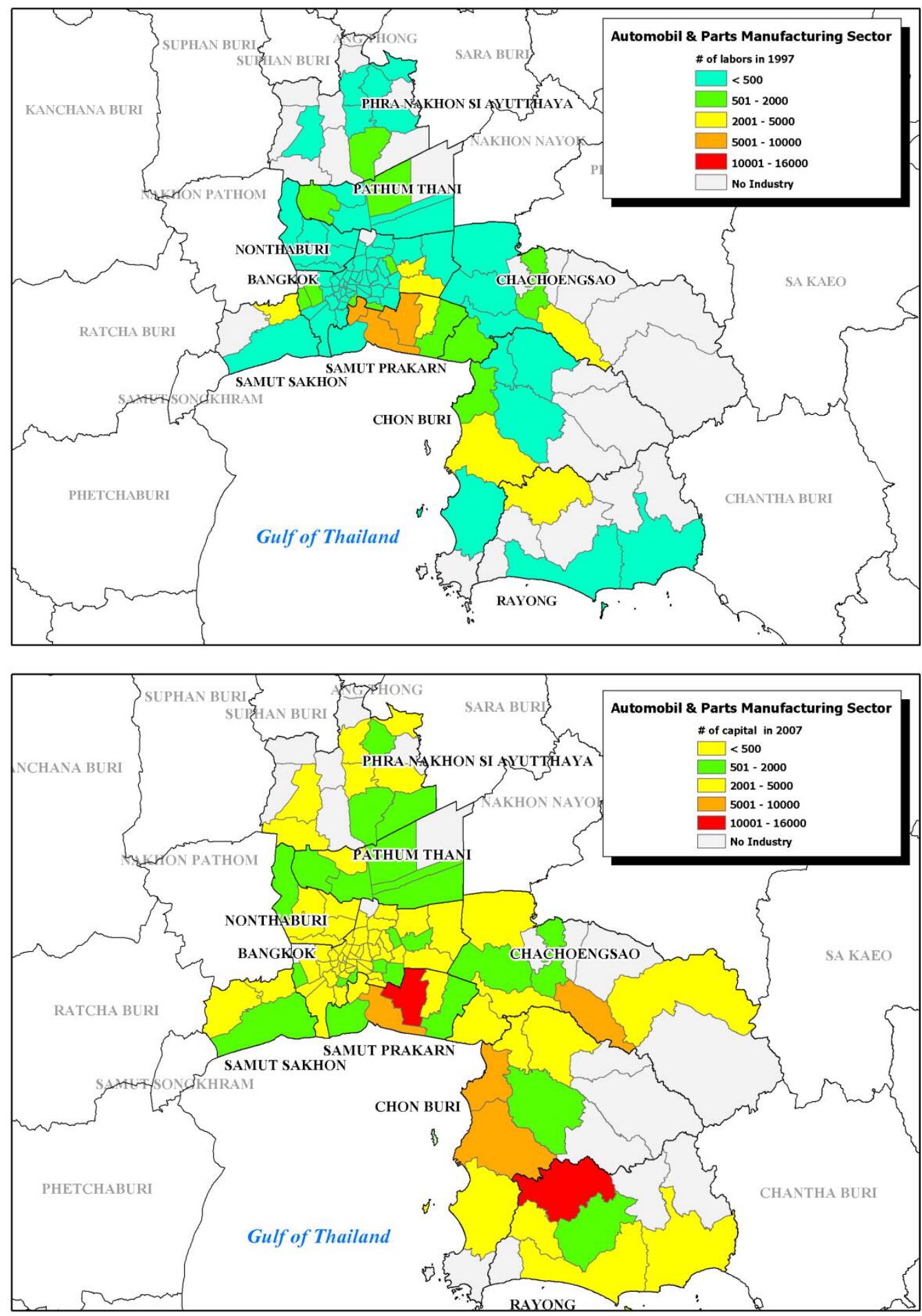
Figure 0.5: Investments in auto parts sector
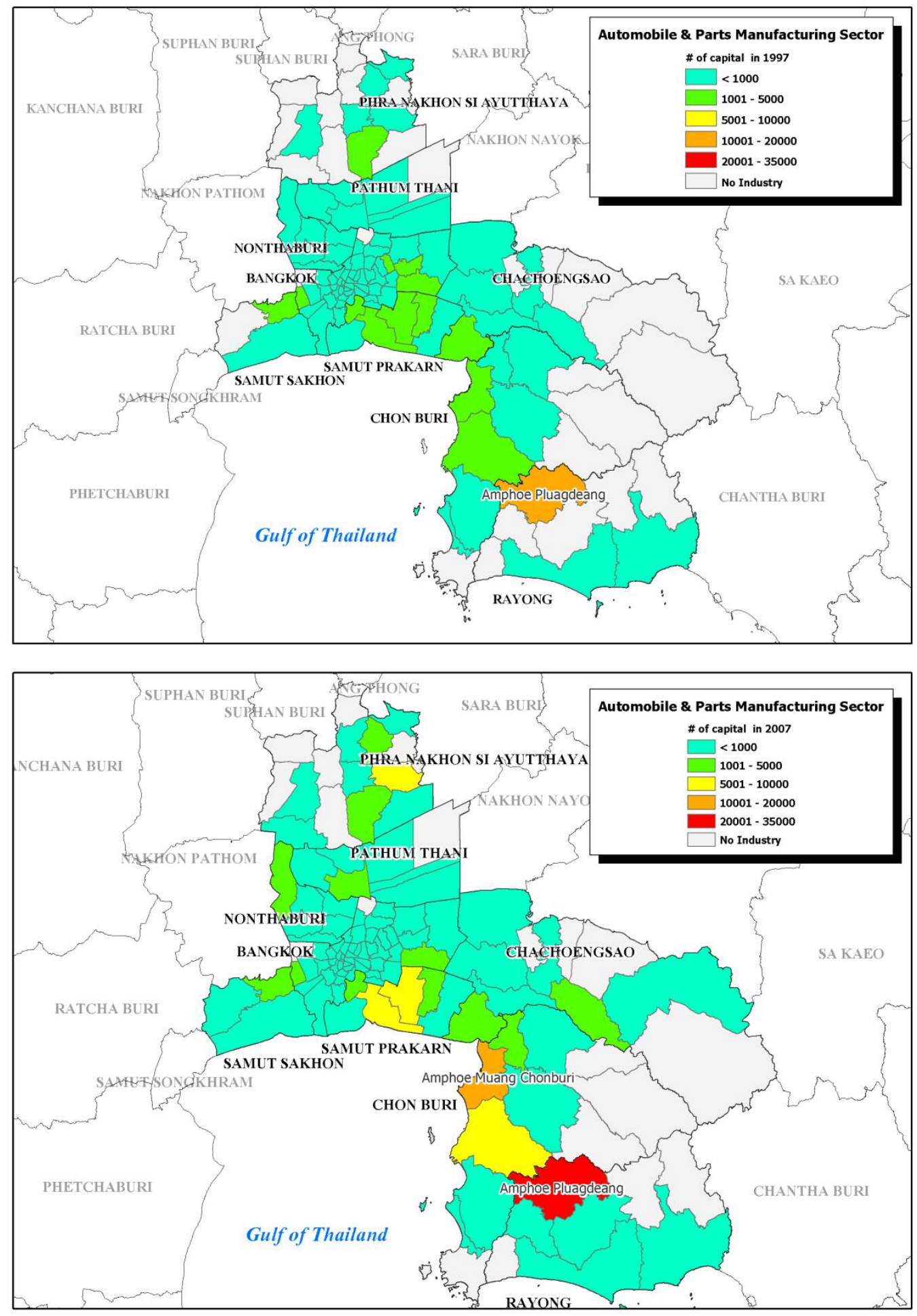
Figure 0.6: Gross outputs in auto parts sector
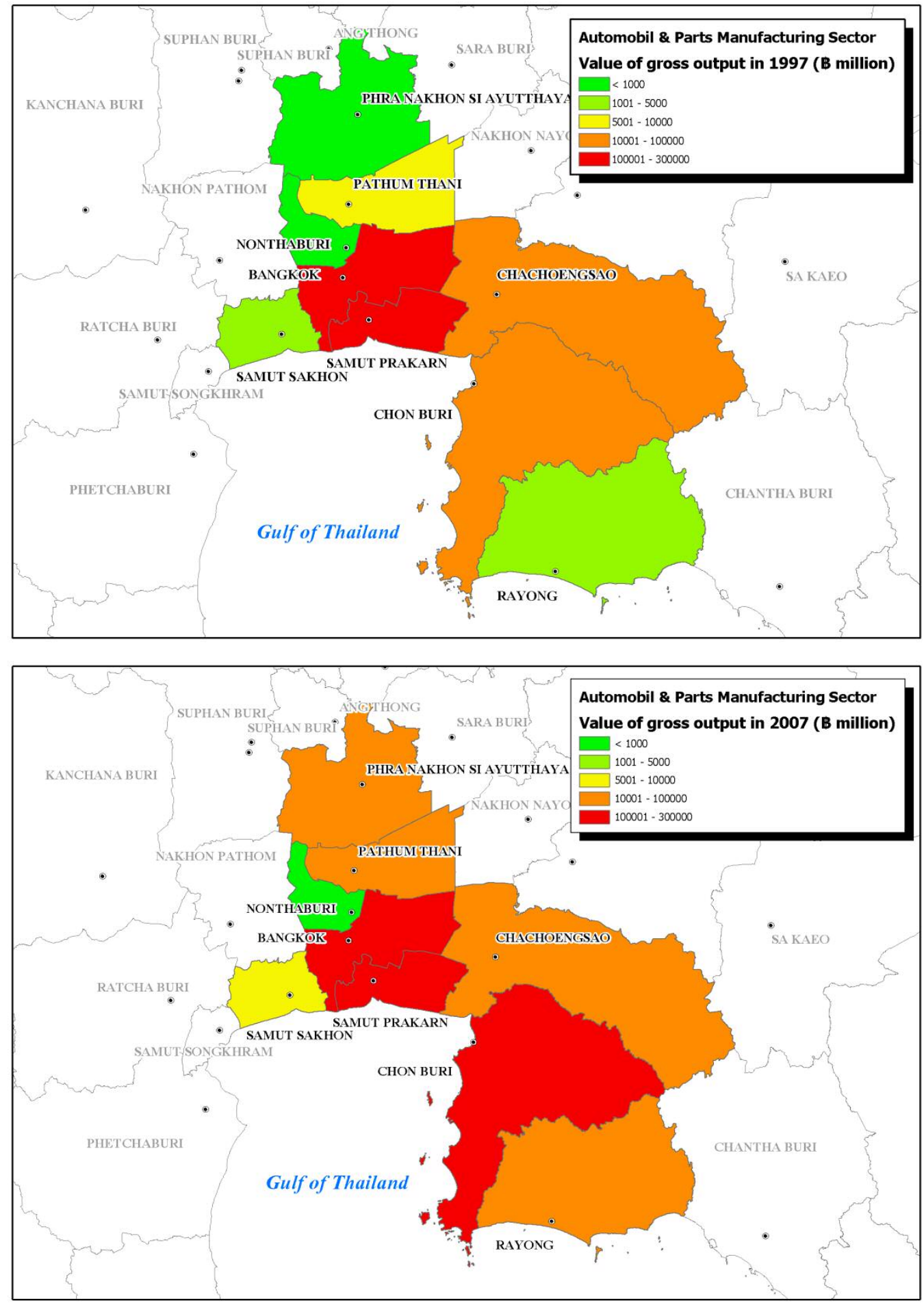
Figure 0.7: Skill composition in auto parts sector

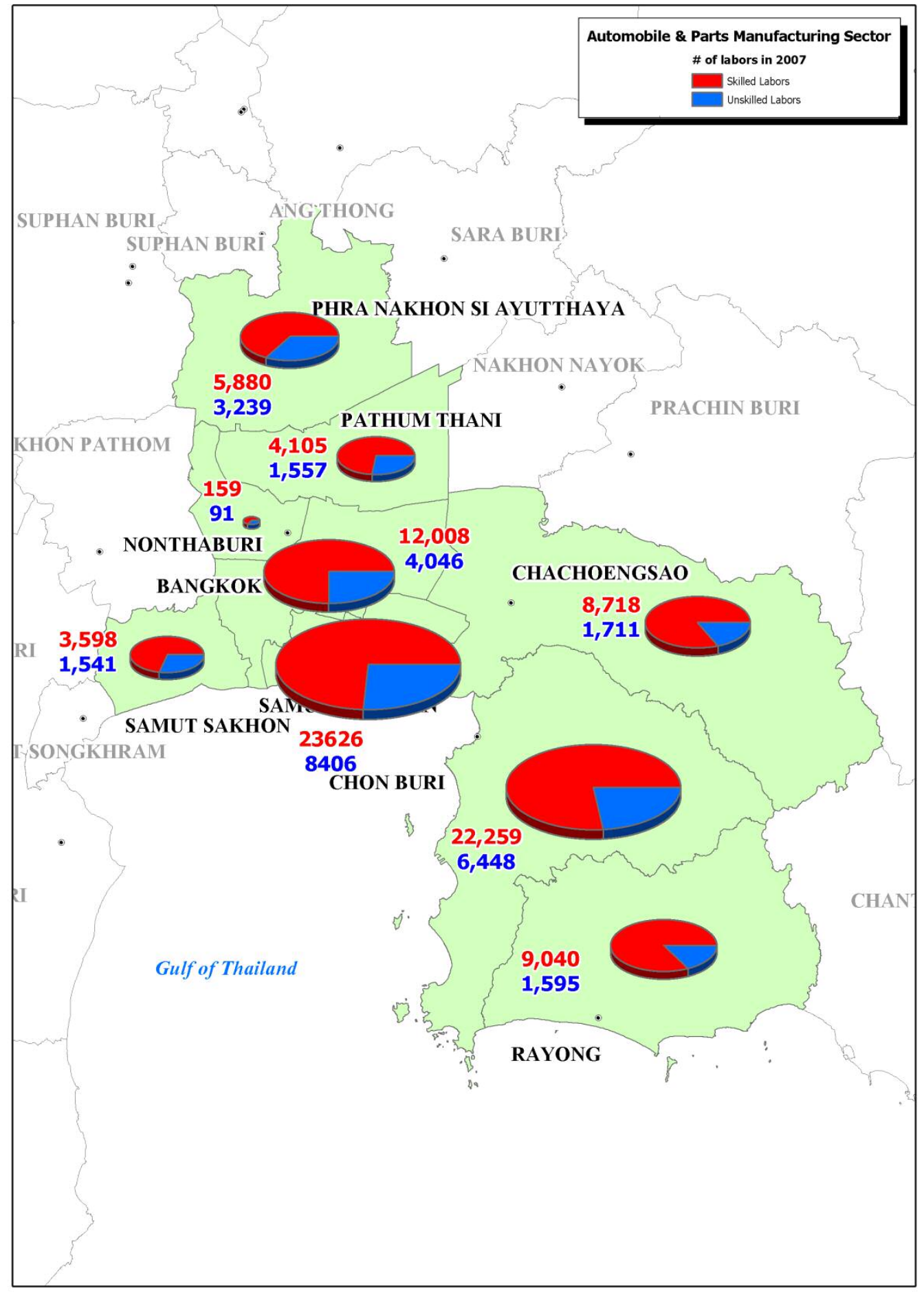




\section{Electronics Industry}

The electronics industry remains active in the core area of Bangkok but it too is expanding in the direction of Pathum Thani and Ayutthaya to the north, and Samut Prakarn to the south (see Figure 0.8). Relative to 1997, the number of electronics firms increased by 93 in Ayutthaya, 22 in Samut Sakhon, and 43 in Chonburi (see Figure 0.9). During this period, 84 firms were established in Bangkok as well. A shift in the center of gravity of the industry is apparent from the relative distribution of new production facilities. New firms in the vicinity (i.e. in the region as a whole) increased from 86 in 1997 to 263 in 2007 (see Table 0.6). A closer examination of location choices reveals two distinct patterns. The first is a concentration of firms along the coast to take advantage of the access to ports because relatively bulky electronic appliances are a major export item. The second is the concentration of producers in Ayutthaya and Pathum Thani. In Ayutthaya, electronic appliance firms are clustered in just two districts, Bang Pa-in and Uthai, and in Pathum Thani, Khlong Luang (see Figure 0.10).

The increase in the number of firms in Ayutthaya, went hand in hand with rising gross output, investment, and employment between 1997 and 2007 (see Figure 0.11, Figure 0.12 , and Figure 0.13). What is curious (and this may be a statistical quirk) is that the gross output from Chonburi decreased despite the increase in the number of firms, employment, and investment.

Compared with the skill distribution in the auto parts sector, the skill distribution in electronics industry is more varied pointing to the different levels of sophistication of the products produced. These range from simple consumer electricals to household appliances to electronic components some involving straight forward assembly, others calling for more skillful manufacturing under tightly controlled conditions (e.g. hard disk drives). In comparison with auto manufacturing, the electronics industry appears to be still at the stage of assembling standardized products based on codified technologies. Nevertheless it is notable that concentrations of high-tech activity are beginning to appear. The most skill intensive area is Chachoengsao with $98 \%$ of the workforce comprised of skilled workers, followed by Samut Sakhon with $89 \%$ and Rayong with $77 \%$. The national average for the electronics industry is 72 percent. The share of skilled workers in Bangkok was only 62\%, in Ayutthaya it was $61 \%$ and in Chonburi, 68\%. This distribution is very likely an outcome of FDI in these provinces. MNCs typically hire more skilled workers relative to domestic firms (Yilmaz 2009) and they may be concentrating their higher end production in Chachoengsao and in Samut Sakhon.

The electronics industry has grown in both Bangkok and its vicinity but its share of the national output, employment and establishments fell between 1997 and 2007 suggesting a move away from the traditional production centers to new ones to the north of Bangkok. 
However, signs of increased clustering are visible in Ayuthaya and continuing growth in Bangkok points to the robustness of established producers (see Table 0.6).

Table 0.6: Changes in Electronics Industry, 1997-2007 (values in thousand baht)

\begin{tabular}{|c|c|c|c|c|}
\hline & 1997 & 2007 & Change (\%) & $\begin{array}{l}\text { Average } \\
\text { Growth (\%) }\end{array}$ \\
\hline \multicolumn{5}{|l|}{ Bangkok } \\
\hline Number of Establishments & 71 & 155 & $118.3 \%$ & 7.81 \\
\hline Number of Employees & 15,654 & 19,693 & $25.8 \%$ & 2.30 \\
\hline Value of Gross Outputs & $27,779,863$ & $43,567,111$ & $56.8 \%$ & 4.50 \\
\hline Book Value of Fixed Assets & $11,839,813$ & $16,004,462$ & $35.2 \%$ & 3.01 \\
\hline \multicolumn{5}{|l|}{ Vicinity } \\
\hline Number of Establishments & 86 & 263 & $205.8 \%$ & 11.18 \\
\hline Number of Employees & 43,926 & 91,833 & $109.1 \%$ & 7.37 \\
\hline Value of Gross Outputs & $81,038,956$ & $139,260,268$ & $71.8 \%$ & 5.41 \\
\hline Book Value of Fixed Assets & $32,330,294$ & $66,937,864$ & $107.0 \%$ & 7.28 \\
\hline \multicolumn{5}{|l|}{ National Total } \\
\hline Number of Establishments & 258 & 753 & $191.9 \%$ & 10.71 \\
\hline Number of Employees & 113,328 & 289,768 & $155.7 \%$ & 9.39 \\
\hline Value of Gross Outputs & $203,222,517$ & $937,071,430$ & $361.1 \%$ & 15.28 \\
\hline Book Value of Fixed Assets & $143,955,671$ & $228,764,125$ & $58.9 \%$ & 4.63 \\
\hline
\end{tabular}


Figure 0.8: Number of firms in electronics at province level
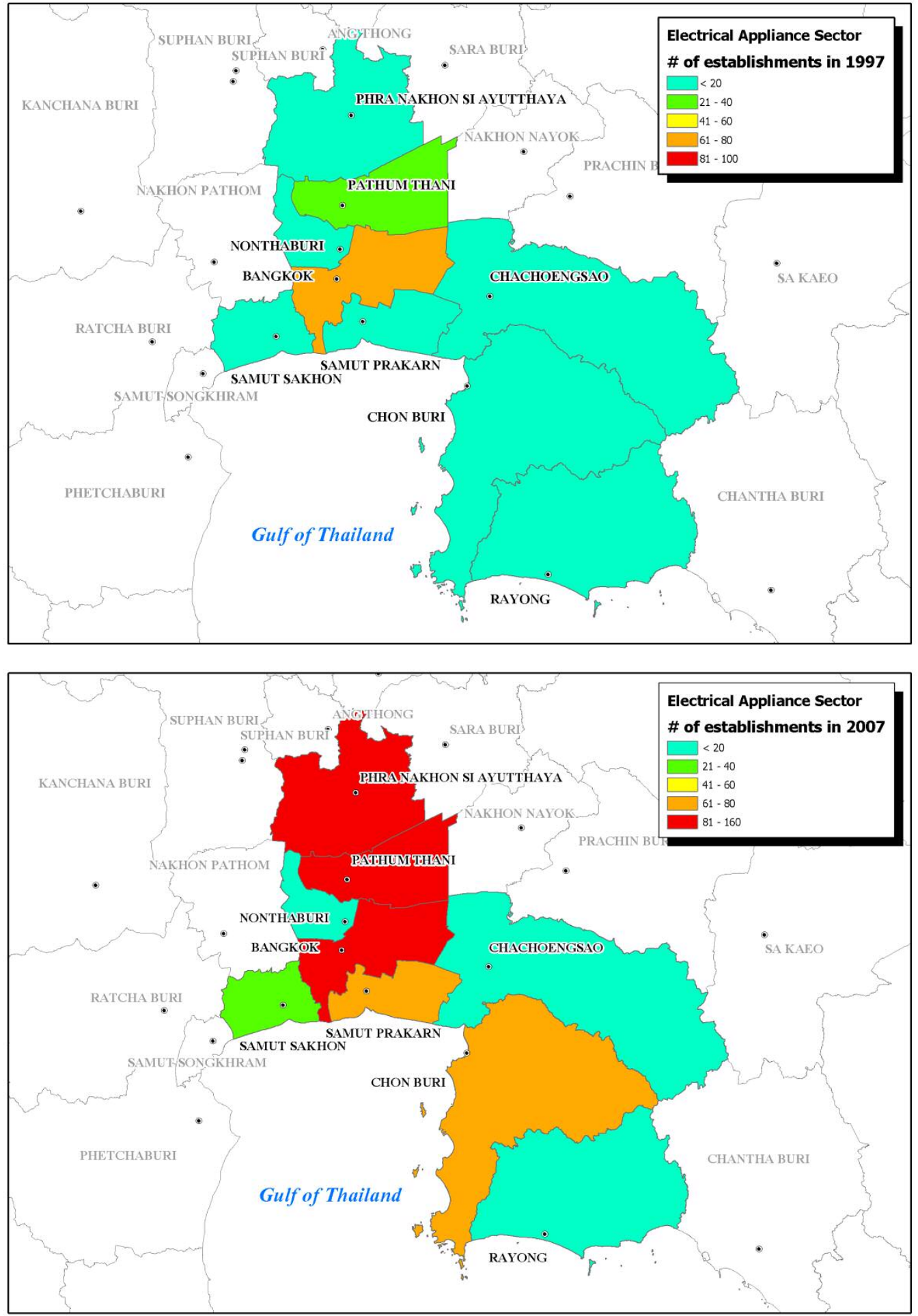
Figure 0.9: New entry in electronics

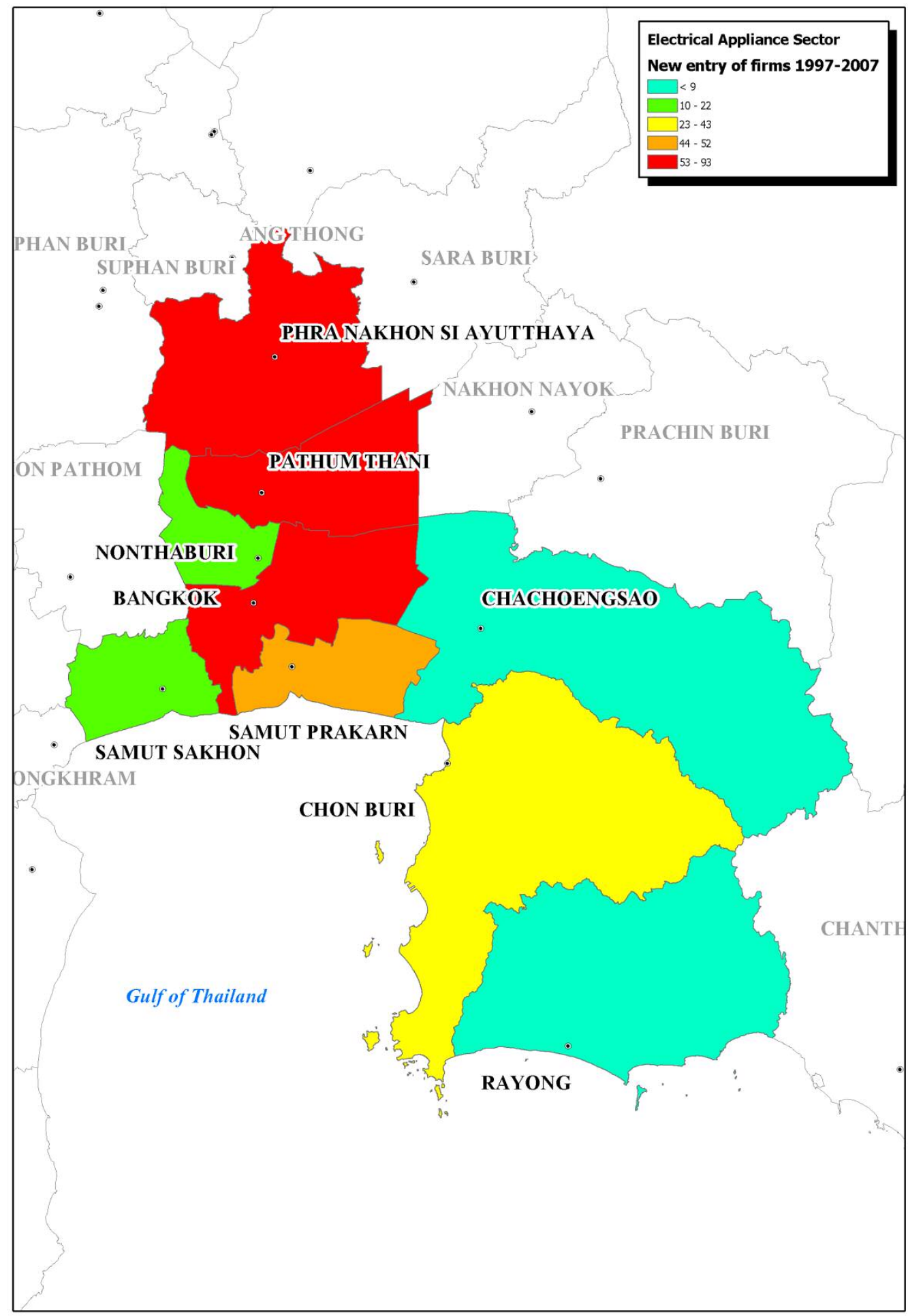


Figure 0.10: Number of firms in electronics at district level
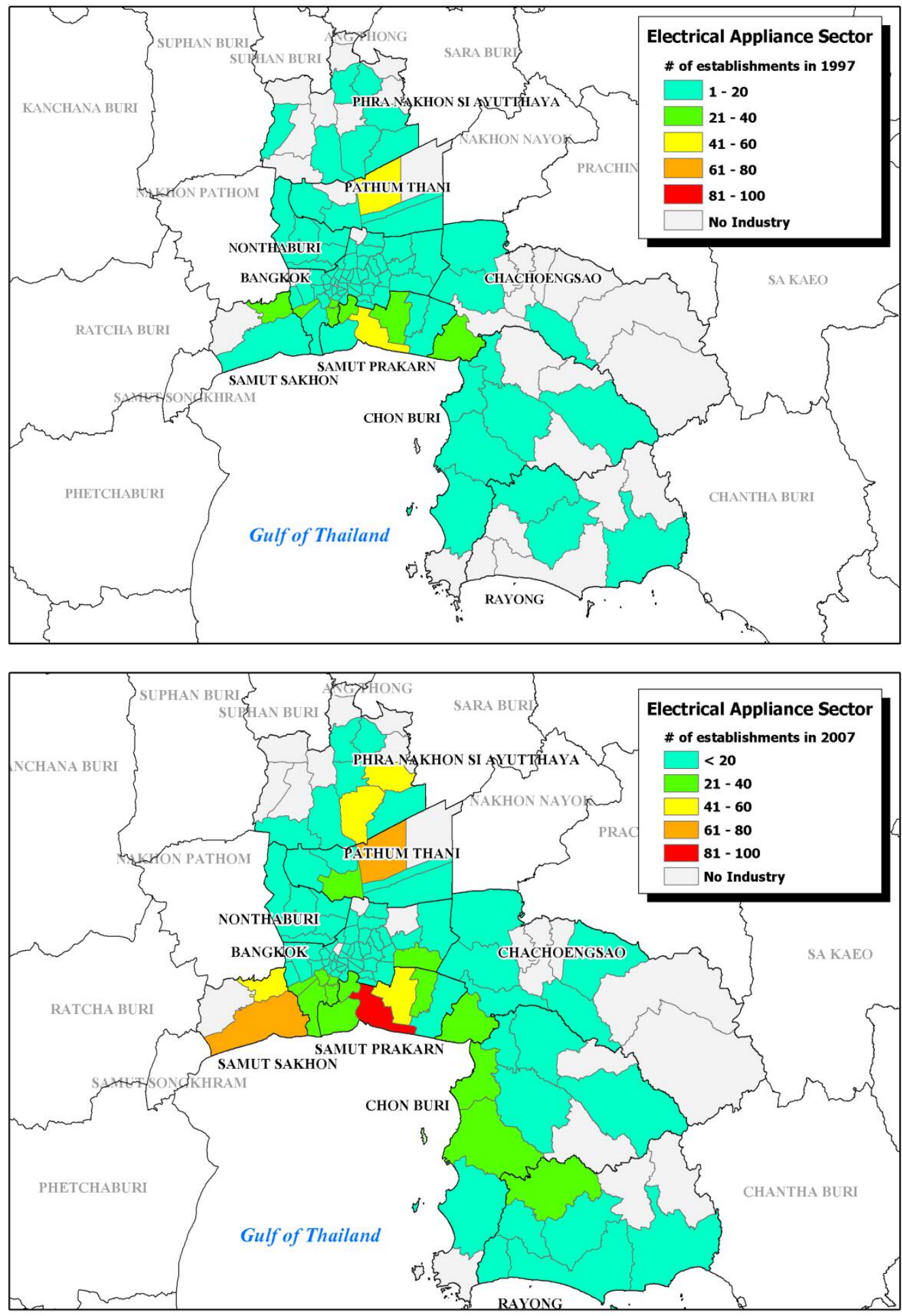
Figure 0.11: Gross outputs in electronics
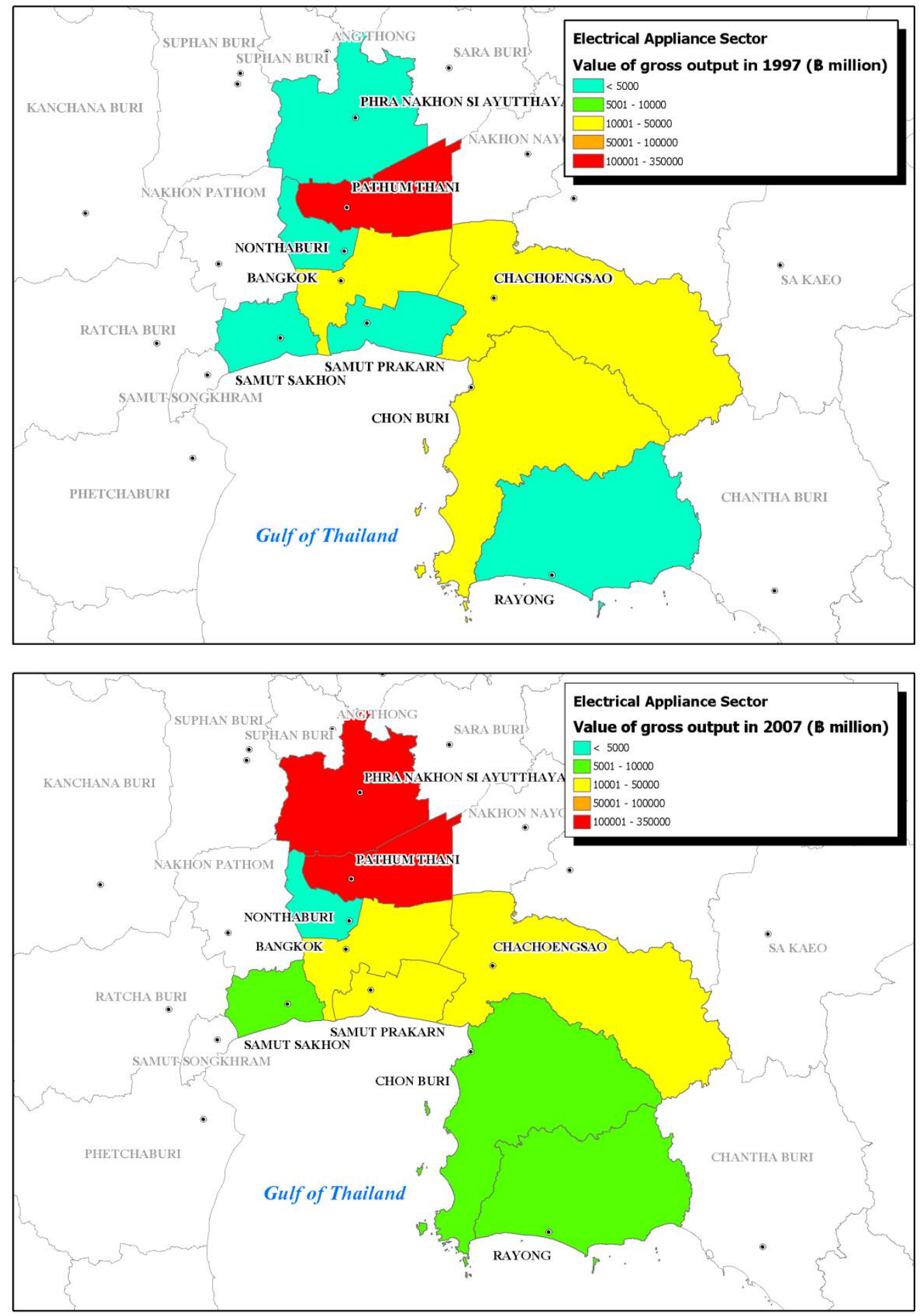
Figure 0.12: Employment in electronics
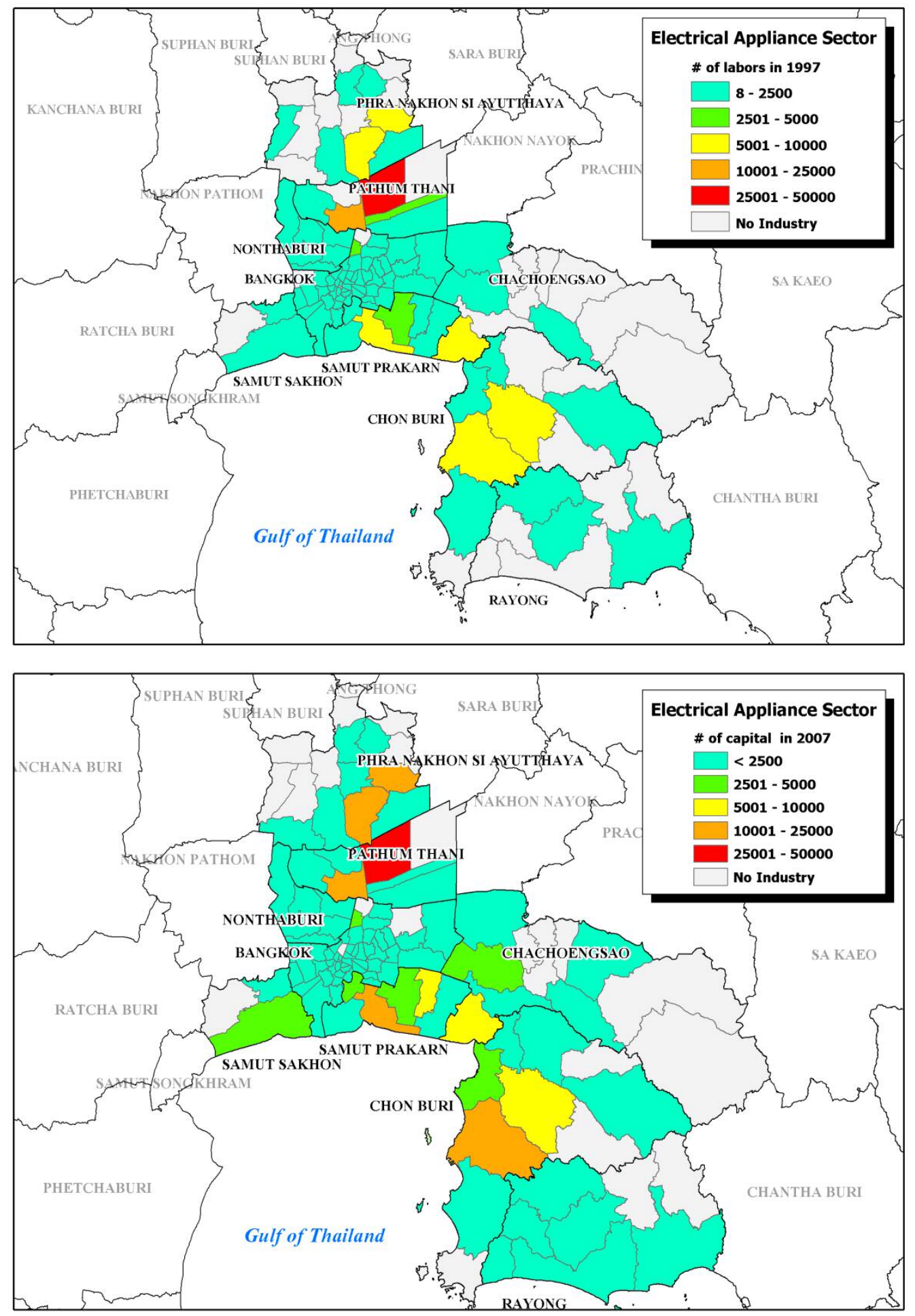
Figure 0.13: Investment in electronics
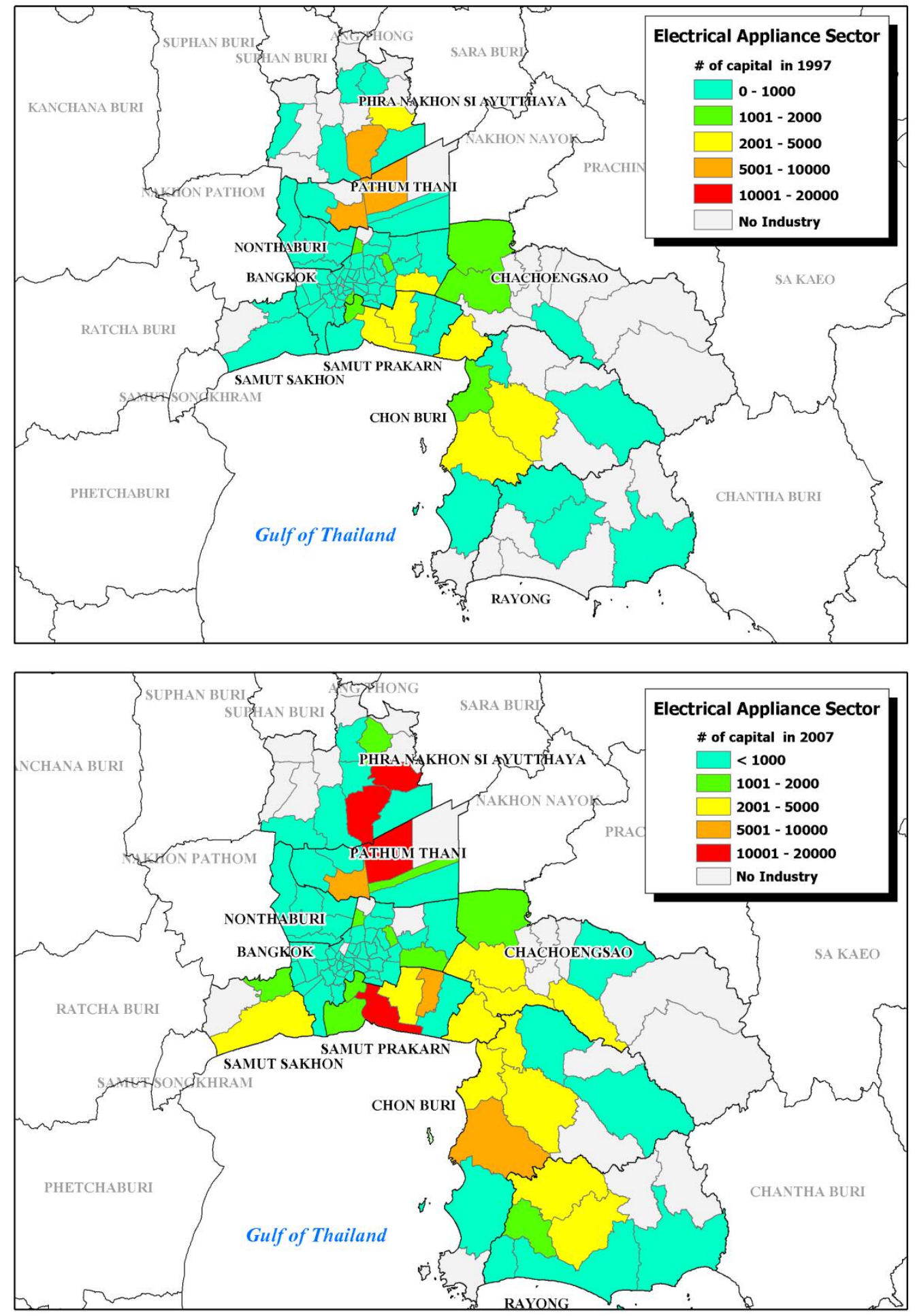
Figure 0.14: Skilled workers in electronics

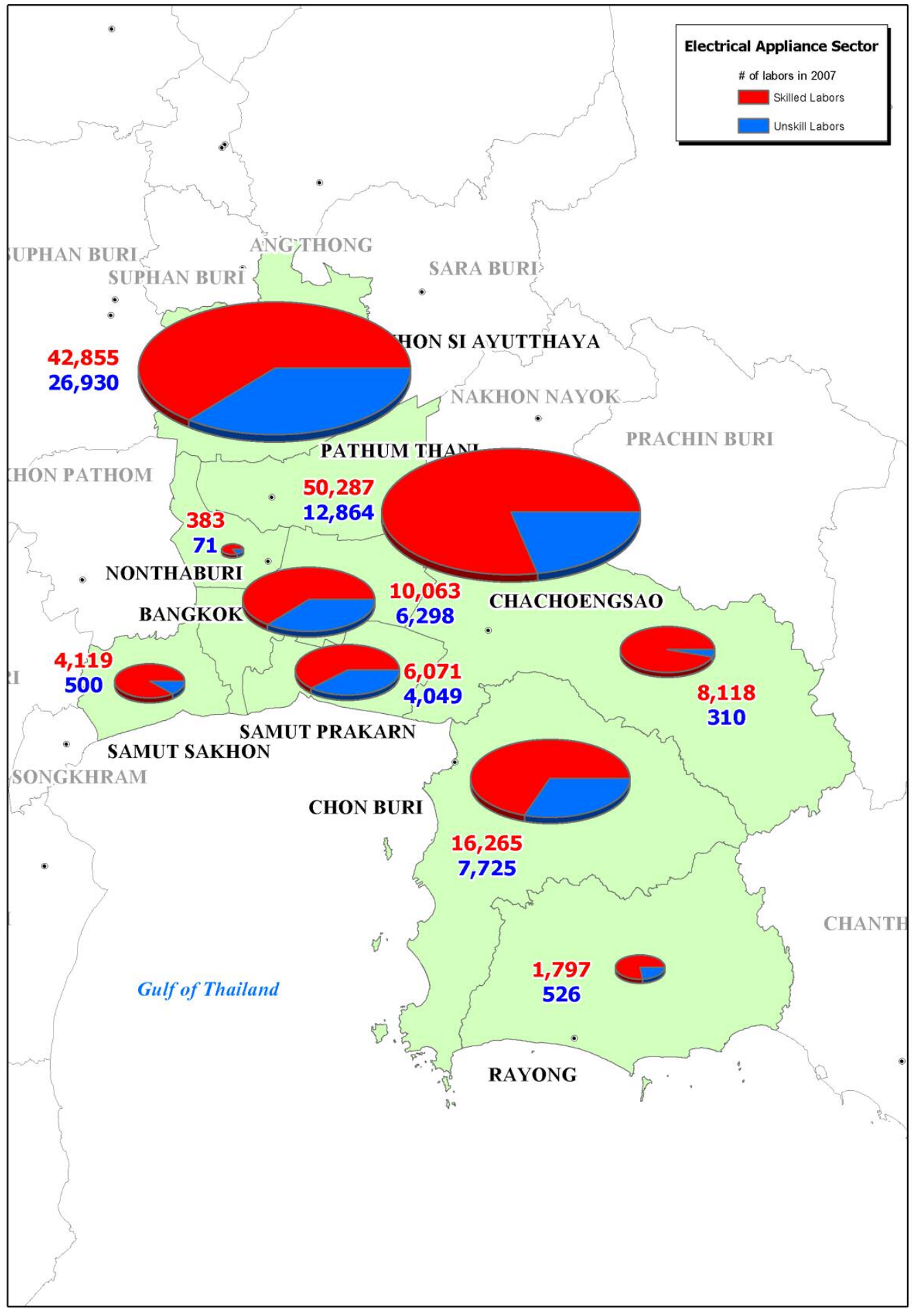




\section{Food processing industry}

Food processing, one of Thailand's most dynamic industries, is expanding rapidly in the Bangkok area. This is an industry which through the leadership of Thai firms, could become a major force in the global food industry. In 1997, food production was mainly concentrated in Bangkok (see Figure 0.15). By 2007, it had begun dispersing to the surrounding provinces, especially Muang Samut Sakhon in Samut Sakhon province (see Figure 0.16). In Bangkok alone, there were 1,538 new entrants between 1997 and 2007, double the number in Samut Sakhon (688) (see Figure 0.17). Other provinces in the vicinity also saw an increase in the number of food processing firms, although to a lesser degree. In aggregate, the number of firms engaged in food processing in the vicinity rose from 630 firms in 1997 to 2,951 firms in 2007, which apparently matched the growth in Bangkok (see

Table 0.7).

During this period, the distribution of food processing entities at the provincial level changed relatively little. The one exception is Chachoengsao, where production declined even though there was an increase in the number of establishments (see Figure 0.18). As the number of firms engaged in food processing rose, so too did employment (see Figure 0.19). Investment also increased but compared to the increase in the number of establishments and employment, the areas where investment increased substantially were small in number (see Figure 0.20). This reflects the small scale investment typical in the food processing industry.

Typically food processing firms do not employ many skilled workers. The national average share of skilled workers in food processing is $57 \%$, well below the average for auto parts and electronics. However, the share of skilled workers employed by firms in Ayutthaya, Bangkok, and Chachoengsao were $76 \%, 75 \%$, and $71 \%$ respectively (see Figure 0.21 ), suggesting that larger, modern and automated establishments were more numerous in these locations. The share of skilled workers in Chonburi was $60 \%$ and $56 \%$ in Rayong. The share of skilled workers in Samut Sakhon was exceptionally low at 34\%.

Compared to the increase in the number of establishments, the increase in employment, output, and investment is smaller in view of the scale and productivity of the food processing industry. 
Table 0.7: Changes in Food Processing Industry, 1997-2007 (values in thousand baht)

\begin{tabular}{|c|c|c|c|c|}
\hline & 1997 & 2007 & Change (\%) & $\begin{array}{c}\text { Average } \\
\text { Growth (\%) }\end{array}$ \\
\hline \multicolumn{5}{|l|}{ Bangkok } \\
\hline Number of Establishments & 398 & 1,936 & $386.4 \%$ & 15.82 \\
\hline Number of Employees & 56,690 & 81,985 & $44.6 \%$ & 3.69 \\
\hline Value of Gross Outputs & $101,267,166.4$ & $136,855,652.0$ & $35.1 \%$ & 3.01 \\
\hline Book Value of Fixed Assets & $41,372,823.4$ & $66,276,859.8$ & $60.2 \%$ & 4.71 \\
\hline \multicolumn{5}{|l|}{ Vicinity } \\
\hline Number of Establishments & 630 & 2,951 & $368.4 \%$ & 15.44 \\
\hline Number of Employees & 119,713 & 186,237 & $55.6 \%$ & 4.42 \\
\hline Value of Gross Outputs & $170,818,701.0$ & $420,992,988.1$ & $146.5 \%$ & 9.02 \\
\hline Book Value of Fixed Assets & $54,280,615.5$ & $135,924,139.8$ & $150.4 \%$ & 9.18 \\
\hline \multicolumn{5}{|l|}{ National Total } \\
\hline Number of Establishments & 3,548 & 115,696 & $3160.9 \%$ & 34.85 \\
\hline Number of Employees & 399,195 & 617,614 & $54.7 \%$ & 4.36 \\
\hline Value of Gross Outputs & $601,279,846$ & $1,128,891,097$ & $87.7 \%$ & 6.30 \\
\hline Book Value of Fixed Assets & $226,708,391.8$ & $503,207,717.6$ & $122.0 \%$ & 7.97 \\
\hline
\end{tabular}


Figure 0.15: Number of firms in food processing industry at province level
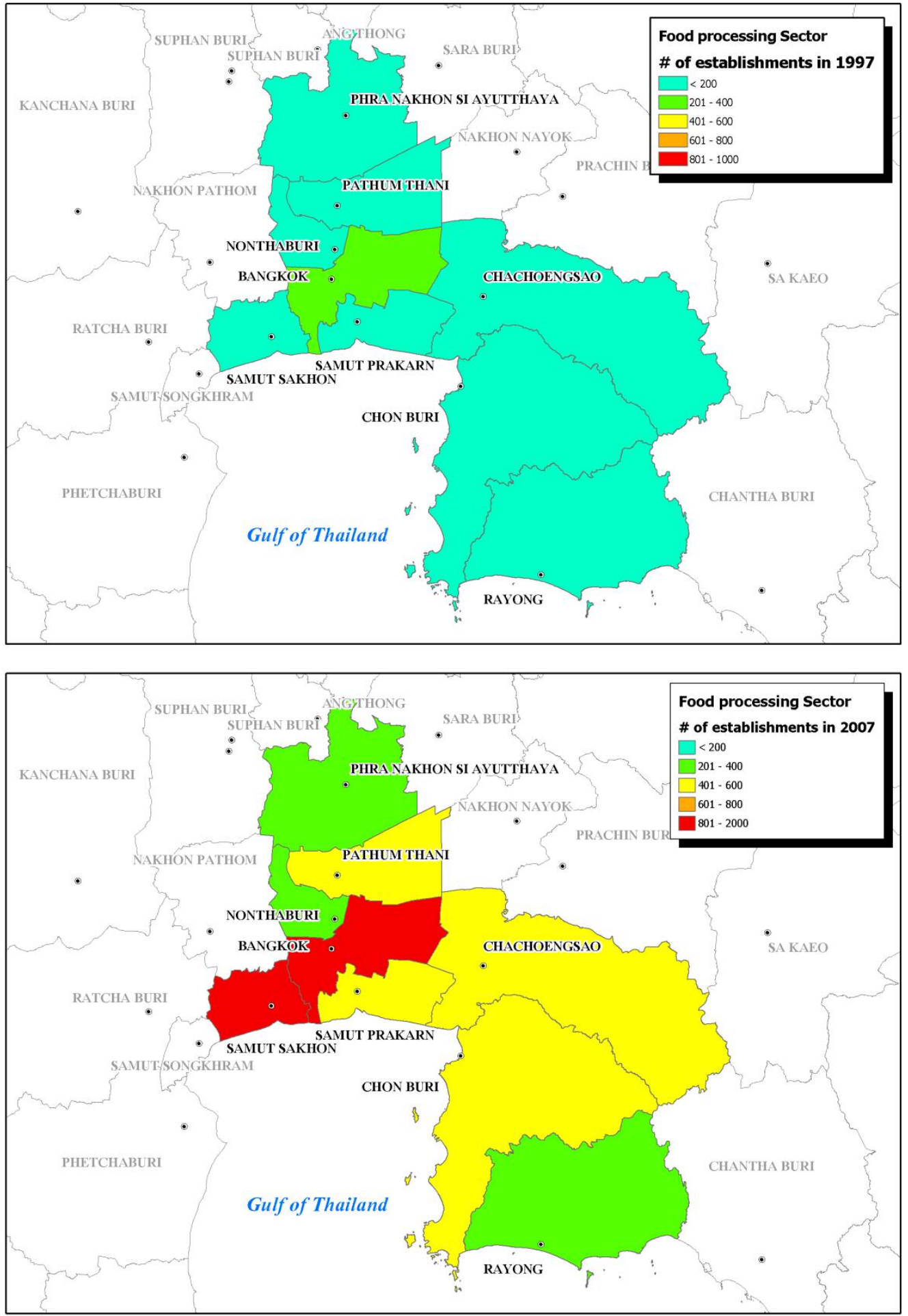
Figure 0.16: Number of firms in food processing industry at district level
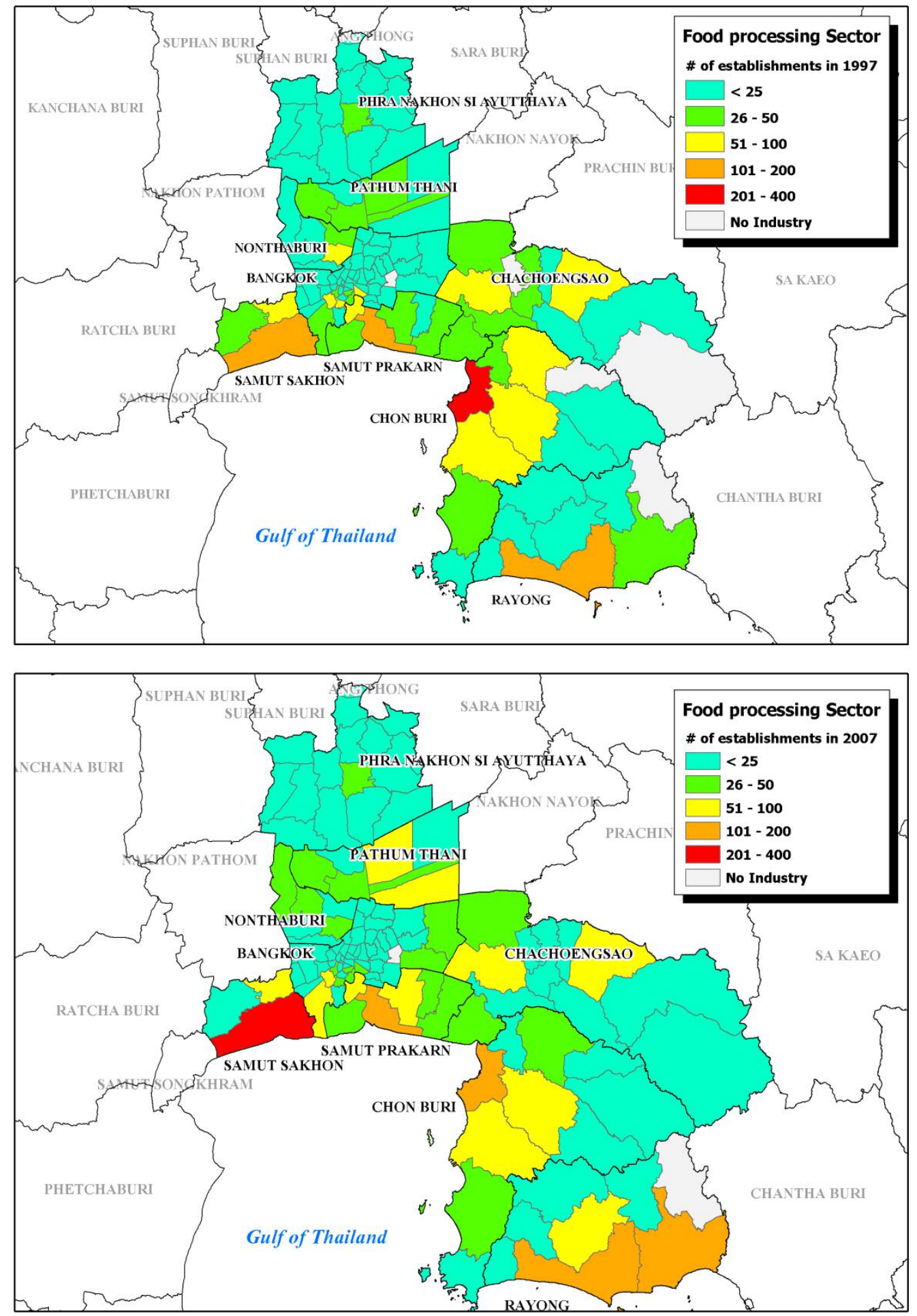
Figure 0.17: Net entry in food processing industry

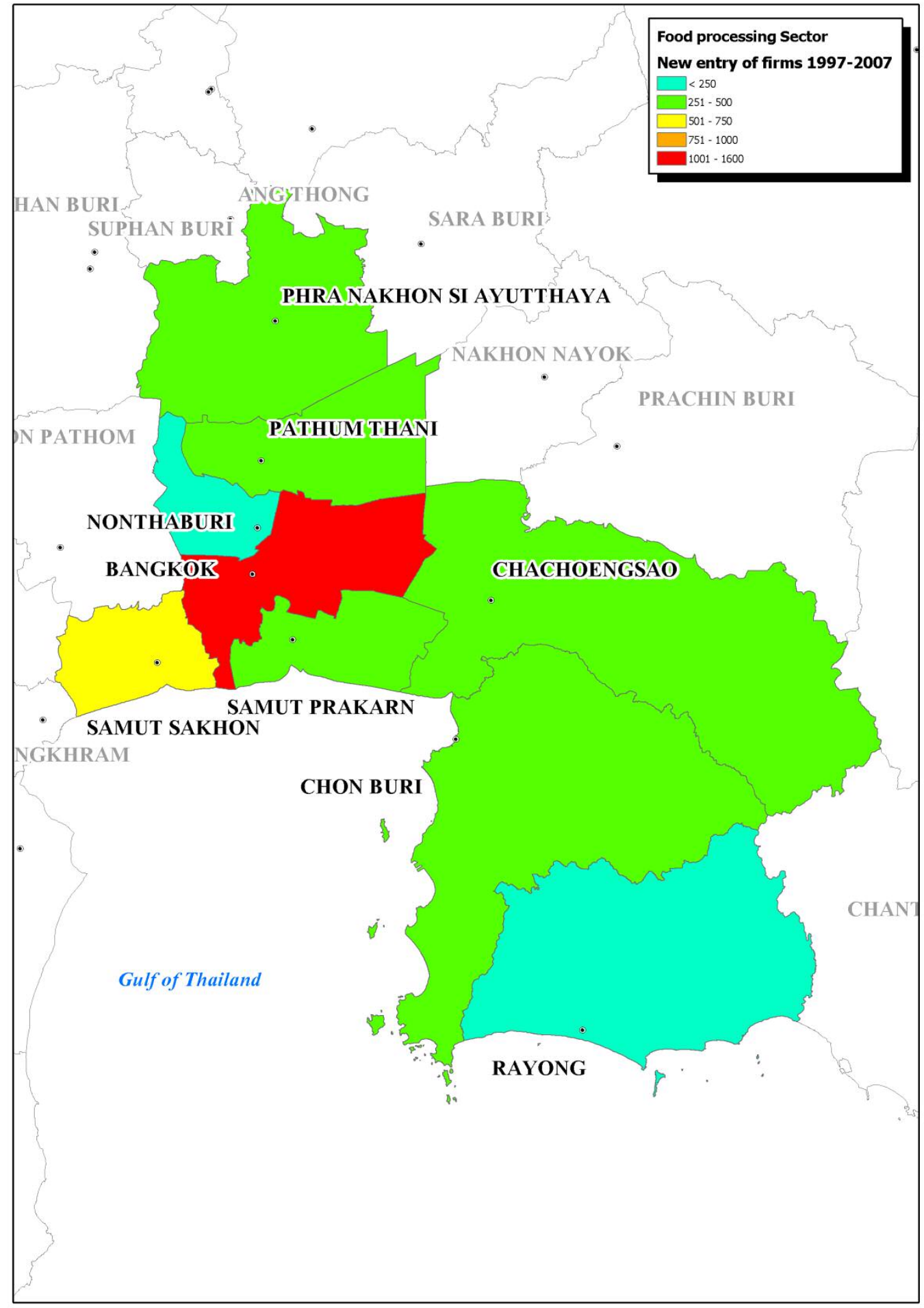


Figure 0.18: Gross outputs of food processing industry
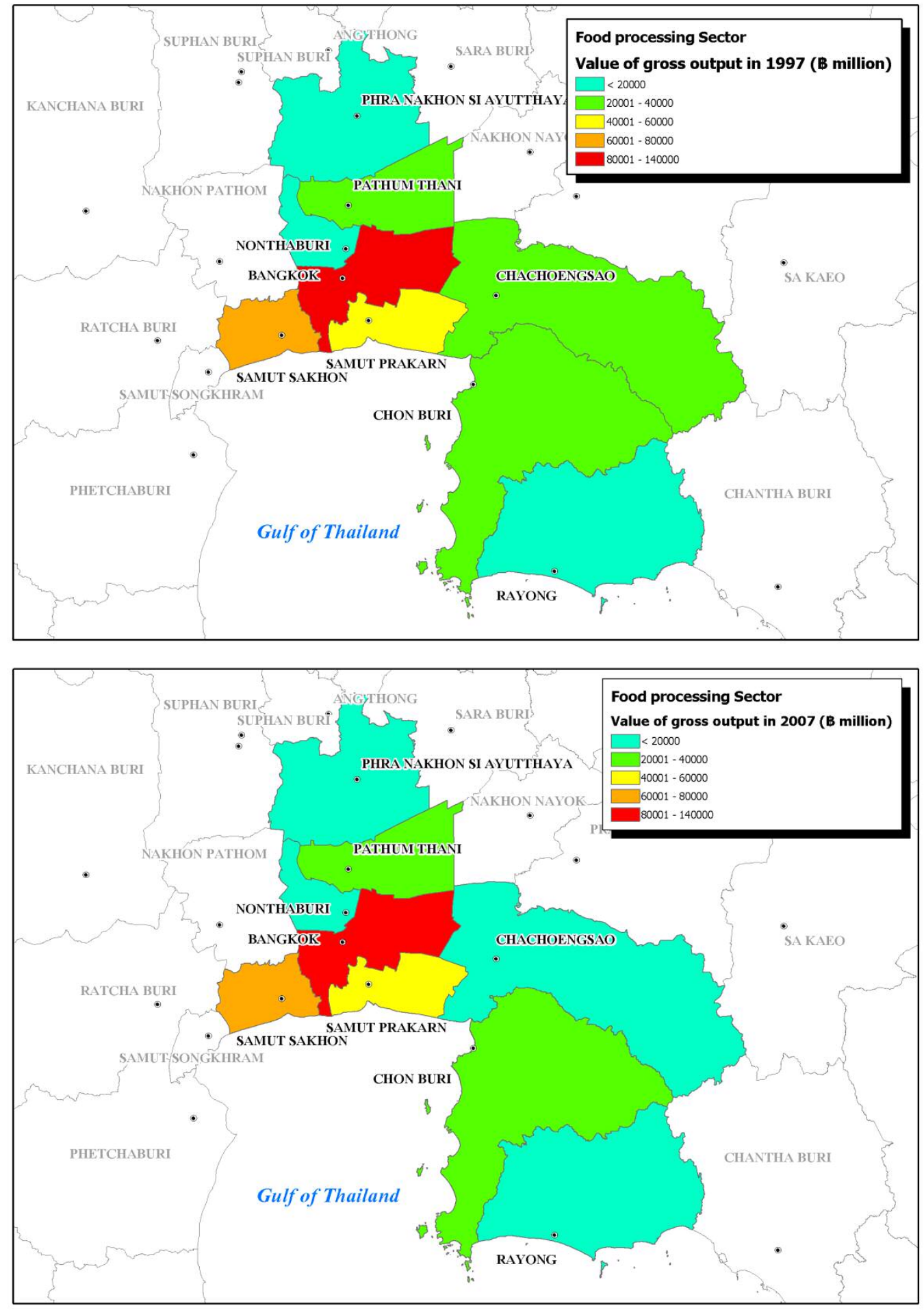
Figure 0.19: Employment in food processing industry
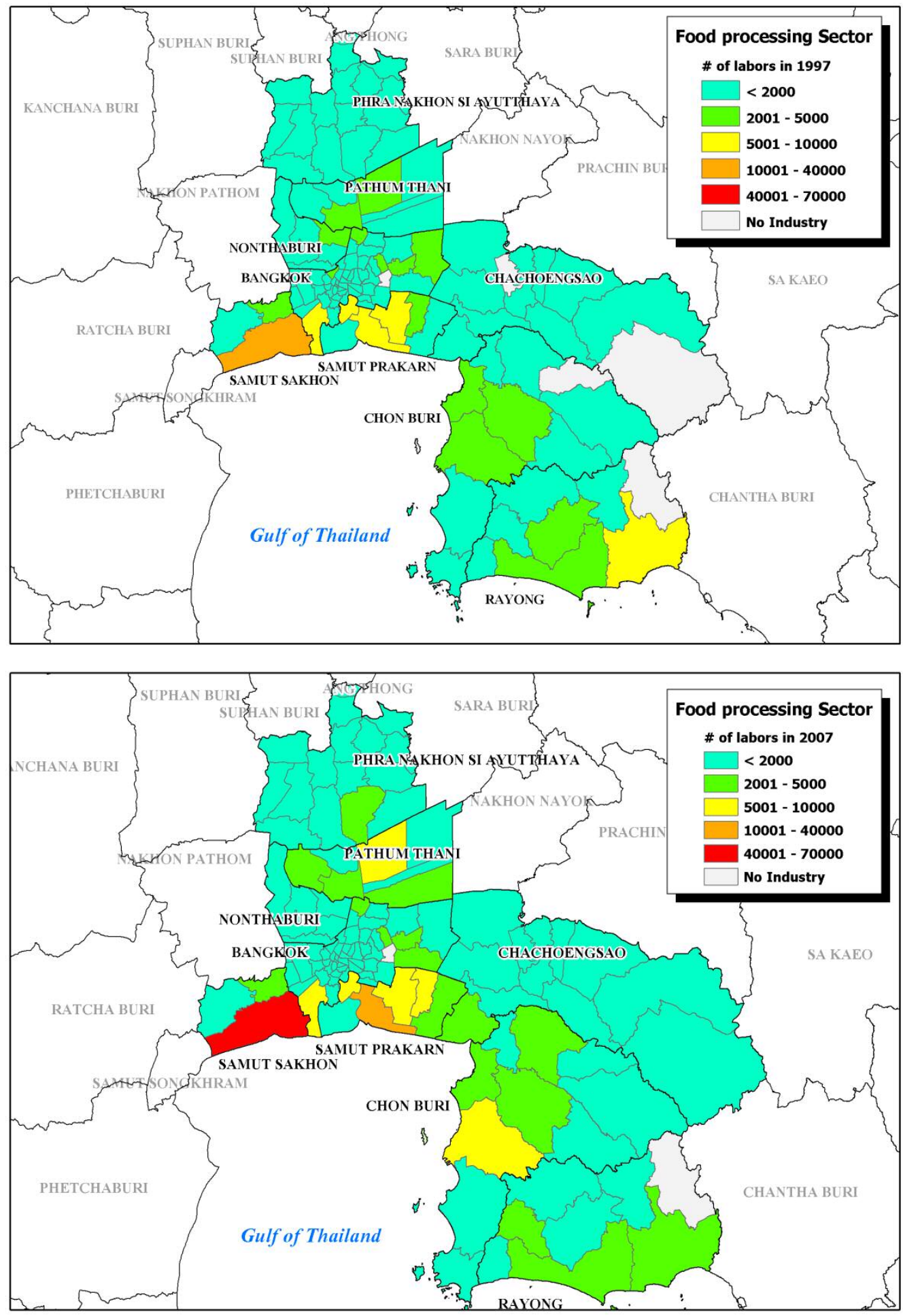
Figure 0.20: Investment in food processing industry
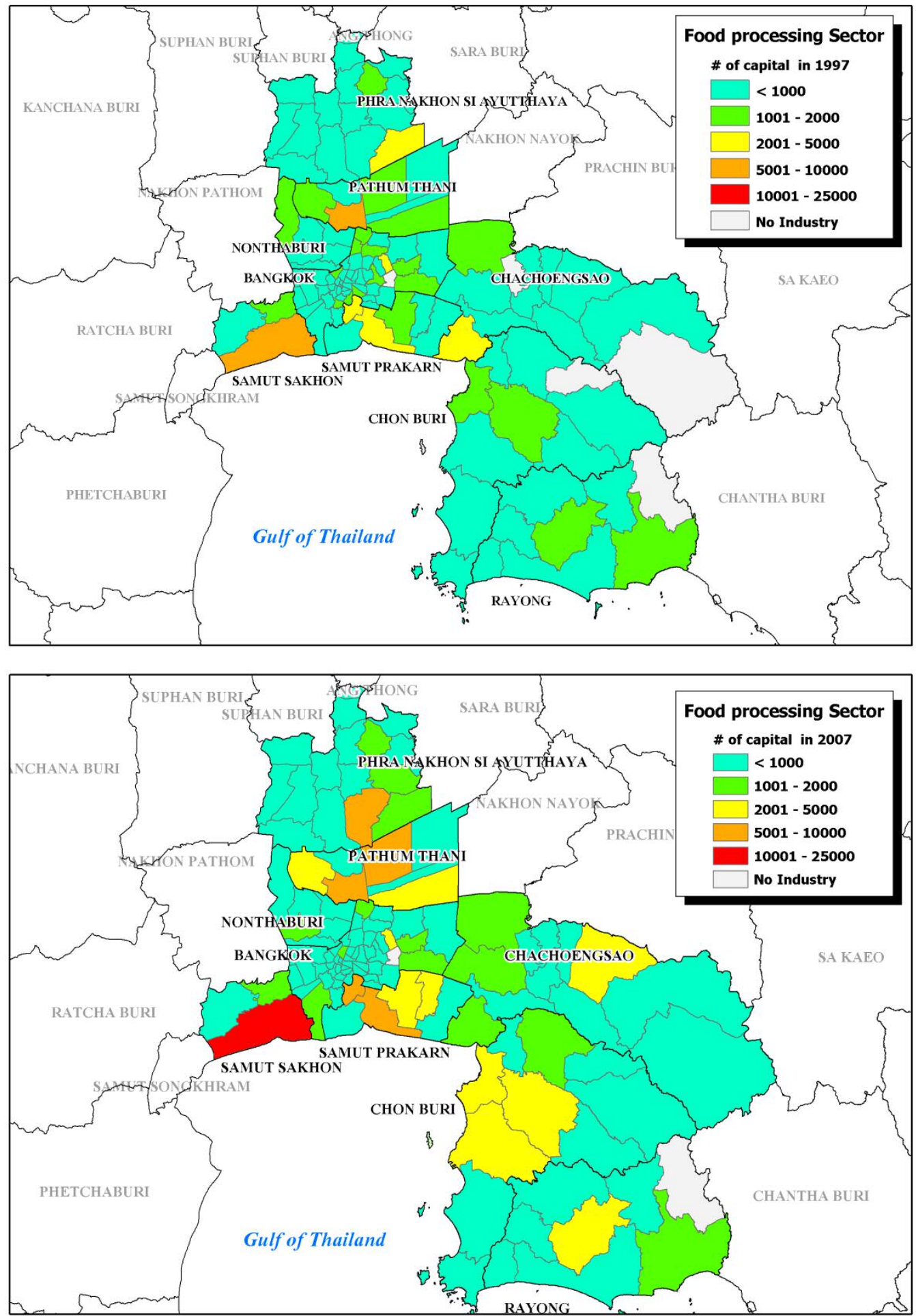
Figure 0.21: Skill composition in food processing industry

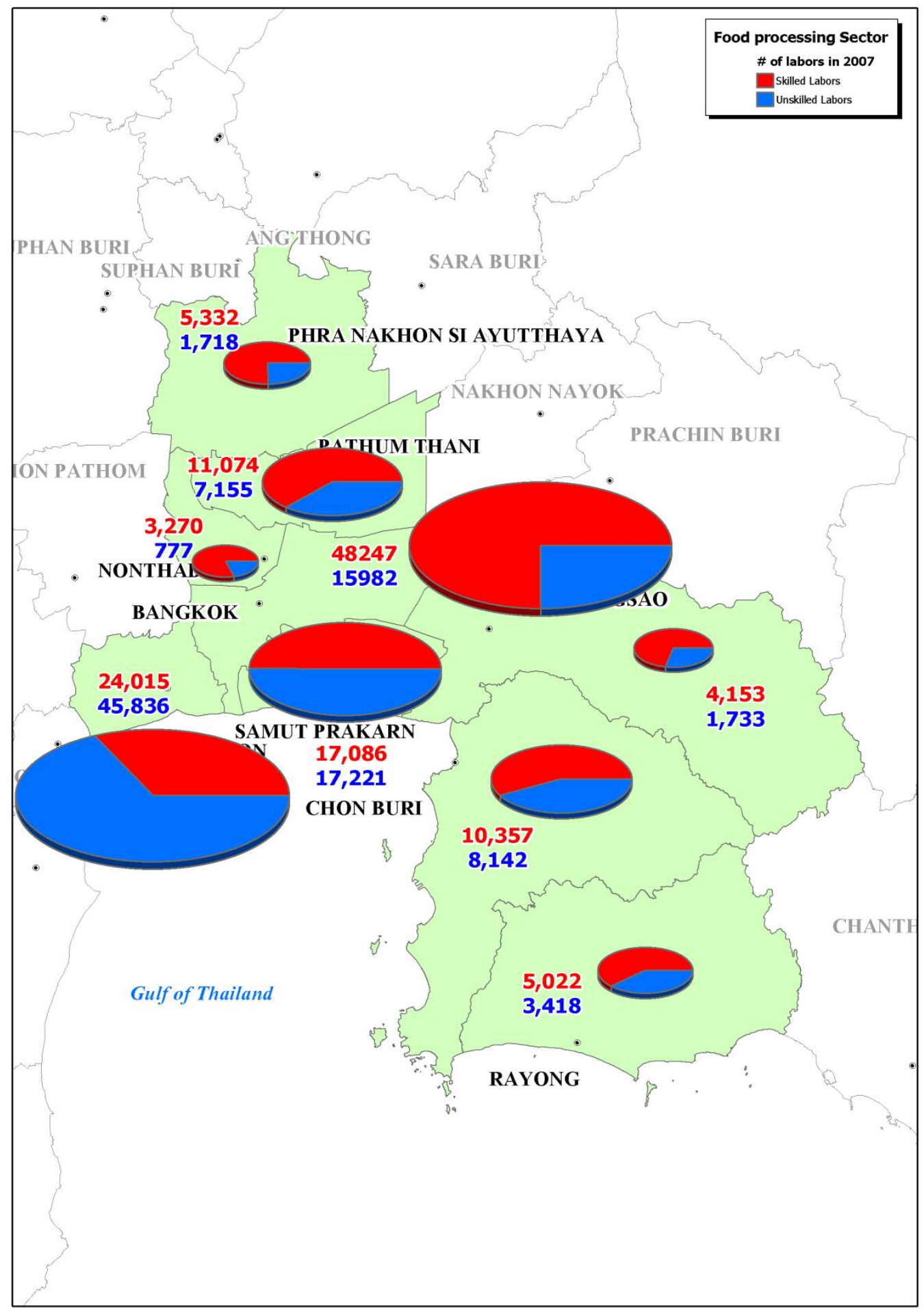




\section{Metal working}

In 1997, the metal working industry was mainly concentrated in Bangkok (see Figure 0.22). By 2007, the number of firms engaged in metal working had multiplied, mainly in the southern part of Bangkok and along the coast in Samut Sakhon and Samut Prakarn (see Figure 0.23). There were five times more firms in 2007 compared to 1997 (see Table 0.8). Bangkok remains the preferred location for metal working firms with 6,600 firms while over 5,500 operate in the vicinity (see Figure 0.24). There were 985 new firms established in Chonburi and 781 entries in Samut Sakhon. An increase in the number of establishments is also evident in Pathum Thani and Chonburi (see Figure 0.23 and Table 0.8). To some extent, the pattern of distribution of metal working mirrors that of electronic appliances which it supplies. Firms in Bangkok and the vicinity account for more than $30 \%$ of establishments, and more than two-thirds of the national output.

Gross outputs increased in the Bangkok area (see Figure 0.25) but to a lesser degree compared to the increase in the number of establishments (see Table 0.8).

Metal working industry is moderately skill intensive, with the share of skilled workers being $70 \%$ nationally. However, the shares of skilled workers approach that of the national average only in Ayutthaya, Chachoengsao, and Bangkok (see Figure 0.28). The shares of skilled workers in other provinces are much lower than the national average. This may be one reason why employment and investment have increased in these provinces yet the output has not changed as much. 
Table 0.8: Changes in Metal Industry, 1997-2007 (values in thousand baht)

\begin{tabular}{lrrrr} 
& 1997 & 2007 & Change (\%) & $\begin{array}{r}\text { Average } \\
\text { Growth } \\
\text { Rates (\%) }\end{array}$ \\
\hline Bangkok & & & & \\
Number of Establishments & 1,030 & 6,598 & $540.6 \%$ & $20.4 \%$ \\
Number of Employees & 38,010 & 56,836 & $49.5 \%$ & $4.1 \%$ \\
Value of Gross Outputs & $28,723,368.2$ & $57,016,770.6$ & $98.5 \%$ & $7.1 \%$ \\
Book Value of Fixed Assets & $13,264,307.3$ & $26,526,097.1$ & $100.0 \%$ & $7.2 \%$ \\
& & & & \\
Vicinity & & & & \\
Number of Establishments & 53,667 & 103,626 & $93.1 \%$ & $6.8 \%$ \\
Number of Employees & $62,159,178.7$ & $166,180,464.7$ & $167.3 \%$ & $10.3 \%$ \\
Value of Gross Outputs & $31,240,230.4$ & $66,102,274.9$ & $111.6 \%$ & $7.8 \%$ \\
Book Value of Fixed Assets & & & & \\
& & & & \\
National Total & 2,261 & 34,308 & $1417.4 \%$ & $31.3 \%$ \\
Number of Establishments & 129,347 & 252,568 & $95.3 \%$ & $6.9 \%$ \\
Number of Employees & $159,319,217.3$ & $366,765,342.3$ & $130.2 \%$ & $8.7 \%$ \\
Value of Gross Outputs & $103,764,271.9$ & $155,333,400.8$ & $49.7 \%$ & $4.1 \%$ \\
Book Value of Fixed Assets & & & & \\
\hline
\end{tabular}


Figure 0.22: Number of establishments in metal working industry at province level
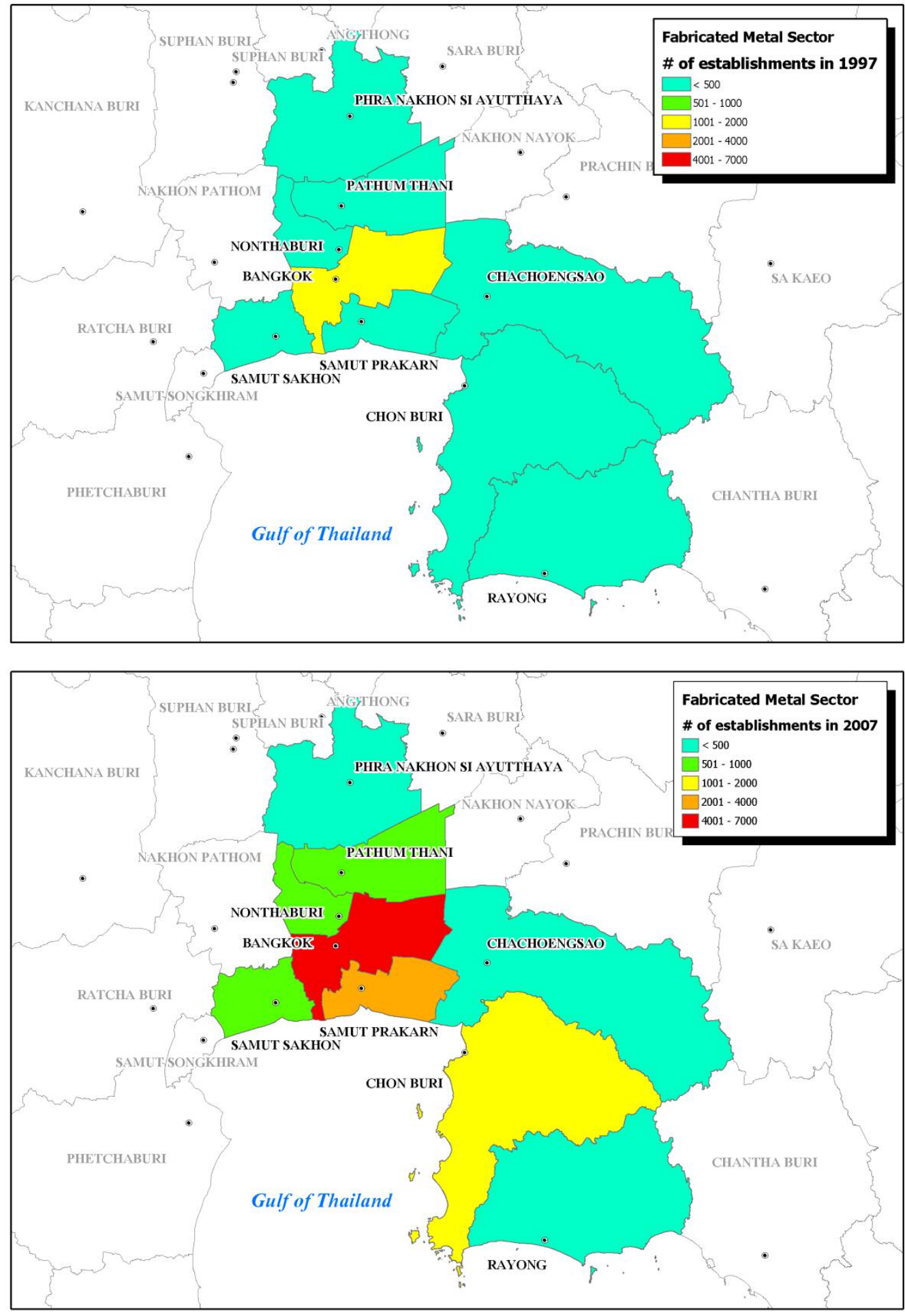
Figure 0.23: Number of establishments in metal working industry at district level
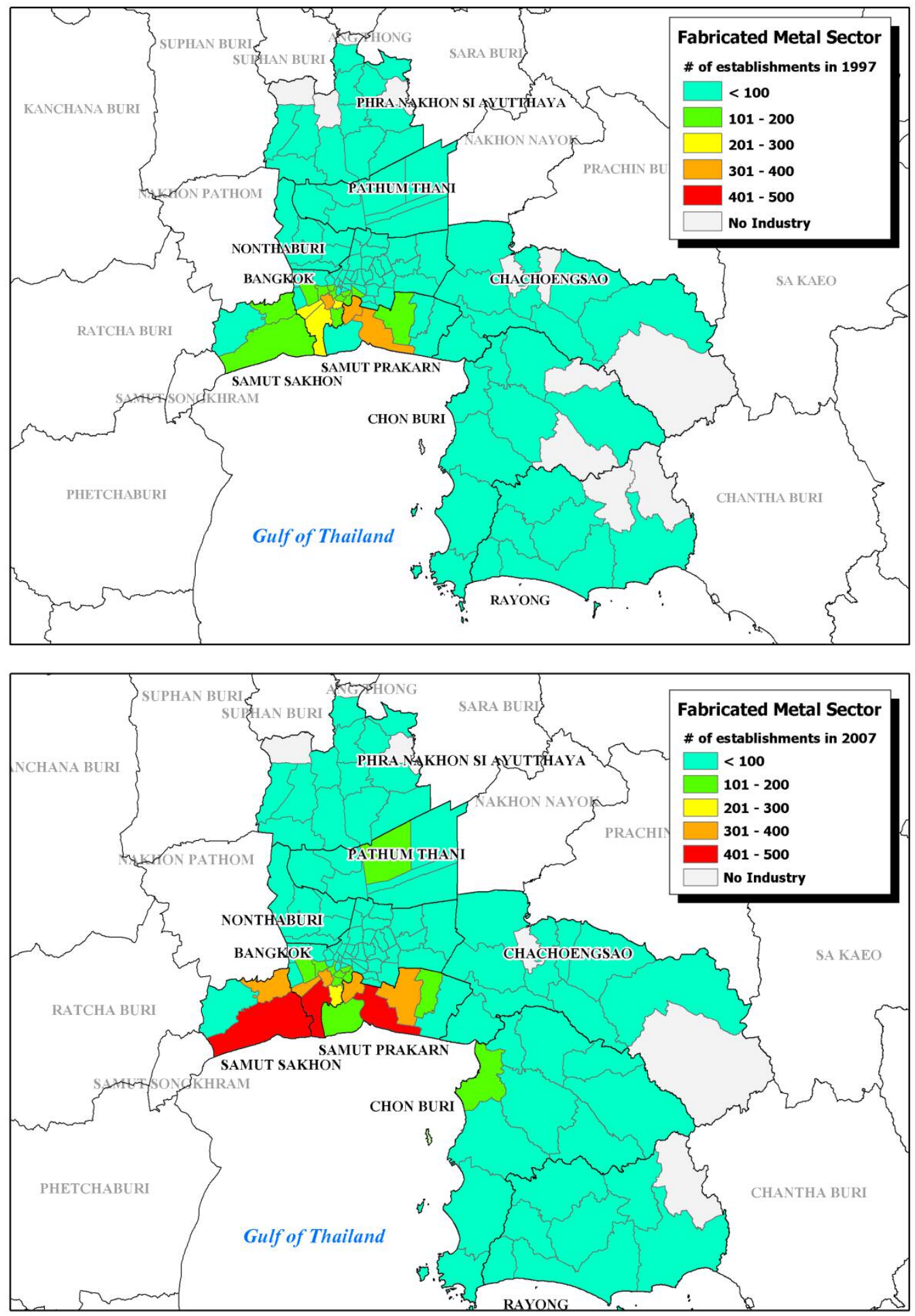
Figure 0.24: New entry in metal working industry

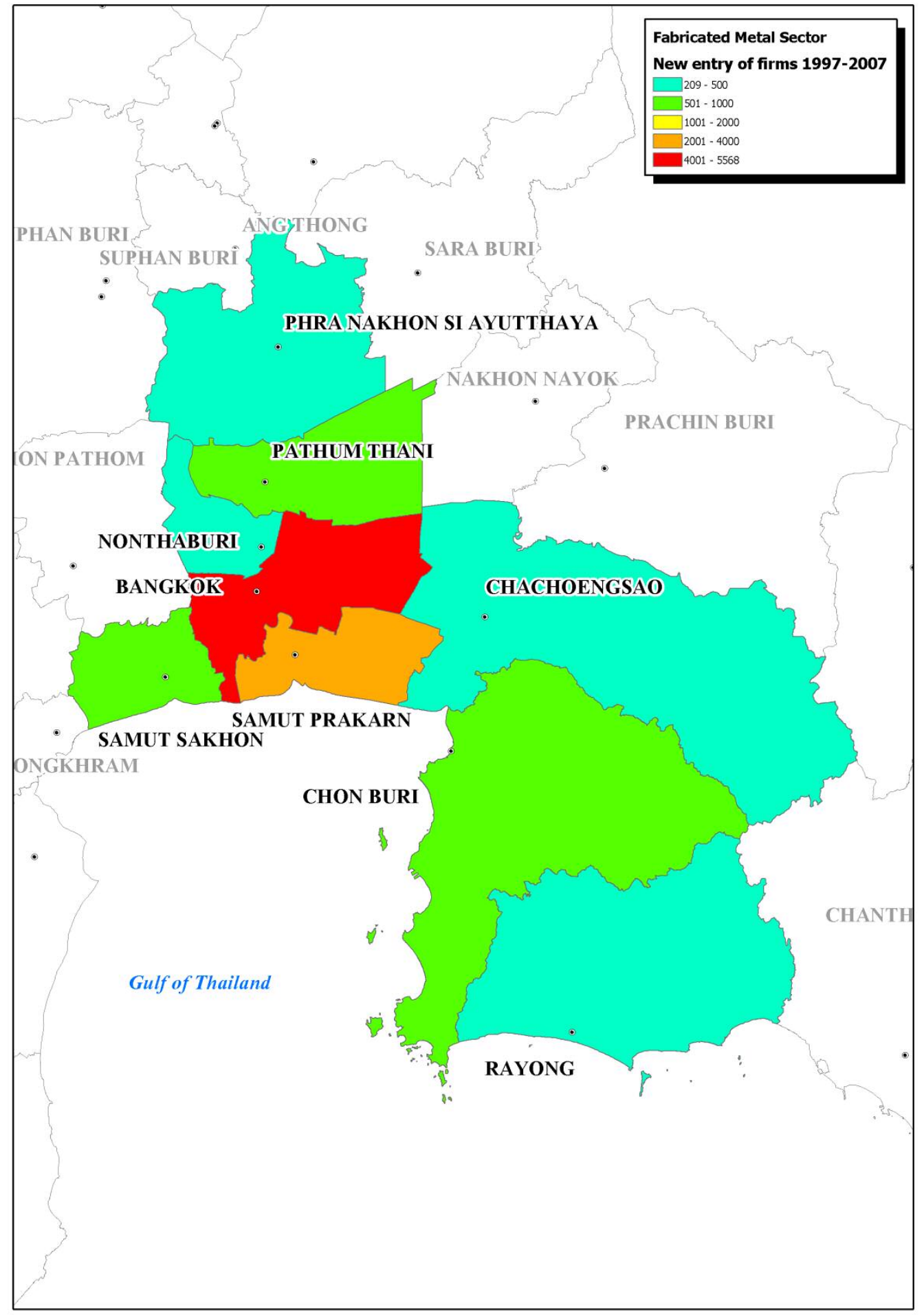


Figure 0.25: Gross outputs of metal working industry
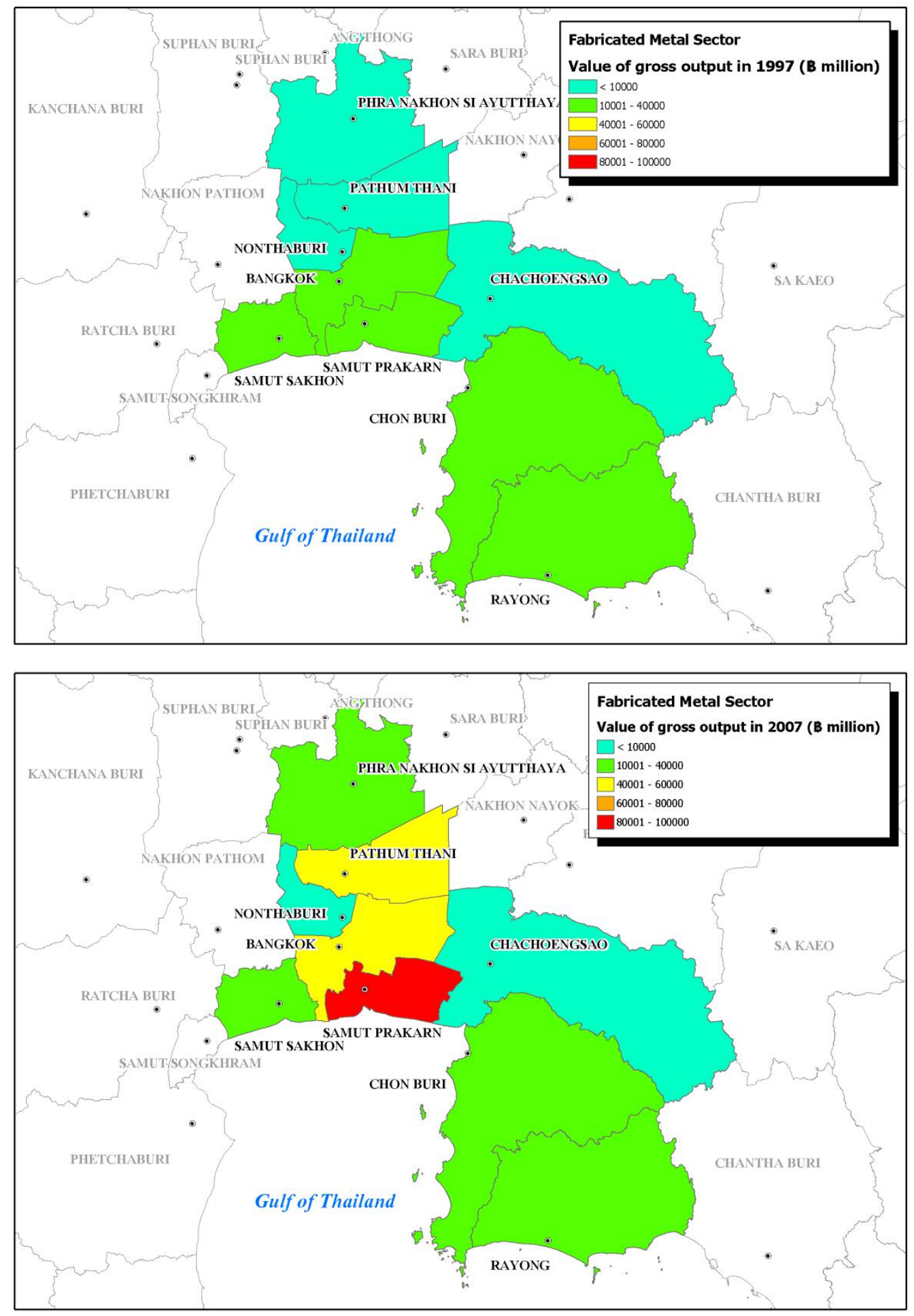
Figure 0.26: Employment in metal working industry
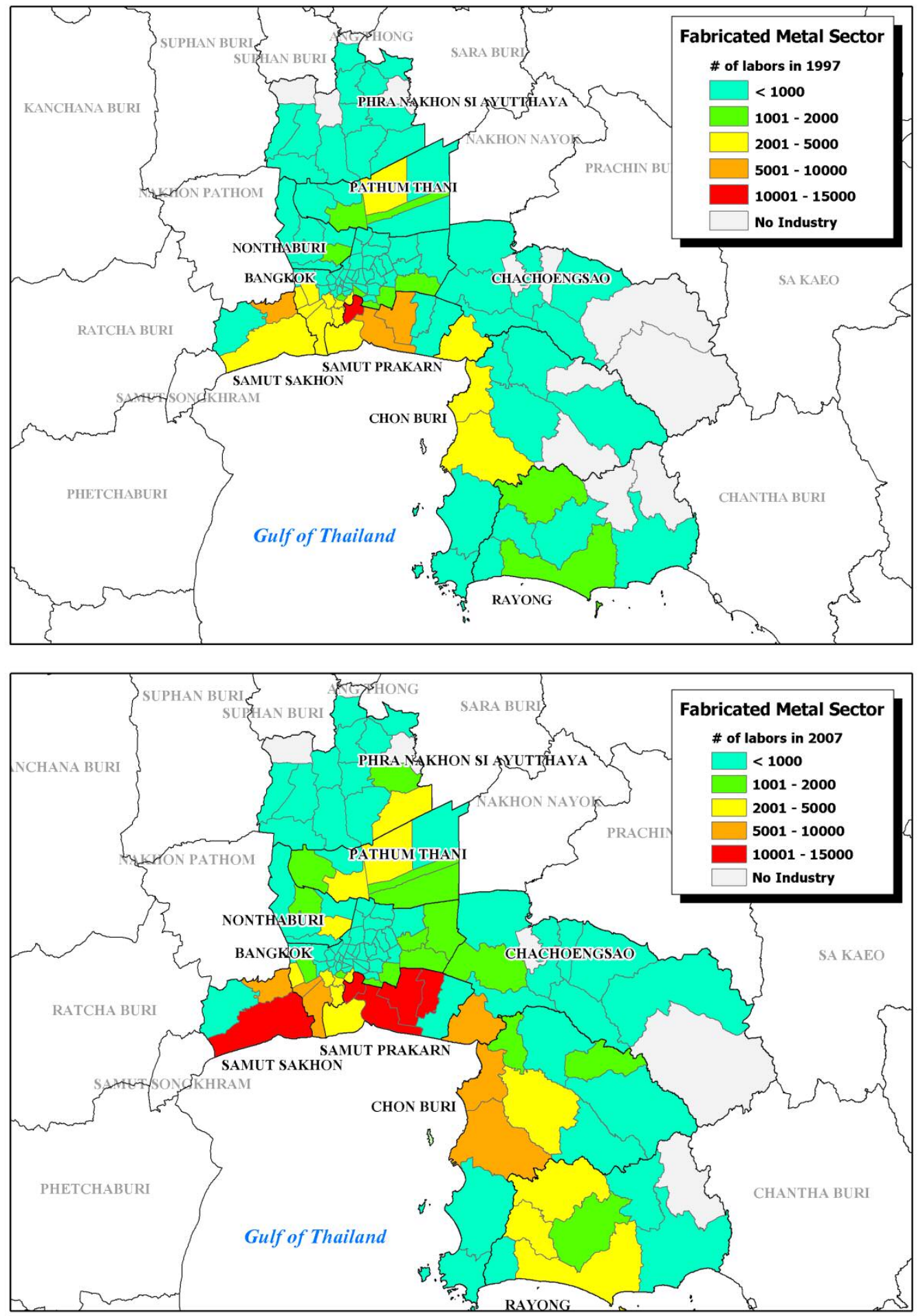
Figure 0.27: Investment in metal working industry
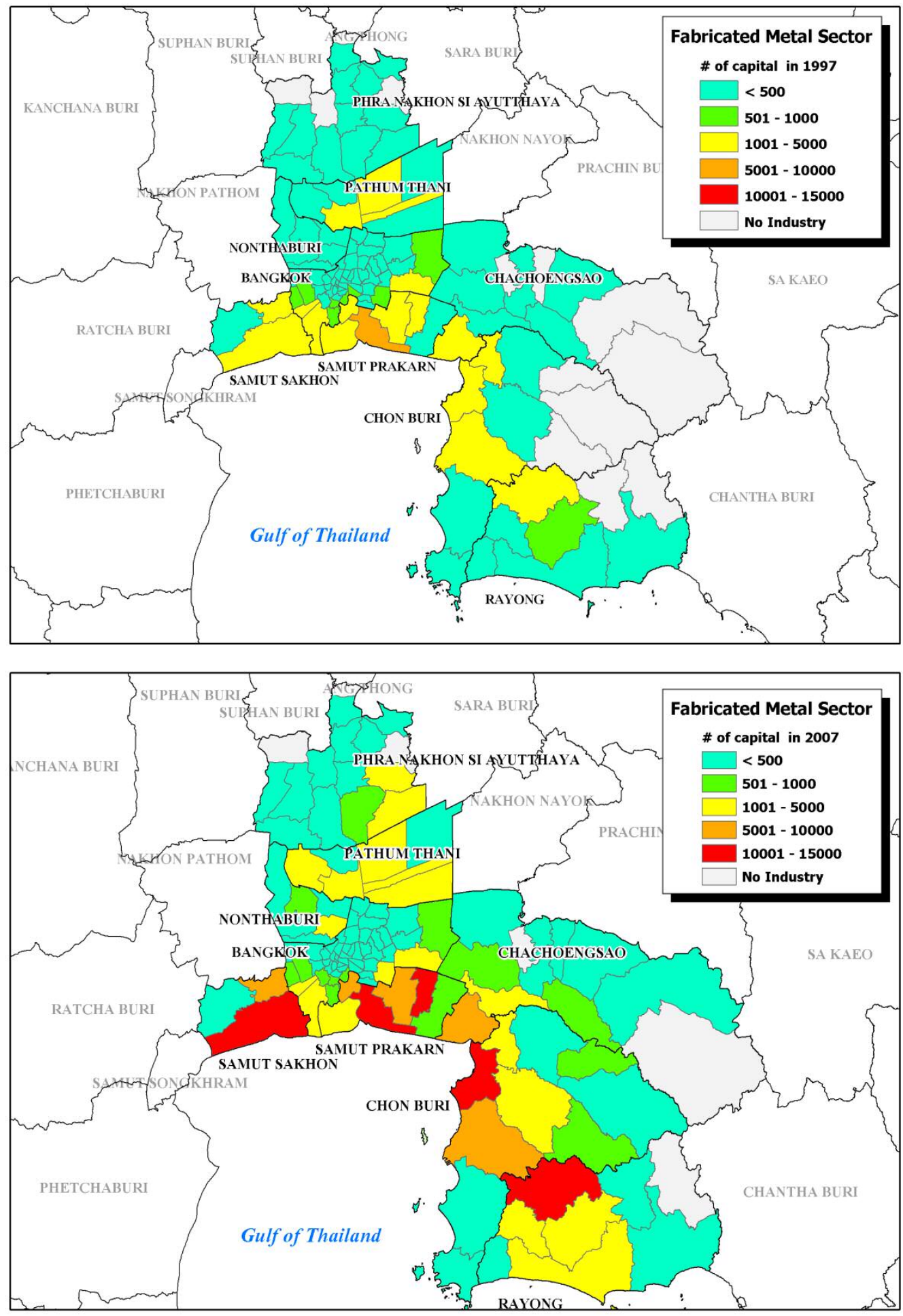
Figure 0.28: Share of skilled worker in metal working industry

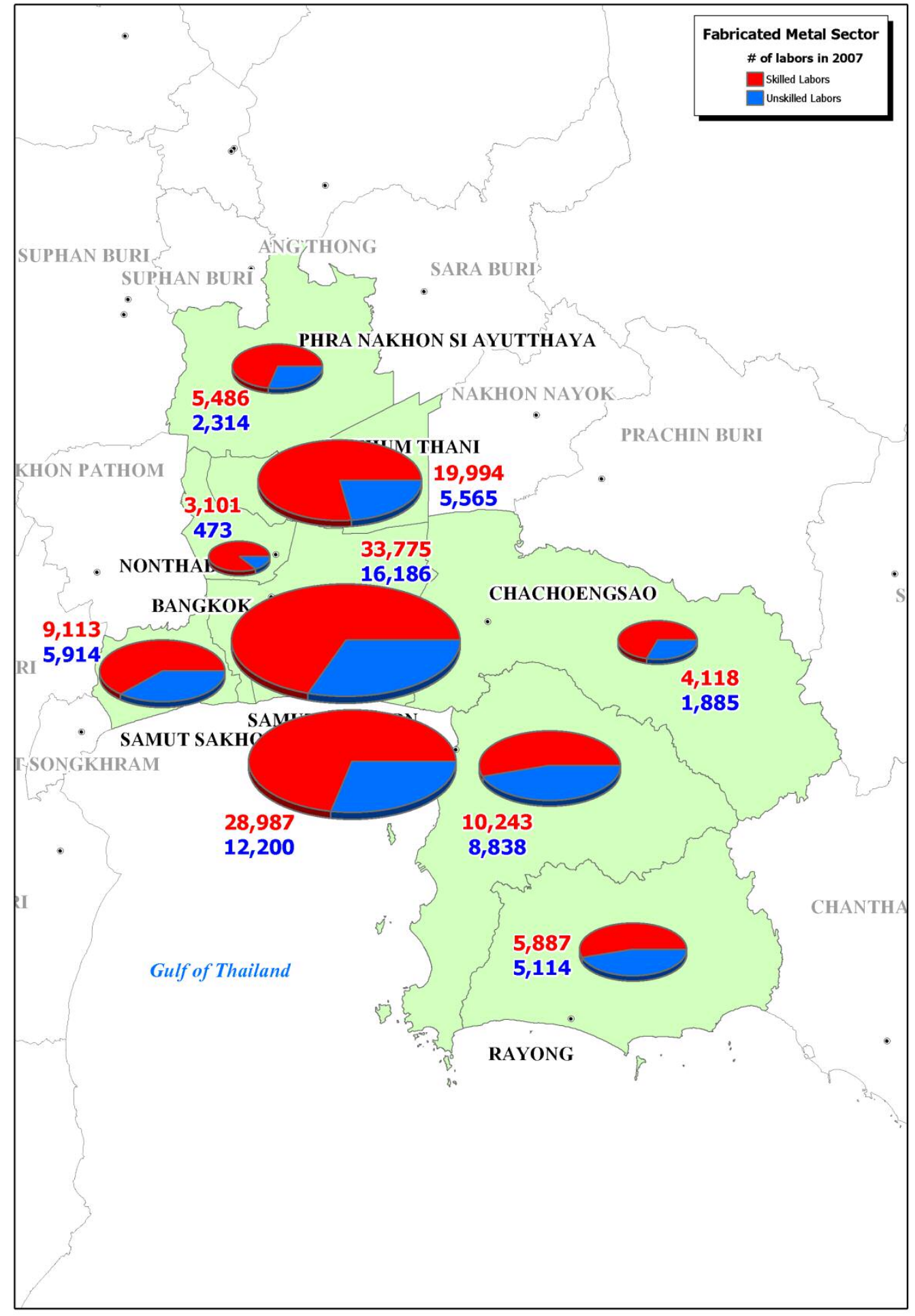




\section{Garments and textile industry}

Thailand's garment and textile industry has its roots in Bangkok and much like other industries it has spread to parts of the vicinity notably in Samut Sakhon (see Figure 0.29). Together with Bangkok, the coastal areas of Samut Sakhon and Samut Prakarn (see Figure 0.30) are becoming centers of garment and textile industries. Establishments are also proliferating in Nonthaburi, Pathum Thani, Ayutthaya, and Chonburi. More than 13,000 new firms were added to this industry between 1997 and 2007 in Bangkok alone (see Figure 0.31). The number of production units in Chonburi and Ayutthaya grew by 1,186 and 1,106 respectively.

The gross output and employment of the textile industry increased in Bangkok, Samut Sakhon and Samut Prakarn (see Figure 0.32 and Figure 0.33). But overall, the increase in employment in the vicinity was small relative to the increase in output suggesting that the industry was moving into higher value products. Investment also did not show any systematic increase (see Figure 0.34). The exception was Samut Sakhon where number of establishments, employment, and investment all increased.

The national average share of skilled workers in the garment and textile industry is $60 \%$. Among these provinces, the share of skilled workers is highest in Chonburi (84\%) followed by Rayong (78\%), Ayutthaya (77\%) and Bangkok (74\%) (see Figure 0.35). The share of skilled workers is lowest in Chachoengsao with only $21 \%$ of workers considered to be skilled. 
Table 0.9: Changes in Textiles Industry, 1997-2007 (values in thousand baht)

\begin{tabular}{lrrrr} 
& 1997 & 2007 & Change (\%) & $\begin{array}{r}\text { Average } \\
\text { Growth } \\
\text { Rates (\%) }\end{array}$ \\
\hline Bangkok & & & \\
Number of Establishments & 1,915 & 15,883 & $729.4 \%$ & $23.6 \%$ \\
Number of Employees & 141,699 & 188,371 & $32.9 \%$ & $2.9 \%$ \\
Value of Gross Outputs & $74,166,393$ & $147,933,665$ & $99.5 \%$ & $7.1 \%$ \\
Book Value of Fixed Assets & $27,584,676$ & $70,887,158$ & $157.0 \%$ & $9.9 \%$ \\
& & & & \\
Vicinity & & & & \\
Number of Establishments & 166,038 & 204,008 & $22.9 \%$ & $2.1 \%$ \\
Number of Employees & $119,288,943$ & $211,820,037$ & $77.6 \%$ & $5.9 \%$ \\
Value of Gross Outputs & $94,739,285$ & $93,205,527$ & $-1.6 \%$ & $-0.2 \%$ \\
Book Value of Fixed Assets & & & & \\
& & & & \\
National Total & 3,397 & 165,074 & $4759.4 \%$ & $47.5 \%$ \\
Number of Establishments & 400,011 & 657,389 & $64.3 \%$ & $5.1 \%$ \\
Number of Employees & $263,283,139$ & $482,613,390$ & $83.3 \%$ & $6.2 \%$ \\
Value of Gross Outputs & $176,674,701$ & $278,079,378$ & $57.4 \%$ & $4.6 \%$ \\
Book Value of Fixed Assets & & & & \\
\hline
\end{tabular}


Figure 0.29: Number of establishments in textile industry at province level
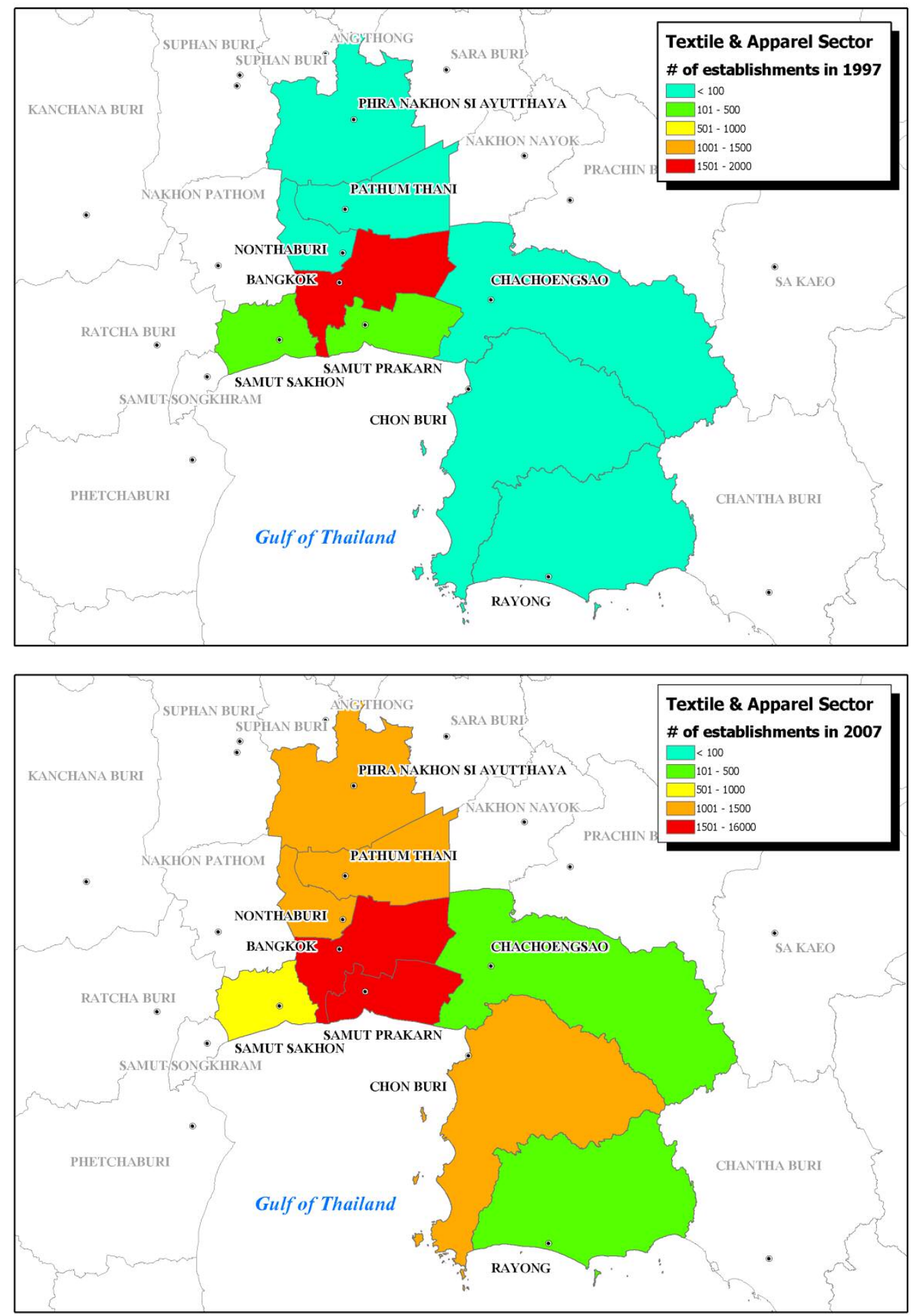
Figure 0.30: Number of establishments in textile industry at district level
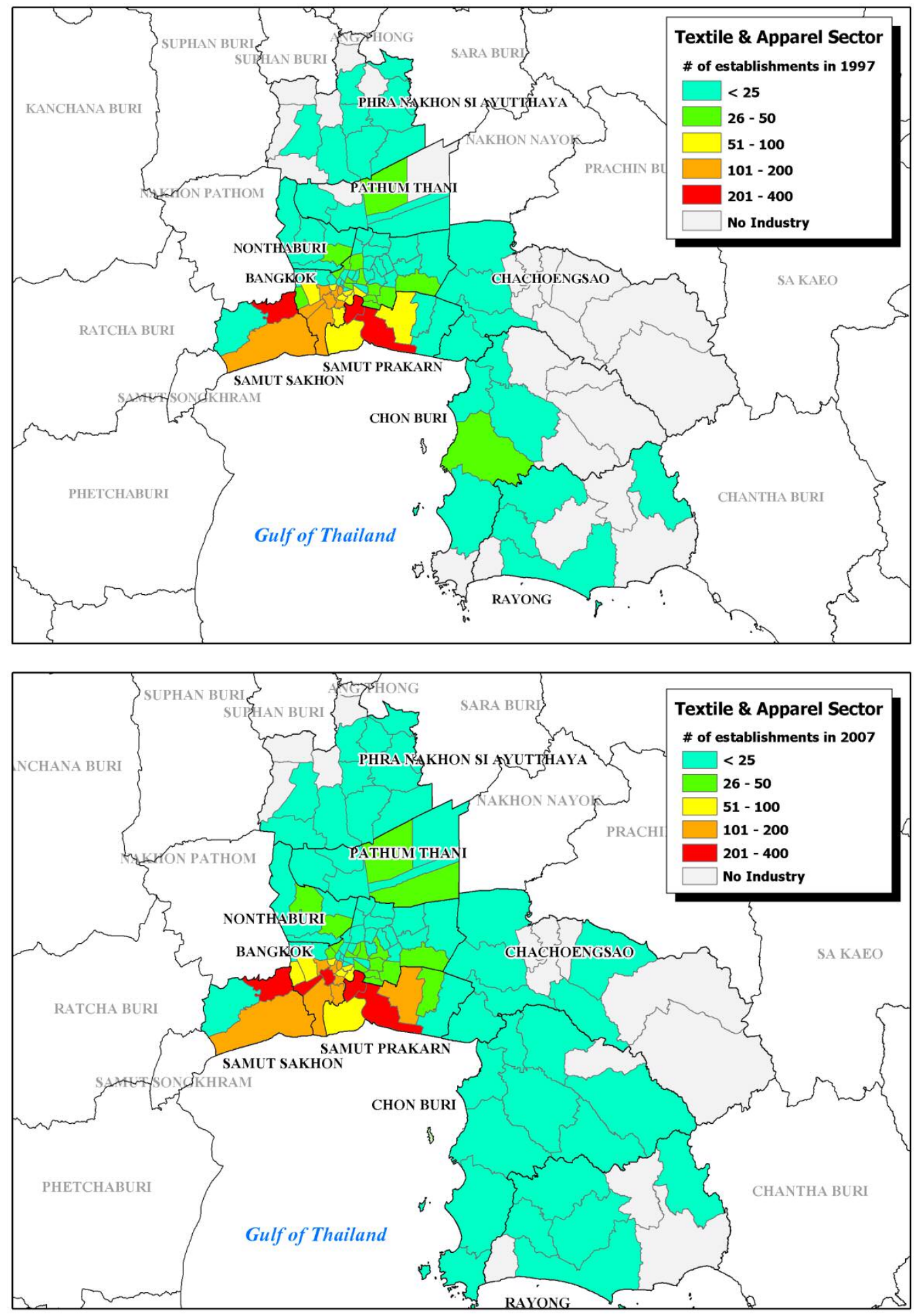
Figure 0.31: New entries in textile industry

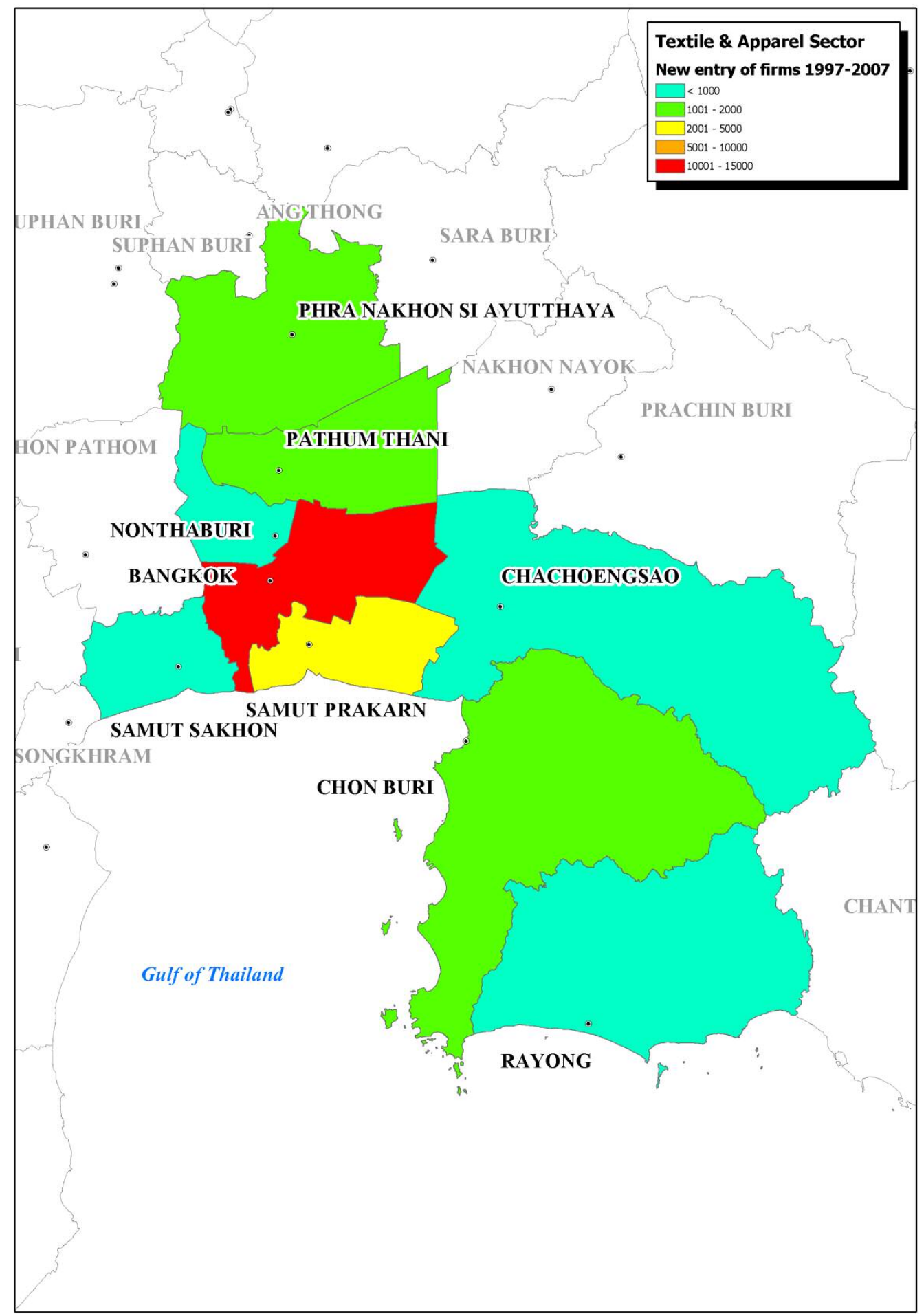


Figure 0.32: Gross outputs of textile industry
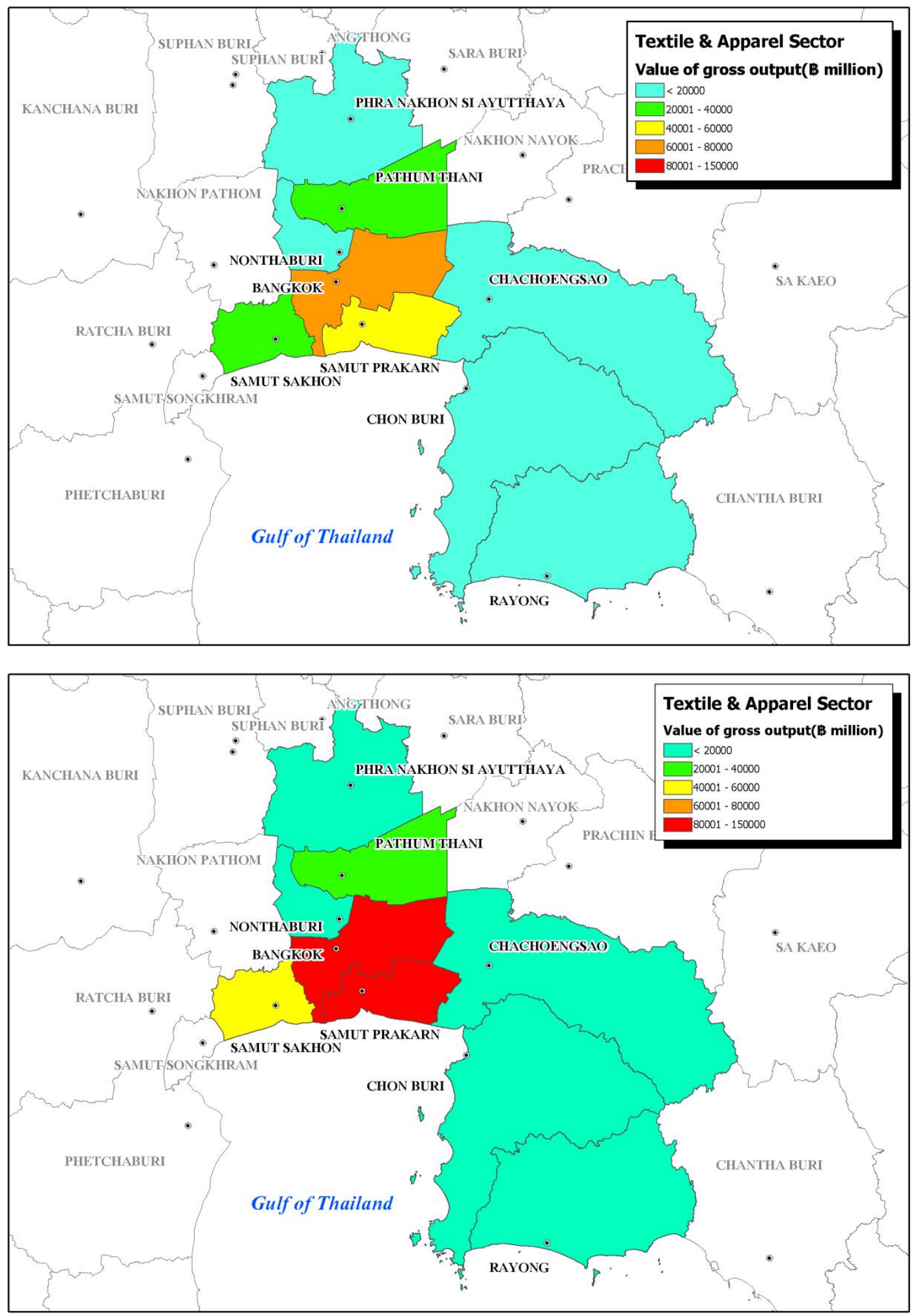
Figure 0.33: Employment in textile industry
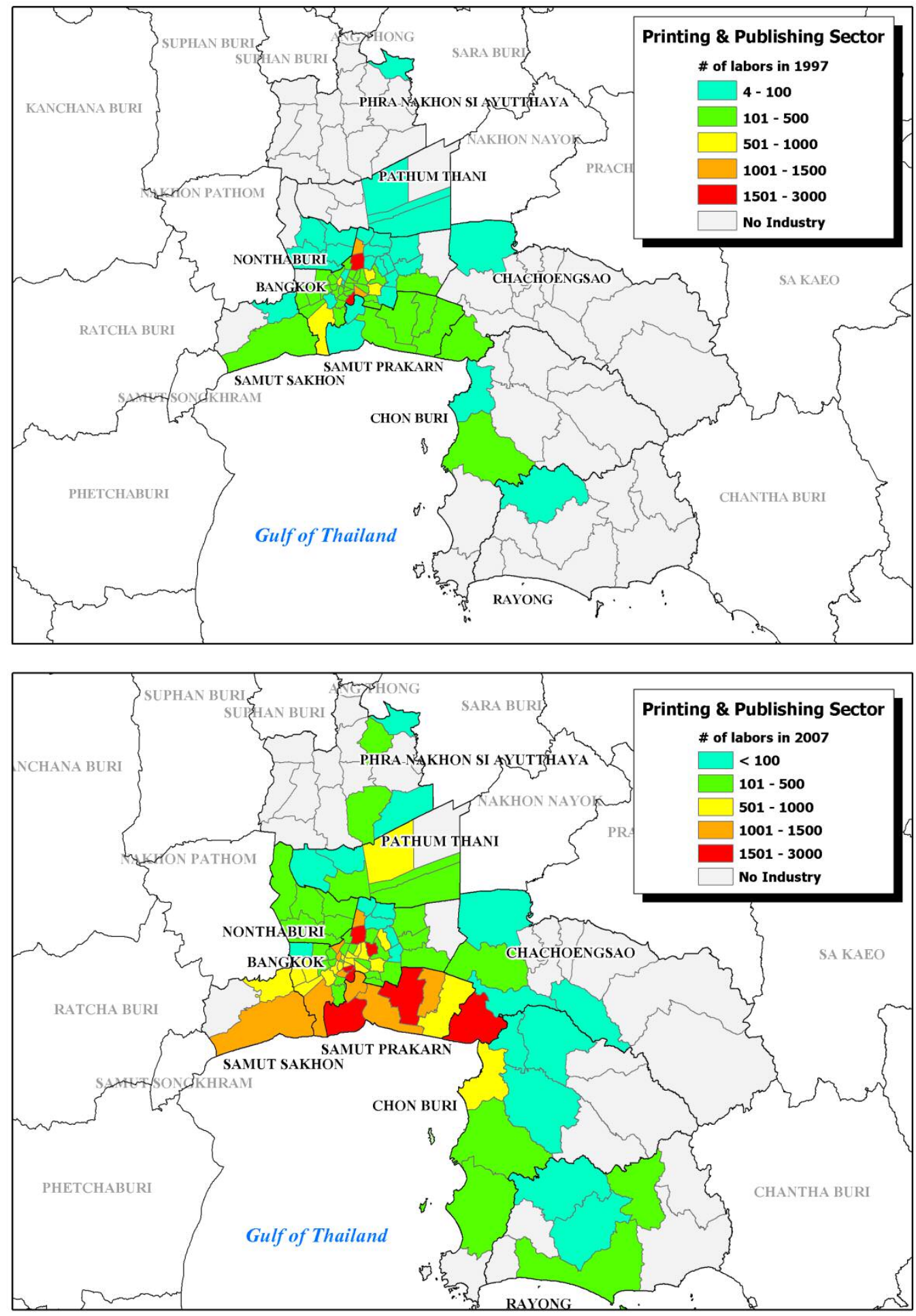
Figure 0.34: Investment in textile industry
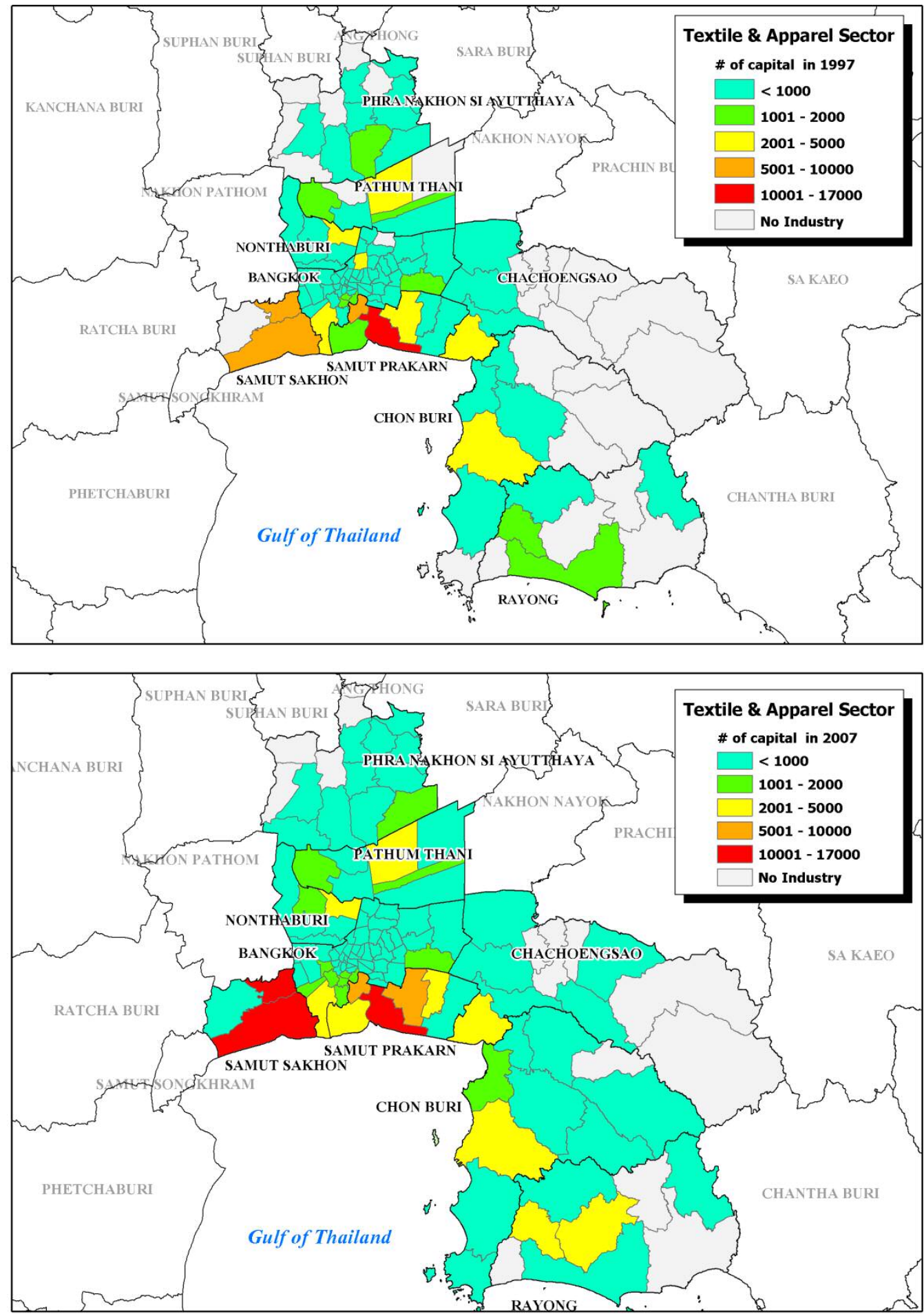
Figure 0.35: Skill composition in textile industry

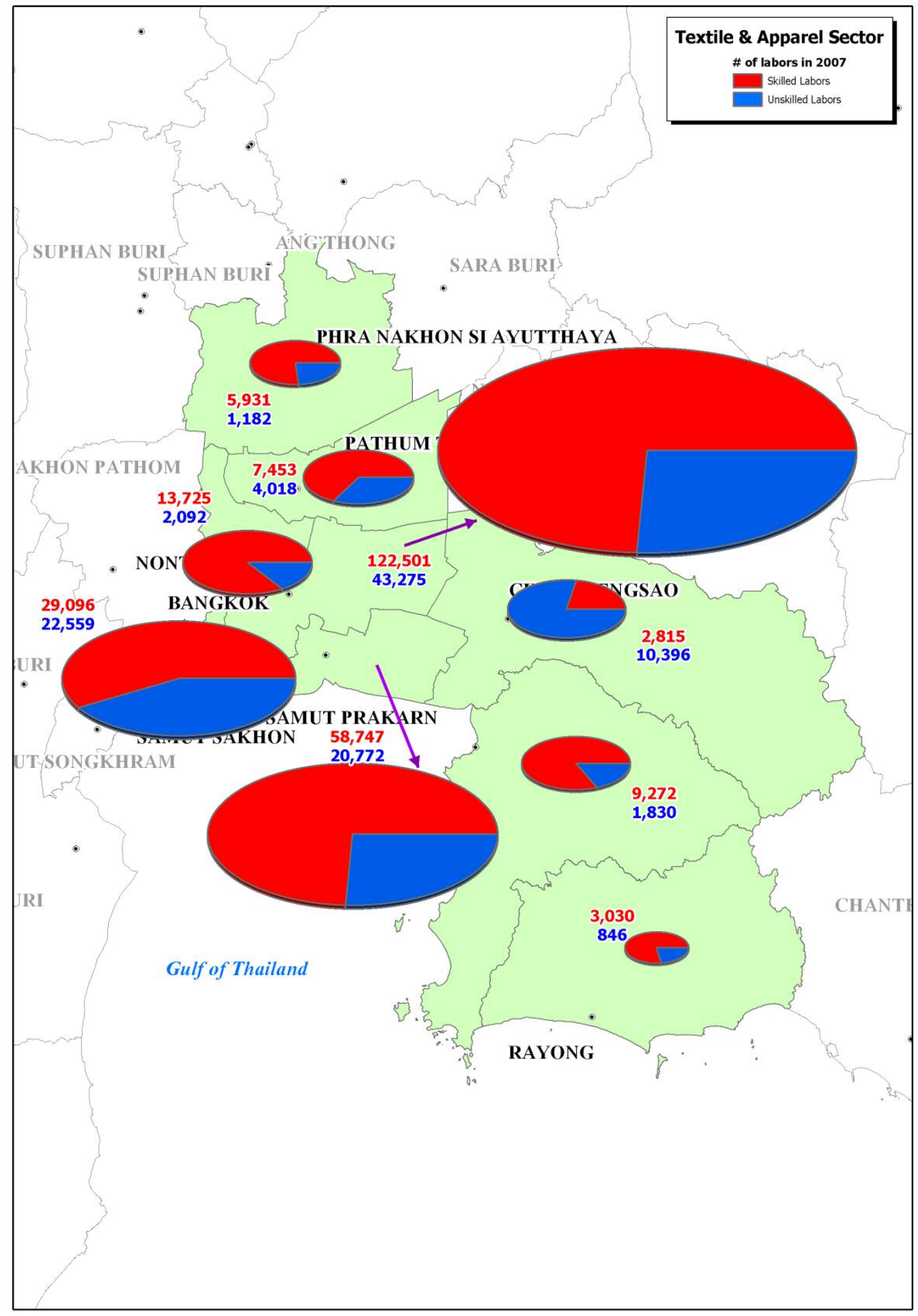




\section{Printing and Publishing Industry}

As Bangkok's industrial composition shifts towards services, there is a rising demand of services in the core areas that has attracted printing and publishing firms to the city and its vicinity. The industry appears to be consolidating with Bangkok's share of establishments diminishing, while the share of output and employment has increased. The industry now accounts for half of the employment and output in services (see Table 0.10 and Table 0.11). It is clear from Figure 0.36 that Bangkok is the center of the printing and publishing industry. While firms are being established in other provinces, Bangkok attracted more than 2,000 new entries between 1997 and 2007 (see Figure 0.38).

The gross output of Bangkok in this industry is close to 60 billion baht, accounting for $72 \%$ of the national output and 70 percent of the national workforce is located in the Bangkok region. While other provinces, notably Samut Prakarn, Nonthaburi, and Chonburi, saw an increase in the numbers of new firms and in employment (see Figure 0.37 , Figure 0.38 , Figure 0.39 and Figure 0.40 ), their employment is trivial compared to the more than 54,000 people engaged in printing and publishing in Bangkok. Investment is also centered in Bangkok and in Samut Prakarn (sees Figure 0.41).

Printing and publishing being a high value adding mainly urban activity, the share of skilled workers is commensurately greater with $77 \%$ of workers considered as being skilled. The share of skilled workers in Bangkok (75\%) is close to that of national average (see Figure 0.42). The share of skilled workers is higher in Chonburi (91\%), Samut Sakhon (81\%), and Rayong (79\%). 
Table 0.10: Bangkok and Vicinity Share of National Total in Services

\begin{tabular}{lccr}
\hline & $\begin{array}{c}\text { Number of } \\
\text { Establishments }\end{array}$ & $\begin{array}{c}\text { Number of } \\
\text { Employees }\end{array}$ & $\begin{array}{r}\text { Value Added (in } \\
\text { thousand baht) }\end{array}$ \\
\hline $\mathbf{2 0 0 0}$ & & & \\
Bangkok and Vicinity & 20,868 & 120,768 & $44,330,141$ \\
National Total & 22,234 & 731,171 & $314,179,079$ \\
Share & $\mathbf{9 3 . 9 \%}$ & $\mathbf{1 6 . 5 \%}$ & $\mathbf{1 4 . 1 \%}$ \\
$\mathbf{2 0 0 6}$ & & & \\
Bangkok and Vicinity & 301,428 & $1,170,603$ & $741,872,455$ \\
National Total & $1,206,242$ & $2,631,378$ & $1,386,086,760$ \\
Share & $\mathbf{2 5 . 0 \%}$ & $\mathbf{4 4 . 5 \%}$ & $\mathbf{5 3 . 5 \%}$ \\
\hline
\end{tabular}

Table 0.11: Changes in Printing and Publishing Industries, 1997-2007

(values in thousand baht)

\begin{tabular}{lrrrr}
\hline & 1997 & 2007 & Change (\%) & $\begin{array}{r}\text { Average } \\
\text { Growth } \\
\text { Rates (\%) }\end{array}$ \\
\hline Bangkok & & & & \\
Number of Establishments & 691 & 2,713 & $292.6 \%$ & $14.7 \%$ \\
Number of Employees & 38,830 & 54,240 & $39.7 \%$ & $3.4 \%$ \\
Value of Gross Outputs & $53,11,944.9$ & $59,183,417.1$ & $11.4 \%$ & $1.1 \%$ \\
Book Value of Fixed Assets & $23,437,479.6$ & $29,557,628.7$ & $26.1 \%$ & $2.3 \%$ \\
& & & & \\
Vicinity & & & & \\
Number of Establishments & & & $731.0 \%$ & $23.6 \%$ \\
Number of Employees & 4,771 & 14,596 & $205.9 \%$ & $11.8 \%$ \\
Value of Gross Outputs & $4,322,257.0$ & $17,763,893.6$ & $311.0 \%$ & $15.2 \%$ \\
Book Value of Fixed Assets & $2,281,463.4$ & $9,149,674.1$ & $301.0 \%$ & $14.9 \%$ \\
& & & & \\
National Total & & & & \\
Number of Establishments & 915 & 5,949 & $550.2 \%$ & $20.6 \%$ \\
Number of Employees & 47,570 & 80,709 & $69.7 \%$ & $5.4 \%$ \\
Value of Gross Outputs & $59,469,244.0$ & $83,366,707.5$ & $40.2 \%$ & $3.4 \%$ \\
Book Value of Fixed Assets & $27,626,739.8$ & $49,076,530.1$ & $77.6 \%$ & $5.9 \%$ \\
\hline
\end{tabular}


Figure 0.36: Number of establishments in printing and publishing at province level
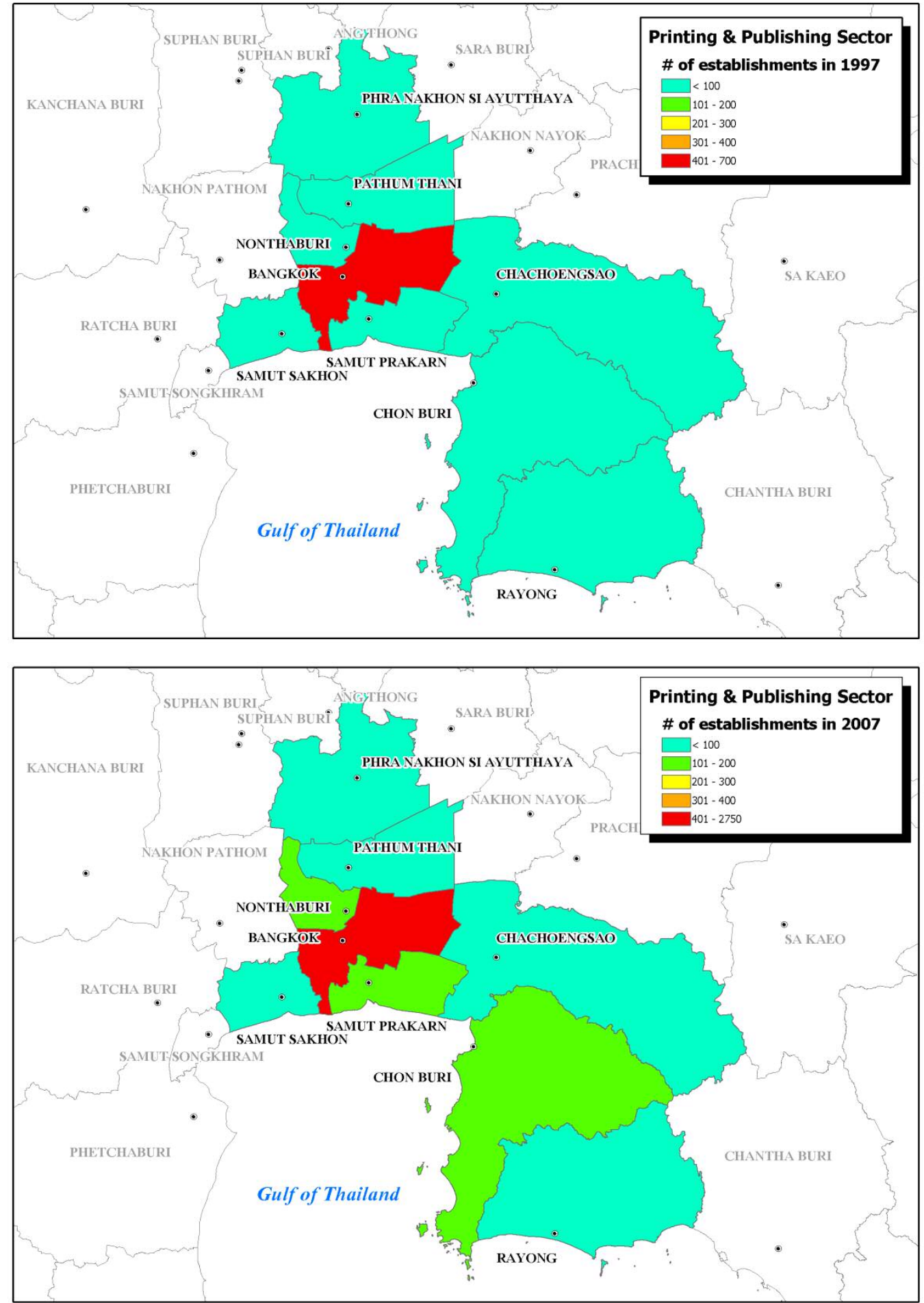
Figure 0.37: Number of establishments in printing and publishing at district level
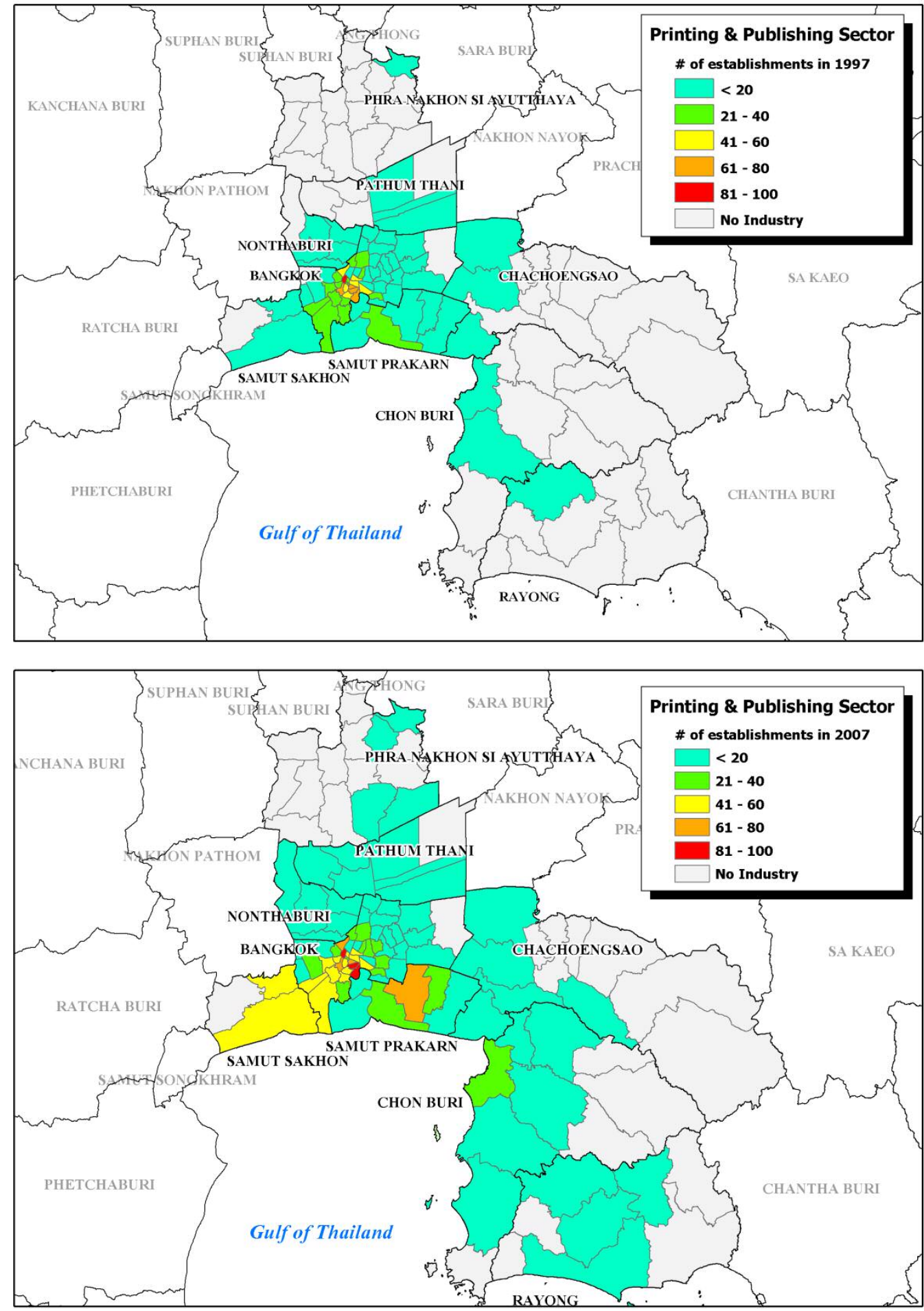
Figure 0.38: New entries in printing and publishing industry

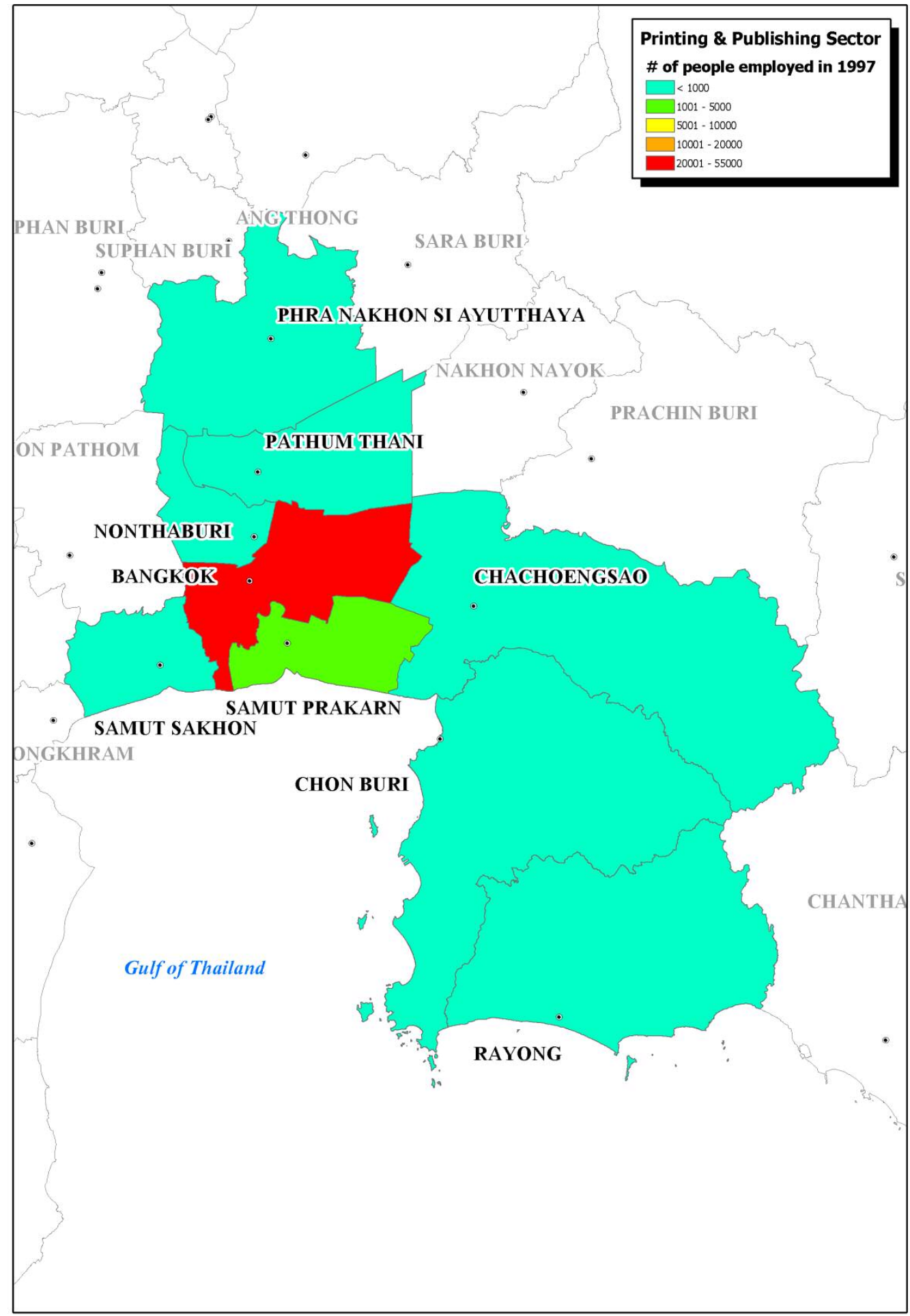


Figure 0.39: Gross outputs of printing and publishing industry
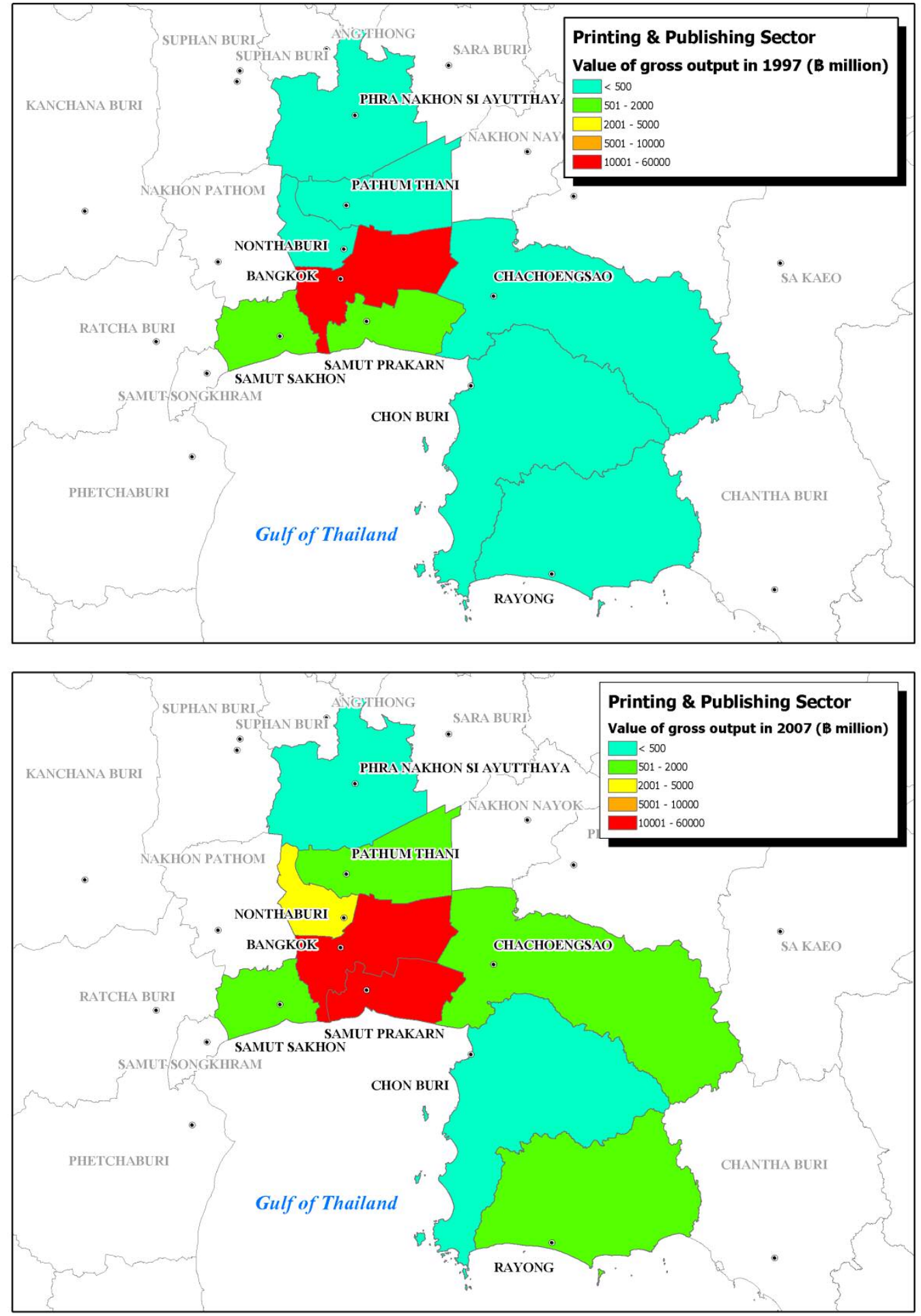
Figure 0.40: Employment in printing and publishing industry
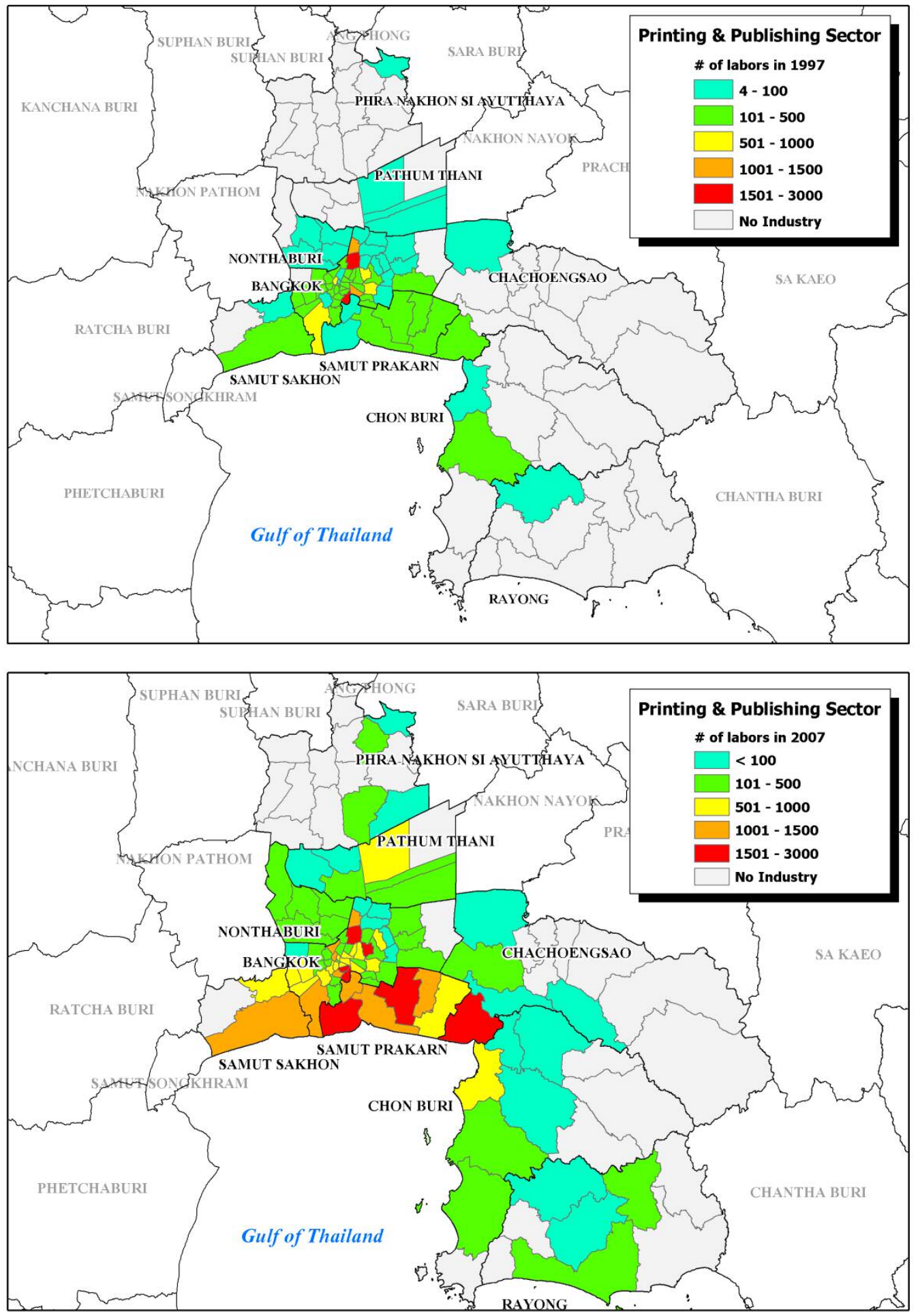
Figure 0.41: Investment in printing and publishing industry
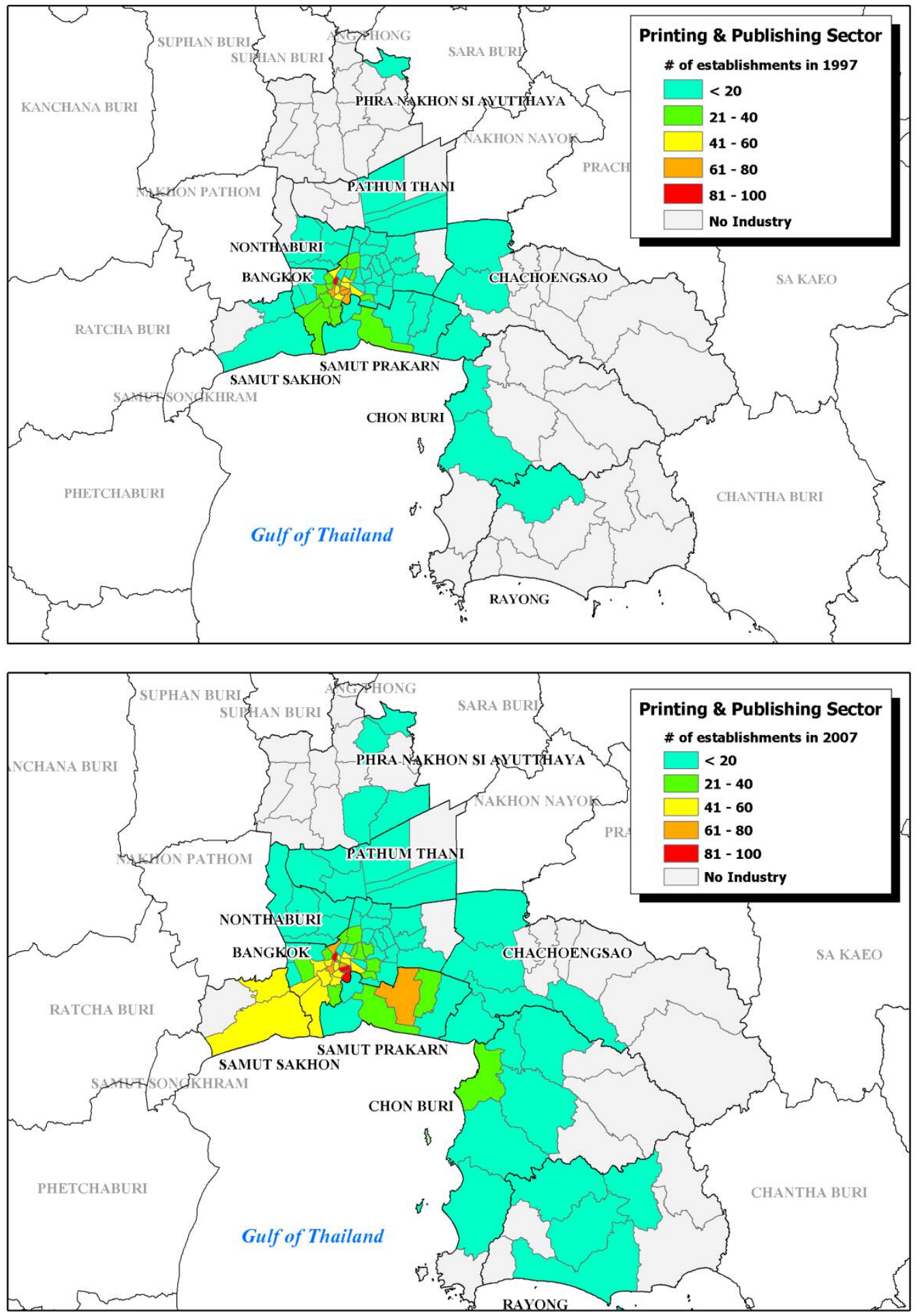
Figure 0.42: Skill composition in printing and publishing industry

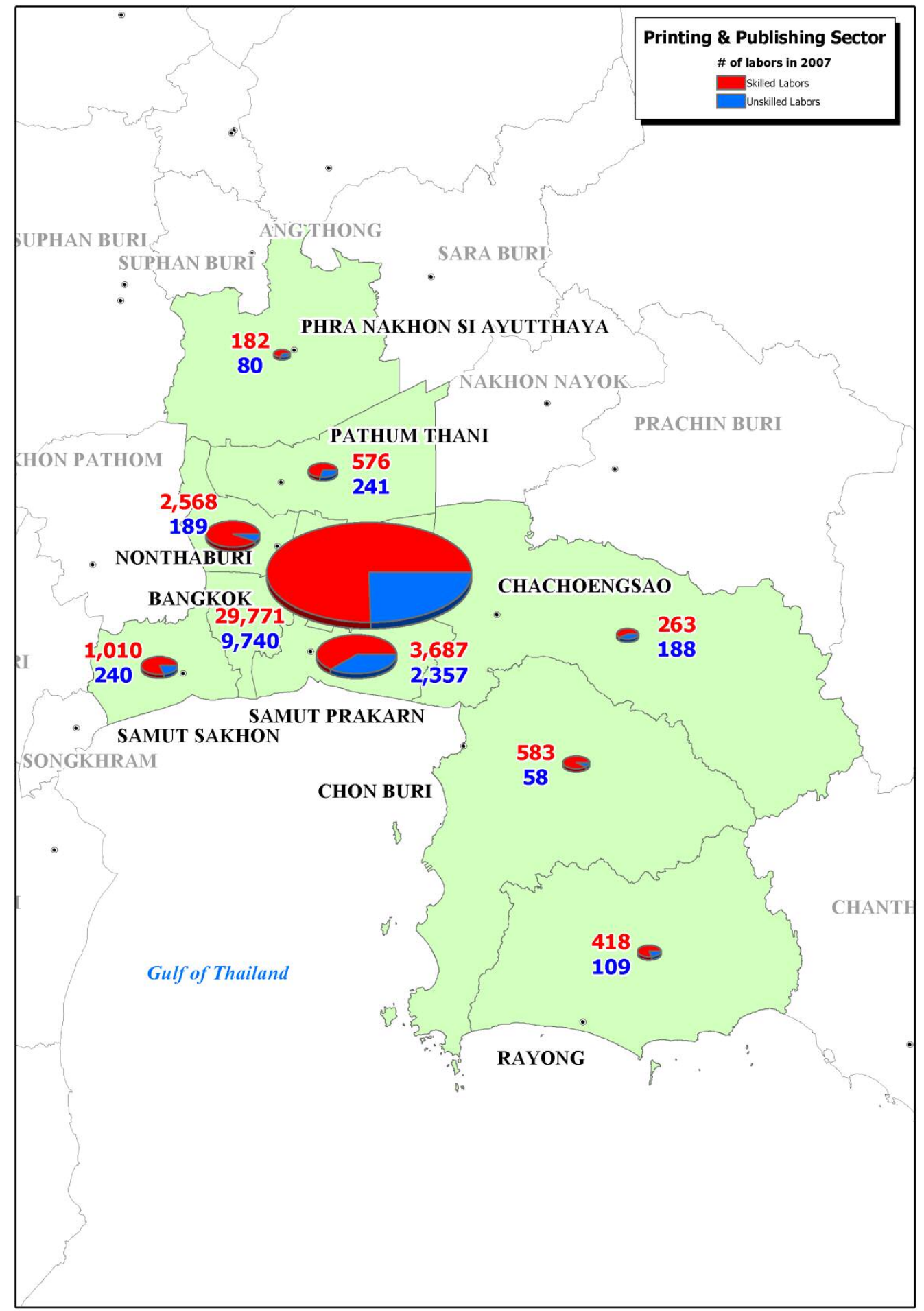




\section{Trends in industrial activities in Bangkok and the Vicinity}

With the exception of the auto parts industry, each of the other major industries has increased the number of establishments, employment, and gross output in Bangkok. The largest increase in the manufacturing sectors was in the garments and textile industry, followed by metal working and food processing. The printing and publishing industry registered the largest gains in the services sector. Although there was some increase in the number of electronics firms in Bangkok, in terms of output, Bangkok is no longer the dominant location for electronics production in Thailand. Among the provinces in the urban region, the gross output of Ayutthaya was the highest with 273 billion baht, accounting for $28 \%$ of the national output ${ }^{31}$. The shift in the center of gravity of the automotive industry has increased the output of Chonburi to 135 billion baht surpassing that of Bangkok (105 billion baht). Similarly, as noted above other manufacturing activities are gradually moving out from Bangkok to Pathum Thani and Ayutthaya to the northeast and Samut Sakhon and Samut Prakarn to the south. The emerging industrial concentration in Ayutthaya and Pathum Thani is related to the existence of industrial estates. The agglomeration of firms in Samut Sakhon and Samut Prakarn is also linked to the creation of industrial estates as well as the geographical advantage of coastal locations and access to ports, and proximity to the major market (Bangkok).

In the last 10 years, the growth of business services in Bangkok has been little short of phenomenal (see Table 0.12). Activities such as research and experimental development, market research, and architectural services are all concentrated in the Bangkok area (see Table 0.13). Close to half of firms engaged in accounting and labor recruitment are also located in Bangkok.

\footnotetext{
${ }^{31}$ See also Webster (2004, pp. 104-5).
} 
Table 0.12: Changes in Services Subsectors in Bangkok, 2000-2006

\begin{tabular}{|c|c|c|c|c|}
\hline Subsector & $\begin{array}{c}\text { Number of } \\
\text { Establishments }\end{array}$ & $\begin{array}{l}\text { Number of } \\
\text { Employees }\end{array}$ & $\begin{array}{l}\text { Value } \\
\text { Added }\end{array}$ & $\begin{array}{l}\text { Book Value of } \\
\text { Fixed Assets }\end{array}$ \\
\hline Real estate activities & $1487.8 \%$ & $1128.6 \%$ & $3638.3 \%$ & $1512.1 \%$ \\
\hline Hardware consultancy & $1287.3 \%$ & $2095.0 \%$ & $93393.5 \%$ & $2450.9 \%$ \\
\hline Legal activities & $285.2 \%$ & $583.9 \%$ & $3158.2 \%$ & $164.8 \%$ \\
\hline $\begin{array}{l}\text { Accounting, book-keeping } \\
\text { and auditing activities, tax } \\
\text { consultancy }\end{array}$ & $340.0 \%$ & $564.5 \%$ & $499.2 \%$ & $27.2 \%$ \\
\hline $\begin{array}{l}\text { Market research and public } \\
\text { opinion polling }\end{array}$ & $604.9 \%$ & $1837.2 \%$ & $6692.8 \%$ & $4305.3 \%$ \\
\hline $\begin{array}{l}\text { Architectural and } \\
\text { engineering activities and } \\
\text { related technical consultancy }\end{array}$ & $263.5 \%$ & $995.3 \%$ & $1255.5 \%$ & $1034.6 \%$ \\
\hline Advertising & $452.3 \%$ & $728.6 \%$ & $976.9 \%$ & $250.4 \%$ \\
\hline $\begin{array}{l}\text { Labor recruitment and } \\
\text { provision of personnel }\end{array}$ & $297.1 \%$ & $977.5 \%$ & $3758.0 \%$ & $-55.2 \%$ \\
\hline
\end{tabular}

Table 0.13: Bangkok's shares in selected services sectors, 2006

\begin{tabular}{lrrr}
\hline & $\begin{array}{r}\text { Number of } \\
\text { Establishments }\end{array}$ & Employment & $\begin{array}{r}\text { Value } \\
\text { Added }\end{array}$ \\
\hline Real estate activities & $33.8 \%$ & $62.0 \%$ & $74.5 \%$ \\
(IT) Hardware consultancy & $37.2 \%$ & $76.2 \%$ & $78.9 \%$ \\
Research and experimental development & $90.0 \%$ & $92.9 \%$ & $80.8 \%$ \\
Legal activities & $30.6 \%$ & $63.8 \%$ & $69.7 \%$ \\
Accounting, book-keeping and auditing activities, tax & $49.5 \%$ & $62.6 \%$ & $75.4 \%$ \\
consultancy & $81.6 \%$ & $87.5 \%$ & $93.2 \%$ \\
Market research and public opinion polling & $64.5 \%$ & $83.3 \%$ & $91.1 \%$ \\
Architectural and engineering activities and related & $28.2 \%$ & $71.3 \%$ & $86.0 \%$ \\
technical consultancy & $53.9 \%$ & $37.0 \%$ & $44.4 \%$ \\
Advertising & & & \\
Labor recruitment and provision of personnel & & &
\end{tabular}

While the growth of services sectors in the vicinity has been as impressive or even in some instances, surpasses that of Bangkok, it is from a low base (see Table 0.14). The national share of services industries in the vicinity is still quite modest (see Table 0.15). Labor recruitment services are the only exception. These cater to the needs of firms, especially manufacturing firms, and therefore tend to locate close to or within the industrial estates, that tend to be outside of Bangkok. 
Table 0.14: Changes in Services Subsectors in Vicinity, 2000-2006

\begin{tabular}{lcccc}
\hline Subsector & $\begin{array}{c}\text { Number of } \\
\text { Establishments }\end{array}$ & $\begin{array}{c}\text { Number of } \\
\text { Employees }\end{array}$ & $\begin{array}{c}\text { Value } \\
\text { Added }\end{array}$ & $\begin{array}{c}\text { Book Value } \\
\text { of Fixed } \\
\text { Assets }\end{array}$ \\
\hline $\begin{array}{l}\text { Real estate activities } \\
\text { Legal activities }\end{array}$ & $7719.3 \%$ & $978.3 \%$ & $2482.6 \%$ & $903.6 \%$ \\
$\begin{array}{l}\text { Accounting, book-keeping and } \\
\text { auditing activities, tax } \\
\text { consultancy }\end{array}$ & $1717.6 \%$ & $2470.6 \%$ & $5938.9 \%$ & $752.5 \%$ \\
$\begin{array}{l}\text { Advertising } \\
\begin{array}{l}\text { Labor recruitment and } \\
\text { provision of personnel }\end{array}\end{array}$ & $535.3 \%$ & $421.8 \%$ & $490.9 \%$ & $\mathrm{n} / \mathrm{a}$ \\
\hline
\end{tabular}

Table 0.15: Vicinity's shares in selected services sectors, 2006

\begin{tabular}{lrrr}
\hline & $\begin{array}{c}\text { Number of } \\
\text { Establishments }\end{array}$ & $\begin{array}{c}\text { Employment } \\
\text { Value Added }\end{array}$ \\
\hline Real estate activities & $19.5 \%$ & $7.6 \%$ & $5.6 \%$ \\
Hardware consultancy & $7.8 \%$ & $3.3 \%$ & $5.1 \%$ \\
Research and experimental development & $10.0 \%$ & $7.1 \%$ & - \\
Legal activities & $8.0 \%$ & $13.4 \%$ & $6.9 \%$ \\
Accounting, book-keeping and auditing activities, tax & $7.6 \%$ & $6.4 \%$ & $4.5 \%$ \\
consultancy & $7.0 \%$ & $2.7 \%$ & $1.0 \%$ \\
Market research and public opinion polling & $7.3 \%$ & $5.6 \%$ & $3.4 \%$ \\
Architectural and engineering activities and related & $7.7 \%$ & $7.6 \%$ & $6.3 \%$ \\
technical consultancy & $10.4 \%$ & $32.9 \%$ & $22.0 \%$ \\
Advertising & & & \\
Labor recruitment and provision of personnel & & &
\end{tabular}

Overall, the evolution of Bangkok follows the pattern of other major cities. Its initial growth was largely paced by industrialization. However, rising congestion and pollution in the core city, eventually began forcing manufacturing industry, especially for massmanufactured goods requiring large factory spaces to migrate to the surrounding areas. This is not to say that Bangkok is being denuded of manufacturing. New firms are continuously entering, except for some subsectors such as auto parts and electronics. However, many of these firms in food processing or textiles are relatively small, the capital invested in them is modest and they do not generate as much employment as their numbers suggest ${ }^{32}$. Slow growth in the number of new jobs in manufacturing is also apparent in the vicinity. While there were many new entries in all manufacturing subsectors included in this study, the rate of increase in employment lagged the rate of growth in the numbers of firms and output.

\footnotetext{
${ }^{32}$ Worldwide, manufacturing is generating relatively few jobs compared to services because of changing technologies and work practices which tend to conserve labor.
} 
Services industries are now the largest employers and the dominant producers in Bangkok. This concentration of services is likely to continue alongside some further thinning of manufacturing. 


\section{Annex}

Figure 0.43: Industrial Estates / Industrial Parks / Industrial Zones

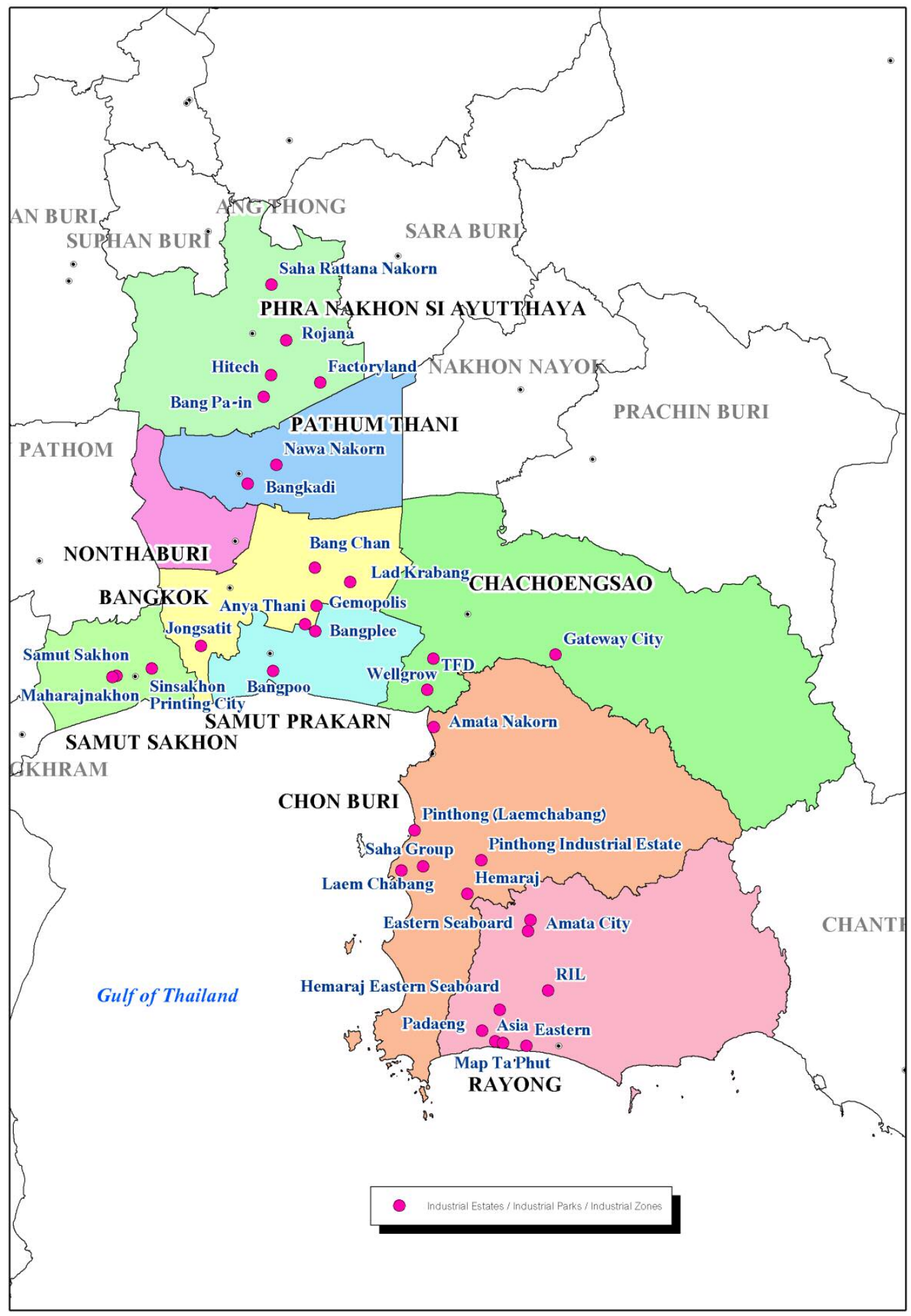





\section{: Industrial Dynamics}

International experience suggests that the growth of successful long lived industrial agglomerations is associated with the presence of specific nuclei. For example, proximity to a major city is an advantage because it provides a ready market, infrastructure, housing, labor supply, sources of financing, technological spillovers and productivity gains arising from agglomeration. World class universities can generate a flow of ideas and research as well as a supply of highly trained and entrepreneurial graduates who help to realize the commercial potential of these ideas. Major anchor firms also can be a source of commercializable ideas, demand for products and services, spin-off firms or start-ups by former employees, and a beacon drawing other companies to the area. The availability of business services, logistics providers and risk capital is necessary in order to strengthen the aggregative potential of other nuclei (see Yusuf, Nabeshima and Yamashita 2008). Undoubtedly, governments, central and local may need to take the initiative by defining a strategy and mobilizing support and they can buttress this by fiscal incentives as well as by developing industrial parks, incubators, training facilities and the physical infrastructure (in particular transport, energy and ICT) industry requires. However, much hangs on the response of the business sector and the success of its efforts to enhance competitiveness.

The role of these attractors is well understood and policy makers attempting to harness the growth potential of industrial clusters seek to assemble as many of the mediating factors as possible. But success is also a matter of chance abetted by persistence modulated by learning and incremental adjustment of the cluster development business model. Most top down attempts at establishing clusters fail outright or are only partially realized because the mix of ingredients does not work and policy efforts fizzle out. In those instances where enough industry takes root but local "clustering" does not occur, policy makers need to decide whether this is a satisfactory outcome given the nature of the industry of technology and the opportunities for global networking or whether an additional policy push is desirable to stir in some missing ingredients. What international experience reveals and Thai experience to date appears to validate is that governments can give cluster formation a push but whether clustering occurs is dependent on many other factors and on chance events. Moreover, at earlier stages of development clustering might be a loose phenomenon. The issue is whether the absence of tightly networked clusters means that significant opportunities for raising productivity and competitiveness are being lost. And if so, can anything be done to induce clustering.

Establishing an industrial estate is one frequently used intervention to start a cluster, especially for a new industry (for a country or a region), such as the automotive industry. This was not feasible with an old established industry such as textiles, because most firms 
had already set up their manufacturing facilities and therefore, would not want to move to another location unless there are sufficiently compelling reasons or incentives to do so. ${ }^{33}$ However, with auto parts and assembly, a relatively new industry, industrial parks offered a means of fixing a location and providing the building blocks for a cluster. As it later turned out, the parks attracted MNCs but many local manufacturers were inhibited from joining them and their foreign suppliers because small and medium firms feared losing their best workers to the MNCs. For small businesses this risk outweighed the benefits of locating in an industrial estate.

The details on the location of establishments and on employment presented in section 2 provide two important pieces of information. First, they delineate the spatial geography of industrialization in the Bangkok urban region over a ten year period with a focus on the major manufacturing and services activities. They highlight the diffusion of some manufacturing activities away from the core urban areas, their concentration in cities closer to the Eastern Seaboard and the changes in these concentrations. Second, they show that the numbers of establishments in several locations rose between 1996 and 2006 as did production. In this section we use the survey results to determine whether the spatial geography that has emerged over the past decade is a stepping stone to a more dynamic and clustered grouping of firms that could underpin faster growth.

\section{Location choice of firms in Bangkok}

In attempting to answer this question, the survey conducted by TDRI provides some insights into perceptions of firms and the motivations underlying their actions. It adds depth and detail to the developments revealed by the maps.

The dispersion of industry from Bangkok to the provinces in the vicinity was a part of an effort to combat congestion in the core urban areas, to reduce pollution (air and noise), and to encourage industrial expansion outside of the Bangkok urban region. There does not appear to have been a conscious policy to create clusters. The government took the lead in establishing a number of industrial estates in conjunction with the Eastern Seaboard development centered on the port of Laem Chabang and by building the road infrastructure linking the estates to the port and to central Bangkok. External connectivity of the region was further improved by the construction of a second international airport called Suvarnabhumi in Bang Phli district, Samut Prakarn Province, $25 \mathrm{~km}$ east of Bangkok. In addition, the recently constructed Chonburi Motorway and Bangkok's outer ring road have significantly improved the links between industries and with downtown Bangkok. Infrastructure has a major bearing on locational choice of factories with firms choosing locations with good transportation networks for easier

\footnotetext{
${ }^{33}$ Food processing firms also tend to locate in a more scattered fashion, because there is little need for close interaction among them.
} 
transportation of raw materials and finished goods. ${ }^{34}$ The majority of firms responded that distance to ports or airports are an important consideration when choosing a factory location (see

Table 0.1).

Table 0.1: Importance of distance to ports and airports

\begin{tabular}{lc} 
Importance & No. of answers \\
\hline Yes, because of & 61 \\
Exporting goods & 35 \\
Convenient transportation & 10 \\
Imported raw materials & 16 \\
No & 18 \\
\hline
\end{tabular}

Source: TDRI 2009

The filling out of the transport network in the Bangkok region has been loosely coordinated with the creation of industrial estates. In all, the Industrial Estate Authority of Thailand (IEAT) has established 12 estates and contracted with private developers for another 26. Many other estates are owned and run by private developers. These estates by offering infrastructure, waste management and water and electricity, have emerged as industrial nodes but the response from firms has been mixed. Many foreign owned firms and joint ventures which put a premium on the services and the security provided by the estates have chosen to locate there. Foreign firms are also lured to the industrial estates by the incentives offered by the Board of Investment (BOI) (see

Table 0.2). Thai firms tend to locate outside of the industrial estates because they are more sensitive to the costs of operating in the estates (see Table 4.3). Land prices in industrial estates being steeper because they include fees for utilities. ${ }^{35}$

\footnotetext{
${ }^{34}$ Firms identified having multiple routes to their factory as an important consideration to ensure access to their factories when other roads are blocked.

${ }^{35}$ Small and medium sized enterprises often do not require large spaces and use little electricity and water. Therefore, these firms prefer to locate outside of an industrial estate, although they seem to prefer locating near to an industrial estate. In addition, environmental regulations are not enforced as strictly outside of the industrial estate.
} 
Table 0.2: Incentives offered by BOI

\begin{tabular}{|c|c|c|c|c|c|c|c|c|}
\hline \multirow[t]{2}{*}{ Privileges } & \multicolumn{2}{|c|}{ Zone 1} & \multicolumn{2}{|c|}{ Zone 2} & \multicolumn{2}{|c|}{$\begin{array}{c}\text { Zone } 3 \\
36 \text { provinces and } \\
\text { industrial estates } \\
\text { in Rayong, } \\
\text { including Lam } \\
\text { Chabang }\end{array}$} & \multicolumn{2}{|c|}{$\begin{array}{c}\text { Zone } 3 \\
22 \text { provinces }\end{array}$} \\
\hline & Inside & Outside & Inside & Outside & Inside & $\begin{array}{c}\text { Outsid } \\
\mathrm{e}\end{array}$ & Inside & Outside \\
\hline $\begin{array}{l}\text { Machinery } \\
\text { tax }\end{array}$ & $\begin{array}{c}50 \% \\
\text { reduction }\end{array}$ & $\begin{array}{c}50 \% \\
\text { reductio } \\
\mathrm{n}\end{array}$ & $\begin{array}{l}\text { Exem } \\
\text { ption }\end{array}$ & $\begin{array}{l}50 \% \\
\text { reduction }\end{array}$ & $\begin{array}{l}\text { Exempti } \\
\text { on }\end{array}$ & $\begin{array}{l}\text { Exemp } \\
\text { tion }\end{array}$ & $\begin{array}{l}\text { Exemp } \\
\text { tion }\end{array}$ & $\begin{array}{c}\text { Exempti } \\
\text { on }\end{array}$ \\
\hline Income tax & 3 years & - & $\begin{array}{c}7 \\
\text { years }\end{array}$ & 3 years & 8 years* & $\begin{array}{c}8 \\
\text { years }\end{array}$ & 8 years & 8 years \\
\hline $\begin{array}{l}\text { Raw material } \\
\text { for export }\end{array}$ & $\begin{array}{c}1 \text { year } \\
\text { Exemptio } \\
n\end{array}$ & $\begin{array}{c}1 \text { year } \\
\text { Exempti } \\
\text { on }\end{array}$ & $\begin{array}{l}1 \text { year } \\
\text { Exem } \\
\text { ption }\end{array}$ & $\begin{array}{c}5 \text { year } \\
\text { Exemptio } \\
n\end{array}$ & $\begin{array}{c}5 \text { year } \\
\text { Exempti } \\
\text { on }\end{array}$ & $\begin{array}{l}5 \text { year } \\
\text { Exemp } \\
\text { tion }\end{array}$ & $\begin{array}{l}5 \text { year } \\
\text { Exemp } \\
\text { tion }\end{array}$ & $\begin{array}{c}5 \text { year } \\
\text { Exempti } \\
\text { on }\end{array}$ \\
\hline $\begin{array}{l}50 \% \text { income } \\
\text { tax reduction } \\
\text { for } 5 \text { year }\end{array}$ & - & - & - & - & I & - & I & I \\
\hline $\begin{array}{l}\text { Transport, } \\
\text { electricity, } \\
\text { water fee } \\
\text { double } \\
\text { reduction }\end{array}$ & - & - & - & - & I & - & I & I \\
\hline $\begin{array}{c}\text { Facilities } \\
\text { installation } \\
\text { fee reduction }\end{array}$ & - & - & - & - & / & I & / & I \\
\hline $\begin{array}{l}\text { Raw material } \\
\text { for domestic } \\
\text { consumption }\end{array}$ & - & - & - & - & l** & /*** & & \\
\hline
\end{tabular}

Note: *Including Lam Chabang Industrial estate and other industrial zones in Rayong $* * 75 \%$ reduction every year, but not more than 5 years (excluding Lam Chabang Industrial estate and other industrial zones in Rayong)

$* * * 75 \%$ reduction every year, but not more than 5 years

Source: TDRI 2009 
Table 0.3: Locations of companies separated by the nationalities and sizes

\begin{tabular}{|l|c|c|c|}
\hline \multirow{2}{*}{ Nationalities } & \multirow{2}{*}{ Size } & \multicolumn{2}{|c|}{ Locations } \\
\cline { 3 - 4 } & & In industrial estates & Outside industrial estates \\
\hline Thai & Total & 5 & 32 \\
& $\mathrm{~S}$ & 2 & 17 \\
& $\mathrm{M}$ & 2 & 8 \\
& $\mathrm{~L}$ & 1 & 7 \\
\hline Foreign & Total & 13 & 6 \\
& $\mathrm{~S}$ & 2 & 2 \\
& $\mathrm{M}$ & 7 & 3 \\
& $\mathrm{~L}$ & 4 & 1 \\
\hline Joint Venture between Thai and & Total & 28 & 4 \\
foreign companies & $\mathrm{S}$ & 4 & 1 \\
& $\mathrm{M}$ & 9 & 3 \\
\hline Total & $\mathrm{L}$ & 15 & 42 \\
\hline
\end{tabular}

Source: TDRI 2009

The quality of the services provided by the industrial estates tends to vary with many firms complaining of power outages, interruptions of the water supply, and of the poor quality of roads in and around the estates. ${ }^{36}$ On balance though, the occupants of the estates are reasonably content with the cost and quality of the services and with the transport links to Bangkok. For example, four-fifth of firms surveyed consider the transportation infrastructure connecting their factories and downtown Bangkok and/or airports and ports as adequate (see Almost a third of the survey respondents indicated that their decision to locate in an industrial estate was influenced by the convenience and in their view, cost effective access to good quality energy, water, and communication infrastructure.

Figure 0.1). Among those which are concerned about the deficiencies, automotive firms are the most vocal. This is because automotive firms rely on just-in-time delivery system to limit the stock of inventories at factory sites. Their reliance on frequent deliveries magnifies the shortcomings of the transportation network. Regulations prohibiting trucks from operating during certain times of the day in Bangkok, also require firms to schedule deliveries during off-peak hours and this raises the costs because drivers need to be paid overtime wages.

\footnotetext{
${ }^{36}$ Among the disadvantages of industrial areas cited by the respondents are uneven road surfaces, frequent power outages, and drainage problems. Uneven surface roads are particularly problematic since final goods can be damaged during transportation. Also a lack of clear zoning rules around industrial estates has led to the development of residential areas that are scattered around the industrial estate, contributing to the conflicts among residents and factory owners. Clearer zoning with sufficient buffer zones between industrial and residential/commercial area could mitigate some of these problems.
} 
Almost a third of the survey respondents indicated that their decision to locate in an industrial estate was influenced by the convenience and in their view, cost effective access to good quality energy, water, and communication infrastructure.

Figure 0.1: Reponses to the question, "Are the cost of production, quality and speed of transport facilities to the centre of Bangkok or airports or ports suitable and sufficient?"

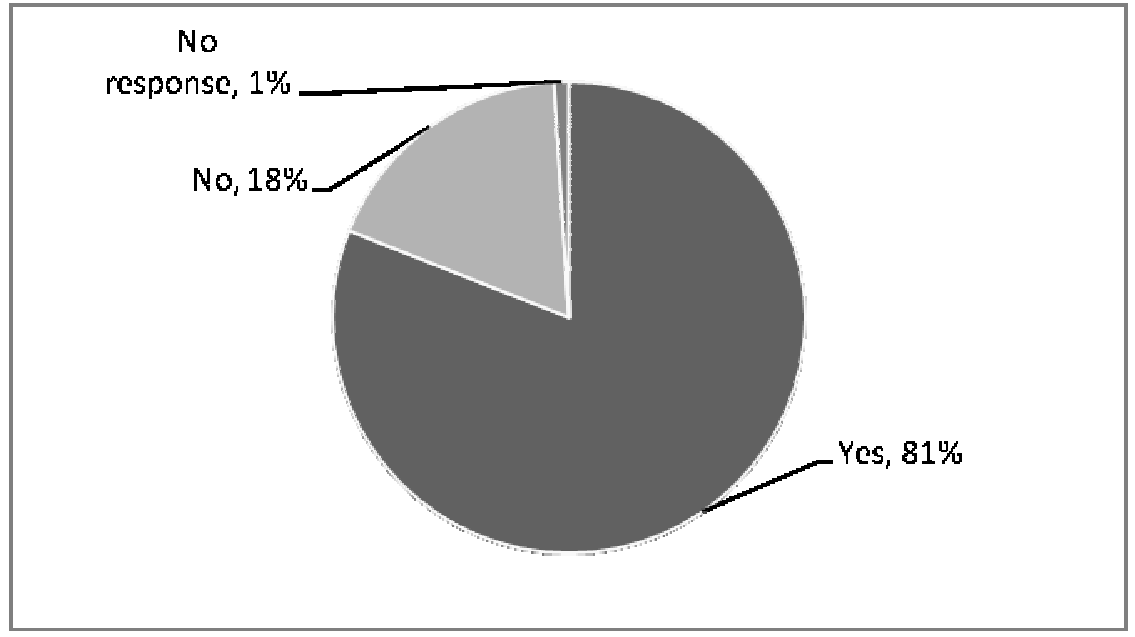

Source: TDRI 2009

Table 0.4: Advantages of choosing to locate plants inside industrial estate

\begin{tabular}{lcc}
\hline Advantages & No. of answers & Percentage \\
\hline Good infrastructures & 26 & 30.2 \\
BOI incentives & 20 & 23.3 \\
Convenient transportation system & 8 & 9.3 \\
Facilities from the industrial estate & 8 & 9.3 \\
Close to customers & 7 & 8.1 \\
Good management & 3 & 3.5 \\
Close to suppliers & 3 & 3.5 \\
Close to raw materials sources & 2 & 2.3 \\
Convenient to transport & 2 & 2.3 \\
Cheap labour wages & 2 & 2.3 \\
Close to government agencies & 1 & 1.2 \\
Close to Bangkok & 1 & 1.2 \\
Low logistics costs & 1 & 1.2 \\
Close to transport hubs & 1 & 1.2 \\
Many benefits from industrial estates & 1 & 1.2 \\
Total & 86 & 100.0 \\
\hline
\end{tabular}

Source: TDRI 2009

Firms located outside of the industrial estate suffer far more from power outages and must put up with inadequate telecommunications. Internet connections are particularly unreliable outside of the estates. Most firms outside of the estates cannot access piped 
water from the municipality and instead rely on ground water which they need to filter and the disposal of which is a source of pollution. ${ }^{37}$ The case of Map Ta Phut has highlighted the seriousness of the environmental issues. ${ }^{38}$

Thus far there is little evidence to suggest that industrial estates have promoted cluster formation. ${ }^{39}$ Many firms in the metro areas of Bangkok have not chosen to relocate because of the cost and the inconvenience, and because of the strong "pull" exerted by the Bangkok metro area which is the most important domestic market for manufacturers (see Table 0.5).

\section{Table 0.5: Importance of distance to Bangkok}

\begin{tabular}{lc} 
Importance & No. of answers \\
\hline Yes, because & 60 \\
Customers are located in Bangkok & 23 \\
Close to headquarters & 8 \\
Close to transportation point & 5 \\
Suppliers are in Bangkok & 4 \\
Have to contact with government authorities & 4 \\
Convenient for executives & 4 \\
Convenient to deal business transactions & 3 \\
Workers are in Bangkok & 2 \\
Difficult to find labors outside Bangkok & 2 \\
Convenient transportation & 2 \\
Customers are in the vicinity areas and Eastern region & 1 \\
Close to home & 1 \\
Reduce cost of production & 1 \\
No & 18 \\
\hline
\end{tabular}

Source: TDRI 2009

\footnotetext{
${ }^{37}$ Often local authorities are inexperienced with pollution control and this leads to a deteriorating environment for the surrounding community. Even if concerns are voiced by the community, the remedy employed may not be appropriate. Such was the case in Samut Sakorn, where the local authority simply filled the canal with soil in response to complaints from residents on polluted waters discharged by nearby firms.

${ }^{38}$ Under Thailand's 2007 constitution, industrial projects that might be harmful to people or the community must satisfy strict environmental standards. This entails the preparation of an environmental impact assessment (EIA), a health impact assessment (HIA), and public hearings. As a consequence, a number of companies were unable to comply with HIA requirements in part because successive governments failed to set up the independent body required to assess the health impact. In 2009, a long-running dispute between heavy industries and local residents of Rayong province halted 65 industrial projects in the Map Ta Phut Industrial Estate which the residents claimed were a source of dangerous levels of pollution. Although the impact of the Ma Ta Phut case on investor confidence and the investment climate has been limited, it has further highlighted the need to establish clear and consistent rules for complying with the new requirements. The setting up of several working groups to advise affected companies and restart projects that had stalled, represents a good start and could help to mitigate longer term effects on investor confidence.

${ }^{39}$ A recent article by Neumark and Kolko (2010) indicates that enterprise zones do not increase employment.
} 
A subset of firm mainly Thai owned ones, have located outside of the estates because the services are expensive and environmental regulations more actively enforced. As a consequence, parks have excess capacity: the flow of new entrants is relatively small, and although the population of firms in the vicinity has increased, if we are to believe the GIS data, there have been a sizable number of exits or takeovers of smaller firms by bigger ones leading to a consolidation of production capacity.

Questions regarding future moves by firms in the metro area also elicited mixed responses with some proposing to stay put where they are and others intending to stay in the vicinity of Bangkok even if they do move. Only a minority expressed an interest in moving to an industrial park. Developers also are equivocal as to the future of the industrial sites. They lament the excess supply of space which has put downward pressure on their rents and rates and they worry over ambiguities regarding current zoning laws and uncertainties about future regulations.

Industrial estates and parks have induced some concentration of firms, but production facilities remain fairly dispersed on the fringes of the metro area, in the core city and around the estates. What then are the prospects of future clustering and is that an objective the government should pursue?

\section{Availability and Quality of Labor}

One of the drivers of clustering is the local labor market. A dense pool of skills for firms to draw upon is an important locational advantage. It reduces transaction costs, promotes spillovers which facilitate technology diffusion and lead to broader gains in productivity. When labor market incentives and signals lead to an upgrading in the level and quality of skills, firms are able to move up the technological ladder and to diversify. A reason why firms from all the industries are attracted to the Bangkok region is the ease of recruiting skilled technical and professional workers because one third of all tertiary institutes in Thailand are located in Bangkok (Yilmaz 2009). ${ }^{40}$ Teaching and vocational training institutions are continually adding to the supply and the existing stock remains stable because the vast majority of managers, professionals and other skilled workers prefer to remain in Bangkok so as to benefit from amenities, schooling and services. This applies with even greater force to foreign professionals working for multinationals. Those who are employed in the industrial parks generally prefer to reside in Bangkok rather than move to the satellite cities where many factories have located. ${ }^{41}$

\footnotetext{
${ }^{40}$ Chulalongkorn University ranks 44yh among Asian universities. Others such as Thammasat and Kasetsart rank $91^{\text {st }}$ and $126^{\text {th }}$ respectively (See http://www.topuniversities.com/univeersity-rankings/asianuniversityrankings/overall).

${ }^{41}$ For some firms, especially Japanese MNCs, the location of factories tend to be closer to Bangkok for easier commute of executives who lives in Bangkok. This suggests that amenities and livability around the factory sites are not conducive to attracting these people.
} 
The semi-skilled and unskilled workers are frequently migrants who come without their families to take jobs in factories and live in dormitories or in rental accommodation. Firms inside an industrial estate can find suitable employees for vacancies in shorter time than those located outside. Typically it takes only one week to fill semi-skilled vacancies in industrial estate compared to 14 days outside. As the skill level increases, so also does the number of days required to find suitable employees and the difference between factories located within and outside estates diminishes. For management positions, it takes more than one month, 35 (38) days for firms located within (outside) industrial estate, to fill the position. ${ }^{42}$ However, firms surveyed indicated that high turnover even within an industrial estate as one of the constraints they face, especially for higher skilled positions. These firms rely mainly on labor recruitment offices (including headhunter agencies for management positions) to fill their vacancies (see Figure 0.2). The headhunting agencies are typically located just outside of the industrial estate or at the services center of the industrial estate.

\section{Figure 0.2: Source of employment}

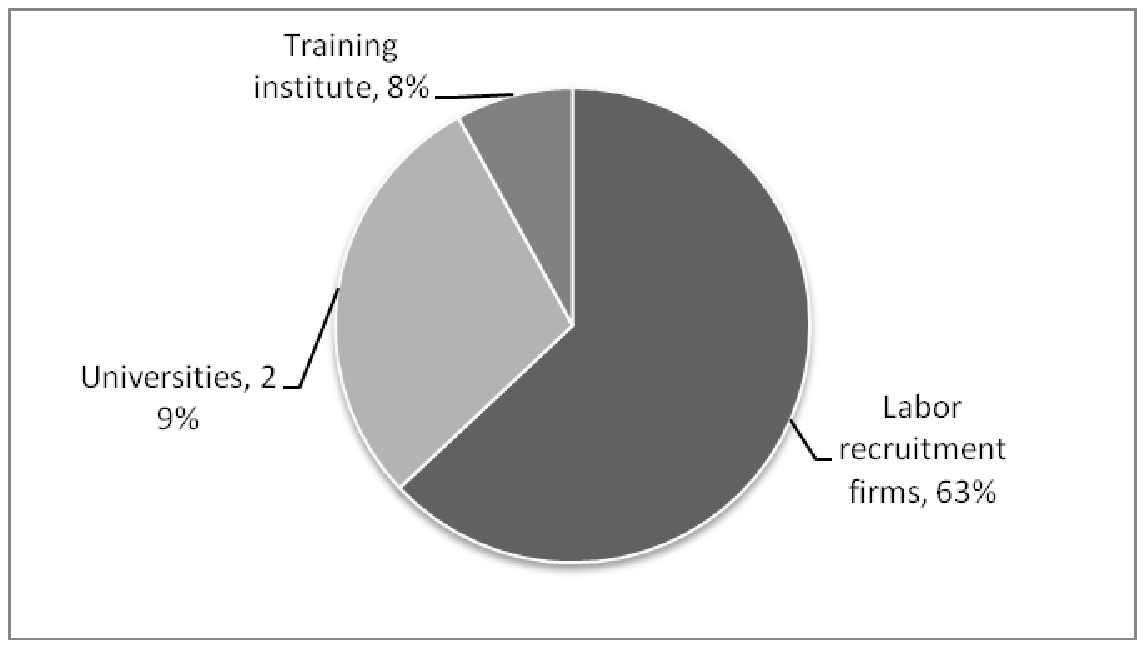

Source: TDRI 2009

The characteristics of the labor market in the urban region are not calculated to induce local cluster formation for three reasons: first, the attractions of Bangkok affect the concentration of high level human capital in the industrial centers to the East of Bangkok. Many who work there are commuters or sojourners with one foot in Bangkok. Second, the semi-skilled workforce is a fluid one which also detracts from the building and accumulation of technical expertise. Third, the widespread and persistent complaint of employers is that the quality of the workforce, semi-skilled or skilled, is poor and has not been improving. Filling vacancies in professional categories takes five to seven weeks in Thailand and the time required is lengthening in recent years. Exporters and MNCs are

\footnotetext{
${ }^{42}$ Firms in the food industry have the hardest time filling management positions, taking more than 50 days.
} 
facing an even more difficult time finding suitable professionals (Yilmaz 2009). Raising the quality of the semi-skilled is hampered by high turnover, weak learning and language capabilities and a lack of non cognitive soft skills. Those with college degrees have a smattering of bookish theoretical knowledge but are unequipped for the practicalities of working in a production facility. If they have had any exposure to the equipment and technology they must deal with in a factory, it is often of German origin, whereas most of the equipment in the production units is Japanese or East Asian. Thus new workers at any level need to go through intensive training ${ }^{43}$. This in itself is not unusual. What does detract from cluster formation in the industrial estates along the eastern rim of the Bangkok urban region is the absence of a strong tendency for the labor market to thicken and for the pool of skills to increase in density. Essentially the same complaints that were being voiced a decade ago are still uppermost and without a significant transformation of local labor markets and parallel efforts at technological upgrading of industry, clustering and associated productivity gains will be difficult to realize. English, IT and numerical skills remain low and proficiency in English has worsened since 2004 (World Bank 2009).

\footnotetext{
${ }^{43}$ Internal training by companies is the main source of skills and companies spend an average of 100,000 Baht per year. In addition companies can spend up to 500,000 baht per year on external training with the auto industry spending the largest amount.
} 


\section{Innovation and Technology transfer}

Thailand's export oriented industrialization and specifically the growth of the electronics and auto manufacturing, has depended upon FDI mainly from East Asia. Foreign firms can serve as the anchor tenants of industrial estates which have attracted many of the major MNCs. These firms do subcontract for certain lower tech categories of products with local suppliers but they do so sparingly. For reasons of convenience, they make an effort to minimize the number of suppliers they deal with and their preference is for suppliers that can meet their requirements worldwide and not just in a single country. Hence, there is a tendency to use suppliers from their home countries, many of which are persuaded to set up a subsidiary or a joint venture in Thailand. This makes for a lean supply chain and minimizes the subcontracting relationships among firms in and around estates. It also raises the entry barriers for domestic suppliers that would contribute to the ripening of a cluster. There are potential anchor firms operating in the Bangkok region but because of the exclusive supply relationships they cultivate, these anchors have not collected around them a critical mass of firms. This also has implications for innovation.

Many firms in Thailand engage in incremental innovation ${ }^{44}$. Among the surveyed firms, more than $50 \%$ of firms in food processing and $40 \%$ of firms in auto and electronics industries have introduced new products in the last five years, indicating that firms are beginning to acquire internal technological capacity (see Figure 0.4). Relative to other firms, those in the food industry have more developmental capabilities (see Figure 0.5 ). Wholly Thai-owned firms in the food industry are active in introducing new products to the market, although many so-called new products only add to the choice of flavours and make small modifications to the packaging ${ }^{45}$. Firms in the auto industry rely on customers (the final assembler and higher tier parts suppliers) for their designs as do electronics firms (see Figure 0.6). ${ }^{46}$ This is to be expected because many of the buyers are major MNCs. However, because 'relational clustering' is weak, very few Thai subcontractors are involved in the design phase of product development, making it harder to introduce new products and designs and in the process acquire the skills and expertise that could lead to movement up the supply chain. There are exceptions however, such as AAPICO Hitech a producer of jigs and dies, fuel tanks and chassis frames and the Summit Group (See World Bank and NESDB 2008).

\footnotetext{
${ }^{44}$ This needs to be treated with caution as the "new" products introduced are usually variants of existing products with a few cosmetic changes. Few firms are geared for innovation.

${ }^{45}$ Giant firms such as CP however, are better placed to innovate.

${ }^{46}$ Half of the sampled $100 \%$-foreign-owned firms in the automobile sector design or upgrade their products with their buyers, while only $10 \%$ do with their suppliers
} 
Figure 0.3: Share of innovating companies in Thailand

\begin{tabular}{lr}
\hline & Share \\
\hline Innovating & $\mathbf{1 1 . 2 \%}$ \\
Product and process innovation & $2.9 \%$ \\
Only product innovation & $4.1 \%$ \\
Only process innovation & $4.3 \%$ \\
\hline
\end{tabular}

Source: Doner and others 2010

Figure 0.4: Proportion of new product introduced in the past 2 and 5 years by industry

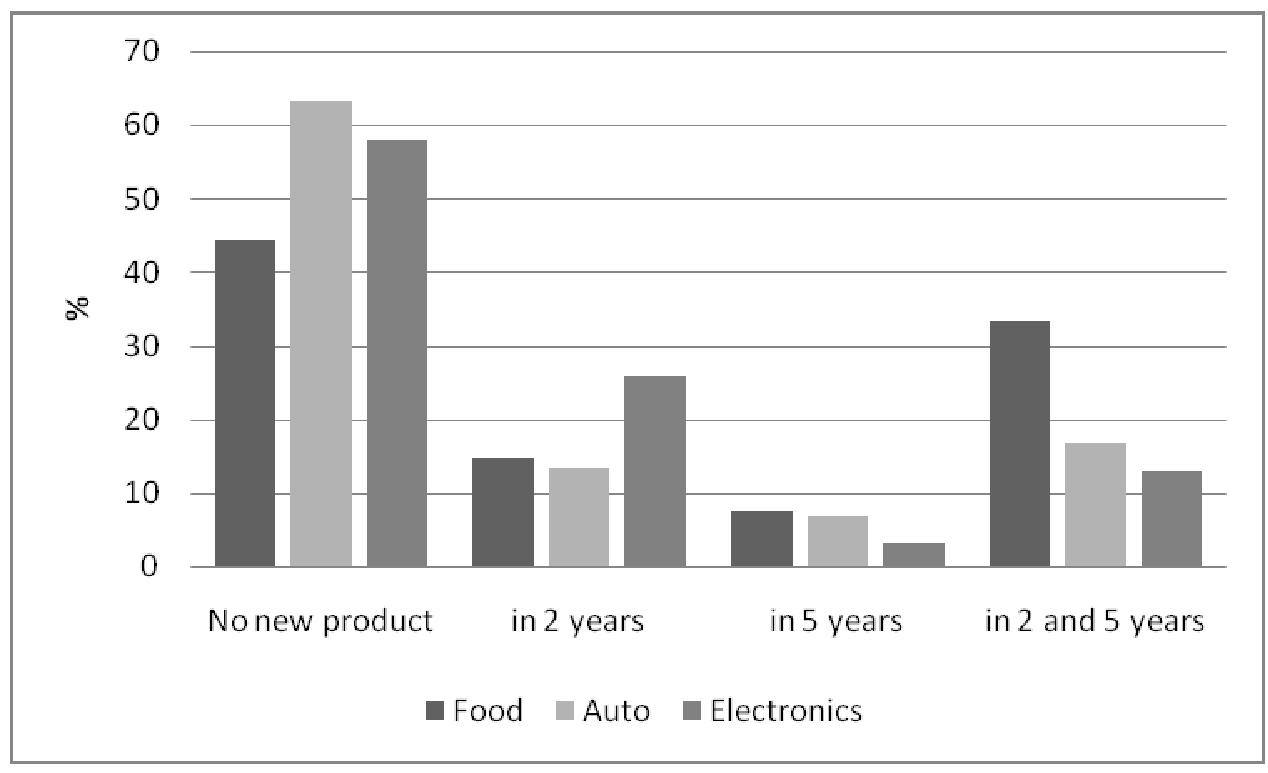

Source: TDRI 2009 
Figure 0.5: Sources of Product Designs

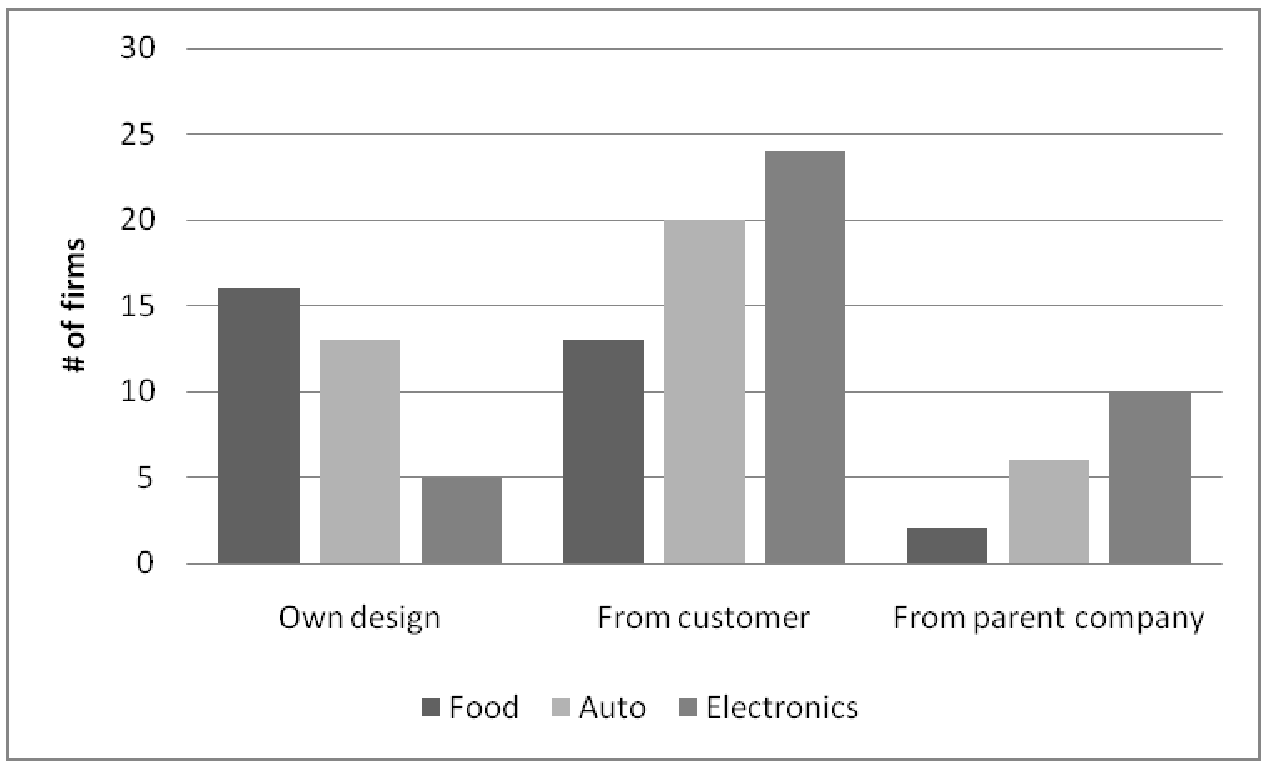

Source: TDRI 2009

Figure 0.6: Source of designs by ownership

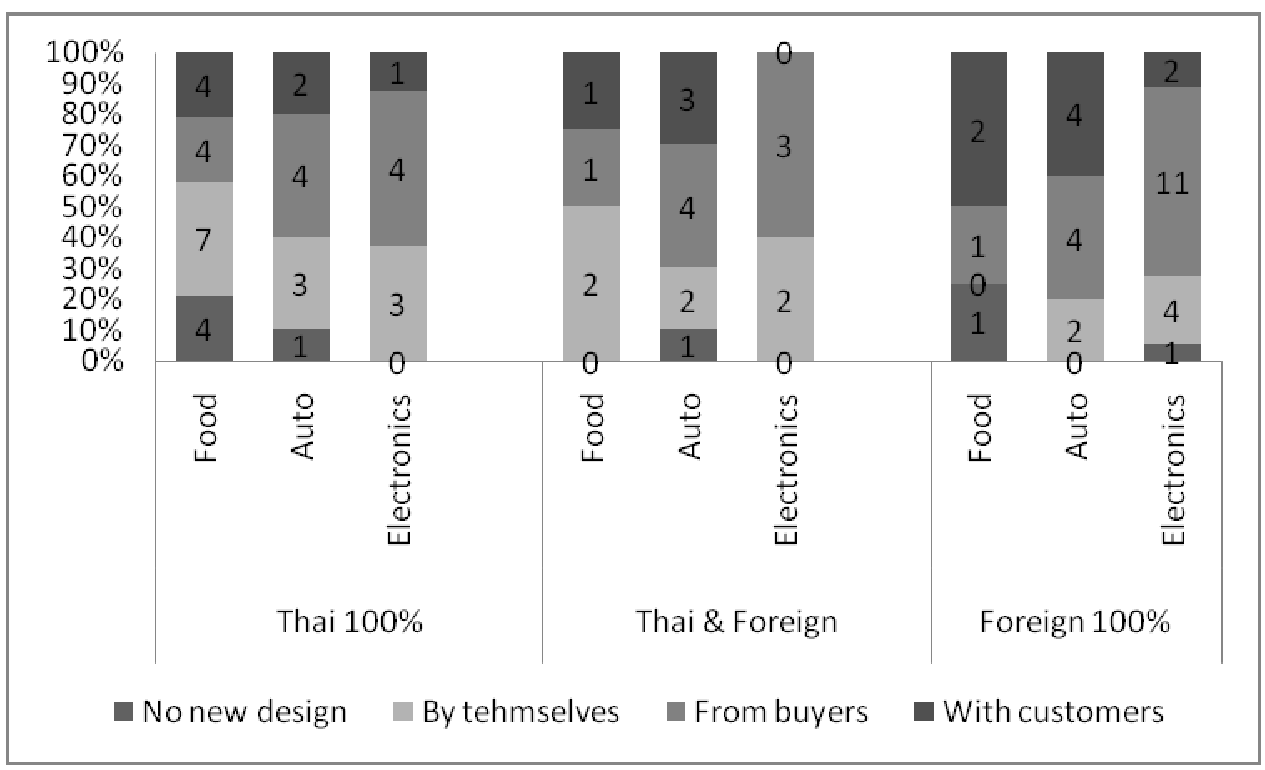

Source: TDRI 2009

The fewness of linkages with local firms and the wide dispersal of firms within and outside of the industrial parks have limited technological spillovers which tend to attenuate as the distance from a source such as an MNC production facility, increases. As the TDRI survey results show, few firms engage as yet in the co-creation, design and development of products with suppliers (see Figure 0.7). The MNCs and their 
subsidiaries rely on their own research and on R\&D conducted by facilities in their home countries. This is reflected in a large share of royalty payments to GDP in Thailand relative to other East Asian economies. ${ }^{47}$ They can work with buyers but rarely with suppliers across different ownership types (see Figure 0.9). The sparseness of technology spillovers has a dampening effect on the clustering impulse. Local firms have to struggle to upgrade and to find pathways to diversification. An essential dynamic which arises from the active collaboration among firms to design and refine products or processes and to develop new ones, and which also derives from a multiplicity of buyer-supplier relationships, is still weak or missing entirely.

Figure 0.7: Responses by firms on the questions, "Has your company ever designed or upgraded products with customers or suppliers?”

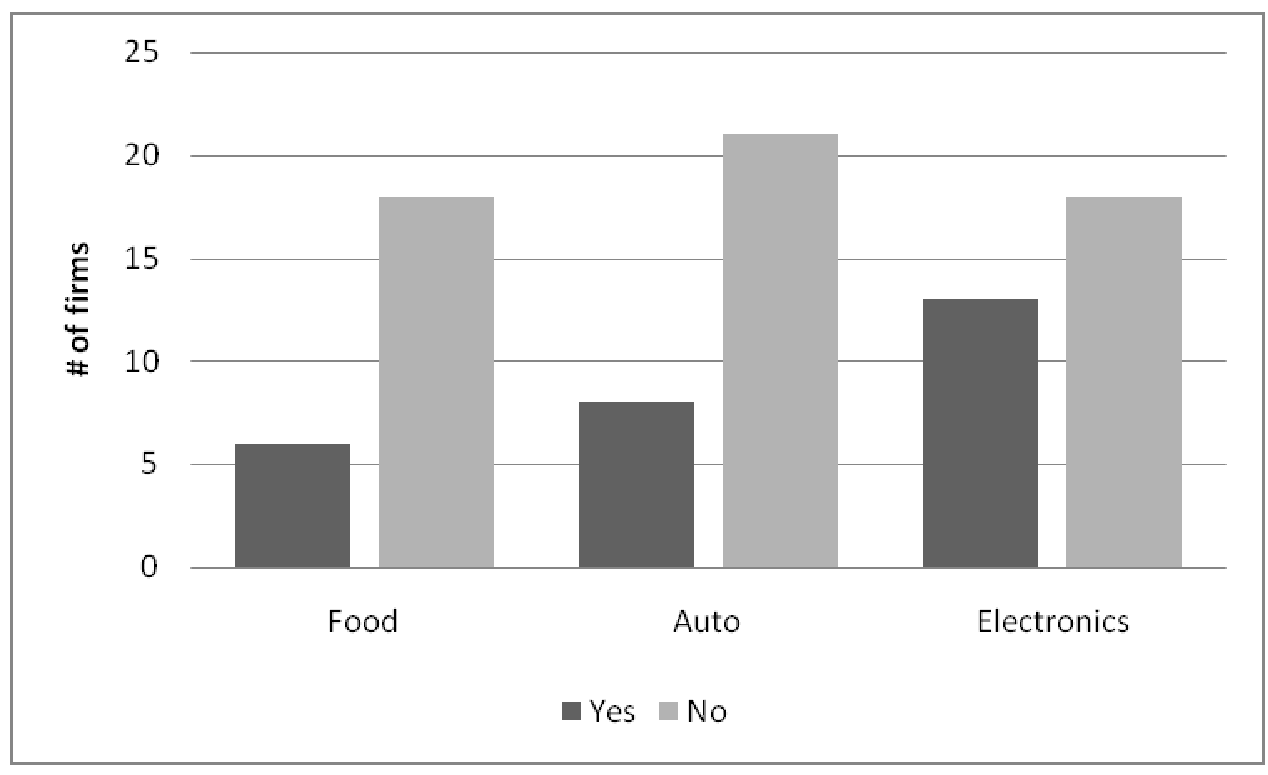

Source: TDRI 2009

\footnotetext{
${ }^{47}$ The share of royalty payments to GDP is the highest in Singapore at around 5-6\% during the first decade of the $21^{\text {st }}$ century.
} 
Figure 0.8: Royalty payments as a share of GDP

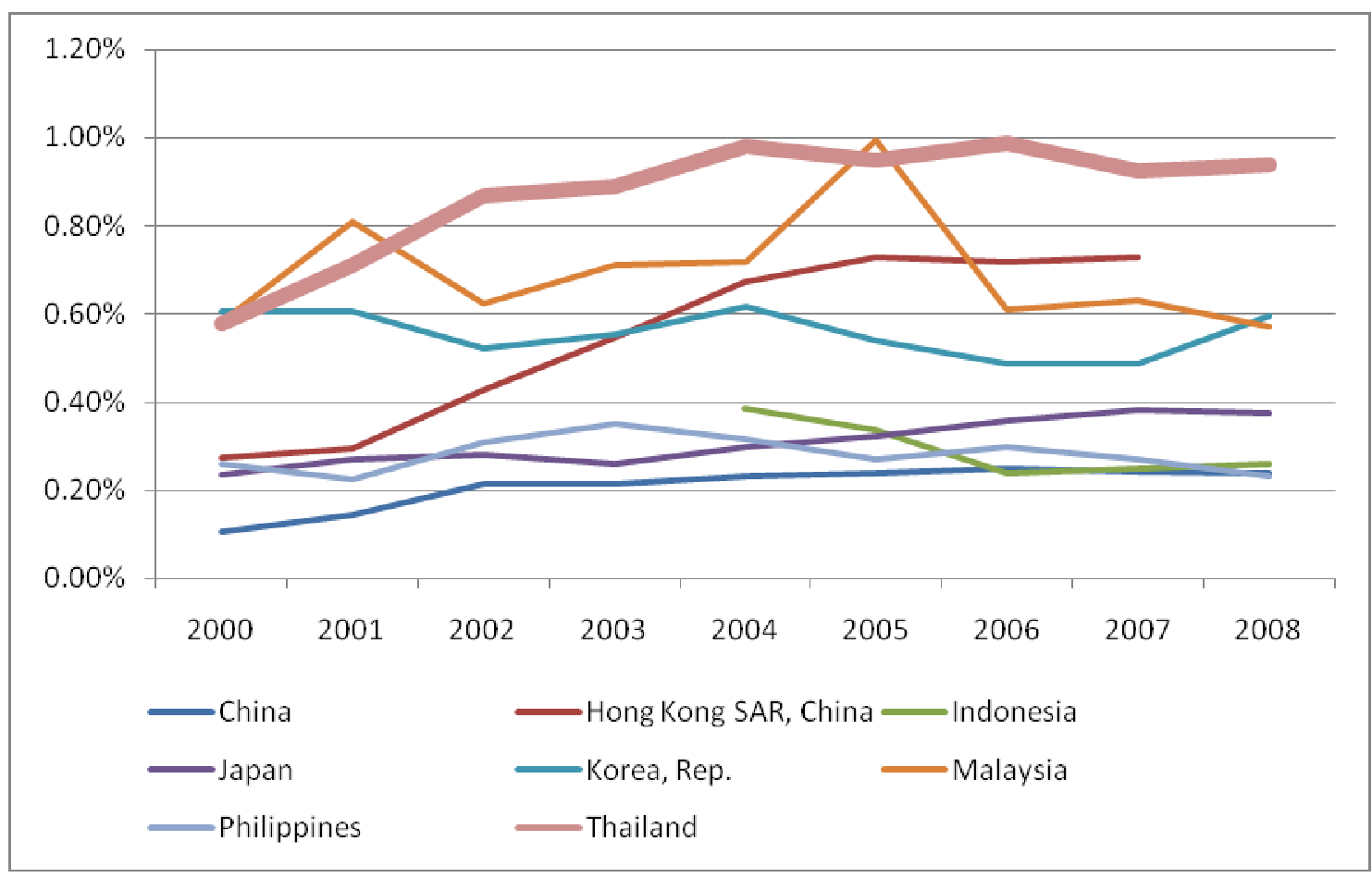

Source: World Development Indicators

Figure 0.9: Collaboration with customers and/or suppliers by ownership

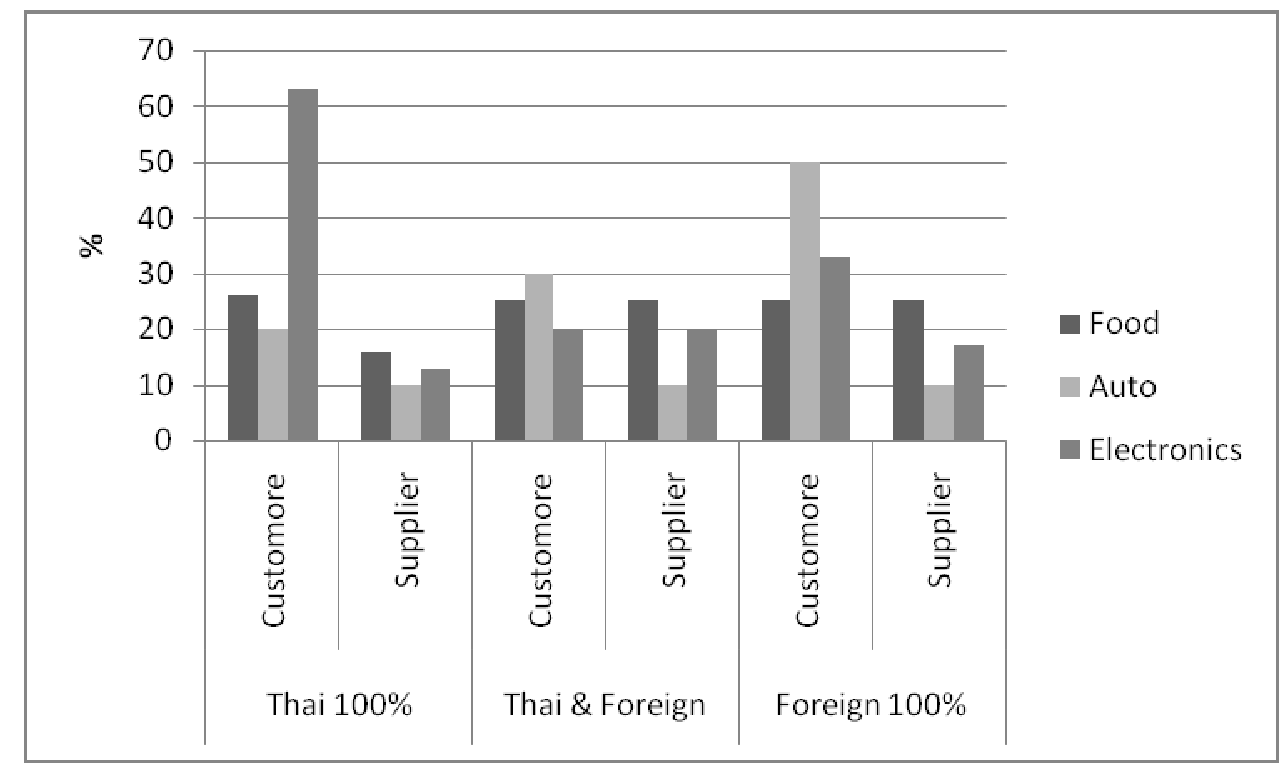

Source: TDRI 2009

Such an outcome was certainly not inevitable although under the circumstances and given the experience elsewhere in the region, not unexpected. A proactive stance by local firms to develop technologies or products and build relationships could have served to raise the 
density of clusters but this is an uphill task if the anchor MNCs are passive or worse unreceptive. As the survey results and other information show, three factors have made it harder for local firms to seek and grasp the (limited) opportunities which could arise from clustering at the current level of Thailand's development.

First, as noted above, technological upgrading and product development which could serve as the springboard for relationships with MNCs and the emergence of dynamic clusters in industries with clustering tendencies, are hamstrung by the low quality of the human capital and the level of entrepreneurship. Second, few domestic firms have displayed a readiness to invest in a steady enhancement of the manufacturing capabilities and in R\&D. In fact, R\&D in Thailand has remained unusually low - and MNCs continue to conduct most of their R\&D elsewhere. ${ }^{48}$

Third the survey reinforces other qualitative evidence pointing to few linkages between firms and universities. In 1999-2003, firms did not regard universities were an important source of technical information (see Table 0.6). This assessment did not change in the survey conducted in 2008. Universities are low on the scale of sources for technology and, in general firms do not engage in research or product development with academic researchers (see Table 0.7). ${ }^{49}$

\footnotetext{
${ }^{48}$ Although Toyota established the Toyota Technical Center Asia Pacific (TTC-AP) near Bangkok in 2005 to conduct development work on upper car bodies and specifications for Asian markets based on the platform and base models developed in Japan (JETRO 2005). TTC-AP later merged with Toyota Motor Asia Pacific Co. to establish Toyota Motor Asia Pacific engineering and Manufacturing Co. in April 2007 to support procurement of all Toyota plants in Asia-Pacific with an aim to increase local procurements (Toyota Motor Corporation 2009, p. 36).

${ }^{49}$ See also similar findings reported in World Bank (2008).
} 
Table 0.6: Sources of information and knowledge: 1999-2003

(0- not know, 1-not important, 5- very important)

\begin{tabular}{|c|c|c|c|c|c|c|}
\hline \multirow{2}{*}{ Source of Information } & \multicolumn{2}{|c|}{1999} & \multicolumn{2}{|c|}{2001} & \multicolumn{2}{|c|}{2003} \\
\hline & $\begin{array}{l}\text { R\&D } \\
\text { Firms }\end{array}$ & $\begin{array}{c}\text { Inno } \\
\text { Firms }\end{array}$ & $\begin{array}{l}\text { R\&D } \\
\text { firms }\end{array}$ & $\begin{array}{c}\text { Inno } \\
\text { Firms }\end{array}$ & $\begin{array}{l}\text { R\&D } \\
\text { Firms }\end{array}$ & $\begin{array}{l}\text { Inno } \\
\text { Firms }\end{array}$ \\
\hline Sources within the enterprise & 3.33 & 2.71 & 4.27 & 4.08 & 2.55 & 3.66 \\
\hline Parent/associate companies & 2.51 & 2.11 & 3.38 & 3.22 & 1.75 & 2.68 \\
\hline Clients & 3.40 & 2.91 & 4.08 & 3.73 & 2.48 & 3.76 \\
\hline Locally-owned suppliers & 2.58 & 2.18 & 3.39 & 3.05 & 2.00 & 2.97 \\
\hline Foreign-owned suppliers & 2.69 & 2.15 & 3.10 & 3.05 & 1.92 & 2.75 \\
\hline $\begin{array}{l}\text { Universities or higher education } \\
\text { institutes }\end{array}$ & 1.99 & 1.64 & 2.46 & 2.13 & 1.56 & 2.03 \\
\hline \multirow{2}{*}{$\begin{array}{l}\text { Government or private non- } \\
\text { profit research institutes }\end{array}$} & \multirow[t]{2}{*}{1.92} & \multirow[t]{2}{*}{1.63} & \multirow[t]{2}{*}{2.14} & \multirow[t]{2}{*}{1.95} & $1.51 *$ & $2.08^{*}$ \\
\hline & & & & & $1.05^{* *}$ & $1.59 * *$ \\
\hline Business service providers & 1.65 & 1.54 & 2.18 & 1.95 & 1.20 & 1.79 \\
\hline Technical service providers & 1.97 & 1.80 & 2.59 & 2.39 & 1.44 & 2.24 \\
\hline Competitors & 2.48 & 2.22 & 2.71 & 2.59 & 1.83 & 2.84 \\
\hline Patent disclosures & 1.44 & 1.39 & 2.17 & 2.07 & 1.26 & 1.75 \\
\hline Fairs and exhibitions & 2.40 & 2.11 & 3.12 & 3.10 & 2.00 & 2.85 \\
\hline $\begin{array}{l}\text { Professional conference \& } \\
\text { meeting }\end{array}$ & 2.47 & 2.09 & 3.16 & 2.68 & 1.88 & 2.70 \\
\hline Specialist literature & 2.73 & 2.23 & 3.25 & 2.73 & 1.92 & 2.69 \\
\hline Internet & 2.42 & 2.04 & 3.54 & 3.45 & 2.32 & 3.34 \\
\hline
\end{tabular}

Remark: *Public research institutes

**Private non-profit

Source: Doner and others (2010: 34) 
Table 0.7: Sources of information and technology

\begin{tabular}{lcccccc}
\multirow{2}{*}{ Sources of information } & \multicolumn{2}{c}{ Food } & \multicolumn{2}{c}{ Automobile } & \multicolumn{2}{c}{ Electronics } \\
& No. & $\%$ & No. & $\%$ & No. & $\%$ \\
\hline Product fair/ exhibition & 8 & 17.8 & 2 & 3.6 & 1 & 1.9 \\
Own company (Thai) & 7 & 15.6 & 4 & 7.3 & 6 & 11.5 \\
Suppliers & 6 & 13.3 & 4 & 7.3 & 5 & 9.6 \\
Website & 6 & 13.3 & 2 & 3.6 & 2 & 3.8 \\
Customers' firms & 4 & 8.9 & 12 & 21.8 & 14 & 26.9 \\
Parent company (foreign) & 3 & 6.7 & 15 & 27.3 & 12 & 23.1 \\
Conference with other firms & 2 & 4.4 & 1 & 1.8 & 0 & 0.0 \\
Machinery & 2 & 4.4 & 2 & 3.6 & 1 & 1.9 \\
University & 2 & 4.4 & 1 & 1.8 & 3 & 5.8 \\
Consult/visit/ traning inside or outside the & & & & & & \\
country & 0 & 0.0 & 3 & 5.5 & 3 & 5.8 \\
Others & 5 & 11.1 & 9 & 16.4 & 5 & 9.6 \\
Total & 45 & 100.0 & 55 & 100.0 & 52 & 100.0 \\
\hline Source
\end{tabular}

Source: TDRI 2009

The relative ranking of importance that firms attach to the collaborators have varied little between product and process innovation. Customers/buyers have been ranked the highest consistently, followed by suppliers (domestic and foreign) (see Figure 0.10)., Figure 0.11 and Figure 0.12). But attitudes are changing as competition intensifies and forces firms to confront technological challenges. Firms in food processing (30\%) and auto parts $(20 \%)$ industries have begun interacting more with universities in the past five years, but those in electronics are less likely to engage with universities (see Figure 0.14). Across industries, firms in the food processing industry collaborate the most with tertiary level institutions followed by autos (see Figure 0.13 ). ${ }^{50}$ Wholly Thai owned firms have increased collaboration with universities and research institutes in the last five years especially those in food processing (see Figure 0.15 and Figure 0.16 ). These figures suggest that firms in subsectors dominated by MNCs maintain fewer contacts with local universities and research institutes, because MNCs rely more on technology developed elsewhere and they are the principal sources of technology for suppliers.

\footnotetext{
${ }^{50}$ One such successful interaction between the shrimp industry and universities is described in Brimble and Doner (2007).
} 
Figure 0.10: External Collaboration for R\&D Activities for 1999-2003

\section{(0-not know, 1-not at all, 5-very intensely)}

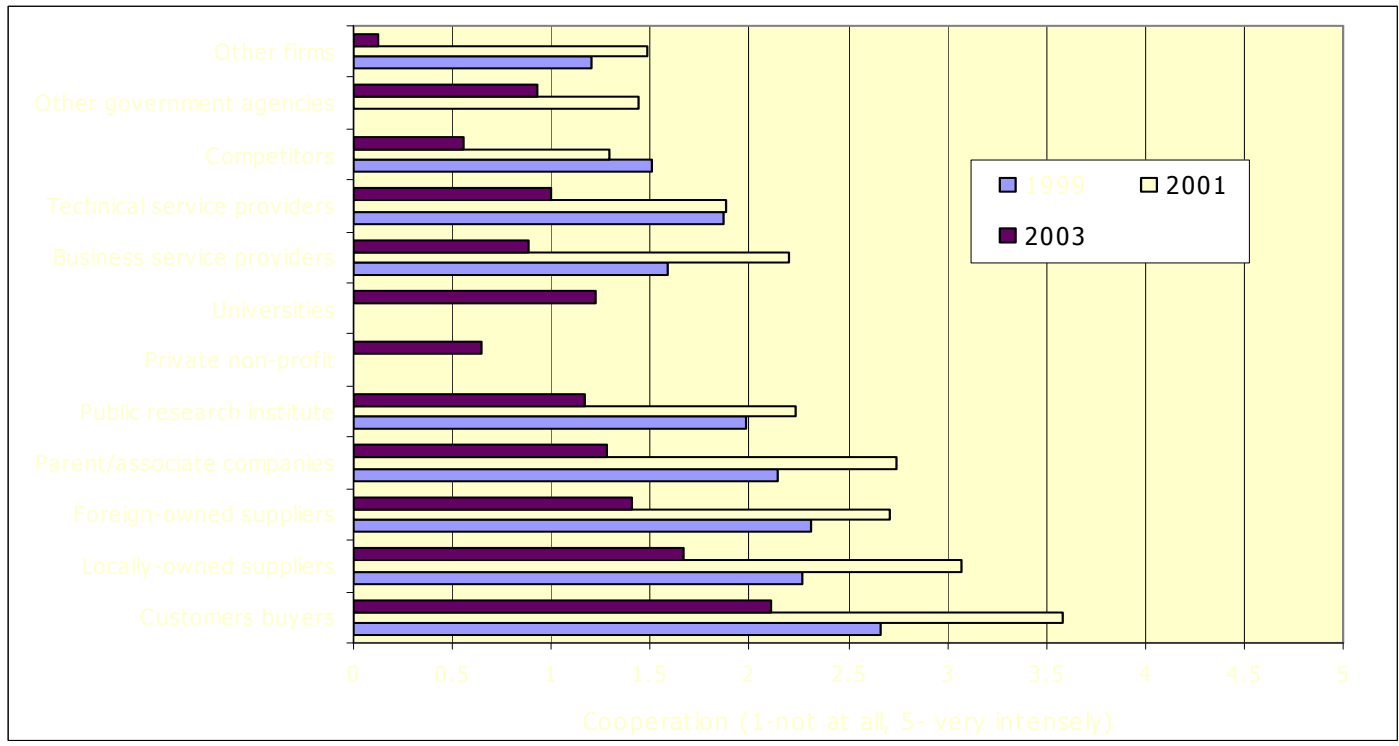

Source: Doner and others (2010: 35)

Remark: In the years 1999 and 2001, research institutes and universities are in the same category while public research institutes are separated from universities in the year 2003.

Figure 0.11: External Collaboration for Product Innovation for Year 1999- 2003

\section{(0-not know, 1-not at all, 5-very intensely)}

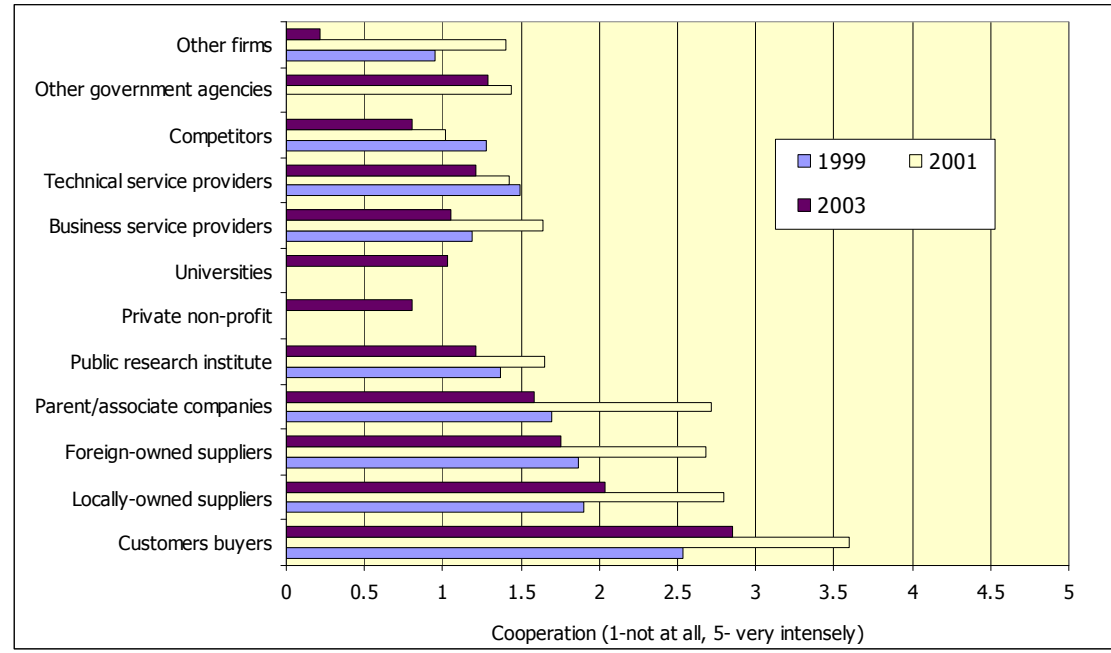

Source: Doner and others (2010: 36) 
Figure 0.12: External Collaboration for Process Innovation for Year 1999- 2003

(0-not know, 1-not at all, 5-very intensely)

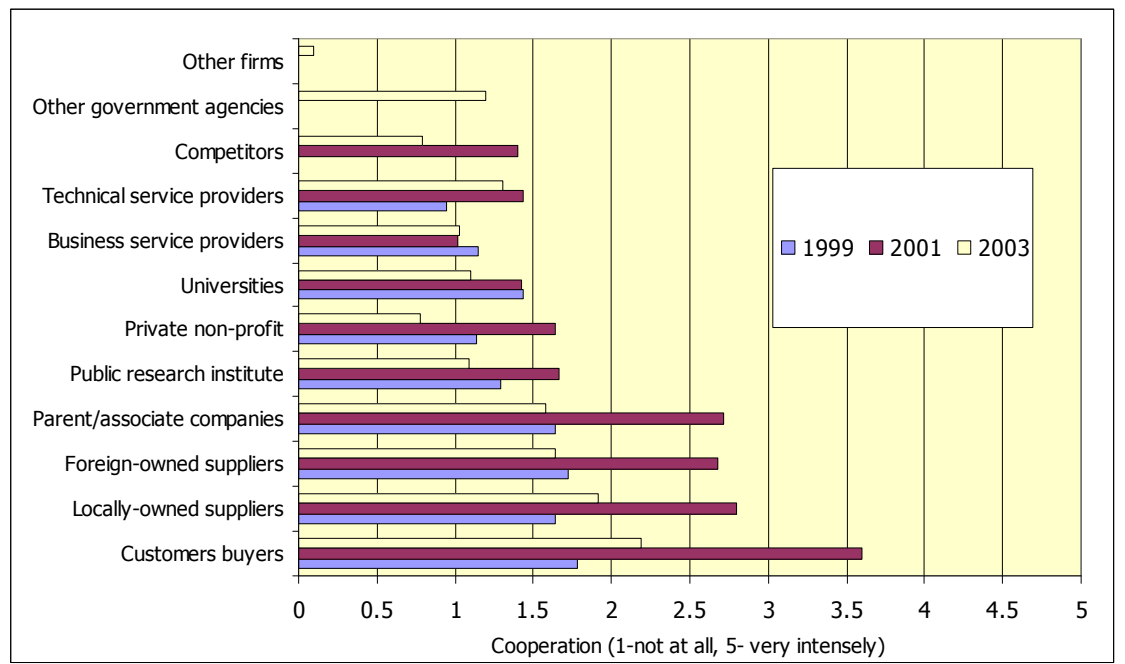

Source: Doner and others (2010: 36)

Figure 0.13: Share of firms seeking technical assistance or research support

from universities and research institutes

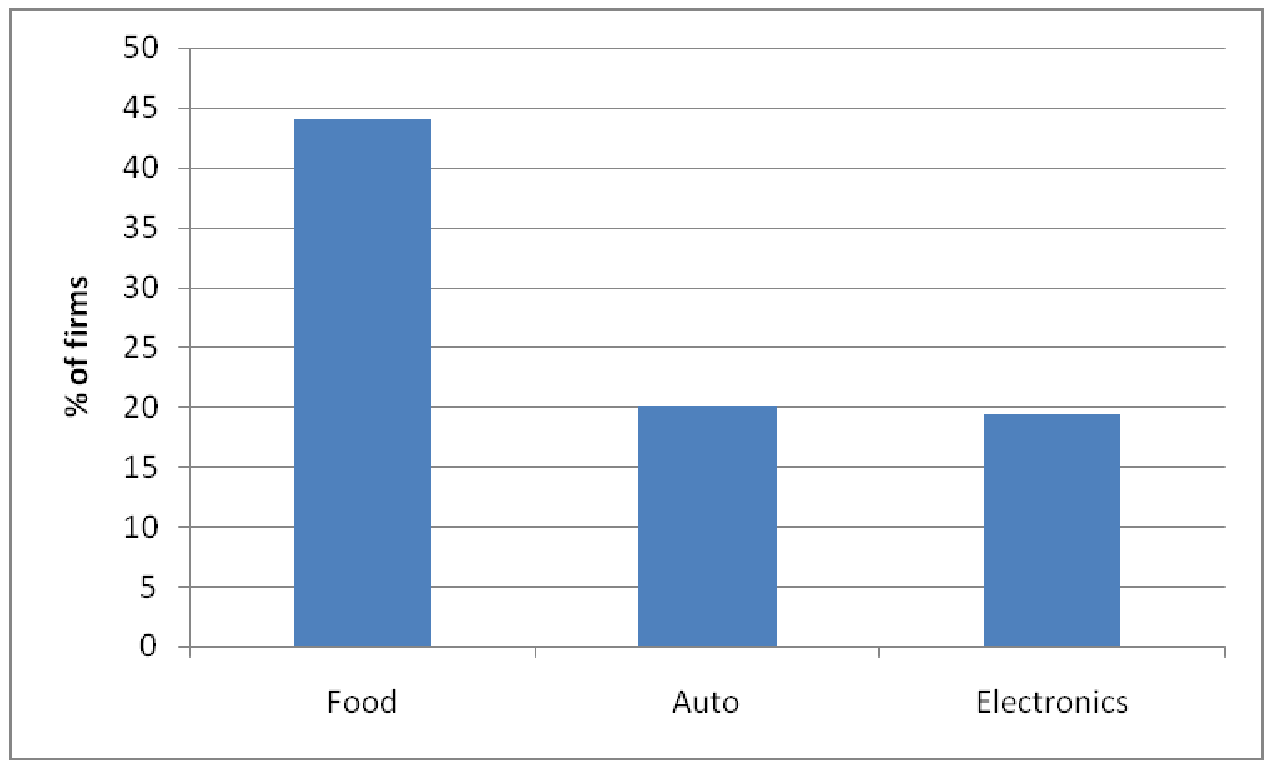

Source: TDRI 2009 
Figure 0.14: Share of firms that indicated an increase in collaboration with universities and research institutes in the past five years

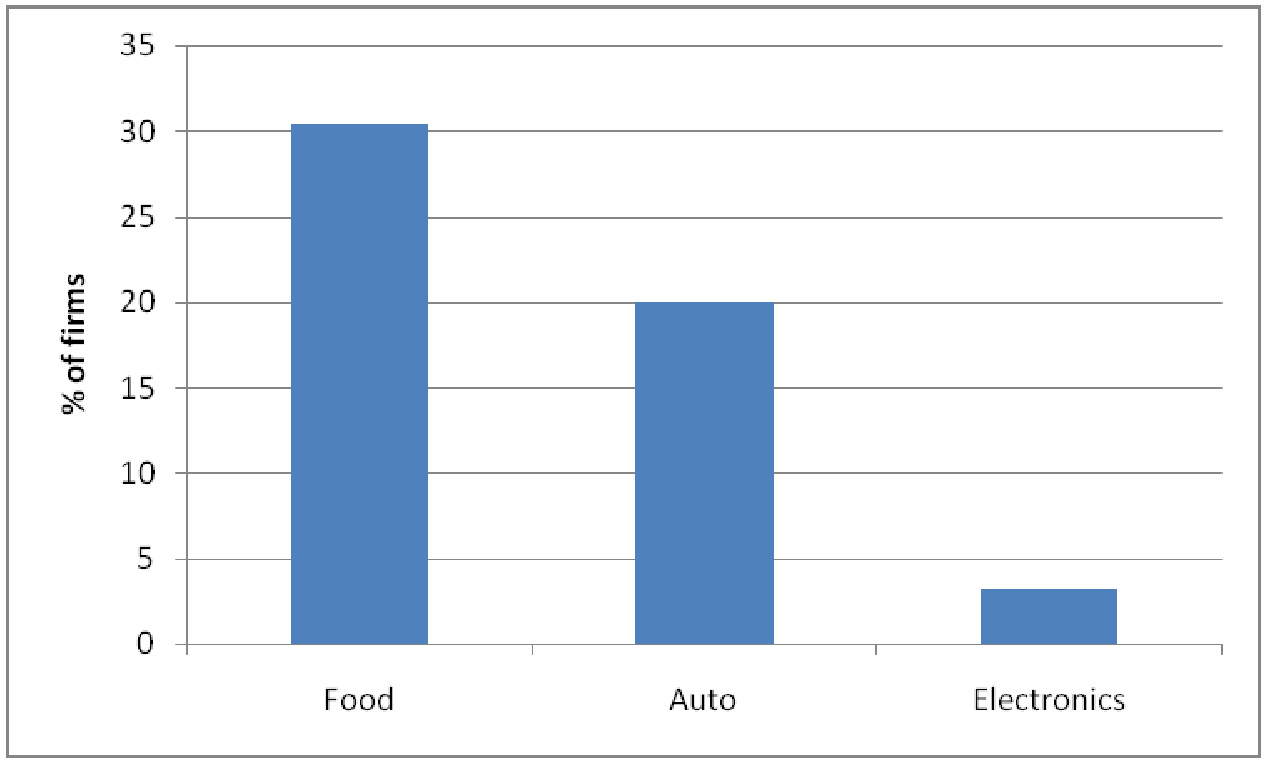

Source: TDRI 2009

Figure 0.15: Firms receiving technical assistance from universities or research institutes

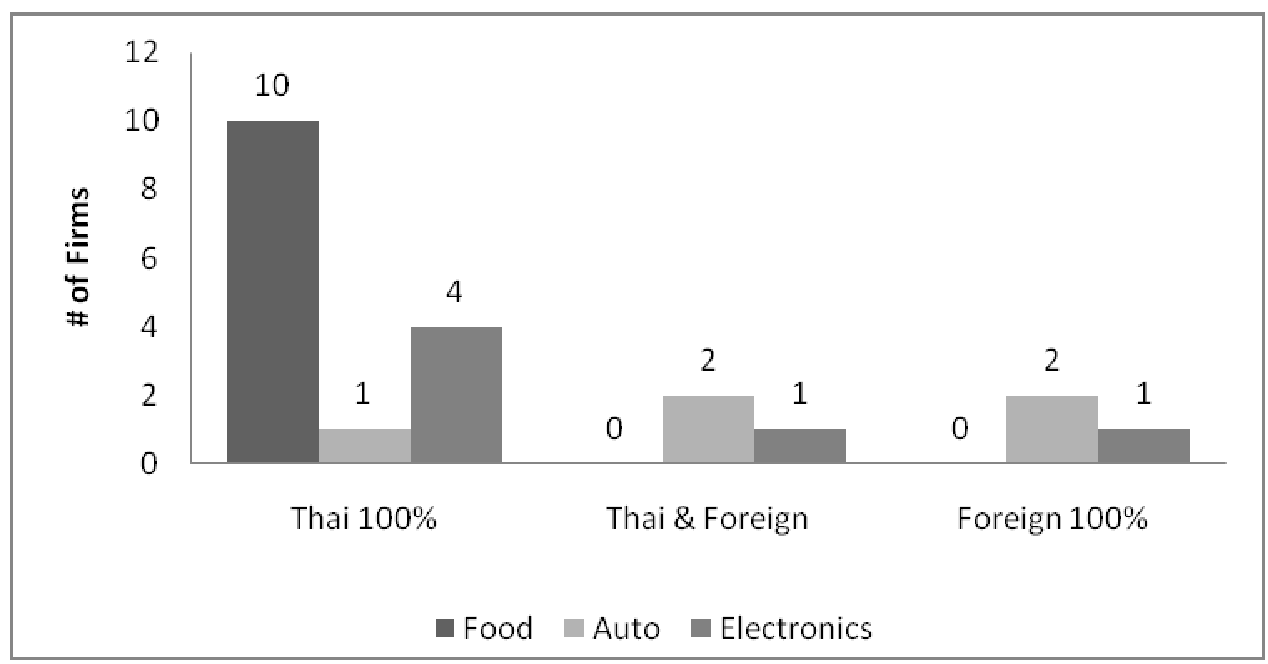

Source: TDRI 2009 


\section{Figure 0.16: Number of firms that increased collaboration} with universities or research institutes

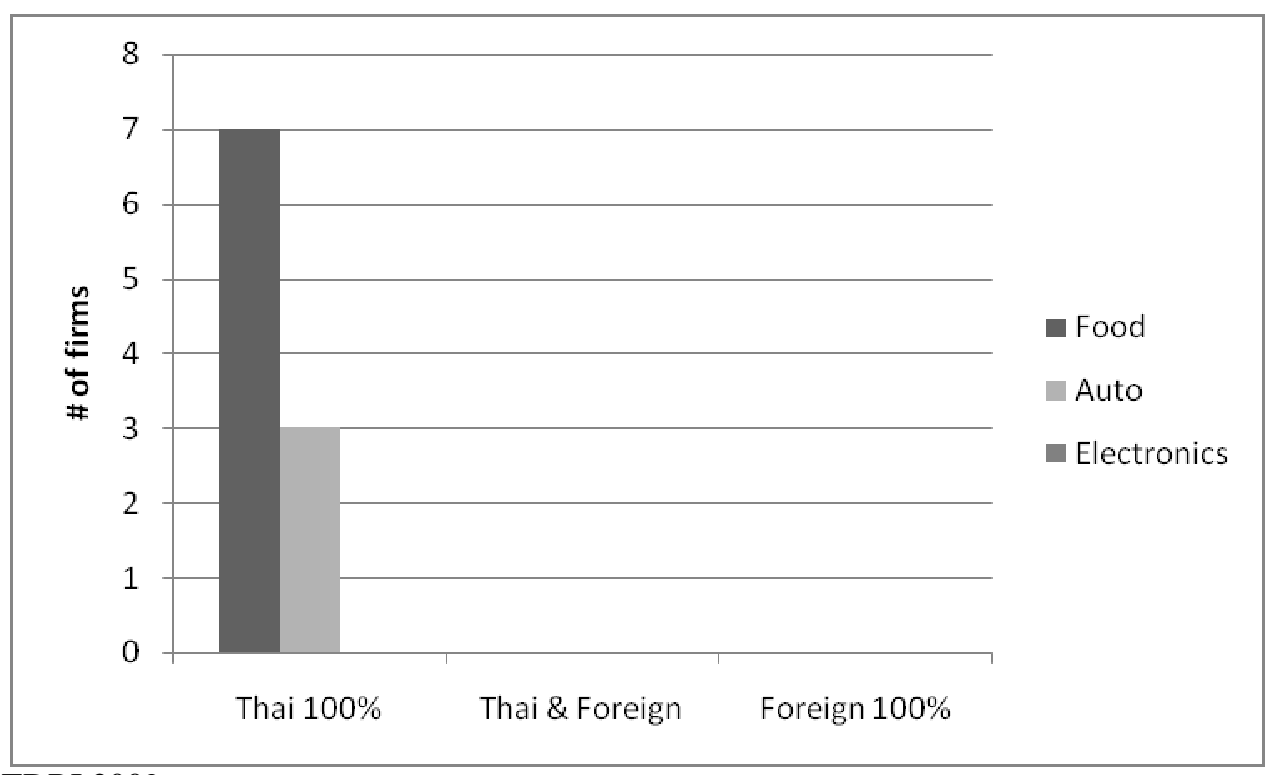

Source: TDRI 2009

University-industry linkages are no panacea but they can serve as catalysts. But a strengthening requires systematic collaborative effort to remedy what firms see as the shortcomings of university graduates through a redesigning of programs, a reform of the curricula, revising of textbooks, investment in the latest lab equipment and an emphasis on practical skills. ${ }^{51}$ It is the persistent weakness in the quality of the universities in Thailand, especially when it comes to R\&D capacity, and the location of the leading institutions in core urban area has made it difficult for universities to serve as nuclei for a cluster.

\section{$X$. The role of business services in cluster formation}

The emergence of clusters can be assisted by the presence of services providers. Indeed the presence of such providers is a basis for urbanization economies and the diversification possibilities inherent in large urban regions.

Most producer services such as finance, accounting, research, advertising, marketing, legal, IT and insurance are located in the core urban area of Bangkok (see Table 0.8). In

\footnotetext{
${ }^{51}$ Although, the Thai Garment Manufacturers Association and Thai Garment Development Fund worked with universities to create special MBA programs. However, the results so far are unsatisfactory.

Thailand's supply of operators and engineers was still weak by the end of 2006, especially compared to its competitors in the region (Doner 2009).
} 
particular, market research services are only available in Bangkok. Similarly, a majority of other high value-added services such as legal, accounting, architecture and engineering firms are located in Bangkok. ${ }^{52}$ Real estate, logistics and human resource management services are somewhat more dispersed and frequently closer to production facilities in the vicinity of the Eastern Seaboard and industrial estates.

Table 0.8: Proportion of services purchased by factories, sorted by location

\begin{tabular}{|c|c|c|c|c|c|}
\hline \multirow[b]{3}{*}{ Types of services } & \multicolumn{5}{|c|}{ Percentage $(\%)$} \\
\hline & \multirow{2}{*}{$\begin{array}{c}\text { Same } \\
\text { district }\end{array}$} & \multirow{2}{*}{$\begin{array}{c}\text { Same } \\
\text { province }\end{array}$} & \multicolumn{2}{|c|}{ Other provinces } & \multirow[b]{2}{*}{ Total } \\
\hline & & & Bangkok & Other & \\
\hline Commercial real estate & 38.89 & 38.89 & 11.11 & 11.11 & 100.0 \\
\hline Computer & 15.22 & 34.78 & 32.61 & 17.39 & 100.0 \\
\hline Research and development & 9.09 & 18.18 & 54.55 & 18.18 & 100.0 \\
\hline Legal & 2.08 & 18.75 & 77.08 & 2.08 & 100.0 \\
\hline Accounting & 4.05 & 10.81 & 85.14 & 0.00 & 100.0 \\
\hline Market research & 0.00 & 0.00 & 100.00 & 0.00 & 100.0 \\
\hline Architecture and engineering & 3.23 & 16.13 & 74.19 & 6.45 & 100.0 \\
\hline Advertising & 12.5 & 0.00 & 87.5 & 0.00 & 100.0 \\
\hline Head hunter & 11.76 & 14.71 & 67.65 & 5.88 & 100.0 \\
\hline Logistic & 10.00 & 18.57 & 60.00 & 11.43 & 100.0 \\
\hline
\end{tabular}

Source: TDRI 2009

The survey results suggest that the industrial sector is by and large adequately serviced even though most providers are at a distance from the production facilities. The level of satisfaction derives from two factors: (a) the downtown head offices of most of the larger firms near the services providers (see

\footnotetext{
${ }^{52}$ Services firms do not receive any incentives from BOI. As a result, many of them do not intend to expand outside of Bangkok.
} 
Table 0.9); ${ }^{53}$ and (b) the sufficiency of phone and internet based communication (see Table 0.10). ${ }^{54}$ Firms utilize these services as needs rise (see

\footnotetext{
${ }^{53}$ Other reasons for locating within Bangkok are the distance between the office and executives' residences, proximity to government agencies, and the availability of Sky trains and expressways.

${ }^{54}$ Most firms do not consider face-to-face communication to be crucial. Instead, the telephone was the most commonly used method to conduct businesses.
} 
Table 0.11). Exceptions are accounting which is often used on an annual cycle (to prepare for the end of fiscal year) and logistics which are used daily most often. 
Table 0.9: Factors to consider when locating company offices

\begin{tabular}{lcc}
\hline Factors & No. of answers & $\%$ \\
\hline Near business centre & 5 & 12.5 \\
Convenient for customer & 5 & 12.5 \\
Price & 5 & 12.5 \\
Land size & 5 & 12.5 \\
Near the executive's residence & 4 & 10.0 \\
Near government office & 3 & 7.5 \\
Near BTS/MRT & 3 & 7.5 \\
Near expressway & 3 & 7.5 \\
Good image & 2 & 5.0 \\
Convenient for staff & 1 & 2.5 \\
Convenient to take intern & 1 & 2.5 \\
Near Japanese company & 1 & 2.5 \\
Good security system & 1 & 2.5 \\
Near mother company & 1 & 2.5 \\
Total & 40 & 100.0 \\
\hline
\end{tabular}

Source: TDRI 2009

Table 0.10: Proportions of communication channels between factories and business services firms

\begin{tabular}{lccccc}
\hline Types of service & $\begin{array}{c}\text { Face to } \\
\text { face }\end{array}$ & Telephone & Fax & E-mail & B2B \\
\hline Commercial real estate & 22.6 & 61.3 & 9.7 & 6.5 & 0.0 \\
& 39.0 & 42.9 & 7.8 & 10.4 & 0.0 \\
Computer & 28.0 & 36.0 & 20.0 & 16.0 & 0.0 \\
Research and development & 23.2 & 55.1 & 7.2 & 13.0 & 1.4 \\
Legal & 37.3 & 41.3 & 8.0 & 12.7 & 0.7 \\
Accounting & 31.3 & 43.8 & 12.5 & 12.5 & 0.0 \\
Marketing research & 33.3 & 47.6 & 9.5 & 9.5 & 0.0 \\
Architecture and engineering & 24.2 & 45.5 & 15.2 & 15.2 & 0.0 \\
Advertising & 19.2 & 51.9 & 7.7 & 17.3 & 3.8 \\
Head hunter & 18.3 & 51.1 & 13.0 & 17.6 & 0.0 \\
Logistics & & & & & \\
\hline
\end{tabular}

Source: TDRI 2009 
Table 0.11: Frequency of use of business services

\begin{tabular}{lccccc}
\hline Types of business service & Daily & Weekly & Monthly & Yearly & $\begin{array}{c}\text { When } \\
\text { needed }\end{array}$ \\
\hline Commercial real estate & 10.5 & 15.8 & 15.8 & 5.3 & 52.6 \\
Computer & 0.0 & 2.2 & 19.6 & 8.7 & 69.6 \\
Research and development & 0.0 & 0.0 & 15.4 & 0.0 & 84.6 \\
Legal & 0.0 & 0.0 & 6.8 & 11.4 & 81.8 \\
Accounting & 1.4 & 4.1 & 41.9 & 43.2 & 9.5 \\
Market research & 0.0 & 0.0 & 0.0 & 0.0 & 100.0 \\
Architecture and engineering & 0.0 & 3.6 & 3.6 & 3.6 & 89.3 \\
Advertising & 0.0 & 0.0 & 36.4 & 4.5 & 59.1 \\
Head hunter & 0.0 & 2.9 & 5.9 & 11.8 & 79.4 \\
Logistic & 38.6 & 18.6 & 27.1 & 1.4 & 14.3 \\
\hline
\end{tabular}

Source: TDRI 2009

Table 0.12 lists the core services offered by 10 common business services and new services that they have begun offering in the last 5 years. An examination of these new products indicates that most represent a diversification of their existing activities, rather than the result of a strategy to improve the quality or design of services and to pursue innovation. In fact, most business services firms have registered their trademarks rather than innovation patents. The survey results also found that business services firms have not aggressively used IT to generate new knowledge and innovation that would upgrade their services qualities and improve their productivity as has been the case in the United States and in Japan for example (Jorgenson, Dale W. and Motohashi 2005, Jorgenson, Dale W. and Stiroh 2000, Jorgenson, Dale.W. 2001). The lack of innovation notwithstanding, between 1997 and 2007, all of the services industries in Table 0.8 increased their outputs. Among them, the fastest growing are computer, and research and development services. 


\section{Table 0.12: The core services and new services of each service sector during the last 2 and 5 years}

\begin{tabular}{lll}
\multicolumn{1}{c}{ Type of services } & \multicolumn{1}{c}{ Core services } & \\
\hline Commercial real-estate & -room lease & New services \\
Computer and related & -land lease & sell/lease warehouse and storage \\
& -data sorting & \\
R\&D & -IT system installation & Visual Private Network installation \\
& -develop new products & program designing \\
Legal & -business planning & \\
Accounting & legal consultancy & none \\
Market research & account inspection & none \\
Architectural and Engineering & market researching & none \\
& supervise construction & Engineering structural design \\
Advertisement & project & \\
& -advertising boards & -advertising design \\
& -advertising plan & -research and strategy in \\
& -creative advertisement & advertisement \\
Labor recruitment & -other media channels for & \\
advertisement & \\
& labor recruitment & Online payment \\
& Transport goods & - Warehousing \\
& & - consultancy on production process \\
& & development \\
\hline
\end{tabular}

Source: TDRI 2009

The low rates of innovation apparent from the responses to the survey give rise to doubts as to whether the concentration of services in the downtown areas has initiated the kind of upgrading associated with a dynamic cluster. There have been few new entrants to the business supporting services sectors in Bangkok, and even if there were, these new entries are in slightly different business lines, often complementing the existing firms (see Figure 0.17). 
Figure 0.17: The effects of new companies entering in the same locations

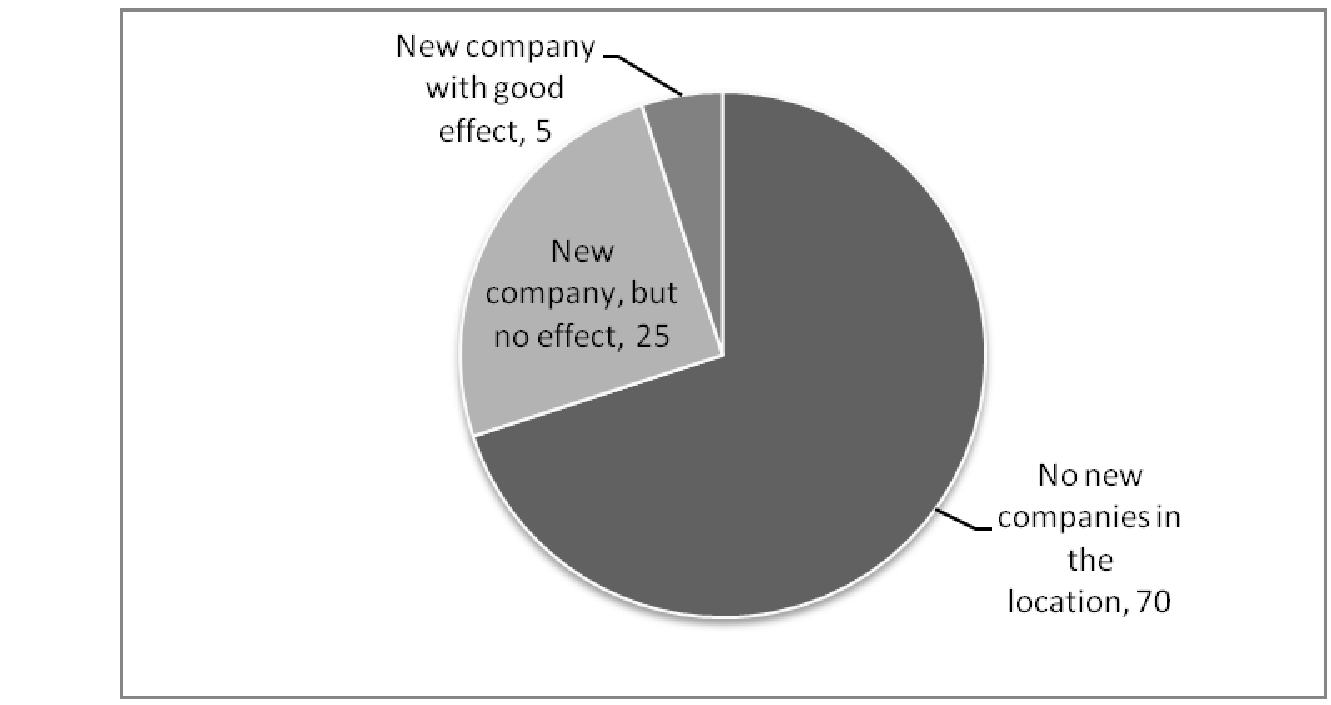

Source: TDRI 2009

It appears that the services industry is firmly anchoring manufacturing to the Bangkok region. The survey responses do not suggest however, that the consulting and R\&D services are at the stage when they can actively supply the ideas, the financing and the entrepreneurship to help industry diversify and move up the technological ladder.

The problem with services as with manufacturing lies in the quality of the labor force, especially the low quality of new graduates. Survey respondents complained that new graduates had weaker grounding in theory and their practical knowledge was poorer. Firms are of the view that work ethics and readiness to put in long hours had also diminished. In contrast, the quality of management staff in general was quite satisfactory, although specific skills especially in legal services are scarce.

The paucity of research talent in Bangkok is evident from the high turnover of researchers - the highest among all services providers. Currently the demand for researchers is outstripping the supply. Moreover, recent Thai graduates often do not have the skills and creativity in delivering the service that the market demands.

Echoing the responses of the manufacturing firms, the services survey strongly suggests that the Thai educational system should be improved by incorporating more practical knowledge and hands on training to better prepare students for future employment.

Table 0.13: Use of Internet in the industry 


\begin{tabular}{cccc} 
Use of internet & Food & Automobile & Electronics \\
\hline Yes & 96.3 & 93.3 & 100 \\
No & 3.7 & 6.7 & 0 \\
\hline
\end{tabular}

Source: TDRI 2009

Recent research has underlined the contribution of the ICT infrastructure to urban productivity and innovativeness. By facilitating connectivity and collaboration, by enormously improving access to information and by providing platforms for innovation including hardware, software, services and networking, ICT can contribute to both clustering and to urbanization economies. The survey shows that almost all firms have internet access (see

Table 0.13) and use it for general communication, financial transactions and in dealing with product orders. But firms rarely use IT for business development like searching for information about raw material or new production methods, on new market opportunities, or for dealing with governmental agencies, is still rare (see

Table 0.14).

The majority of firms (84\%) feel that the IT infrastructure in the Bangkok region is adequate (see

Figure 0.18). ${ }^{55}$ Most services firms also thought that the quality of IT infrastructure was decent, especially those in legal services which used many types of IT and also had highest IT expenditure. Firms that were not satisfied with the quality of IT and wireless services complained that the internet speed in Thailand was too slow and connections unreliable. This is related to the low availability of fixed broadband connections in Thailand relative to other countries. While the number of internet users is comparable to those in China in 2008, the diffusion of fixed broadband connections is lower in Thailand (see Figure 0.19). However, they noted that high-speed Internet connections with greater reliability were available, but at a price they could not afford. For example, in service and price, ICT in Bangkok falls far short of what is available in Seoul, Tokyo and Singapore. Businesses in Bangkok are not significantly constrained, but by the same token, the IT services are failing to serve as enablers of innovation and of productivity. Half of the firms sampled had not introduced organizational and procedural changes so as to fully exploit the benefits of new ICT technology and slightly more than half felt that IT

${ }^{55}$ Thailand spends $6 \%$ of GDP in IT-related investment (Yilmaz 2009). 
did not reduce business costs. There is low hanging fruit here that many firms in Bangkok have not picked.

Table 0.14: Types of Internet usage in industrial factories

\begin{tabular}{lcc}
\hline Types of usage & No. of answers & $\%$ \\
\hline Internal communication & 36 & 19.9 \\
E-mail & 23 & 12.7 \\
Financial transaction & 21 & 11.6 \\
Information searching & 20 & 11.0 \\
Taking-receiving orders for products & 19 & 10.5 \\
Communication & 19 & 10.5 \\
General usage & 12 & 6.6 \\
Search for raw materials & 7 & 3.9 \\
Public relations through website & 7 & 3.9 \\
Search information of customers and/or supplier & 4 & 2.2 \\
Contact BOI & 3 & 1.7 \\
Search for legal data & 2 & 1.1 \\
Online product registration & 2 & 1.1 \\
Inform company status to mother company & 2 & 1.1 \\
Teleconference & 1 & 0.6 \\
Receiving complaints & 1 & 0.6 \\
Find labor & 1 & 0.6 \\
Contact customs & 1 & 0.6 \\
Total & 181 & 100 \\
\hline
\end{tabular}

Source: TDRI 2009

Figure 0.18: The cost and quality of the IT infrastructure that you use for business purpose

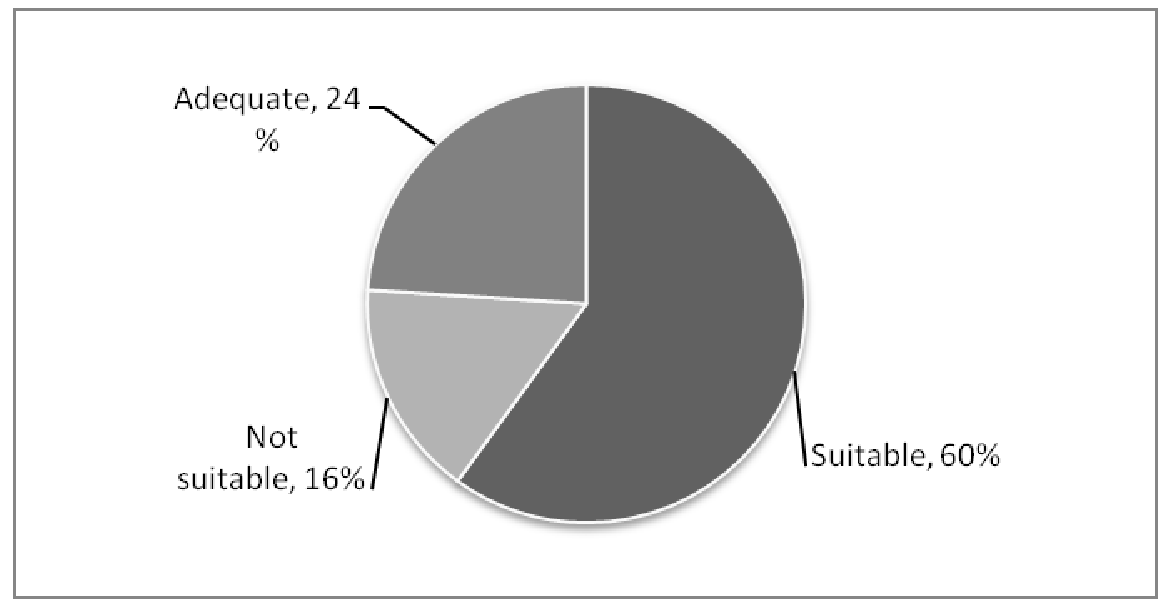

Source: TDRI 2009 
Figure 0.19: Internet services availability (per 100 people), 2008

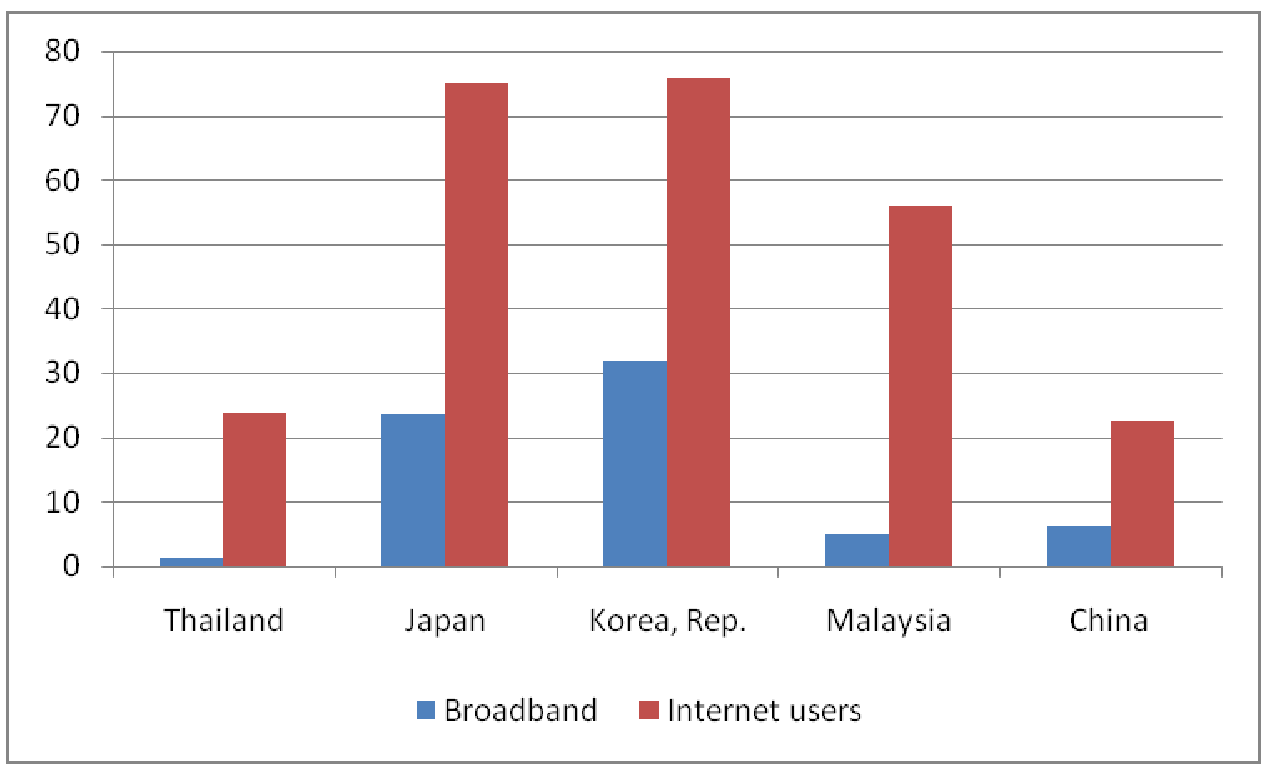

Source: World Development Indicators

Transport connectivity is another key ingredient of an urban system and given Bangkok's reputation for extreme traffic congestion, the responses to our survey were quite revealing.

Around $77 \%$ of industrial firms were satisfied with the cost, quality, and speed of such transport facilities. The firms that are dissatisfied -accounting for $23 \%$ of the overall samples- were mostly in food industry, with 11 food firms out of 27 or $41 \%$ of the total food firm samples. This was because food products are perishable and thus need to be delivered faster than those of automotive and electronics industries. Close to $90 \%$ of business services firms thought the cost, quality and speed of $\operatorname{transport}^{56}$ and communications with downtown Bangkok and/or ports and airports are adequate, thanks to the BTS and the metro system. The road links between production centers and the city and between production centers and ports and airports received a positive rating.

But respondents stressed that surface transport links figure prominently in location decisions because the distance from their factories to downtown Bangkok was a key consideration and that there is plenty of room for improvement which could further

\footnotetext{
${ }^{56}$ According to a recent report on Thailand's infrastructure, $96 \%$ of the roads in the country have a vehicle/capacity ratio of 0.5 which means that utilization is at the $50 \%$ level. Roads around Bangkok or leading to Laem Chabang Port are at a 0.8 level or greater (World Bank 2008a)
} 
integrate the urban region, reduce logistics costs and contribute to productivity. For example, expanding the BTS, adding a bus rapid transit system and developing the railway and road networks connecting Bangkok and outer provinces would significantly improve travel conditions, cut expenses and reduce the time wasted snarled in traffic. They would also make Bangkok a greener city.

Although transport services are deemed adequate, transportation costs in Thailand are much higher than those in other countries. The NESDB estimated the transportation costs to be $19 \%$ of GDP in 2002 in Thailand ${ }^{57}$ compared to $10 \%$ in the United States. High logistics costs can be traced back to the inefficiency in freight transport. ${ }^{58}$ The inefficiencies arises from "aged fleets of trucks with low load limits and low fuel efficiency, the low penetration of multi-modal logistics providers, limited capital for new investment by small firms, and limited use of Electronic Data Interchange for facilitating shipment and delivery and supply chain management" (World Bank 2008, p.23).

From all indications, Bangkok will remain the focus of business services in Thailand. $32 \%$ of service entrepreneurs commented that their future customers would still locate in Bangkok and 24\% in the connecting provinces like Pathumthani, Ayutthaya, Chonburi, Rayong, and Samut Prakarn. And few respondents thought that a move away from Bangkok was in the cards.

\footnotetext{
${ }^{57}$ These are comparable to those in China.

58 The main problem with external logistics arises from congestion at the Laem Chabang container port.
} 



\section{Findings and Policies: A Summing Up}

In response to the questions posed in the opening chapter of this study, our findings can be summarized as follows.

- The development of manufacturing and services in the Bangkok region is continuing with the entry of firms and the creation of new production units in each of the subsectors examined. ${ }^{59}$ Growth is likely to be slower than in the $1980 \mathrm{~s}$ and 1990s, how much slower will depend upon the recovery of the global market from the 2009 crisis and the sustainability of the growth thereafter, socio-political stability in Thailand, a revival of investment in productive activities and greater emphasis on productivity gains through technological advances and innovation by domestic firms. Bangkok's share of industrial production has slid downwards by a few percentage points as a result of increased activity in the provinces directly north of the city, but the change is a modest one and there is little reason to expect that industry will disperse widely across the country. In fact as we argue below, several key industrial and services activities are entering a stage in their development when concentration in the mega region will be more advantageous than it was in the recent past - as is the case in other parts of Asia.

- Bangkok's competitive advantage appears to be strengthening in auto manufacturing and the food processing industries and several services industries are also thriving, most notably publishing marketing and computer services. Others such as textiles, metal manufacturing and jewelry are demonstrating staying power, with only electronics seemingly giving ground. This jives with the emergence of Thailand as a hub for auto manufacturing in Southeast Asia and a focus of investment by MNCs as well as their component suppliers. Food processing is in line with Thailand's comparative advantage in agricultural products and fisheries, the international popularity of Thai food, and with the efforts to become a "kitchen of the world". The slowing growth of the electronics components industry is surprising but it may be associated with the migration of some manufacturing to China and Vietnam and with the shift to lower cost production platforms of the most price sensitive items to areas lying to the north of Bangkok. However, the appliances industry remains fairly robust and demand from this subsector and from the auto industry are fuelling the continuing growth of metal working firms. Bangkok's longstanding comparative advantage in

\footnotetext{
${ }^{59}$ This multiplication of firms that enriches the small firm ecosystem is a significant asset as pointed out by Rosenthal and Strange (2010).
} 
textiles and jewelry production accounts for the resilience of both industries and their rootedness in the core areas where they are close to domestic customers and to providers of design services as well as other services. The garments industry has dispersed to other parts of the urban region but as in many other cities including New York and Los Angeles - this activity manages to hang on, even when other types of producers move.

- The GIS and other data collectively present a picture of enduring industrial diversity that is being reinforced by the proliferation of services in the core area of Bangkok. Bangkok's competitive advantage as a regional logistics hub remains strong, however, maintaining this advantage and the city's attractions for tourists will be influenced by the restoring of social stability. The potential urbanization economies are significant and in fact could be growing. Furthermore, the movement of industries to the East and South and the entry of producers in the up and coming industrial districts are creating concentrations of specific industries in Rayong, Ayutthaya and Chachoengsao. These could be a source of productivity gains from localization economies.

- The survey findings and evidence emerging from other research also indicate that the industrialization of the Bangkok urban region has not resulted in the formation of industrial clusters that could make a significant difference to productivity, industrial deepening and innovation. The reason seems to be that Bangkok's industries are mainly operating with codified technologies borrowed from abroad and producing mostly standardized items. Their clustering is of a virtual kind. They depend on overseas suppliers (mainly regional ones) of machinery, components and intermediate products and the domestic supply chain and local interdependencies are relatively weak and are of an arm's length nature. The potential exists for a thickening of interdependencies and for cooperative efforts at design, indigenization of component manufacturing, adaptation of technologies and for innovation within true clusters. The high ranking assigned to Thailand's industrial capabilities and its opportunities for diversification by research reported earlier in this study (see Felipe, Abdon and Kumar 2010), suggests that there is accumulating potential ripe for harvesting if the leadership and entrepreneurial resources are forthcoming.

- For Thailand and Bangkok, the challenge is to enhance industrial capabilities in the leading industries by moving up the ladder of technology, through diversification and through a closer integration of manufacturing with services. This process would be expedited by the formation of local clusters which remain 
interlinked with and absorb technology from industries overseas. ${ }^{60}$ In other words, if the current virtual clusters are transformed into hybrids with a substantial local dimension which can feed virtuous spirals of growth fed by productivity in the Bangkok urban region. ${ }^{61}$

- The evidence gathered suggests that industrial change and the harnessing of agglomeration economies in the Bangkok region is being hampered by a number of constraints:

- The quality of the factory labor force.

- The quality and volume of science, engineering and technical skills.

- The physical infrastructure in and around the industrial estates. Clearly also there is room for improving the transport infrastructure connecting production nodes in the urban region ${ }^{62}$ as well as the intra-city network in Bangkok.

- The ICT infrastructure lags behind that of Korea, Taiwan (China) and Singapore.

- Living conditions, services and amenities in the satellite cities do not induce some white collar and skilled workers to shift from Bangkok and help to seed clusters in promising locations close to but outside of Bangkok.

- Research, problem solving and technology development capacity at universities needs strengthening so as to stimulate links with the business sector.

The above leads us to a number of recommendations that could contribute to the competitiveness and growth prospects of industry in the Bangkok region.

- The Bangkok region would benefit from a clearly articulated and forcefully championed medium term development strategy that spells out objectives and indicates how these can be realized with the help of policies that mobilize the existing potential and further enhance its capabilities. A strategy which wins the backing of the key stakeholders, domestic and foreign, would be an important step towards achieving sustainable growth.

- The region should aim to build capabilities in a number of areas -In manufacturing autos, textiles and food processing ${ }^{63}$ are the most promising. In

\footnotetext{
${ }^{60}$ Being able to recruit specialized skills from outside of Thailand would be one advantage, complementing knowledge and technology flow.

${ }^{61}$ Knowledge flows taking the form of "local buzz" and global pipelines bringing knowledge from afar are both essential (Gertler and Wolfe 2004).

${ }^{62}$ Improving the roads so that they could accommodate heavier vehicles would reduce transport costs and traffic accidents.

${ }^{63}$ This portfolio of industries would combine the advantages of innovativeness and stable growth. They would also draw upon the accumulated comparative advantage of the region.
} 
services, logistics, marketing, design and publishing could become important sources of growth and co-create value with manufacturing activities. Their prospects would be enhanced through localized clustering that boosts productivity and innovativeness.

- The future of each of these industries will depend upon technological excellence and innovation. The auto industry will have to find a major regional niche in light trucks, motorbikes, and small cars that are increasingly fuel efficient and the local electronics industry might be oriented to serve the needs of the auto sector. Textiles and garments need to increase competiveness through greater emphasis on new materials serving other sectors, such as automotive, construction and medical services and through better designs. The food industry needs to mobilize the techniques of bioengineering and other disciplines to upgrade the entire supply chain and focus on innovations in products, packaging and marketing. ${ }^{64}$

- Thailand's business climate could be improved. The weaknesses have been documented by the World Bank's Doing Business reports and others on competitiveness and remedies highlighted. Further deterioration would damage the urban region's prospects.

- Localized clustering and innovation are desirable objectives and within reach. They will depend upon three factors, assuming of course that the business climate encourages investment.

- Major local firms - and a pool of smaller firms augmented by start-ups with innovative products or services ${ }^{65}$ - must set the pace and with policy encouragement make technological advances central to their competitiveness. This calls for a significant shift in the strategy and objectives of managements and improved managerial skills. Ultimately it is the management of Thai firms that will determine whether the Bangkok urban region becomes a home to innovative clusters of firms.

- Existing and new firms will need all the help they can get from two sources. ${ }^{66}$ First, perhaps no more than two or three universities in the Bangkok region must achieve levels of excellence in teaching and S\&E research comparable to the best in Asia if not the world. In particular,

\footnotetext{
${ }^{64}$ The success in restoring the health of shrimp fisheries with the assistance of the Kung Krabaen Bay Royal Development Study, shows how research can contribute to sustainable agro-industrial development ("Down on the Shrimp Farm" 2010).

${ }^{65}$ The importance of new high impact firms in boosting growth is noted by Sallet, Paisley and Masterman (2009).

${ }^{66}$ See Gertler and Wolfe (2004) on the contribution of catalytic firms, universities and research centers. Smaller firms which cannot afford to maintain their own research staff are more likely to seek the assistance of a university if one with the expertise is nearby (Power and Lundmark 2004).
} 
they must focus on engineering and bioscience departments that can cater to the needs of the leading industries and become a source of entrepreneurship as well (Audretsch 2008). Efforts by universities, when matched by a change in attitudes of management can together accelerate the tempo of technological change and push Bangkok's industrialization to the next level. ${ }^{67}$ Second, managers and entrepreneurs will need all the help they can obtain from providers of finance, of research, of design and other services. These are adequate but they must become world class.

- Lastly, Bangkok must ensure that public amenities, services, housing and transport and IT infrastructures receive sustained attention and financing. The technology now available to create a "smart" highway system that reduces congestion costs and the IT that can be mobilized for the purposes of connected urban development, would enable Bangkok to augment its industrial capabilities via the clustering of firms but also help it become a greener city (Villa and Mitchell 2009; and Ezell 2010). The quality of life will be vital to retaining a large talent pool, attracting investment and sustaining the tourist industry.

It is not just the livability of Bangkok that is critical, but also the livability and urban attractiveness of the smaller cities in the urban region that are likely to be the nodes for new local industrial clusters. If these cities are to play the roles expected of them, then they too must provide services, amenities and infrastructure sufficient to draw and retain a class of knowledge workers who currently are unwilling to forsake Bangkok. This transformation of secondary cities will require local leadership, ${ }^{68}$ and better planning, governance, financing and effective interjurisdictional coordination.

It is through such a combination of initiatives that Bangkok will become an urban mega region that can sustain rapid growth and compete with other dynamic regions in Asia.

\footnotetext{
${ }^{67}$ Liefner and Schiller (2008) point to the limited capabilities and contribution of Thai universities to date and stress the advantages of greater investment in universities and restructuring of their internal organization. Sohn and Kenney (2007) draw attention to the contribution of Korean universities to technological advancement through high quality training.

${ }^{68}$ Sallet, Paisley and Masterman (2009) highlight the role of local leadership in cluster formation. Webster (2004) notes that many of the industrial estates are located not in municipalities but in Tambon Administrative Organizations which are rural oriented and are the least sophisticated forms of government in Thailand.
} 


\section{References}

Andersen, Poul Houman. 2006. "Regional Clusters in a Global World: Production Relocation, Innovation, and Industrial Decline." California Management Review 49(1):101-122.

Audretsch, David B. 2008. The Entrepreneurial Society. New York: Oxford University Press.

Bloom, Nicholas and John Van Reenen. 2010. "Why Do Management Practices Differ across Firms and Countries." Journal of Economic Perspectives 24(1):203-224.

Brimble, Peter and Richard F. Doner. 2007. "University-Industry Linkages and Economic Development: The Case of Thailand." World Development 35(6):1021-1036.

Cooke, Philip. 2004. "Life Sciences Clusters and Regional Science Policy." Urban Studies 41(5/6):1113-1131.

Deichmann, Uwe, Somik V. Lall, Stephen J. Redding, and Anthony J.Venables. 2008. "Industrial Location in Developing Countries." The World Bank Research Observer 23(2):219-246.

Doner, Richard F. 2009. The Politics of Uneven Development: Thailand's Economic Growth in Comparative Perspective. New York: Cambridge University Press.

"Down on the Shrimp Farm." Science Magazine Vol 328, 18 June 2010.

Drofiak, Alex and Elizabeth Garnsey. 2009. "The Cambridge High Tech Cluster:

Resilience and Response to Cyclical Trends." Centre for Technology Management Working Paper Series 2009/01, Institute for Manufacturing, University of Cambridge, Cambridge.

Ellison, Glenn, Edward L. Glaeser, and William R. Kerr. 2010. "What Causes Industry Agglomeration? Evidence from Coagglomeration Patterns." American Economic Review 100 (June 2010): 1195-1213.

Ezell, Stephen. 2010. "Bringing U.S. Roads into the $21^{\text {st }}$ Century." Issues in Science and Technology. Summer 2010: 77-86.

Felipe, Jesus, Arnelyn Abdon and Utsav Kumar. 2010. "Development and Accumulation of New Capabilities: The Index of Opportunities." VOXEU, 22 July 2010.

Ferrantino, Michael J., Danielle Trachtenberg, and Alison Weingarden. 2010. "Can the US Manufacture Employment Through Exports?" VOXEU, 5 August 2010.

Frug, Gerald E., and David Barron. 2008. City Bound: How States Stifle Urban Innovation. Ithaca, NY: Cornell University Press.

Fung, Victor K., William K. Fung and Yoram Wind. 2008. Competing in a Flat World: Building Enterprises for a Borderless World. Upper Saddle River, NJ: Pearson Education Inc. 
Gertler, Meric S. and David A. Wolfe. 2004. "Clusters from the inside and Out: Local Dynamics and Global Linkages." Urban Studies 41(5/6):1071-1093.

Glaeser, Edward L. 2010. Agglomeration Economics. Chicago, IL: The University of Chicago Press.

Glaeser, Edward L. and Joshua D. Gottlieb. 2009. "The Wealth of Cities: Agglomeration Economies and Spatial Equilibrium in the United States." Journal of Economic Literature 47(4):983-1028.

Henderson, J. Vernon. 2010. "Cities and Development." Journal of Regional Science 50(1): 515-540.

Humphrey, John and Hubert Schmitz. 2002. "How Does Insertion in Global Value Chains Affect Upgrading in Industrial Clusters?" Regional Studies 36(9):1017-1027.

Istrate, Emilia, Jonathan Rothwell, and Bruce Katz. 2010. "Export Nation: How U.S. Metros Lead National Export Growth and Boost Competitiveness." Metropolitan Policy Program at Brookings. Washington, DC: The Brookings Institution.

Jorgenson, Dale W. and Kazuyuki Motohashi. 2005. "Information Technology and the Japanese Economy." Journal of the Japanese and International Economies 19(4):460481.

Jorgenson, Dale.W. 2001. "Information Technology and the Us Economy." American Economic Review 91(1):1-32.

Kenney, Martin and Donald Patton. 2006. "Silicon Valley: Key Features." University of California, Davis, Davis, CA.

Lall, Sanjaya, John Weiss and Jinkang Zhang. 2006. "The "Sophistication" Of Exports: A New Trade Measure." World Development 34(2):222-237.

Leibovitz, Joseph. 2004. "'Embryonic' Knowledge-Based Clusters and Cities: The Case of Biotechnology in Scotland." Urban Studies 41(5/6):1133-1155.

Liefner, Ingo and Daniel Schiller. 2008. "Academic Capabilities in Developing Countries--a Conceptual Framework with Empirical Illustrations from Thailand." Research Policy 37(2):276-293.

Mathews, John A. and Dong Sung Cho. 2000. Tiger Technology: The Creation of a Semiconductor Industry in East Asia. Cambridge Asia-Pacific Studies. Cambridge; New York and Melbourne: Cambridge University Press,.

Neumark, David, and Jed Kolko. 2010. "Do Enterprise Zones Create Jobs? Evidence from California's Enterprise Zone Program." Journal of Urban Economics 68(2010): 119.

OECD. 2001. Innovative Clusters: Drivers of National Innovation Systems. Paris: OECD Publishing.

Porter, Michael. 1998. "Clusters and the New Economics of Competition." Harvard Business Review 76(6):77-90. 
Power, Dominic and Mats Lundmark. 2004. "Working through Knowledge Pools: Labour Market Dynamics, the Transference of Knowledge and Ideas, Adn Industrial Clusters." Urban Studies 41(5/6):1025-1044.

Puga, Deigo. 2010. "The Magnitude and Causes of Agglomeration Economies." Journal of Regional Science 50(1): 203-219.

Rappaport, Jordan and Jeffrey D. Sachs. 2003. "The United States as a Coastal Nation." Journal of Economic Growth 8(1):5-46.

Rodriguez-Clare, Andres. 2007. "Clusters and Comparative Advantage: Implications for Industrial Policy." Journal of Development Economics 82(1):43-57.

Rosenthal, Stuart S. and William C. Strange. 2010. "Small Establishments/Big Effects: Agglomeration, Industrial Organization and Entrepreneurship." In The Economics of Agglomeration, ed. Glaeser, Edward L., Chicago, IL: The University of Chicago Press.

Sallet, Jonathan, Ed Paisley and Justin Masterman. 2009. The Geography of Innovation: The Federal Government and the Growth of Regional Innovation Clusters. Washington, D.C.: Science Progress.

Scott, Allen J. 2001. Global City Regions. Oxford, U.K.: Oxford University Press.

Scott, Allen J. 2008. Social Economy of the Metropolis: Cognitive-Cultural Capitalism and the Global Resurgence of Cities. Oxford, UK: Oxford University Press.

Sohn, Dong-Won and Martin Kenney. 2007. "Universities, Clusters, and Innovation Systems: The Case of Seoul, Korea." World Development 35(6):991-1004.

Steinfield, Charles, Ada Scupola, and Carolina Lopez-Nicolas. 2010. "Social Capital, ICT Use and Company Performance: Findings from the Medicon Valley Biotech Cluster." Technological Forecasting and Social Change 77(7): 1156-1166.

Syverson, Chad. 2010. "What Determines Productivity?" NBER Working Paper Series 15712, National Bureau of Economic Research, Cambridge, MA.

TDRI. 2009. "A Study on the Development of the Urban Area in Bangkok and Surrounding Areas: The Results of Interviews on Industrial Clusters." Thailand Development Research Institute, Bangkok, Thailand.

Toyota Motor Corporation. 2009. "Annual Report." http://www.toyota.co.jp/en/ir/library/annual/pdf/2009/p36.pdf.

Tzeng, Cheng-Hua. 2010. "Managing Innovation for Economic Development in Greater China: The Origins of Hsinchu and Zhongguancun." Technology in Society 32(2010): 110-121.

UN-HABITAT. 2010. State of the World Cities 2010/2011: Cities for All. London: UNHABITAT.

UNCTAD. 2010. World Investment Report 2010: Investing In a Low-Carbon Economy. New York, NY: United Nations.

UNIDO. 2009. Industrial Development Report 2009: Breaking in and Moving Up: New Industrial Challenges for the Bottom Billion and the Middle-Income Countries. Vienna: UNIDO. 
Villa, Nicola, and Shane Mitchell. 2009. "Connecting Cities: Achieving Sustainability Through Innovation." Fifth Urban Research Symposium 2009, Marseilles.

Webster, Douglas. 2004. "Bangkok: Evolution and Adaptation under Stress." In World Cities Beyond the West: Globalization, Development, and Inequality, ed. Gugler, Josef, Cambridge, UK: Cambridge University Press.

World Bank. 2008. Towards a Knowledge Economy in Thailand. Bangkok: World Bank. World Bank. 2008a. Thailand Infrastructure Annual Report 2008. Bangkok: World Bank. World Bank. 2009. Thailand Investment Climate Study Update. Bangkok: World Bank. Yilmaz, Yasim. 2009. "Higher Education Institutions in Thailand and Malaysia: Can They Deliver?" World Bank, Washington, DC.

Yusuf, Shahid and Kaoru Nabeshima. 2009. Tiger Economies under Threat: Comparative Analysis of Malaysia's Industrial Prospects and Policy Options. Washington, DC: World Bank.

---. 2010. Tiger Economies under Threat: A Comparative Analysis of Malaysia's Industrial Prospects and Policy Options. Washington, DC: World Bank.

Yusuf, Shahid, Kaoru Nabeshima and Shoichi Yamashita. 2008. Growing Industrial Clusters in Asia: Serendipity and Science. Washington, DC: World Bank.

Zhou, Yu. 2008. The inside Story of China's High-Tech Industry: Making Silicon Valley in Beijing. New York: Rowman \& Littlefield Publishers. 